\title{
Schoolverlaters tussen onderwijs en arbeidsmarkt 2012
}

Citation for published version (APA):

Meng, C. M., Allen, J. P., Huijgen, T. G., Levels, M., \& Verhagen, A. M. C. (2013). Schoolverlaters tussen onderwijs en arbeidsmarkt 2012. ROA. ROA Reports No. 007 https://doi.org/10.26481/umarep.2013007

Document status and date:

Published: 01/01/2013

DOI:

10.26481/umarep.2013007

Document Version:

Publisher's PDF, also known as Version of record

\section{Please check the document version of this publication:}

- A submitted manuscript is the version of the article upon submission and before peer-review. There can be important differences between the submitted version and the official published version of record.

People interested in the research are advised to contact the author for the final version of the publication, or visit the DOI to the publisher's website.

- The final author version and the galley proof are versions of the publication after peer review.

- The final published version features the final layout of the paper including the volume, issue and page numbers.

Link to publication

\footnotetext{
General rights rights.

- You may freely distribute the URL identifying the publication in the public portal. please follow below link for the End User Agreement:

www.umlib.nl/taverne-license

Take down policy

If you believe that this document breaches copyright please contact us at:

repository@maastrichtuniversity.nl

providing details and we will investigate your claim.
}

Copyright and moral rights for the publications made accessible in the public portal are retained by the authors and/or other copyright owners and it is a condition of accessing publications that users recognise and abide by the legal requirements associated with these

- Users may download and print one copy of any publication from the public portal for the purpose of private study or research.

- You may not further distribute the material or use it for any profit-making activity or commercial gain

If the publication is distributed under the terms of Article $25 \mathrm{fa}$ of the Dutch Copyright Act, indicated by the "Taverne" license above, 


\section{Schoolverlaters tussen onderwijs en arbeidsmarkt 2012}

ROA-R-2013/7

Researchcentrum voor Onderwijs en Arbeidsmarkt

Maastricht University

School of Business and Economics

Maastricht, juli 2013 


\section{Colofon}

(C) Researchcentrum voor Onderwijs en Arbeidsmarkt (ROA). Niets uit deze uitgave mag op enige manier worden verveelvoudigd zonder voorafgaande schriftelijke toestemming van de directeur van het ROA.

\section{Researchcentrum voor Onderwijs en Arbeidsmarkt}

Maastricht University

School of Business and Economics

\section{Vormgeving}

ROA secretariaat, Maastricht

\section{Verkoop}

Researchcentrum voor Onderwijs en Arbeidsmarkt email: secretary-roa-sbe@maastrichtuniversity.nl website: www.roa.nl

ISBN: 978-90-532I-515-9

juli 2013 


\section{Inhoud}

Voorwoord $\quad$ V

SchoolverlatersInformatieSysteem: een openbaar toegankelijke bron van data VII Samenvatting

IX

1 Kwaliteit van gediplomeerde schoolverlaters 1

1.1 Inleiding 1

1.2 Leeswijzer 2

1.3 Opleiding: Kwalificatie 3

1.4 Opleiding: Selectiviteit 9

$\begin{array}{ll}1.5 & \text { Opleiding: Tevredenheid met opleiding } \\ 1.6\end{array}$

$\begin{array}{lll}1.6 & 16\end{array}$

$\begin{array}{lll}1.7 & \text { Vervolgonderwijs: Kwalificerende vervolgtrajecten } & 17\end{array}$

1.8 Vervolgonderwijs: Voorbereiding en aansluiting 20

$\begin{array}{ll}1.9 \text { Vervolgonderwijs: Succes } & 24\end{array}$

1.10 Arbeidsmarkt: Kans op werk 28

1.11 Arbeidsmarkt: Branches en dienstverband 36

1.12 Arbeidsmarkt: Aansluiting tussen werk en opleiding 40

1.13 Arbeidsmarkt: Salaris $\quad 43$

1.14 Tevredenheid met werk $\quad 45$

2 Kwetsbare jongeren op de arbeidsmarkt: lessen van het MBO 47

$\begin{array}{lll}2.1 & \text { Inleiding } & 47\end{array}$

2.2 Arbeidsmarktkansen van gekwalificeerde MBO'ers 48

2.2.1 Kans op werkloosheid 48

2.2.2 Kans om in en positie als NEET terecht te komen 53

2.2.3 Kans op langdurige intredewerkloosheid 55

2.3 Alternatieve strategieën 59

2.3.1 Een baan onder het bereikte opleidingsniveau of buiten het gestudeerde veld 59

2.3.2 Doorstuderen 62

2.4 Verklaringen voor werkloosheid onder MBO'ers na $2008 \quad 64$

2.5 Conclusies 69

3 Een succesvolle arbeidsmarktintrede in crisistijd: lessen van het HBO 71

$\begin{array}{lll}3.1 & \text { Inleiding } & 71\end{array}$

3.2 Effecten van de crisis op de arbeidsmarktintrede van HBO'ers 72

3.3 Crisisbestendige opleidingen 76

3.4 Hebben crisisbestendige opleidingen een matige uitgangspositie? 82

3.5 Wat makt een opleiding crisisbestendig? 84 
3.6 Wat is bepalend voor individueel succes in crisistijd?

3.7 Conclusies

Bijlage 1: Tabellen hoofdstuk 2

Bijlage 2: Tabellen hoofdstuk 3

Bijlage 3: Kernindicatoren

Statistische Bijlage

Tabellen naar opleidingssector 


\section{Voorwoord}

Wat vinden gediplomeerde schoolverlaters van hun opleiding en wat gaan ze na hun opleiding doen? Hoe is de aansluiting met het vervolgonderwijs? En als ze naar de arbeidsmarkt gaan, hoe snel krijgen ze dan werk? En sluit dat werk dan ook aan op de gevolgde opleiding? Wat zijn de consequenties van de recente economische crisis?

Sinds I99I voert het Researchcentrum voor Onderwijs en Arbeidsmarkt (ROA) van Maastricht University in samenwerking met DESAN Research Solutions enkele grootschalige onderzoeken uit onder recente schoolverlaters en pas afgestudeerden waarmee op dit soort vragen een antwoord kan worden gegeven. Het voorliggende rapport Schoolverlaters tussen onderwijs en arbeidsmarkt $20 I 2$ gaat in op de transitie van school naar werk of vervolgonderwijs, die gediplomeerden maken. De resultaten die in dit rapport worden gepresenteerd zijn gebaseerd op het onderzoek dat eind 2012 over bijna de volle breedte van het Nederlandse onderwijsstelsel is uitgevoerd, en hebben betrekking op de situatie van gediplomeerde schoolverlaters (VMBO, AVO en $\mathrm{MBO}$ ) en afgestudeerden (HBO) ongeveer anderhalf jaar na het voltooien van de opleiding. In totaal zijn ruim 75.000 schoolverlaters en afgestudeerden van het schooljaar 20I0-20II benaderd. De totale respons bedroeg $32 \%$. De verzamelde gegevens vormen samen het door het ROA ontwikkelde SchoolverlatersInformatieSysteem (SIS). Dit informatiesysteem is gebaseerd op grootschalige enquêtes die volgens een geïntegreerd model worden uitgevoerd.

Allereerst betreft het de VO-Monitor. Deze enquête is gericht op gediplomeerde schoolverlaters van het algemeen voortgezet onderwijs (HAVO, VWO) en het voorbereidend beroepsonderwijs (VMBO). Daarnaast zijn er de BVE-Monitor, - een enquête onder gediplomeerde schoolverlaters van de beroepsopleidende (BOL) en beroepsbegeleidende leerweg (BBL) van het middelbaar beroepsonderwijs (MBO) - en de HBO-Monitor, een enquête gericht op afgestudeerden van het hoger beroepsonderwijs (HBO). De HBO-Monitor wordt uitgevoerd onder auspiciën van de Vereniging Hogescholen. Tot slot betreft het de VSV-Monitor, een enquête onder voortijdige schoolverlaters. Over de resultaten van de VSV-Monitor verschijnt een apart Factsheet. Het ROA heeft de algehele projectleiding wat deze monitoren betreft en is specifiek verantwoordelijk voor de instrumentontwikkeling en de wetenschappelijk analyse en rapportage. DESAN Research Solutions is verantwoordelijk voor de dataverzameling en - verwerking, alsmede voor de specifieke rapporten voor de deelnemende onderwijsinstellingen.

De projectleiding van Schoolverlaters tussen onderwijs en arbeidsmarkt 2012 berust bij dr. Christoph Meng. De rapportage is geschreven door dr. Jim Allen, drs. Timo Huijgen, dr. Mark Levels, dr. Christoph Meng en drs. Annelore Verhagen. De Statistische Bijlage is 
samengesteld door Paul van der Kolk. Secretariële ondersteuning is verleend door Mariëlle Retz en Esther Soudant. Voornoemde personen zijn allen werkzaam bij het ROA. Aan SIS werken verder mee drs. Monique van Alphen, drs. Han van Dongen en drs. Barbara Kinket (allen werkzaam bij DESAN Research Solutions).

Een speciaal woord van dank gaat uit naar de Dienst Uitvoering Onderwijs voor de medewerking bij het uitzetten van de steekproeven onder de gediplomeerde schoolverlaters van het $\mathrm{VMBO}$, het $\mathrm{MBO}$ en het AVO. Een speciaal woord van dank wordt verder gericht aan de vertegenwoordigers van de financiers die zitting hebben in de klankbordgroep: drs. M. Doll (werkzaam bij het Ministerie van Sociale Zaken en Werkgelegenheid), drs. U. Teunis (werkzaam bij het Ministerie van Economische Zaken), drs. D. van Gessel, dr. P. van Oijen, drs. drs. B. Verlaan en drs. M. Warmerdam (allen werkzaam bij het Ministerie van Onderwijs, Cultuur en Wetenschap) en drs. S.A. van der Wulp (Vereniging Hogescholen).

De subsidiemiddelen maken de basisvoorziening mogelijk (dataverzameling, technisch databeheer, methoden- en modellenstudies) en zijn beschikbaar gesteld door het Ministerie van Onderwijs, Cultuur en Wetenschap, het Ministerie van Economische Zaken en het Ministerie van Sociale Zaken en Werkgelegenheid. Deze basisvoorziening maakt een breed pallet van strategisch onderzoek mogelijk, van proefschriften, wetenschappelijke en beleidsrelevante artikelen tot landelijke beleidsrapportages. Het dankzij de basisvoorziening ontstane databestand geeft daarbij in beginsel de mogelijkheid om de transitie van onderwijs naar vervolgonderwijs/arbeidsmarkt op landelijk niveau in kaart te brengen. Daarnaast biedt de basisvoorziening de startmogelijkheid om op een efficiënte manier uitgebreidere en diepgaandere studies op bijvoorbeeld regionaal, sectoraal of schoolniveau te bewerkstellingen. Regionale overheden of bijvoorbeeld onderwijs overkoepelende organisaties kunnen dankzij deze basisvoorziening op eenvoudige en kostenefficiënte wijze beleidsrelevante informatie verzamelen en tegen het landelijke beeld afzetten. 


\title{
SchoolverlatersInformatieSysteem: een openbaar toegankelijke bron van data
}

\begin{abstract}
Algemeen
De subsidiemiddelen beschikbaar gesteld door het Ministerie van Onderwijs, Cultuur en Wetenschap, het Ministerie van Economische Zaken en het Ministerie van Sociale Zaken en Werkgelegenheid maken de basisvoorziening mogelijk (dataverzameling, technisch databeheer en algemene methoden- en modellenstudies). De databestanden zijn daarbij vrij toegankelijk en maken daarmee een breed pallet van strategisch onderzoek mogelijk, van proefschriften, wetenschappelijke beleidsrelevante artikelen tot landelijke beleidsrapportages. De jaarlijkse databestanden afkomstig van het SchoolverlatersInformatieSysteem zijn beschikbaar via www.dans.knaw.nl. Via het Researchcentrum voor Onderwijs en Arbeidsmarkt kunnen onderzoekers eveneens kosteloos een Engelstalig trendbestand (metingen 1998 - 2012) opvragen. Voor ondersteuning bij het gebruik van de databestanden zijn de onderzoekers van het ROA bereikbaar via secretary-roa-sbe@maastrichtuniversity.nl.
\end{abstract}

Cijfers afkomstig van het SchoolverlatersInformatieSysteem zijn recent onder andere gebruikt voor:

- Studiekeuze I23 website

- Studie in cijfers

- Keuzegids MBO, Keuzegids HBO

- Onderwijsinspectie: De staat van het onderwijs - onderwijsverslag $201 \mathrm{II}-2 \mathrm{OI2}$

- $\mathrm{MBO}$ raad: Feiten en cijfers

- ECBO: Het Nederlandse onderwijs geketend: Doorstroom in en tussen vo en mbo

- ECBO: De kleur van het middelbaar beroepsonderwijs: Een overzichtsstudie naar allochtonen in het mbo

- Inspectie der Rijksfinanciën: Productiviteit Onderwijs, Rapport brede heroverwegingen

- Innovatieplatform: Kennis en Innovatie Agenda 20II - 2020

I. Voor rapportages van het ROA op basis van cijfers afkomstig van het SchoolverlatersInformatieSysteem, zie www.roa.nl. 


\section{Website Kerncijfers Schoolverlatersonderzoeken: www.roa.unimaas.nl/kerncijfers.htm}

Op de website Kerncijfers Schoolverlatersonderzoeken (www.roa.unimaas.nl/kerncijfers.htm) zijn landelijke statistieken te vinden over gediplomeerde schoolverlaters van het initiële onderwijs in Nederland. De cijfers zijn gebaseerd op de schoolverlatersonderzoeken van het ROA en hebben betrekking op de gediplomeerden van het AVO, $\mathrm{VMBO}, \mathrm{MBO}$ en het HO. De kerncijfers die gepresenteerd worden geven een inzicht in de gevolgde studie, het vervolgonderwijs en de intrede van de schoolverlaters op de arbeidsmarkt.

De website is te raadplegen vanuit twee invalshoeken: naar onderwijsindeling en naar kernindicator. De invalshoek naar onderwijs laat alle kerncijfers voor een bepaalde onderwijsindeling zien. Hierbij kan gekozen worden voor onderwijsniveaus, onderwijssectoren en individuele opleidingen. Daarnaast is er de mogelijkheid om een keuze te maken voor voltijd, deeltijd of duale opleidingsvarianten. De invalshoek naar indicator laat voor alle onderwijsniveaus, - sectoren dan wel opleidingen de informatie over één gekozen indicator zien. Zowel in het menu als in de overzichtstabellen zijn de kernindicatoren naar een vijftal categorieën ingedeeld:

- algemene achtergrondkenmerken

- gevolgde opleiding

- oordeel over de gevolgde opleiding

- kenmerken vervolgonderwijs

- arbeidsmarktindicatoren en baankenmerken

De cijfers worden telkens weergegeven voor de laatste vijf meetjaren en worden jaarlijks geupdate rond de tijd dat het landelijk rapport 'Schoolverlaters tussen Onderwijs en Arbeidsmarkt' uitkomt. 


\section{Samenvatting}

\section{Deel 1: Resultaten meting 2012}

Het Researchcentrum voor Onderwijs en Arbeidsmarkt (ROA) verricht jaarlijks onderzoek onder schoolverlaters naar de overgang van school naar vervolgopleiding of arbeidsmarkt. Het voorliggende rapport presenteert de resultaten van de meting die eind 2012 is gehouden onder de gediplomeerde schoolverlaters van het schooljaar 20IO/2OII, dat wil zeggen ongeveer anderhalf jaar na het voltooien van de opleiding. ${ }^{2}$ De resultaten hebben betrekking op nagenoeg de volle breedte van het onderwijs: VMBO, MBO-BOL, MBO-BBL, HAVO, VWO en HBO. ${ }^{3}$ In 2012 is door de VSNU geen meting onder de universitair afgestudeerden gehouden. Er kunnen daardoor geen resultaten voor deze groep gepresenteerd worden. In totaal zijn ruim 75.000 gediplomeerde schoolverlaters en afgestudeerden benaderd. De totale respons bedroeg $32 \%$.

\section{Hoofdstuk 1: Kwaliteit van gediplomeerde schoolverlaters}

Hoofdstuk I gaat in op de vraag hoe het de gediplomeerden en afgestudeerden is vergaan nadat ze de opleiding in 20 II hebben verlaten. In hoofdlijnen omvat het hoofdstuk achtereenvolgens een discussie van a) het oordeel van de gediplomeerden over de gevolgde opleiding, b) de voorbereiding op en het succes in de vervolgopleiding en c) de voorbereiding op en het succes tijdens de arbeidsmarktintrede.

2. In het kader van het onderzoek onder schoolverlaters is in het najaar van 2012 eveneens een enquête gehouden onder leerlingen die in het schooljaar 20IO-20II zonder diploma hun opleiding in het voortgezet onderwijs (VMBO, HAVO of VWO) of in het MBO hebben verlaten zonder in het bezit te zijn van een startkwalificatie. Over het onderzoek onder deze groep ongediplomeerde voortijdige schoolverlaters wordt apart in het Factsheet Voortijdige schoolverlaters 2012 (ROA-F-2013/3) gerapporteerd.

3. Tenzij anders vermeld hebben de resultaten over het $\mathrm{HBO}$ alleen betrekking op afgestudeerden van voltijd opleidingen. 
Tabel S.1

Enkele kernindicatoren

\begin{tabular}{|c|c|c|c|c|c|}
\hline & $\begin{array}{r}\text { Verder leren } \\
\%\end{array}$ & $\begin{array}{r}\text { Zelfde opleiding } \\
\%\end{array}$ & $\begin{array}{r}\text { Werkloosheid } \\
\%\end{array}$ & $\begin{array}{r}\text { Eigen niveau } \\
\%\end{array}$ & $\begin{array}{r}\text { Eigen domein } \\
\%\end{array}$ \\
\hline AVO & 87 & 97 & 27 & $X$ & $X$ \\
\hline VMBO & 98 & 87 & 15 & 82 & 61 \\
\hline BOL 1 & 74 & 80 & 30 & 81 & 67 \\
\hline BOL 2 & 59 & 77 & 19 & 69 & 62 \\
\hline BOL 3 & 45 & 76 & 15 & 70 & 73 \\
\hline BOL 4 & 58 & 77 & 11 & 80 & 74 \\
\hline BBL 1 & 20 & 83 & 5 & 44 & 46 \\
\hline BBL 2 & 29 & 85 & 4 & 69 & 73 \\
\hline BBL 3 & 18 & 84 & 2 & 67 & 85 \\
\hline BBL 4 & 19 & 86 & 2 & 83 & 90 \\
\hline HBO & 31 & 79 & 9 & 77 & 78 \\
\hline wo & $X$ & $X$ & $x$ & $X$ & $X$ \\
\hline
\end{tabular}

$X=$ Vraag niet opgenomen/niet vergelijkbaar; Verder leren $=\%$ respondenten dat een vervolgopleiding is gaan volgen; Zelfde opleiding $=\%$ van de schoolverlaters dat, achteraf bezien, opnieuw dezelfde opleiding zou kiezen; Werkloosheid = Werkzoekenden als \% van de schoolverlaters die zich op de arbeidsmarkt aanbieden; Eigen niveau = $\%$ van de werkende schoolverlaters dat aangeeft dat de werkgever voor deze functie minimaal een diploma van het gevolgde onderwijsniveau vereist; Eigen domein $=\%$ van de werkende schoolverlaters dat aangeeft dat de werkgever voor deze functie een diploma van de gevolgde opleidingsrichting of een verwante opleidingsrichting vereist.

De belangrijkste conclusies zijn:

\section{a) Oordelen over gevolgde opleiding}

- Voorbereiding op arbeidsmarkt wederom kritisch beoordeeld: De aanhoudende economische crisis laat wederom haar sporen na in de beoordeling van de gediplomeerden wat de basis betreft die de opleiding heeft geboden om te starten op de arbeidsmarkt. Slechts 39\% van de gediplomeerde uitstroom vindt dat de opleiding een goede basis heeft geboden om te starten op de arbeidsmarkt ( $26 \%$ is het hier helemaal niet mee eens). Alleen bij de gediplomeerden van het $\mathrm{MBO}-\mathrm{BBL}$ niveau 3 (56\%) en MBO-BBL niveau 4 (6I\%) oordeelt een kleine meerderheid positief.

- Relatief goede voorbereiding op verder leren komt onder druk te staan: $57 \%$ van de gediplomeerde uitstroom vindt dat de gevolgde opleiding een goede basis bood om kennis en vaardigheden verder te ontwikkelen. In de afgelopen jaren stijgt echter het percentage van de gediplomeerde uitstroom dat het hier (helemaal) niet mee eens is op alle onderscheiden onderwijsniveaus.

- Onderwijs wordt pittiger, MBO blijft achter: Het percentage gediplomeerde uitstroom dat de opleidingen niet selectief genoeg heeft ervaren laat een dalende trend zien (VMBO, AVO en $\mathrm{HBO}$ ). Het $\mathrm{MBO}$, en dan vooral het $\mathrm{MBO}-\mathrm{BOL}$, lijkt achter te blijven als het om deze trend gaat.

- Grote meerderheid zou zelfde keuze maken: $85 \%$ van de gediplomeerde uitstroom zou achteraf bezien opnieuw voor dezelfde opleiding kiezen.

b) Vervolgonderwijs (gediplomeerden van het VMBO, AVO en $\mathrm{MBO}$ )

- Voorbereiding op vervolgonderwijs, VMBO loopt achter: acht op de tien gediplomeerden van het HAVO en het VWO is tevreden met de voorbereiding. Onder de gediplomeerden van het $\mathrm{VMBO}$ is dit slechts $5 \mathrm{I} \%$. 
- Aansluiting met vervolgonderwijs goed, overgang naar $\mathrm{HBO}$ meest kritisch beoordeeld: op alle niveaus geldt dat ten minste $60 \%$ de aansluiting met de vervolgopleiding minimaal als voldoende typeert. Met uitzondering van de gediplomeerden van het $\mathrm{HAVO}$ en $\mathrm{MBO}$ niveau 4 (doorstroom naar $\mathrm{HBO}$ ) vermeldt daarbij minimaal $35 \%$ zelfs een goede aansluiting.

\section{c) Arbeidsmarkt}

- Werkloosheid MBO-BOL en HBO loopt verder op: I4\% van de gediplomeerden van het $\mathrm{MBO}-\mathrm{BOL}$, en $9 \%$ van de afgestudeerden van het $\mathrm{HBO}$ (voltijdopleidingen) is op het moment van enquête werkloos. In 2008 was dit nog $5 \%$, respectievelijk $4 \%$.

- MBO-BBL minst geraakt door economische crisis: $3 \%$ van de gediplomeerden van het MBO-BBL is op moment van enquête werkloos. De werkloosheid is daarmee sinds 2009 relatief constant.

\section{Deel 2: Over kwetsbare jongeren en crisistijgers}

De stand van de conjunctuur is bepalend voor de arbeidsmarktdeelname onder de potentiële beroepsbevolking. Dit geldt in het bijzonder voor jongeren (die nog geen gevestigde plaats op de arbeidsmarkt hebben verworven en als eerste worden ontslagen indien het bedrijf waarvoor zij werken het moeilijk krijgt) en voor schoolverlaters (die moeilijker aan hun eerste baan kunnen komen). Het verband tussen conjunctuur en werkloosheid onder recent gediplomeerden en afgestudeerden is goed zichtbaar in Figuur S.I.

\section{Figuur S.1}

Werkloosheid onder afgestudeerden in vier perioden (anderhalf jaar na het behalen van het diploma)

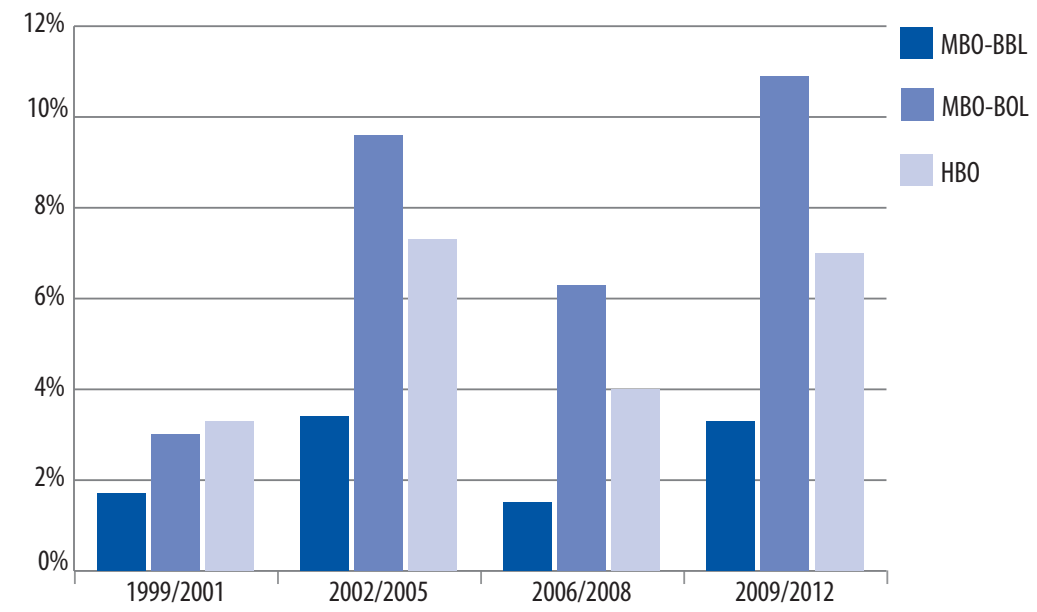

Bron: ROA (SIS), 1999-2012 
De twee economisch goede periodes (1999-200I en 2006-2008) kennen een relatief lage werkloosheid onder de recent gediplomeerden en afgestudeerden. De twee economisch minder goede periodes (2002-2005 en 2009-20I2) kennen een relatief hoge werkloosheid. Wat de huidige periode betreft dient daarbij rekening mee gehouden te worden dat er nog geen licht aan het einde van de tunnel zichtbaar is en, zeker wat 2013 betreft, we met een verder oplopend werkloosheidspercentage rekening dienen te houden.

Hoewel een economische crisis gevolgen heeft over de volle breedte van de arbeidsmarkt, wordt niet iedereen even zwaar getroffen. In hoofdstuk 2 en hoofdstuk 3 trachten we dan ook op een exploratieve wijze nader op de vraag in te gaan wie tot de groep van de meest kwetsbare jongeren en wie tot de crisistijgers behoort.

\section{Hoofdstuk 2: Kwetsbare jongeren op de arbeidsmarkt: lessen van het MBO}

In Hoofdstuk 2 onderzoeken we de gevolgen van de recente economische crisis voor het arbeidsmarktsucces van middelbaar opgeleide gediplomeerden met een startkwalificatie. Het hoofdstuk onderzoekt welke MBO-gediplomeerden het meest kwetsbaar zijn op de arbeidsmarkt, en welke MBO-gediplomeerden kwetsbaarder zijn geworden tijdens de crisis. Daarbij worden verschillen tussen de drie arbeidsmarkt kwalificerende opleidingsniveaus, de gekozen leerwegen en de opleidingssectoren blootgelegd. Ook laten we zien dat MBO'ers in het licht van hun kansen op de arbeidsmarkt kiezen voor alternatieve strategieën, en onderzoeken we of en in welke mate persoonlijke kenmerken van schoolverlaters bepalend zijn voor het hun kansen op de arbeidsmarkt. De belangrijkste conclusies van dit hoofdstuk zijn:

- Schoolverlaters van opleidingen uit MBO-BOL hebben structureel slechtere arbeidsmarktkansen dan gediplomeerden van de MBO-BBL: ze zijn vaker werkloos of $\mathrm{NEET}^{4}$, hebben een grotere kans op een langdurige intredewerkloosheid, moeten vaker een baan onder hun niveau of buiten hun studierichting aannemen, en ze moeten vaker hun arbeidsmarkttransitie uitstellen. Verschillen kunnen slechts zeer beperkt worden verklaard door kenmerken van individuen en opleidingsrichtingen. Dat roept vragen op over de mate waarin de Beroepsopleidende Leerweg MBO'ers goed voorbereidt op de huidige arbeidsmarkt.

- Afgestudeerden in de sector Gezondheidszorg doen het over het algemeen goed. Wellicht verrassend lijkt dat niet te gelden voor alle afgestudeerden uit de sector Techniek. Waar technisch geschoolden het over het algemeen goed doen, geven de analyses aanleiding voor de veronderstelling dat de arbeidsmarktkansen van afgestudeerden uit de sector Techniek op de lagere BOL-niveaus sterk verslechterd zijn.

- Excellente prestaties in het MBO worden niet beloond op de arbeidsmarkt, maar ondermaatse prestaties hangen wel samen met lagere arbeidsmarktkansen.

\section{Hoofdstuk 3: Een succesvolle arbeidsmarktintrede in crisistijd: lessen van het $H B O$}

In hoofdstuk 3 zoeken we naar kenmerken van crisisbestendige opleidingen en afgestudeerden van het HBO. De focus ligt hierbij vooral op relatief succes in crisistijden,

4. NEET $=$ Not Employed, in Education or Training. 
dat wil zeggen, een mate van succes dat vergelijkbaar is met wat wordt bereikt door afgestudeerden van dezelfde opleidingen in economisch betere tijden. We kijken hierbij niet alleen naar de kans op werk, maar ook naar een aantal indicatoren van baankwaliteit: uurloon, werkzekerheid en de kans op werk binnen het eigen kerndomein. Uit de analyses komen onder andere de volgende punten naar voren:

- Het lijkt alsof er bij sommige opleidingen sprake is van een trade-off tussen de kans op werk en baankwaliteit. Afgestudeerden van sommige opleidingen lijken het behoud van baankwaliteit dusdanig belangrijk te hebben gevonden dat ze bereid zijn geweest een verslechtering te accepteren in hun kans op werk, terwijl afgestudeerden van andere opleidingen zich juist bereid hebben getoond om in termen van baankwaliteit een stap terug te aanvaarden ter wille van het behoud van hun kans op werk.

- Opleidingen die succesvol zijn tijdens een crisis zijn als echte "crisistijgers" te bestempelen: opleidingen die zich in economisch goede tijden niet of nauwelijks van andere opleidingen onderscheiden, maar die tijdens de crisis veel beter in staat zijn gebleken hun arbeidsmarktpositie te behouden dan andere opleidingen.

- Hoewel in veel opzichten de typische "mannensectoren" zoals HEO (Hoger Economisch Beroepsonderwijs) en HTO (Hoger Technisch Beroepsonderwijs) veel last hebben gehad van de crisis, blijkt dat nadat we voor geslacht hebben gecontroleerd, opleidingen met relatief veel vrouwen juist minder goed door de crisis zijn gekomen. Verder blijken opleidingen die door hun afgestudeerden als relatief selectief en/of goed worden beoordeeld in termen van voorbereiding op beroepspraktijk, goed door de crisis zijn gekomen.

- Op individueel niveau valt op dat kenmerken waarvan gedacht wordt dat ze met het menselijk kapitaal van afgestudeerden samenhangen, zoals verschillende soorten ervaring, gemiddeld eindcijfer, en na-/bijscholing, een positief effect hebben op arbeidsmarktuitkomsten in crisistijd. In sommige gevallen lijken deze effecten sterker te werken voor afgestudeerden van crisisbestendige opleidingen, terwijl het soms juist afgestudeerden van niet-crisisbestendige opleidingen zijn die hier het meest profijt van hebben, maar over de hele linie lijkt het meer om algemene effecten te gaan die voor iedereen gunstig uitpakten.

- Kenmerken met een negatief effect op arbeidsmarktuitkomsten zijn daarentegen meestal persoons-, onderwijs- en bedrijfskenmerken, zoals geslacht, etniciteit, vooropleiding, studieregio, en bedrijfsgrootte. 



\section{Kwaliteit van gediplomeerde schoolverlaters}

\section{$1.1 \quad$ Inleiding}

Hoe kijken de gediplomeerde schoolverlaters ${ }^{5}$ en de afgestudeerden van het hoger onderwijs terug op de opleiding die zij in het schooljaar 20I0-20II hebben afgerond? Wat zijn ze aansluitend aan de opleiding gaan doen? Hoe is de aansluiting met het vervolgonderwijs? En als ze zich op de arbeidsmarkt aanbieden, hoe snel krijgen ze dan werk en hoe sluit het werk bij de gevolgde opleiding aan? Welke rol speelt de huidige economische crisis hierin? In dit hoofdstuk wordt ingegaan op bovenstaande vragen op basis van de schoolverlaters- en afgestudeerdenonderzoeken die in het najaar van 2012 hebben plaatsgevonden. Daarnaast wordt, waar van belang, een link gelegd met eerdere onderzoeken onder schoolverlaters en afgestudeerden. Het hoofdstuk is daarbij in drie delen onderverdeeld.

\section{Box B.1}

Diploma in crisistijd

Het onderzoek onder de gediplomeerde schoolverlaters en afgestudeerden vond in het najaar van 2012 in een uitzonderlijk economische context plaats. Voor het vierde jaar op rij kende Nederland lage en deels zelfs negatieve economische groeicijfers. Deze aanhoudende economische crisis heeft dan ook zijn neerslag in de hier gepresenteerde cijfers. Dit geldt niet alleen voor de indicatoren rechtstreeks gerelateerd aan de arbeidsmarktintrede (bijvoorbeeld werkloosheid of werkzekerheid) maar dit kan ook van invloed zijn op de manier waarop jongeren de afgeronde opleiding beoordelen. De lezer dient hier rekening mee te houden.

In het eerste gedeelte (paragraaf I.3 tot en met paragraaf I.6) staat de tevredenheid van de gediplomeerde schoolverlaters en de afgestudeerden met betrekking tot de gevolgde opleiding centraal. Achtereenvolgens komt in dit onderdeel aan bod hoe de jongeren denken over de evenwichtigheid van de opleiding met betrekking tot breedte en diepgang, de voorbereiding op de arbeidsloopbaan (startbekwaamheid en ontwikkelpotentieel), de selectiviteit van de gevolgde opleiding en de tevredenheid met andere aspecten van de opleiding zoals de studievoorlichting, de begeleiding of de kwaliteit van de docenten. Tot slot van dit eerste gedeelte wordt de vraag gesteld of de gediplomeerde schoolverlaters en afgestudeerden achteraf bezien dezelfde opleiding wederom zouden kiezen.

5. Gediplomeerde schoolverlaters worden in dit hoofdstuk gedefinieerd als schoolverlaters die in het schooljaar 20I0-20II hun diploma hebben behaald. Hierbij speelt het geen rol of dit diploma het predicaat "startkwalificatie" in de zin van een diploma op minimaal MBO niveau 2 heeft of niet. 
Jongeren die een diploma in het onderwijs hebben behaald staan voor een belangrijke keuze: bieden zij zich aan op de arbeidsmarkt of vervolgen zij hun onderwijscarrière? In het tweede gedeelte van dit hoofdstuk (paragraaf I.7 tot en met paragraaf I.9) staan de gediplomeerden centraal die voor de tweede optie hebben gekozen. We bespreken welk deel van hen voor een vervolgstudie heeft gekozen, welk type vervolgonderwijs zij zijn gaan volgen en hoe succesvol zij in het vervolgonderwijs zijn. Een belangrijk onderdeel van de voorbereiding spelen de informatiebronnen die geraadpleegd worden bij de keuze voor een bepaalde vervolgopleiding. We staan stil bij deze informatiebronnen en analyseren in hoeverre zij in relatie staan met het succes in de vervolgopleiding.

In paragraaf I.IO tot en met paragraaf I.I4 staan we stil bij de transitie tussen onderwijs en arbeidsmarkt. Hier worden aspecten belicht als de werkloosheid onder de gediplomeerde schoolverlaters en afgestudeerden, hun zoekduur tot de eerste baan, de aansluiting qua niveau en richting tussen opleiding en baan, type dienstverband en het werken in deeltijd, de tevredenheid met de baan alsook de verwachtingen van jongeren over de carrièreperspectieven in hun huidige functie.

\subsection{Leeswijzer}

De hoofdbron van de gepresenteerde cijfers in dit hoofdstuk zijn de schoolverlaters- en afgestudeerdenonderzoeken die in het najaar van 2012 hebben plaatsgevonden. Deze betreffen jongeren die in het school-/studiejaar 20I0-20II een diploma van het VMBO, HAVO, VWO, MBO of HBO hebben behaald. Tenzij anders vermeld hebben de cijfers over de afgestudeerden alleen betrekking op de afgestudeerden van voltijd opleidingen. De onderzoeken onder de gediplomeerden/afgestudeerden van het VMBO, HAVO, VWO, MBO en $\mathrm{HBO}$ zijn door het Researchcentrum voor Onderwijs en Arbeidsmarkt (ROA) in het kader van het project SchoolverlatersInformatieSysteem (SIS) uitgevoerd. ${ }^{6}$

Tabel I.I laat per onderwijstype het aantal benaderde schoolverlaters/afgestudeerden, het responspercentage, het aantal respondenten en het gewogen aantal zien. Het gewogen aantal ontstaat door het aantal respondenten a) te wegen en b) op te hogen. De weging is gebaseerd op responsverschillen tussen onder andere opleiding, opleidingsniveau, regio en geslacht. De ophoging is gebaseerd op het aantal gediplomeerden/afgestudeerden van de opleiding in het desbetreffende studiejaar. Een gedetailleerd overzicht op opleidingssector over de aantallen en de respons staat in tabel I van Statistische Bijlage. ${ }^{7}$

6. Zie voor de kerncijfers van ROA's schoolverlatersonderzoeken ook www.roa.unimaas.nl/kerncijfers.htm

7. Voor een uitgebreidere onderbouwing van het onderzoek (steekproeven, manier van benaderen, respons, weging etc.) zie ook www.roa.unimaas.nl/kerncijfers.htm. 
Tabel 1.1

Schoolverlaters- en afgestudeerdenonderzoeken 2012

\begin{tabular}{|l|r|r|r|r|}
\hline Onderwijstype & Benaderde aantallen & Responspercentage & Aantal respondenten & Gewogen aantal \\
\hline HAVO & 1.850 & 36 & 670 & 42.467 \\
\hline VW0 & 1.145 & 42 & 479 & 32.676 \\
\hline VMBO & 7.264 & 27 & 1.951 & 88.734 \\
\hline MBO-BOL & 16.464 & 23 & 3.805 & 91.667 \\
\hline MBO-BBL & 7.372 & 19 & 1.361 & 62.833 \\
\hline HBO (voltijd) & 41.418 & 38 & 15.313 & 49.090 \\
\hline
\end{tabular}

Tenzij anders vermeld worden in dit hoofdstuk altijd resultaten op basis van de gewogen aantallen gepresenteerd. De cijfers waar dit hoofdstuk op is gebaseerd zijn in meer gedetailleerde vorm terug te vinden in de Statistische Bijlage behorende bij dit rapport.

\subsection{Opleiding: Kwalificatie}

Voor het succesvol betreden van de arbeidsmarkt of het succesvol volgen van een vervolgopleiding is het noodzakelijk dat schoolverlaters beschikken over de juiste competenties. In deze paragraaf wordt uiteengezet in hoeverre het onderwijs er in is geslaagd om de schoolverlaters die in het schooljaar 20IO-20II zijn afgestudeerd de benodigde competenties bij te brengen, en hoe deze resultaten zich verhouden tot de resultaten van eerdere meetjaren. Om hier inzicht in te krijgen is aan de schoolverlaters gevraagd de afgeronde opleiding te beoordelen op de volgende aspecten: I) de breedte en diepgang van de opleiding, 2) de mate waarin de opleiding een goede basis heeft geboden om te starten op de arbeidsmarkt en om kennis en vaardigheden verder te ontwikkelen.

Voor zowel het vervolgonderwijs als de arbeidsmarktintrede is het van belang dat de schoolverlaters niet alleen over de juiste competenties beschikken maar ook over het juiste competentieniveau. Het onderwijs doet er met andere woorden geen goed aan indien men leerlingen te weinig vaardigheden aanleert, dat wil zeggen te smal van opzet is, of leerlingen te veel niet relevante vaardigheden aanleert, dat wil zeggen te breed van opzet is. ${ }^{8}$ Daarnaast dient ook het niveau van de aangeleerde kennis en vaardigheden toegesneden te zijn op de eisen zoals die door de arbeidsmarkt en het vervolgonderwijs aan de gediplomeerden gesteld zullen worden dus ook de diepgang van de opleiding is van belang. Tabel I.2 laat het oordeel van de schoolverlaters zien op de aspecten breedte en diepte van de gevolgde opleiding. Van de gediplomeerden en afgestudeerden van alle onderscheiden onderwijsniveaus vindt $7 \%$ dat de opleiding te smal was en $10 \%$ dat de opleiding te breed was. Binnen het $\mathrm{MBO}-\mathrm{BOL}$ is wat deze twee aspecten betreft weinig verschil te zien tussen de twee leerwegen en de vier onderscheiden opleidingsniveaus. Een nadere analyse (zie voor onderliggende cijfers tabel 4 in de statistische bijlage) laat zien dat dit ook in de regel geldt voor de afzonderlijke onderwijssectoren. Uitzonderingen zijn

8. Wat de effecten van een te smalle dan wel een te brede opleiding op een succesvolle intrede op de arbeidsmarkt zijn wordt in hoofdstuk 2 voor het $\mathrm{MBO}$ en in hoofdstuk 3 voor het $\mathrm{HBO}$ nader geanalyseerd. 
daarbij opleidingen in de sector Landbouw en Economie op MBO-BBL niveau 3 die door zo'n I7\% á I $8 \%$ van de gediplomeerden als te smal getypeerd worden en opleidingen in de sector Gezondheidszorg op MBO-BBL niveau 4 die door I6\% als te breed ervaren zijn.

Het percentage afgestudeerden van $\mathrm{HBO}$ voltijdopleidingen die de opleiding als te smal typeert is met $4 \%$ uitermate laag te noemen. Dit in tegenstelling tot het feit dat bijna een op de vier $(22 \%)$ de gevolgde opleiding als te breed heeft ervaren. Met uitzondering van de opleidingen in de $\mathrm{HBO}$-sector Onderwijs ( $7 \%$ vindt deze te breed) en de opleidingen in de sector Gezondheidszorg ( $15 \%$ ) worden alle $\mathrm{HBO}$-onderwijssectoren door minimaal $20 \%$ van de afgestudeerden als te breed ervaren hetgeen betekent dat één op de vijf afgestudeerden niet tevreden is over dit aspect van hun gevolgde $\mathrm{HBO}$ studie.

Figuur I.I laat tot slot de ontwikkeling sinds 2007 zien wat het aspect 'opleiding te breed' betreft. Voor de opleidingen in het AVO, het VMBO en het $\mathrm{MBO}$ geldt dat het resultaat met betrekking tot dit oordeel over de afgelopen vijf metingen uiterst stabiel is. Voor de opleidingen in het $\mathrm{HBO}$ zien we in de periode 2007 (19\%) tot en met 2009 (24\%) een (lichte) stijging van het aandeel dat de opleiding als te breed heeft ervaren en sindsdien een lichte daling. Ook deze figuur laat echter zien dat de ontevredenheid onder de HBO afgestudeerden op dit onderdeel duidelijk groter is dan bij de gediplomeerden van de lagere onderwijsniveaus.

Tabel 1.2

Oordeel over breedte en diepgang van opleiding (\%)

\begin{tabular}{|c|c|c|c|}
\hline & \multicolumn{2}{|c|}{ Breedte } & \multirow{2}{*}{$\begin{array}{c}\text { Diepgang } \\
\text { Te weinig diepgang }\end{array}$} \\
\hline & Te smal & Te breed & \\
\hline HAVO & 3 & 6 & 8 \\
\hline vwo & 2 & 9 & 8 \\
\hline VMBO & 8 & 8 & 9 \\
\hline MBO-BOL 1 & 8 & 8 & 8 \\
\hline MBO-BOL 2 & 9 & 9 & 12 \\
\hline MBO-BOL 3 & 11 & 8 & 17 \\
\hline MBO-BOL 4 & 9 & 10 & 21 \\
\hline MBO-BBL 1 & 11 & 13 & 9 \\
\hline MBO-BBL 2 & 8 & 8 & 13 \\
\hline MBO-BBL 3 & 7 & 8 & 13 \\
\hline MBO-BBL 4 & 4 & 11 & 18 \\
\hline HBO & 4 & 22 & 18 \\
\hline Totaal & 7 & 10 & 13 \\
\hline
\end{tabular}

Zie voor de onderliggende cijfers per opleidingssector tabel 4 in de Statistische Bijlage 
Naast het oordeel over de breedte van de opleiding, laat tabel I.2 ook het oordeel over de diepgang van de gevolgde opleiding zien. Over alle onderwijsniveaus samen vindt $13 \%$ dat de opleiding te weinig diepgang bood. Algemeen geldt daarbij dat met toenemend onderwijsniveau de respondenten kritischer worden wat de diepgang betreft. Binnen het MBO-BOL stijgt het percentage bijvoorbeeld van $8 \%$ (niveau I) naar $21 \%$ (niveau 4). Een relatief vergelijkbaar resultaat zien we voor het $\mathrm{MBO}-\mathrm{BBL}$ en van de afgestudeerden van het $\mathrm{HBO}$ miste I8\% voldoende diepgang binnen de opleiding. Terwijl in het HBO bij een nadere analyse geen grote verschillen tussen de onderwijssectoren te vinden zijn, doen zich in het $\mathrm{MBO}$ een aantal duidelijke verschillen voor. Zo zien we bijvoorbeeld dat de opleidingen in de sectoren Techniek en Economie op MBO-BBL niveau 4 door minder dan $10 \%$ als opleidingen met te weinig diepgang worden ervaren, terwijl dit bij de sector Gezondheidszorg op MBO-BBL niveau 4 door $22 \%$ van de gediplomeerden ervaren is.

Figuur 1.1

Oordeel over de breedte van opleidingen, 2007-2012

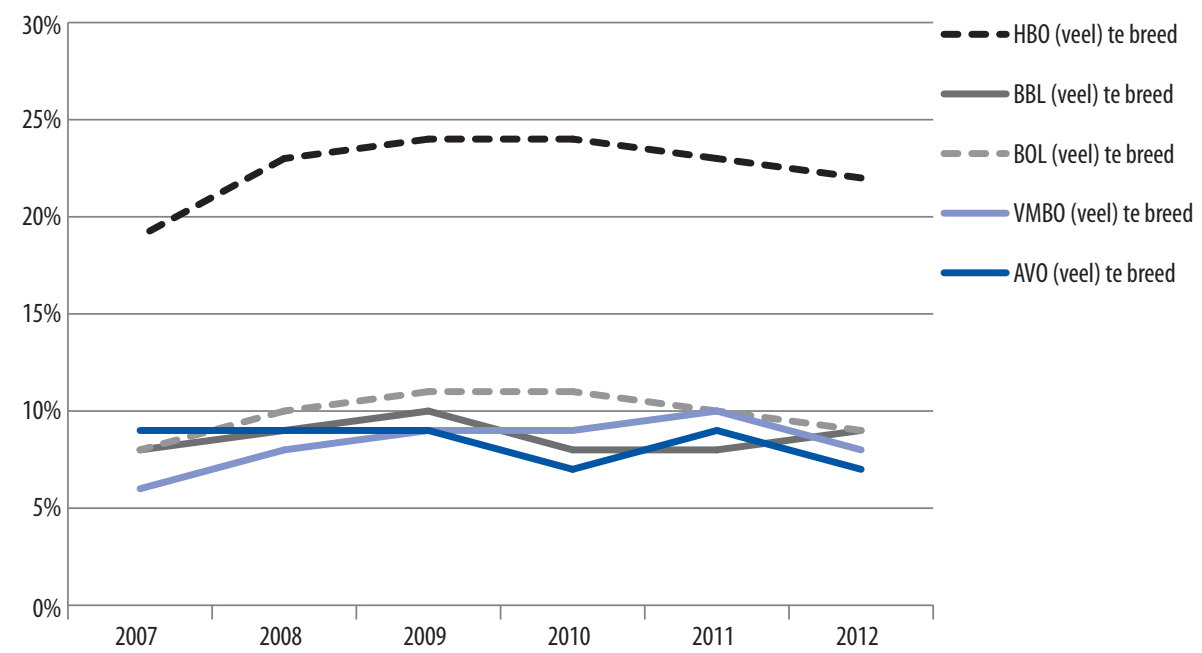

Voorbereiding op de arbeidsloopbaan: startbekwaamheid en ontwikkelpotentieel

Beroepsopleidingen in het $\mathrm{MBO}$ en het $\mathrm{HBO}$ dienen jongeren rechtstreeks voor te bereiden op de arbeidsmarkt en hen wat dit betreft startbekwaam te maken. In eerste instantie lijkt dit niet direct een centrale opdracht van het VMBO, aangezien een diploma van het VMBO niet als startkwalificatie gezien wordt. Echter, gegeven het feit dat een aanzienlijk deel van de gediplomeerden van het VMBO (zie hiervoor paragraaf I.6) zijn onderwijscarrière in de beroepsbegeleidende leerweg (BBL) van het $\mathrm{MBO}$ voortzet, dient ook het $\mathrm{VMBO}$ een goede basis voor een start op de arbeidsmarkt te bieden. Leerlingen in het MBO-BBL zijn immers in de regel vier dagen per week werkzaam en één dag per week op school. 
Tabel 1.3

Opleiding als voorbereiding op de arbeidsloopbaan (\%)

\begin{tabular}{|c|c|c|c|c|}
\hline & \multicolumn{2}{|c|}{ Starten op de arbeidsmarkt } & \multicolumn{2}{|c|}{ Verder ontwikkelen kennis en vaardigheden } \\
\hline & $\begin{array}{c}\text { (Helemaal) geen } \\
\text { goede basis }\end{array}$ & $\begin{array}{c}\text { (Heel) } \\
\text { goede basis }\end{array}$ & $\begin{array}{c}\text { (Helemaal) geen } \\
\text { goede basis }\end{array}$ & $\begin{array}{c}\text { (Heel) } \\
\text { goede basis }\end{array}$ \\
\hline VMBO & 39 & 25 & 11 & 55 \\
\hline MBO-BOL 1 & 21 & 35 & 8 & 45 \\
\hline MBO-BOL 2 & 20 & 40 & 10 & 57 \\
\hline MBO-BOL 3 & 21 & 46 & 12 & 55 \\
\hline MBO-BOL 4 & 26 & 40 & 14 & 55 \\
\hline MBO-BBL 1 & 25 & 30 & 18 & 40 \\
\hline MBO-BBL 2 & 16 & 45 & 11 & 54 \\
\hline MBO-BBL 3 & 11 & 56 & 7 & 64 \\
\hline MBO-BBL 4 & 10 & 61 & 4 & 70 \\
\hline HBO & 22 & 48 & 9 & 63 \\
\hline Totaal & 26 & 39 & 11 & 57 \\
\hline
\end{tabular}

Zie voor de onderliggende cijfers per opleidingssector tabel 5 in de Statistische Bijlage

Tabel I.3 laat in eerste instantie het percentage gediplomeerden zien dat van mening is dat gevolgde opleiding a) (helemaal) geen goede basis bood en b) een (heel) goede basis bood om te starten op de arbeidsmarkt. Van alle ondervraagde jongeren vindt slechts $39 \%$ dat de opleiding een (heel) goede basis bood. Niet verrassend scoren de opleidingen in het VMBO op dit onderdeel het minst goed. Van de gediplomeerden van het MBO niveau I (opleidingen die formeel geen startkwalificatie bieden) is tussen de $30 \%$ (BBL) en $35 \%$ (BOL) van mening dat de opleiding een goede basis bood om te starten op de arbeidsmarkt. Terwijl op dit niveau de beroepsbegeleidende leerweg slechter scoort, geldt voor de drie andere $\mathrm{MBO}$ niveaus dat de opleidingen in het $\mathrm{MBO}-\mathrm{BOL}$ relatief minder goed beoordeeld worden. Het meest duidelijk komt dit op de niveaus 3 en 4 naar voren waar gemiddeld tussen de $40 \%$ en $46 \%$ van de gediplomeerden van het MBO-BOL vindt dat de opleiding een (heel) goede basis bood terwijl dit onder de gediplomeerden van het MBO-BBL gemiddeld op niveau $356 \%$ en op niveau 4 zelfs $61 \%$ is. Nadere analyses laten zien dat de economische crisis daarbij duidelijk zijn neerslag heeft op het oordeel van de gediplomeerden en afgestudeerden wat de basis betreft om te starten op de arbeidsmarkt. Zo was in 2008 nog $59 \%$ van de gediplomeerden van het BBL en $48 \%$ van de gediplomeerden van het BOL tevreden met dit aspect terwijl het in $201251 \%(B B L)$, respectievelijk, 4I\% (BOL) is. Dit resultaat weerspiegelt zich ook duidelijk in het percentage dat vindt dat de opleiding (helemaal) geen goede basis bood. Binnen de MBO-BOL niveaus 3 en 4 bieden overigens de opleidingen van de sector Gezondheidszorg volgens de gediplomeerden duidelijk bovengemiddeld een (heel) goede basis. Zo is $63 \%$ van de gediplomeerden van niveau 3 en 50\% van de gediplomeerden van niveau 4 gezondheidszorgopleidingen deze mening toegedaan. Maar ook voor deze onderwijssector geldt dat 
de gediplomeerden die een opleiding in het MBO-BBL gevolgd hebben aanzienlijk meer tevreden zijn. Zo vindt niet minder dan $76 \%$ van de gediplomeerden van een opleiding in de sector Gezondheidszorg van het MBO-BBL niveau 3 of 4 dat de opleiding een (heel) goede basis bood om te starten op de arbeidsmarkt.

Van de afgestudeerden van het $\mathrm{HBO}$ is gemiddeld iets minder dan de helft van mening dat de opleiding een (heel) goede basis bood om te starten op de arbeidsmarkt. Hiertegenover staat dat zo'n een op de vijf van mening is dat de opleiding (helemaal) geen goede basis bood. De opleidingen in de sectoren Taal en Cultuur ( $26 \%$ is van mening dat de opleiding een (heel) goede basis bood) en de sector Gedrag en Maatschappij (38\%) worden daarbij duidelijk minder dan gemiddeld beoordeeld. Dit geldt ook voor opleidingen in de sector Gedrag en Maatschappij, zowel in het $\mathrm{HBO}$ als het MBO. De afgestudeerden van de sector Techniek zijn wat dit onderdeel betreft aanzienlijk positiever over de gevolgde opleiding. Van deze opleidingen vindt 6 op de Io afgestudeerden dat de opleiding een (heel) goede basis bood.

\section{Figuur 1.2}

Oordeel over opleiding als basis om te starten op de arbeidsmarkt voor werkenden in kerndomein

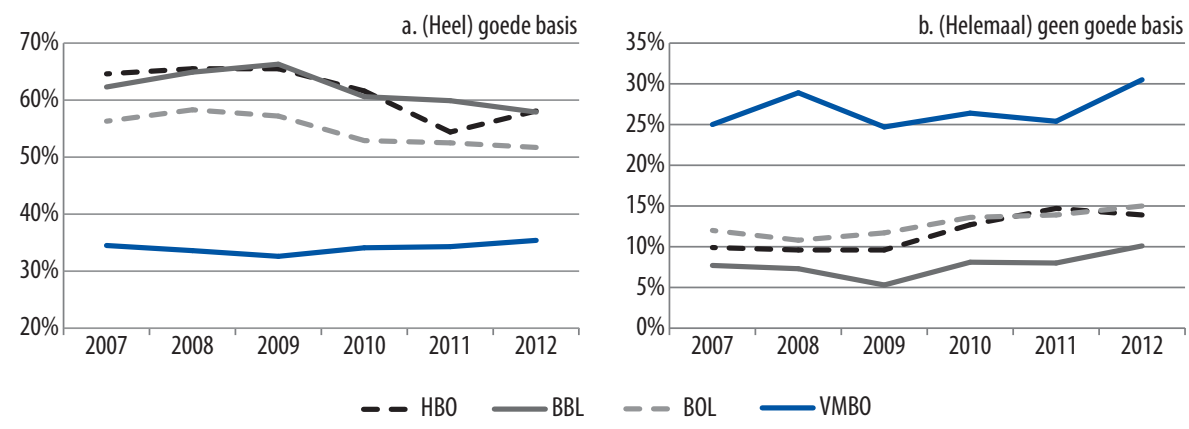

Figuur I.2a en figuur I.2b laten de ontwikkeling zien van het percentage schoolverlaters dat vindt dat de opleiding een goede basis (I.2a) dan wel geen goede basis (I.2b) om te starten op de arbeidsmarkt is geweest van meting 2007 tot en met 20I2. Om de ontwikkelingen te zuiveren van mogelijke effecten van de oplopende werkloosheid en eventuele verschuivingen naar banen onder het eigen niveau en buiten de eigen richting en de daarmee verbonden negatieve oordelen van de respondenten, worden de resultaten alleen weergeven voor respondenten die werkzaam zijn in het kerndomein van de opleiding. Hiermee bedoelen we respondenten die werkzaam zijn in een functie die zowel qua richting als niveau goed aansluit bij de gevolgde opleiding. Met uitzondering van de gediplomeerden van het VMBO zien we dat de basis om te starten op de arbeidsmarkt sinds begin van de recente economische crisis duidelijk negatiever beoordeeld wordt. Was in 2008 van de werkende respondenten met een functie in het kerndomein nog tussen de $58 \%$ (MBO-BOL gediplomeerden) en $65 \%$ (MBO-BBL gediplomeerden en $\mathrm{HBO}$ afgestudeerden) van mening dat de opleiding een (heel) goede basis bood, in 2012 is dit nog tussen de $52 \%$ en $58 \%$. Een bijna spiegelbeeld van deze uitkomst is in figuur I.2b te zien 
waar sinds 2009 het percentage dat van mening is dat de opleiding (helemaal) geen goede basis bood gestaag is toegenomen.

Naast het direct startbekwaam maken van de studenten, de korte termijn doelstelling van het onderwijs, dienen opleidingen natuurlijk ook een basis te bieden voor het verder ontwikkelen van kennis en vaardigheden in het vervolg van de (onderwijs-)carrière. Tabel I.3 laat zien hoe de respondenten op dit onderdeel oordelen. In het algemeen geldt dat de basis om kennis en vaardigheden verder te ontwikkelen aanzienlijk positiever beoordeeld wordt dan de opleiding als basis voor de start op de arbeidsmarkt. Zo vindt van alle gediplomeerden $57 \%$ dat de opleiding een (heel) goede basis bood en is slechts $\mathrm{II} \%$ van mening dat dit (helemaal) niet het geval was. De gediplomeerden van het VMBO oordelen daarbij gemiddeld. In het $\mathrm{MBO}$ zijn het wederom de gediplomeerden van het MBO-BBL niveau 4 die op dit onderdeel het meest positief oordelen. Met $70 \%$ van de gediplomeerden dat vindt dat de opleiding een (heel) goede basis bood, oordelen zij daarbij ook positiever dan de afgestudeerden van het $\mathrm{HBO}$ (63\%). Zowel in het HBO als in het MBO zijn het daarbij wederom de opleidingen in de sector Gezondheidszorg die duidelijk bovengemiddeld scoren. Van de afgestudeerden van gezondheidszorgopleidingen is namelijk tussen 60\% (MBO-BOL niveau 4) en 79\% (MBO-BBL niveau 4) van mening dat de opleiding een goede basis bood om kennis en vaardigheden verder te ontwikkelen. Onder de HBO afgestudeerden uit deze sector is dit 68\%.

Figuur 1.3

Oordeel over opleiding als basis om kennis en vaardigheden verder te ontwikkelen

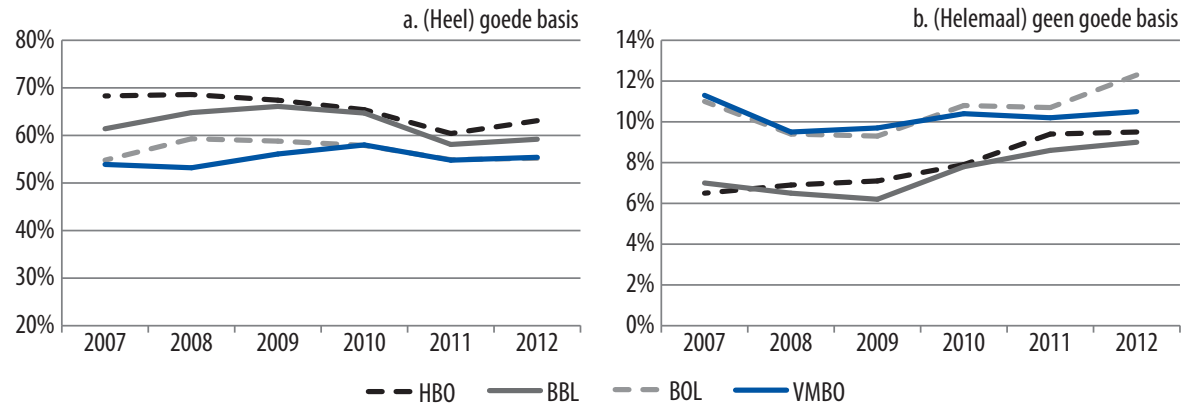

Gegeven het algemeen positieve resultaat wat de basis om kennis en vaardigheden verder te ontwikkelen betreft, is het licht verontrustend om vast te stellen dat het percentage dat het hier (helemaal) niet mee eens is op alle onderscheiden onderwijsniveaus een stijgende trend laat zien (zie figuur I.3b). Het is dan ook zeker van belang om in de toekomst nadrukkelijk te monitoren of deze trend zich voortzet of afzwakt, aangezien een verslechtering van de functie van het onderwijs als basis om kennis en vaardigheden verder te ontwikkelen negatieve gevolgen kan hebben voor de basis die het onderwijs biedt voor levenlang leren. 


\subsection{Opleiding: Selectiviteit}

De betrouwbaarheid waarmee het onderwijs haar studenten beoordeelt op de aanwezige competenties is van groot belang aangezien deze competenties voor een groot deel bepalend zijn voor het door de school gecertificeerde eindniveau. De legitimering van het diploma is dan ook voor een groot deel gelegen in de betrouwbaarheid van de competentiebeoordeling. Zowel onderwijsinstellingen zelf als ook werkgevers moeten er van uit kunnen gaan dat een schoolverlater met een bepaald eindcertificaat ook daadwerkelijk beschikt over de competenties die bij het betreffende diploma horen. Om hier een indicatie van te krijgen is aan de schoolverlaters gevraagd om over de volgende vijf aspecten hun mening te geven: I) de moeilijkheidsgraad van de opleiding, 2) de strengheid van docenten in de beoordeling van studenten, 3) de uitdagendheid van het niveau van de opleiding, 4) de pittigheid van de examens/opdrachten en 5) de mate waarin er voldoende op inzicht wordt getoetst. In deze paragraaf wordt allereerst de moeilijkheidheidsgraad van de opleiding behandeld en vervolgens de overige vier aspecten. Het gaat hierbij om subjectieve oordelen van de schoolverlaters die de opleiding succesvol hebben afgerond en het zegt dus meer over de selectiviteit tijdens de opleiding dan over de selectiviteit bij de intrede. Scholieren die de opleiding vanwege tegenvallende studieresultaten voortijdig hebben verlaten of om andere redenen niet hebben afgemaakt zullen wellicht heel anders denken over de selectie tijdens de opleiding. Niettemin geven deze indicatoren een goed beeld van de mate waarin naar het oordeel van de schoolverlaters zelf de opleiding voldoende selectief was.

\section{Moeilijkheidsgraad}

Van alle gediplomeerde schoolverlaters en afgestudeerden (zie tabel I.4) vindt I6\% dat de opleiding achteraf gezien te makkelijk was en $5 \%$ dat de opleiding te moeilijk was. Zoals eerder vermeld dient met name bij dit laatste resultaat er rekening mee te worden gehouden dat de enquête onder degenen heeft plaatsgevonden die de opleiding succesvol afgerond hebben. Onderzoek onder voortijdige schoolverlaters van het AVO laat bijvoorbeeld zien dat $28 \%$ van de ondervraagde VSV-ers aangeeft dat het niveau te hoog was en dat dit één van de belangrijkste redenen was voor het voortijdig afbreken van de studie (zie ROA-F-2013/3). Wat de moeilijkheidsgraad betreft zien we het meest opvallende resultaat bij de opleidingen van het $\mathrm{MBO}-\mathrm{BOL}$ niveau 4. Van de gediplomeerden van dit onderwijsniveau is namelijk niet minder dan $28 \%$ van mening dat de opleiding te makkelijk was. Hierbij worden de opleidingen in de sector Gezondheidszorg (23\% vond de opleiding te makkelijk) en de sector Landbouw (26\%) nog het best beoordeeld. Dat wil zeggen dat relatief weinig respondenten de opleiding achteraf te makkelijk vonden. In het $\mathrm{HBO}$ zijn het eveneens de afgestudeerden van deze twee sectoren die de opleidingen het minst vaak als 'te makkelijk' beoordelen. 
Tabel 1.4

Moeilijkheid van de gevolgde opleiding (\%)

\begin{tabular}{|c|c|c|}
\hline & Te makkelijk & Te moeilijk \\
\hline HAVO & 8 & 5 \\
\hline vW0 & 12 & 5 \\
\hline VMBO & 14 & 5 \\
\hline MBO-BOL 1 & 13 & 11 \\
\hline MBO-BOL 2 & 16 & 9 \\
\hline MBO-BOL 3 & 17 & 6 \\
\hline MBO-BOL 4 & 28 & 4 \\
\hline MBO-BBL 1 & 15 & 8 \\
\hline $\mathrm{MBO}-\mathrm{BBL} 2$ & 16 & 6 \\
\hline MBO-BBL 3 & 14 & 8 \\
\hline MBO-BBL 4 & 19 & 4 \\
\hline HBO & 15 & 3 \\
\hline Totaal & 16 & 5 \\
\hline
\end{tabular}

Zie voor de onderliggende cijfers per opleidingssector tabel 6 in de Statistische Bijlage

In het $\mathrm{HBO}$ is er wel een verschil of men op basis van een HAVO-opleiding of een VWO-opleiding is ingestroomd. Er is weliswaar weinig verschil tussen de HAVO- en de VWO-gediplomeerden als het gaat om het echt te moeilijk vinden van de opleiding (3\% versus $2 \%)$ maar aanzienlijk meer VWO-ers vinden de afgeronde $\mathrm{HBO}$-opleiding te makkelijk. Zo'n $25 \%$ van de jongeren met een VWO-diploma is die mening toegedaan terwijl dit onder de Havisten slechts $15 \%$ is.

\section{Strenge beoordeling, uitdagend niveau, pittige examens/opdrachten, toetsen op inzicht}

Naast de moeilijkheidsgraad van de opleiding is er een viertal andere aspecten van selectiviteit onderzocht. De respondenten is gevraagd in hoeverre ze het (on)eens zijn met de volgende stellingen: I) de docenten waren streng in de beoordeling van studenten, 2) de opleiding was uitdagend qua niveau, 3) de examens/opdrachten waren over het algemeen zeer pittig en 4) in de opleiding werd voldoende getoetst op inzicht. Figuur I.4 geeft per stelling het percentage weer dat het (helemaal) niet eens was met de stelling. 


\section{Figuur 1.4}

Selectiviteit van de opleiding, percentage dat het (helemaal) niet eens was met de stellingen

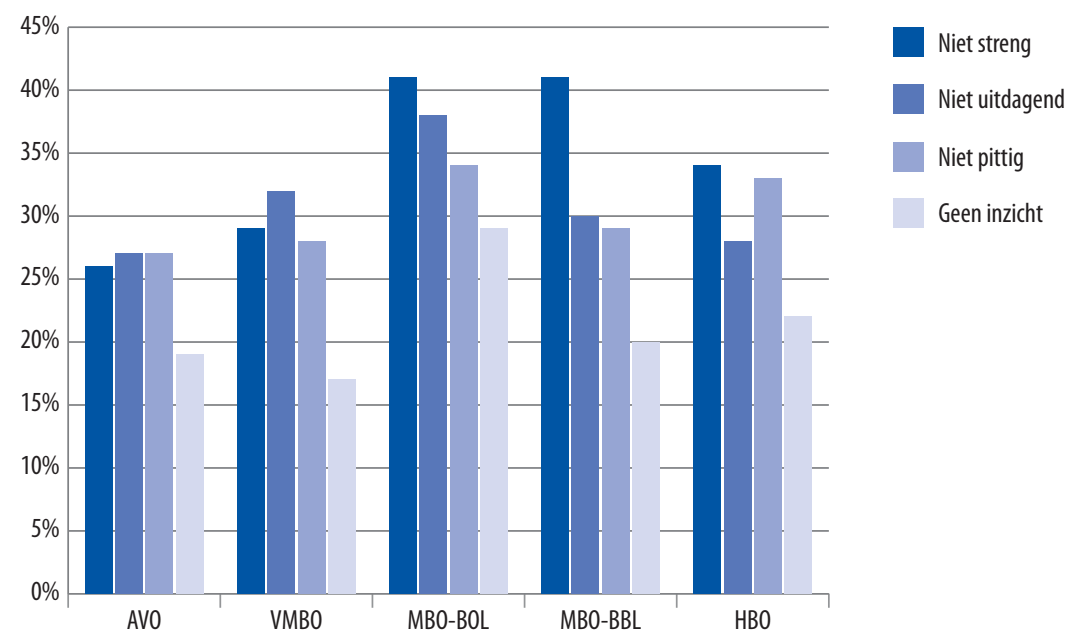

Zie voor de onderliggende cijfers per opleidingssector tabellen $7 \mathrm{t} / \mathrm{m} 10$ in de Statistische Bijlage

Op alle onderscheiden onderwijsniveaus zijn de gediplomeerden het minst vaak oneens met de stelling dat er te weinig is getoetst op inzicht. Het MBO-BOL wordt op dit onderwerp het minst goed beoordeeld (29\% is van mening dat er te weinig is getoetst op inzicht). In het $\mathrm{MBO}-\mathrm{BBL}$ is $20 \%$ het met deze stelling oneens en in het $\mathrm{HBO}$ is dit $22 \%$. Het VMBO ( $17 \%$ ) en het AVO ( $19 \%)$ worden op dit onderdeel het beste beoordeeld. Wat de andere stellingen betreft zijn de ondervraagden op alle opleidingniveaus kritischer. Zo is rond een op de vier gediplomeerden van het AVO het oneens met de stelling dat de docenten streng waren in het beoordelen, met de stelling dat de examens/opdrachten in het algemeen zeer pittig waren en met de stelling dat de opleiding uitdagend qua niveau was. Bij de gediplomeerden van het VMBO liggen de percentages van gediplomeerden dat het met deze drie stellingen oneens is rond de $30 \%$ en in het $\mathrm{MBO}$ zelfs tussen de $30 \%$ en $4 \mathrm{I} \%$. Het meest oneens zijn de gediplomeerden van het $\mathrm{MBO}$ het met de stelling dat de docenten streng waren in het beoordelen. Met uitzondering van het oordeel over de docenten worden daarbij de opleidingen in het MBO-BBL op de stellingen 'de examens/opdrachten waren over het algemeen zeer pittig' en 'de opleiding was uitdagend qua niveau' positiever beoordeeld. Hier lijkt een duidelijk verschil naar voren te komen tussen de opleidingen die (hoofdzakelijk) op school verzorgd worden en opleidingen die (hoofdzakelijk) op de werkvloer plaatsvinden. Het HBO scoort wat de selectiviteit betreft gemiddeld tussen opleidingen in het $\mathrm{MBO}$ en de opleidingen uit het voortgezet onderwijs in. Net iets minder dan $35 \%$ van de afgestudeerden van het $\mathrm{HBO}$ vindt dat de docenten niet streng waren in hun beoordelingen en dat de examens/opdrachten in het algemeen niet pittig waren. Wat de uitdaging qua niveau betreft is het $28 \%$ van de afgestudeerden van het HBO het niet eens met de stelling. 
Figuur I.5a tot en met figuur I.5e presenteren de ontwikkeling van een drietal onderdelen van selectiviteit ('docenten (helemaal) niet streng', opdrachten/examen (helemaal) niet pittig' en 'opleiding (helemaal) niet uitdagend') voor de vijf opleidingstypes. Zowel de opleidingen binnen het VMBO als het AVO laten wat deze aspecten betreft tussen meetjaar 2007 en meetjaar 2012 een duidelijke negatieve trend zien. Met andere woorden, deze opleidingen worden door steeds minder respondenten als 'niet pittig', 'niet uitdagend' en als opleidingen met 'niet strenge docenten' beoordeeld. Dit lijkt erop te wijzen dat het onderwijs steeds meer van haar studenten begint te vergen althans wat deze twee opleidingstypes betreft. Was in 2007 nog 30\% á 35\% van de AVO gediplomeerden kritisch in hun oordeel, in 2012 is dit op alle drie aspecten nog zo'n $26 \%$. In het VMBO daalden de cijfers zelfs nog sterker, namelijk van $37 \%$ á $40 \%$ naar $28 \%$ á $32 \%$. Het percentage dat de VMBO opleiding niet uitdagend vond daalde daarbij het sterkst van $40 \%$ in 2007 naar $28 \%$ in 20I2. Maar niet alleen de opleidingen in het AVO en het VMBO worden door steeds minder jongeren als niet selectief ervaren, ook de afgestudeerden van $\mathrm{HBO}$ opleidingen rapporteren een vergelijkbare, zelfs nog sterkere, trend. Was in 2007 nog $46 \%$ van de $\mathrm{HBO}$ afgestudeerden van mening dat de docenten (helemaal) niet streng waren, in $20 \mathrm{I} 2$ is dit nog maar $34 \%$. Vergelijkbaar zien we dat het percentage dat de HBO opleiding (helemaal) niet uitdagend vond (was in $200737 \%$, is in $201228 \%$ ) en het percentage dat de examens/opdrachten (helemaal) niet pittig vond (was in $20074 \mathrm{I} \%$, is in $20 \mathrm{I} 2$ $33 \%$ ) duidelijk afnam. Daarnaast, maar niet gepresenteerd in de figuur, is het HBO het enige onderwijstype waar we ook een duidelijk negatieve trend zien wat de antwoorden '(helemaal) niet op inzicht getoetst' betreft. Het percentage afgestudeerden van het HBO dat vond dat er niet op inzicht getoetst werd nam tussen 2007 en 2012 af met maar liefst 9\%-punt.

Terwijl het $\mathrm{HBO}$, het AVO en het VMBO daarmee door de gediplomeerde uitstroom steeds vaker als selectief ervaren wordt, kan dit voor het $\mathrm{MBO}$ niet gezegd worden. Zowel de gediplomeerden van het MBO-BOL als het MBO-BBL laten wat de 'niet selectiviteit' betreft in de afgelopen 5 jaren een vrij constant beeld zien. De docenten worden daarbij in beide gevallen in de hele periode gemiddeld door zo'n $45 \%$ als niet streng ervaren. Wat de twee andere aspecten betreft blijven de cijfers voor het $\mathrm{MBO}-\mathrm{BOL}$ rond de $40 \%$ en voor het $\mathrm{MBO}-\mathrm{BBL}$ rond de $30 \%$ schommelen. Het $\mathrm{MBO}$, en dan zeker het $\mathrm{MBO}-\mathrm{BOL}$, blijft wat de ontwikkeling van toenemende selectiviteit betreft dan ook achter bij de andere opleidingstypen. 


\section{Figuur 1.5}

Selectiviteit van de opleiding 2007-2012

a. AVO $50 \%$

b. VMBO

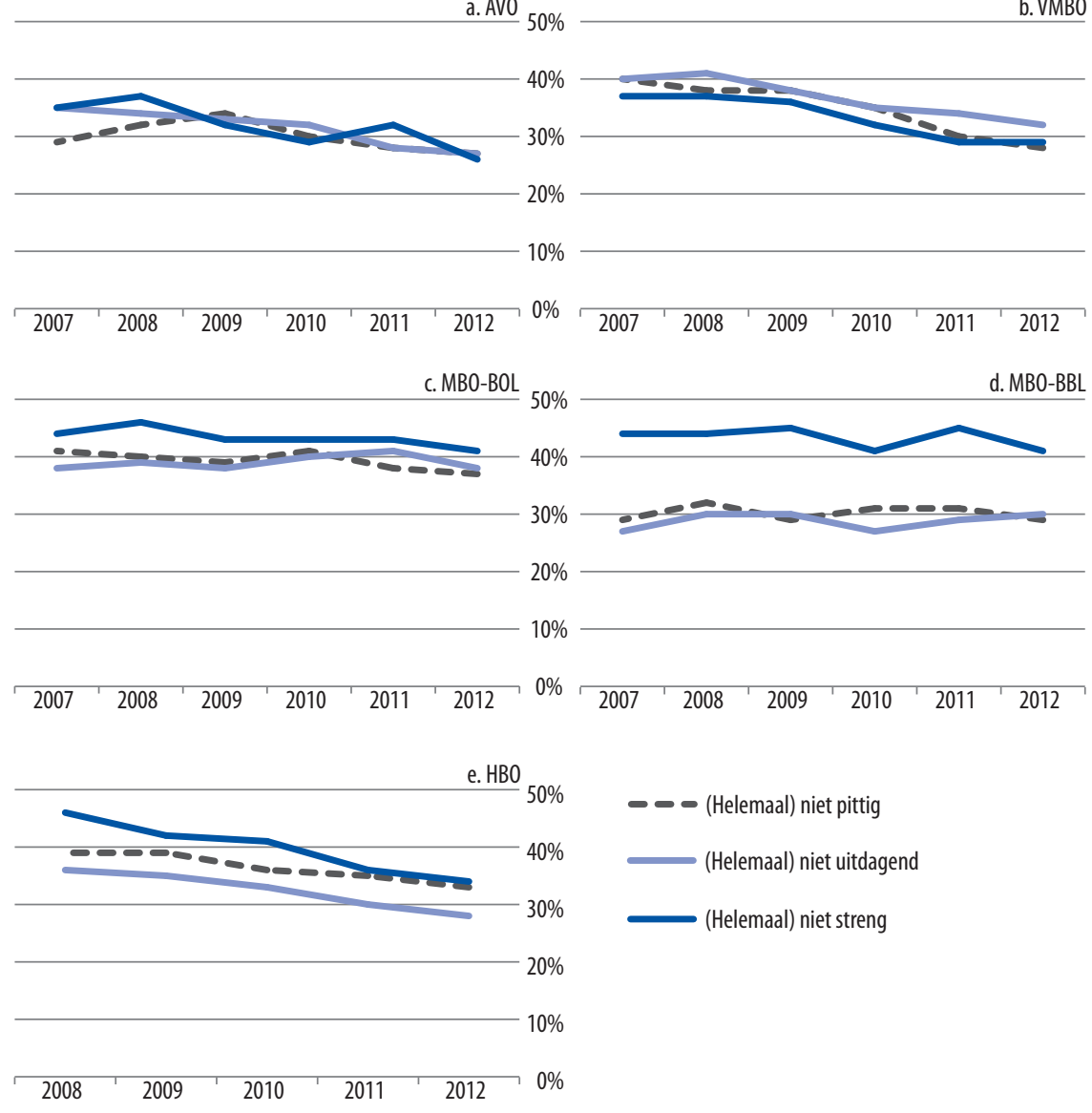

\subsection{Opleiding: Tevredenheid met opleiding}

Naast de aspecten die met de evenwichtigheid van de opleiding, de voorbereiding op de arbeidsmarkt, het verder ontwikkelen van kennis en vaardigheden en de aspecten die met de selectiviteit van de opleiding te doen hebben, is aan de respondenten ook gevraagd om over een aantal andere opleiding- dan wel schoolgerelateerde aspecten een oordeel te geven. Figuur I.6 laat de tevredenheid met deze aspecten onder de gediplomeerden van het $\mathrm{AVO}$, het VMBO en het MBO zien. Figuur I.7 doet dit voor de afgestudeerden van het $\mathrm{HBO}$. 
Figuur 1.6

Tevredenheid met opleiding VMBO, AVO en MBO

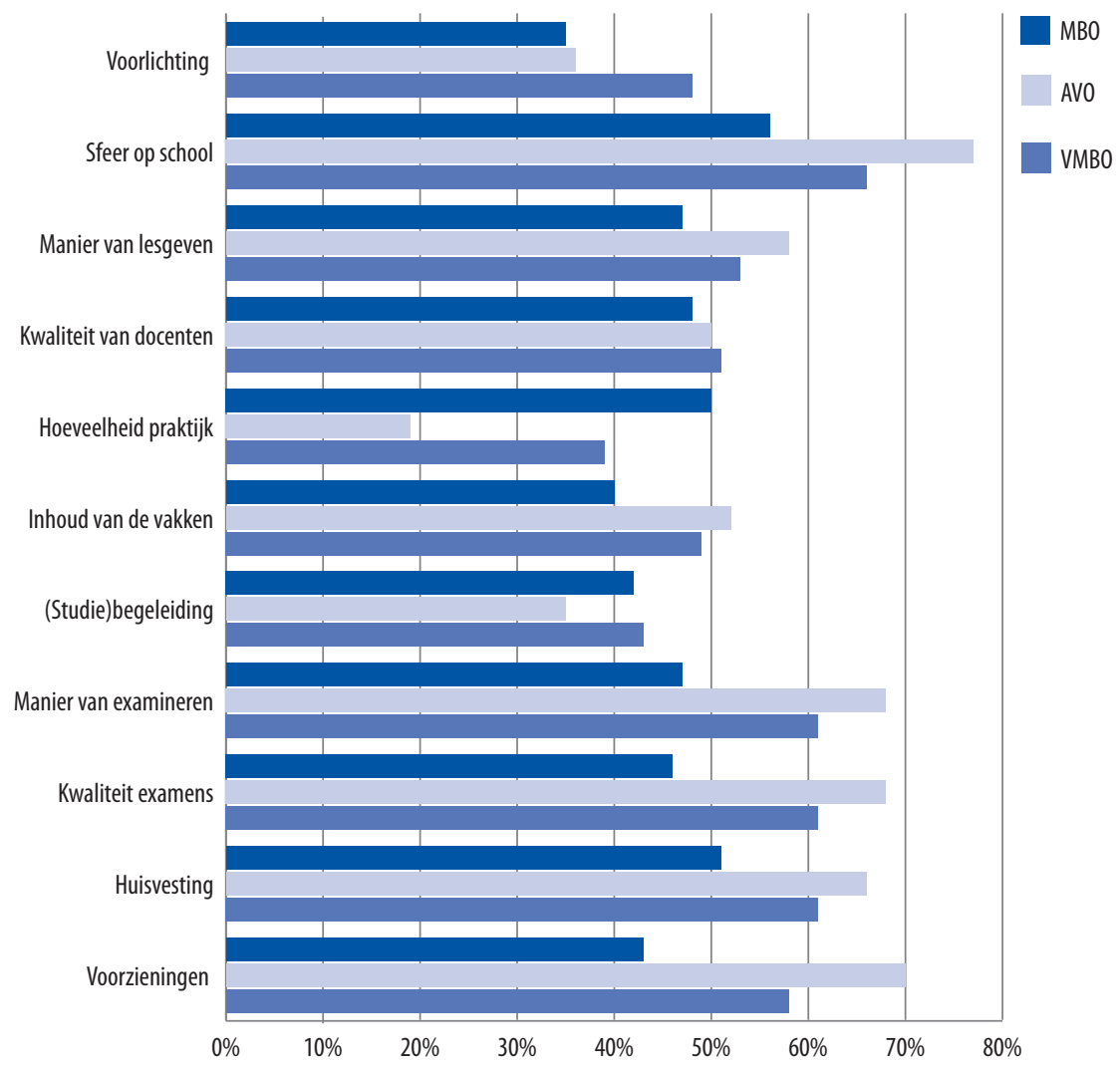

Op een vijftal aspecten zien we dat de gediplomeerden van het AVO duidelijk meer tevreden zijn dan de gediplomeerden van het $\mathrm{MBO}$ en het VMBO. Het betreft daarbij de sfeer op de school ( $77 \%$ van de AVO'ers was daarmee (zeer) tevreden), de algemene voorzieningen $(70 \%)$, de huisvestiging (66\%), de kwaliteit van de examens $(68 \%)$ en de manier van examineren (68\%). Op al deze vijf aspecten scoort het VMBO op tweede plaats met rond de $60 \%$ van de gediplomeerden die (zeer) tevreden zijn (de sfeer op de VMBO scholen wordt zelfs door $66 \%$ van gediplomeerden als zeer goed ervaren). De tevredenheid onder de gediplomeerden van het $\mathrm{MBO}$ is op deze vijf punten aanzienlijk lager. Zo is $56 \%$ van de MBO'ers (zeer) tevreden met de sfeer op de school en zijn het bij de algemene voorzieningen, de kwaliteit van de examens en de manier van examineren minder dan de helft die (zeer) tevreden is. 


\section{Figuur 1.7}

Tevredenheid met opleiding $\mathrm{HBO}$ afgestudeerden, rapportcijfers

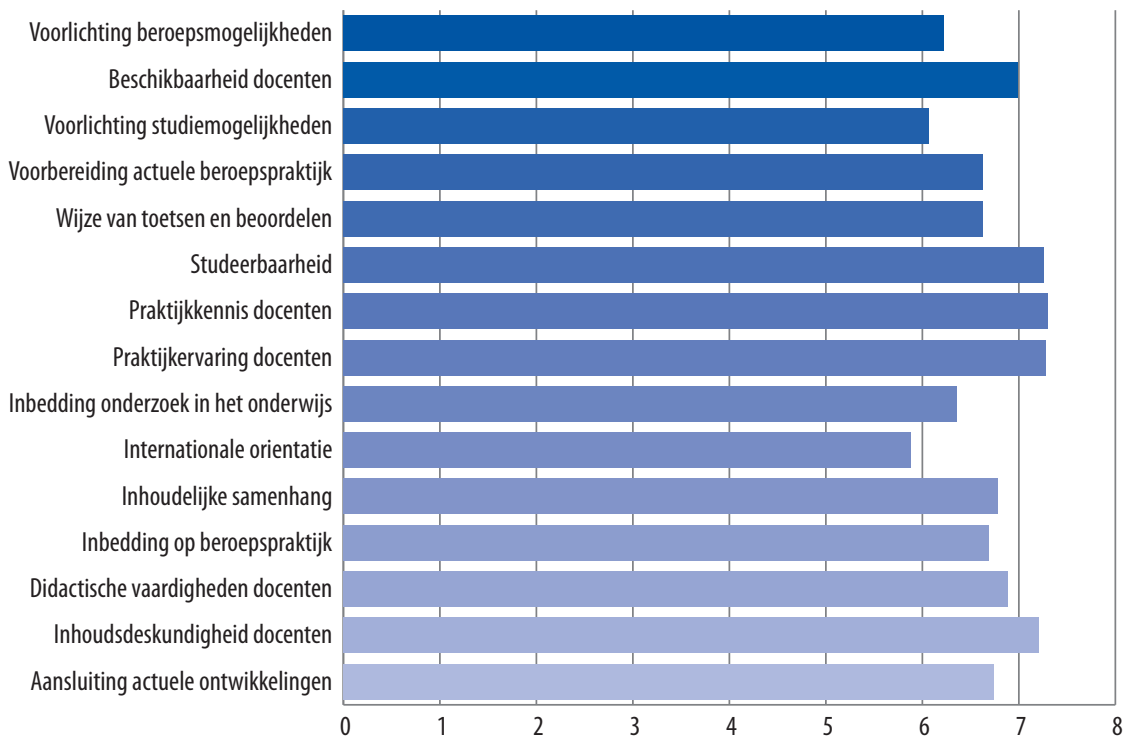

Wat de kwaliteit van de docenten en de manier van lesgeven betreft zijn onder de gediplomeerden van alle drie onderwijstypen rond de $50 \%$ tot bijna $60 \%$ (zeer) tevreden en zijn de verschillen relatief gezien kleiner. Met de inhoud van de vakken is ongeveer een op de twee gediplomeerden van het VMBO en het AVO achteraf gezien (zeer) tevreden terwijl dit bij de $\mathrm{MBO}$ 'ers met $40 \%$ wederom duidelijk lager is. Niet verrassend scoort het $\mathrm{MBO}$ relatief het beste wat de hoeveelheid praktijk betreft, maar ook hier geldt dat slechts een op de twee gediplomeerden (zeer) tevreden is. Tot slot zien we dat de gediplomeerden van alle drie onderwijstypen in minder dan de helft van de gevallen (zeer) tevreden is met de geboden (studie-)begeleiding en voorlichting. Wat het laatste punt betreft (voorlichting) scoort naast het MBO ook het AVO relatief zwak (35\% is (zeer) tevreden). Dit laatste punt komt in paragraaf I. 8 wederom aan bod als we nader stilstaan bij de geraadpleegde informatiebronnen tijdens het kiezen van een vervolgopleiding.

Aan de $\mathrm{HBO}$ afgestudeerden is gevraagd om verschillende aspcten van hun opleiding te beoordelen aan de hand van een rapportcijfer (zie figuur I.7). Alhoewel er gemiddeld genomen weinig echt hoge cijfers gegeven worden is men het meest tevreden over de docenten. Zowel als het gaat om hun inhoudsdeskundigheid, hun praktijkkennis en -ervaring en hun beschikbaarheid krijgen ze een 7 of zelfs iets meer dan een 7 als rapportcijfer. Evenals in de andere onderwijstypen scoort ook hier het onderdeel voorlichting niet echt hoog. Voor het aspect 'internationale oriëntatie' wordt nog net geen 6 gegeven maar dit hoeft op zich geen probleem te zijn. De cijfers betreffen immers gemiddelde rapportcijfers voor het gehele $\mathrm{HBO}$ en er zijn natuurlijk ook opleidingen waar het aspect internationale oriëntatie van minder of slechts gering belang is. 


\subsection{Opleidingskeuze achteraf}

Een samenvattend oordeel over de gevolgde opleiding is de vraag of men, achteraf bezien, opnieuw voor dezelfde opleiding zou kiezen (zie tabel I.5). Van alle gediplomeerde schoolverlaters en afgestudeerden zou 85\% dezelfde opleiding opnieuw kiezen. Dit percentage laat zien dat de respondenten in het algemeen uitermate tevreden zijn met de eerder gemaakte studiekeuze. Onder de gediplomeerden van het HAVO en het VWO is zelfs $96 \%$, respectievelijk $98 \%$ tevreden met de studiekeuze. Maar ook de gediplomeerden van het VMBO zouden bovengemiddeld vaak dezelfde keuze wederom maken. Wat de opleidingskeuze achteraf betreft zijn de gediplomeerden van de MBO-BOL opleidingen op niveau 2 tot en met 4 het minst tevreden, maar ook onder deze groepen zou nog steeds minimaal driekwart dezelfde keuze wederom maken. MBO-BBL gediplomeerden scoren op alle niveaus hoger dan de MBO-BOL gediplomeerden. Hierbij kan meespelen dat hun studiekeuze destijds bewuster heeft plaatsgevonden aangezien zij bij een werkgever dienden te solliciteren en wellicht al iets meer zicht hadden op de beroepsmogelijkheden van hun gekozen opleiding. HBO'ers zijn weliswaar iets minder dan gemiddeld achteraf tevreden met de gemaakte studiekeuze maar ook bij hun is bijna vier op de vijf van mening dat zij dezelfde opleiding wederom zouden kiezen.

Tabel 1.5

Tevredenheid met opleidingskeuze achteraf (\%)

\begin{tabular}{|l|c|c|}
\hline & \multicolumn{3}{|c|}{ Opleidingskeuze achteraf } \\
\hline HAV0 & Zelfde opleiding & Andere opleiding \\
\hline VW0 & 96 & 4 \\
\hline VMBO & 98 & 2 \\
\hline MBO-BOL 1 & & \\
\hline MBO-BOL 2 & 87 & 13 \\
\hline MBO-BOL 3 & & \\
\hline MBO-BOL 4 & 80 & 20 \\
\hline MBO-BBL 1 & 77 & 23 \\
\hline MBO-BBL 2 & 76 & 24 \\
\hline MBO-BBL 3 & 77 & 23 \\
\hline MBO-BBL 4 & & \\
\hline HBO & 83 & 17 \\
\hline Totaal & 85 & 15 \\
\hline
\end{tabular}

Zie voor de onderliggende cijfers per opleidingssector tabel 28 in de Statistische Bijlage

Figuur I.8 laat per onderwijssector de tevredenheid met de studiekeuze zien. Op alle onderscheiden onderwijsniveaus is zichtbaar dat gediplomeerden die een opleiding in 
de sector Techniek of de sector Gezondheidszorg hebben gevolgd relatief het meest tevreden zijn. In het $\mathrm{HBO}$ kennen daarnaast de sector Kunst, Taal en Cultuur en de sector Onderwijs een vergelijkbaar hoge tevredenheid. In het MBO-BBL geldt dit voor de gediplomeerden van de sector Landbouw. Op alle onderwijsniveaus geldt verder dat de gediplomeerden van de opleidingen in de sector Economie relatief het minst tevreden zijn met hun destijds gemaakte studiekeuze. Op HBO niveau scoren daarbij de sectoren Landbouw (geldt eveneens voor het MBO-BOL) en de sector Gedrag en Maatschappij wat de tevredenheid met de gemaakte studiekeuze betreft eveneens relatief laag. Maar ook in al deze sectoren is nog steeds een duidelijke meerderheid (meer dan 70\%) van mening dat zij dezelfde keuze wederom zouden maken. Een kanttekening bij deze cijfers is dat het hier gaat om respondenten die hun studie afgemaakt hebben, van de mensen die stoppen met de opleiding zal het overgrote deel niet weer voor dezelfde opleiding gekozen hebben.

\section{Figuur 1.8}

Tevredenheid met opleidingskeuze achteraf

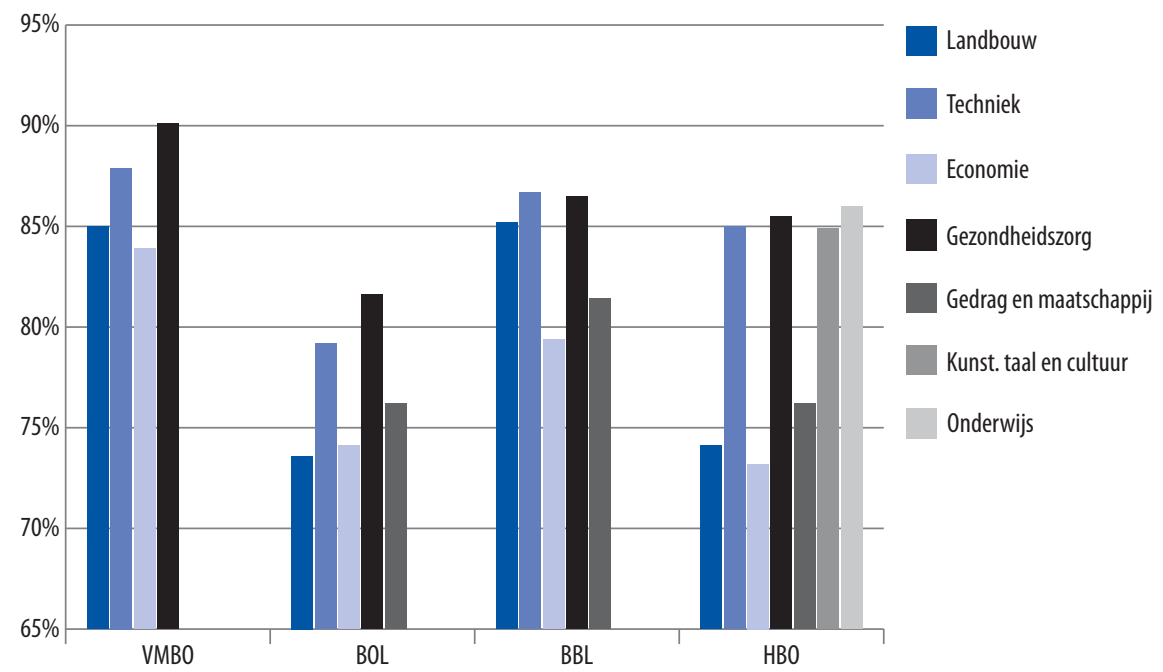

\subsection{Vervolgonderwijs: Kwalificerende vervolgtrajecten}

$\mathrm{Na}$ het behalen van het diploma kunnen jongeren er voor kiezen om een vervolg te geven aan hun onderwijsloopbaan. Deze groep komt in de paragrafen I.7 tot en met I.9 aan bod. Er wordt gekeken in hoeverre en naar welke onderwijsniveaus de gediplomeerden in het vervolgonderwijs doorstromen (paragraaf I.7). Hoe goed ze op deze stap zijn voorbereid (paragraaf I.8) en hoe succesvol ze in hun vervolgstudie zijn (paragraaf I.9). Het gaat hierbij dus om respondenten die in aansluiting op hun gevolgde opleiding gestart zijn met een nieuwe opleiding en op het enquêtemoment in de meeste gevallen dus iets meer dan een jaar met hun vervolgstudie bezig zijn. Figuur I.9 laat de belangrijkste stromen per onderwijssoort zien. 


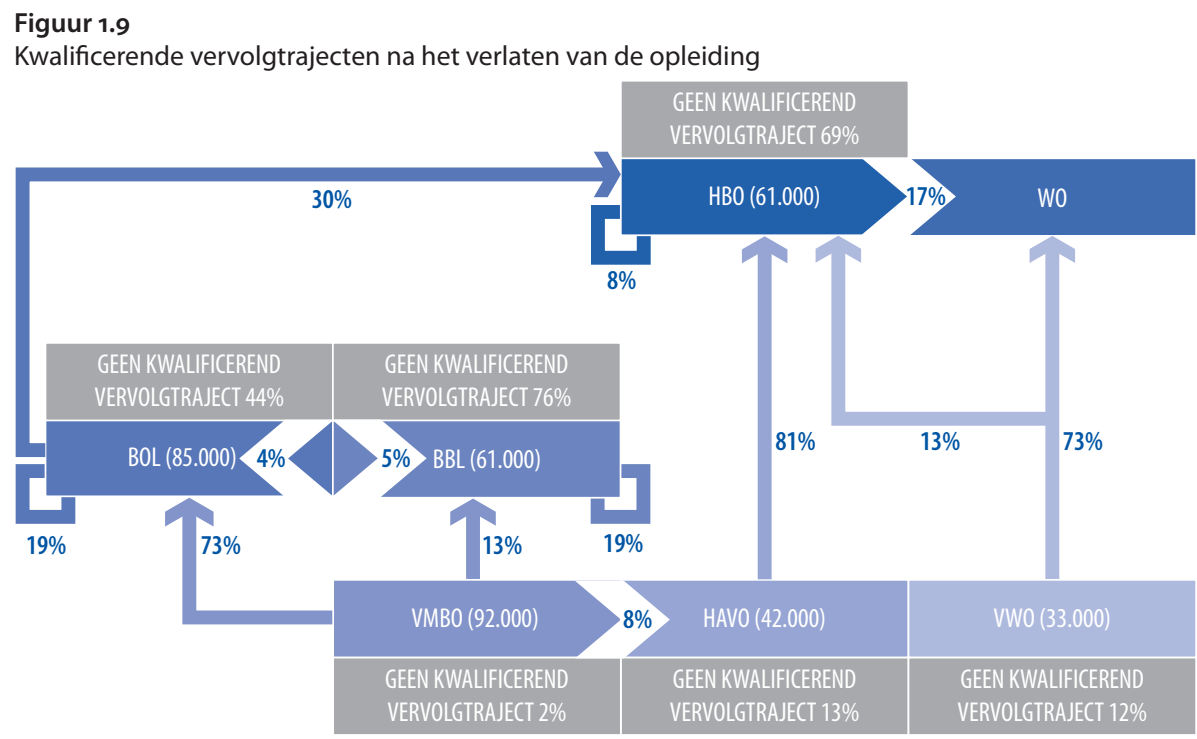

Bron: CBS Statline, SIS (ROA)

* Vanwege de duidelijkheid zijn alleen stromen met een aandeel van minstens $4 \%$ van de respondenten opgenomen.

Dat een VMBO diploma niet gezien wordt als een startkwalificatie blijkt duidelijk uit de cijfers: van de gediplomeerde VMBO'ers stroomt vrijwel iedereen door naar een vervolgopleiding. ${ }^{9}$ Het merendeel (73\%) kiest voor een MBO-BOL opleiding, een klein deel gaat naar het meer praktijkgerichte $\mathrm{MBO}-\mathrm{BBL}$ onderwijs. Ten opzichte van verleden meetjaar betekent dit een lichte daling in de doorstroom naar het MBO-BOL van 7\%-punt. Alhoewel voor het totale VMBO de doorstroom binnen het VO (naar de HAVO) maar klein is gaat van de VMBO-tl gediplomeerden toch nog zo'n I7\% verder met een HAVO opleiding. Schoolverlaters met een HAVO- of VWO-diploma op zak kiezen vrijwel allemaal voor een studie in het hoger onderwijs. Van de HAVO gediplomeerden beginnen zo'n acht van de tien met een opleiding in het HBO, bijna driekwart van de VWO gediplomeerden gaat verder met een WO-studie. Ondanks dat het VO met name bedoeld is ter voorbereiding op het vervolgonderwijs gaat nog steeds iets meer dan IO\% van de gediplomeerden niet verder met een vervolgstudie, in ieder geval niet direct in aansluiting op hun HAVO of VWO studieperiode. ${ }^{\text {IO }}$

Vanuit het $\mathrm{MBO}$ is de doorstroom naar het vervolgonderwijs aanzienlijk lager. $44 \%$ van de MBO-BOL gediplomeerden gaat niet verder met een vervolgstudie. Bijna één op de

9. Voor een uitgebreide rapportage over het $\mathrm{VMBO}$ en de doorstroom naar het vervolgonderwijs zie Doorstroomatlas VMBO: De onderwijsloopbanen van vmbo'ers in kaart gebracht. Ministerie van Onderwijs, Cultuur en Wetenschap, 2012.

Io. Het gros van de gediplomeerden van het HAVO en VWO dat niet direct voor een vervolgstudie kiest, geeft aan een tussenjaar (reizen, taalcursus) te nemen. Op moment van enquête, anderhalf jaar later, is dan ook bijna $80 \%$-punt van degenen die niet direct met een vervolgopleiding waren gestart teruggekeerd in het onderwijs. 
drie MBO-BOL gediplomeerden kiest voor een $\mathrm{HBO}$ vervolgstudie. Deze groep bestaat voornamelijk uit niveau 4 gediplomeerden. De doorstroom binnen de eigen BOL leerweg is $19 \%$. Vanuit de MBO-BBL gaan de meeste gediplomeerden niet verder in het onderwijs. Van degenen die wel verder leren kiezen de meesten wederom voor een opleiding in de BBL, slechts een kleine groep stapt over naar de BOL. Het $\mathrm{HBO}$ is voor veel van de gediplomeerden het eindstation als het om hun studietraject gaat. Bijna $70 \%$ gaat niet verder in het onderwijs en kiest voor het merendeel voor de arbeidsmarkt.

\section{Figuur 1.10}

Kwalificerende MBO-vervolgtrajecten na het verlaten van de VMBO-opleiding

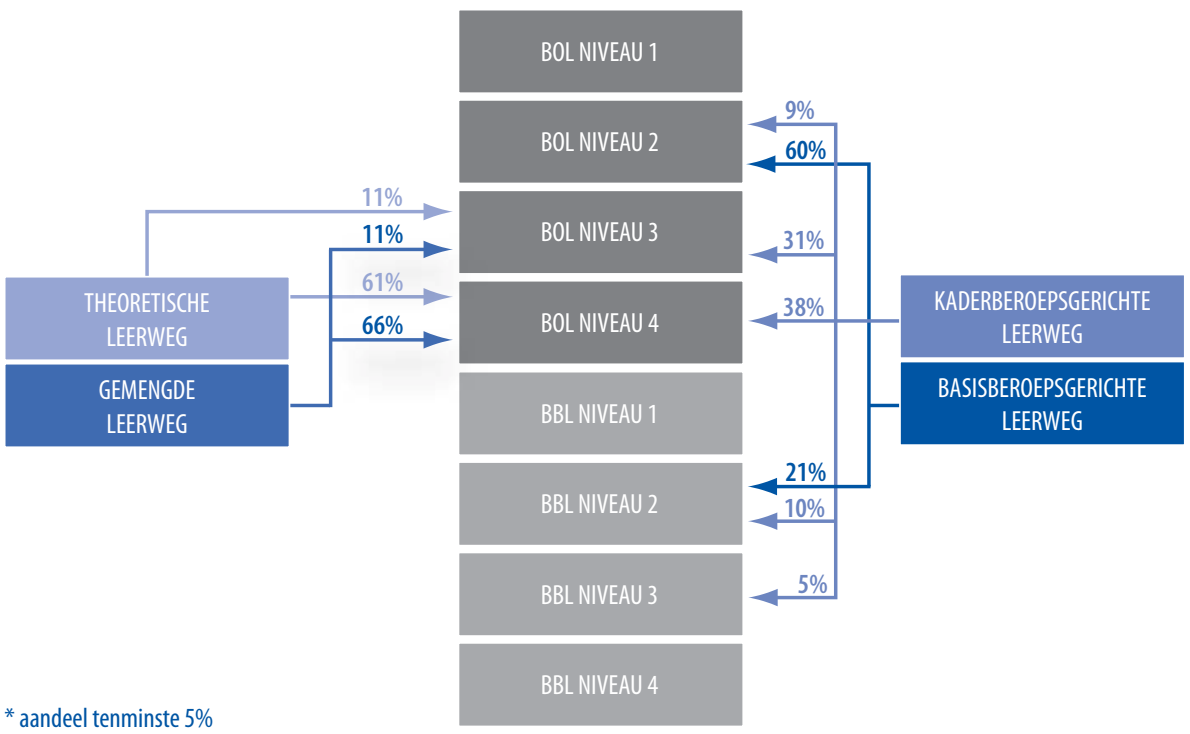

Omdat het VMBO diploma geen startkwalificatie is blijft de doorstroom van het VMBO, en dan met name de doorstroom naar het $\mathrm{MBO}$ wat voor $\mathrm{VMBO}$-gediplomeerden een logisch vervolg is, een belangrijke leerlingstroom in het Nederlandse onderwijsstelsel. Figuur I.Io brengt daarom de doorstroom van de verschillende VMBO leerwegen naar het $\mathrm{MBO}$ in kaart. Vanwege de duidelijkheid zijn hierbij aandelen van minder dan $5 \%$ niet in de figuur opgenomen.

De gediplomeerden van de VMBO basisberoepsgerichte leerweg stromen met name door naar $\mathrm{MBO}$ niveau 2 opleidingen. Het overgrote deel, 60\%, kiest hierbij voor een $\mathrm{MBO}-\mathrm{BOL}$ opleiding hetgeen een lichte stijging is ten opzichte van het vorige meetjaar. Ook van de gediplomeerden van de kaderberoepsgerichte leerweg stroomt het merendeel naar de BOL maar dan naar de niveau 3 en 4 opleidingen, samen bijna $70 \%$. Ten opzichte van verleden meetjaar is er wel sprake van een lichte verschuiving van de doorstroom van de niveau 4 naar de niveau 3 opleidingen vanuit de kaderberoepsgerichte leerweg. Zo'n I5\% stroomt naar de niveau 2 en 3 opleidingen van het MBO-BBL. Vanuit de gemengde 
en de theoretische leerweg stroomt het merendeel, dat wil zeggen meer dan 60\%, door naar het MBO-BOL niveau 4 onderwijs. Zo'n IO\% kiest voor de MBO-BOL maar dan voor een opleiding op niveau 3 .

\subsection{Vervolgonderwijs: Voorbereiding en aansluiting}

Een succesvol vervolg in de onderwijsloopbaan vereist een goede voorbereiding op de mogelijke vervolgopleidingen. In deze paragraaf staan we voor de gediplomeerden van het AVO en het VMBO nader stil bij deze voorbereiding. Voordat we echter op deze voorbereiding ingaan, laat figuur I.II zien hoe tevreden de gediplomeerden in het algemeen zijn met de aansluiting tussen de gevolgde opleiding en de vervolgopleiding. MBO niveau 4 gediplomeerden die doorstromen naar een vervolgopleiding, vaak in het $\mathrm{HBO}$, melden relatief gezien de minst goede aansluiting met de vervolgopleiding. Zo vindt $23 \%$ van de MBO-BOL niveau 4 gediplomeerden de aansluiting goed en $37 \%$ ten minste nog redelijk. Onder de gediplomeerden van het MBO-BBL niveau 4 die hun onderwijscarrière voortzetten zijn de cijfers $30 \%$, respectievelijk, 33\%. Wat een 'goede' aansluiting betreft melden slechts de gediplomeerden van het HAVO een vergelijkbaar laag cijfer (30\%). Echter, van de groep HAVO'ers die doorstromen meldt wel een relatief grote groep (42\%) een 'redelijke' aansluiting. Afgaand op deze cijfers lijkt het erop dat vooral de aansluiting met het $\mathrm{HBO}$, het 'reguliere' vervolgonderwijs voor de gediplomeerden van $\mathrm{MBO}$ niveau 4 en het HAVO nogal moeilijk verloopt. Van alle andere onderscheiden onderwijsniveaus vermeldt minimaal 35\% (VMBO) een 'goede' aansluiting en komt het percentage goede/ redelijke aansluiting uit op minimaal 60\% (MBO-BOL niveau 4).

Om een goede aansluiting met de vervolgopleiding te bevorderen is het belangrijk dat jongeren goed voorbereid worden op hun vervolgtraject. Een belangrijk aspect hierbij is de beschikbaarheid van voldoende informatiebronnen zodat de studiekeuze op relevante en toegankelijke informatie gebaseerd kan worden. Navolgend staan we voor de gediplomeerden van het VMBO en het AVO dan ook nader stil bij hun oordeel over de voorbereiding op het vervolgonderwijs en dan met name bij de geraadpleegde informatiebronnen bij de studiekeuze.

Tabel I.6 laat per profiel binnen het AVO zien hoe tevreden de gediplomeerden zijn met betrekking tot de voorbereiding op het vervolgonderwijs en hoe zij over de aansluiting oordelen. Van alle afgestudeerden beoordeelt $79 \%$ de voorbereiding als voldoende of goed en vindt een vergelijkbaar percentage de aansluiting goed dan wel redelijk. Dat voorbereiding niet een op een loopt met een goede aansluiting wordt zichtbaar als we de resultaten nader per onderscheiden profiel bekijken. Terwijl het percentage dat de voorbereiding als voldoende dan wel zelfs goed beoordeelt onder de gediplomeerden van het profiel 'Cultuur en Maatschappij' met 79\% zo'n IO\%-punt lager ligt dan bij de gediplomeerden van de sector 'Natuur en Techniek' oordeelt de eerste groep jongeren toch aanzienlijk vaker positief over de aansluiting dan de tweede groep jongeren ( $82 \%$ versus $74 \%$ ). Gemiddeld het meest positief over de twee aspecten oordelen de gediplomeerden 
van een Combinatieprofiel. Van hen vindt zowel $85 \%$ dat de voorbereiding voldoende dan wel goed als ook dat de aansluiting redelijk of goed was.

\section{Figuur 1.11}

Aansluiting met vervolgonderwijs

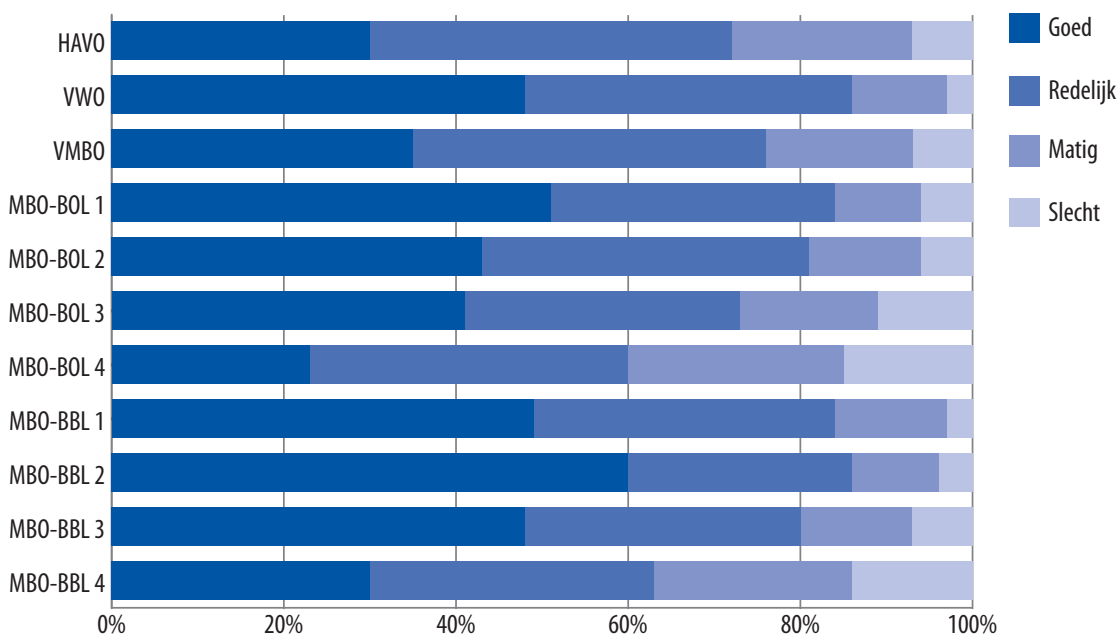

Zie voor de onderliggende cijfers per opleidingssector tabel 12 in de Statistische Bijlage

\section{Tabel 1.6}

Oordeel van AVO gediplomeerden over voorbereiding en aansluiting op vervolgonderwijs naar AVO-profiel (\%)

\begin{tabular}{|l|r|r|}
\hline & $\begin{array}{r}\text { Voldoende /goede voorbereiding } \\
\text { op vervolgonderwijs }\end{array}$ & $\begin{array}{r}\text { Voldoende/goede aansluiting } \\
\text { met vervolgopleiding }\end{array}$ \\
\hline Cultuur en maatschappij & 79 & 82 \\
\hline Economie en maatschappij & 75 & 75 \\
\hline Natuur en gezondheid & 72 & 75 \\
\hline Natuur en techniek & 89 & 74 \\
\hline Combinatieprofiel & 85 & 85 \\
\hline Totaal & 79 & 78 \\
\hline
\end{tabular}

Tabel I.7 presenteert dezelfde cijfers als tabel I.6 maar dan naar de leerwegen binnen het VMBO. Wat direct opvalt is dat zij wat de voorbereiding betreft aanzienlijk kritischer zijn dan hun studiecollega's afkomstig van het AVO. Zo vindt 'slechts' tussen de $48 \%$ tot $57 \%$ van hen dat de voorbereiding voldoende dan wel goed was. Opvallend is dat dit zich niet direct negatief lijkt uit te werken op de aansluiting. Immers, met gemiddeld $77 \%$ (variërend van $74 \%$ in de theoretische leerweg tot $80 \%$ in het geval van de gemengde leerweg) oordelen de gediplomeerde VMBO'ers vergelijkbaar met de gediplomeerde AVO'ers over de aansluiting met hun vervolgstudie. 
Zoals uit paragraaf $\mathrm{I} .7$ is gebleken stroomt van de VMBO-tl gediplomeerden een klein deel ( $17 \%)$ door naar de HAVO. Deze groep vindt in iets mindere mate (67\% versus $77 \%)$ dan de VMBO-tl gediplomeerden die doorstromen naar de MBO-BOL dat de aansluiting met de vervolgopleiding goed tot redelijk is. Met $52 \%$ zijn ze wel net iets vaker dan de doorstroom naar de MBO-BOL tevreden tot zeer tevreden over de voorbereiding op hun vervolgopleiding maar de verschillen zijn gering. De tevredenheid over de aansluiting en de voorbereiding van de VMBO-tl doorstroom naar de $\mathrm{MBO}-\mathrm{BBL}$ opleidingen ligt duidelijk lager. Dit laaste geldt eigenlijk voor het gehele VMBO. Het lijkt er op dat men zowel wat aansluiting met als wat voorbereiding op het vervolgonderwijs tevredener is over de doorstroom naar de BOL- dan de BBL-opleidingen binnen het $\mathrm{MBO}$.

\section{Tabel 1.7}

Oordeel van VMBO gediplomeerden over voorbereiding en aansluiting op vervolgonderwijs naar VMBO leerweg

\begin{tabular}{|l|r|r|} 
& (Zeer) tevreden met voorbereiding op & Voldoende/goede aansluiting met \\
vervolgonderwijs (\%) & 48 & 74 \\
\hline Theoretischelgopleiding (\%)
\end{tabular}

Een belangrijk onderdeel in het voorbereiden op het vervolgonderwijs spelen de beschikbare informatiebronnen bij het maken van de studiekeuze tijdens de overgang van gevolgde opleiding naar vervolgopleiding. Aan de gediplomeerden van het VMBO, het HAVO en het VWO is daarom in de vragenlijst gevraagd om aan te geven a) welke informatiebronnen zij voor het maken van deze keuze geraadpleegd hebben en b) wat volgens hun de belangrijkste informatiebron was. Figuur I.I2 laat per opleidingsniveau het gebruik van informatiebronnen zien. Respondenten hadden de mogelijkheid om meerdere bronnen te noemen, de percentages staan dus voor dat deel van de respondenten die de informatiebron genoemd heeft. Tabel I.8 geeft een overzicht van de belangrijkste informatiebronnen.

HAVO en VWO gediplomeerden hebben het meest gebruik gemaakt van voorlichtingsdagen van de vervolgopleiding en van informatie afkomstig van websites van vervolgopleidingen. Zo is meer dan $80 \%$ van de VWO-ers op een voorlichtingsdag geweest, dit geldt ook voor $74 \%$ van de HAVO'ers. Informatiebronnen waar eveneens meer dan $50 \%$ van de VWO'ers gebruik van hebben gemaakt zijn algemene folders en brochures, meeloopdagen georganiseerd door de vervolgopleiding, algemene studiekeuze websites en informatie afkomstig van docenten en decanen van de eigen opleiding. Met uitzondering van de algemene folders en brochures werden deze bronnen ook door meer dan 50\% van de Havisten geraadpleegd.

De gediplomeerden van het VMBO melden wat de informatiebronnen betreft een wat ander gebruik. Met net iets meer dan 50\% gebruik scoren 'voorlichtingsdagen vervolg- 
opleiding' en 'docenten/decanen van gevolgde opleiding' het hoogst. Daarnaast volgt informatie afkomstig van websites van vervolgopleidingen en voorlichtingsdagen georganiseerd door de eigen opleiding.

\section{Figuur 1.12}

Gebruikte informatiebronnen bij studiekeuze (\% genoemd, meerdere antwoorden mogelijk)

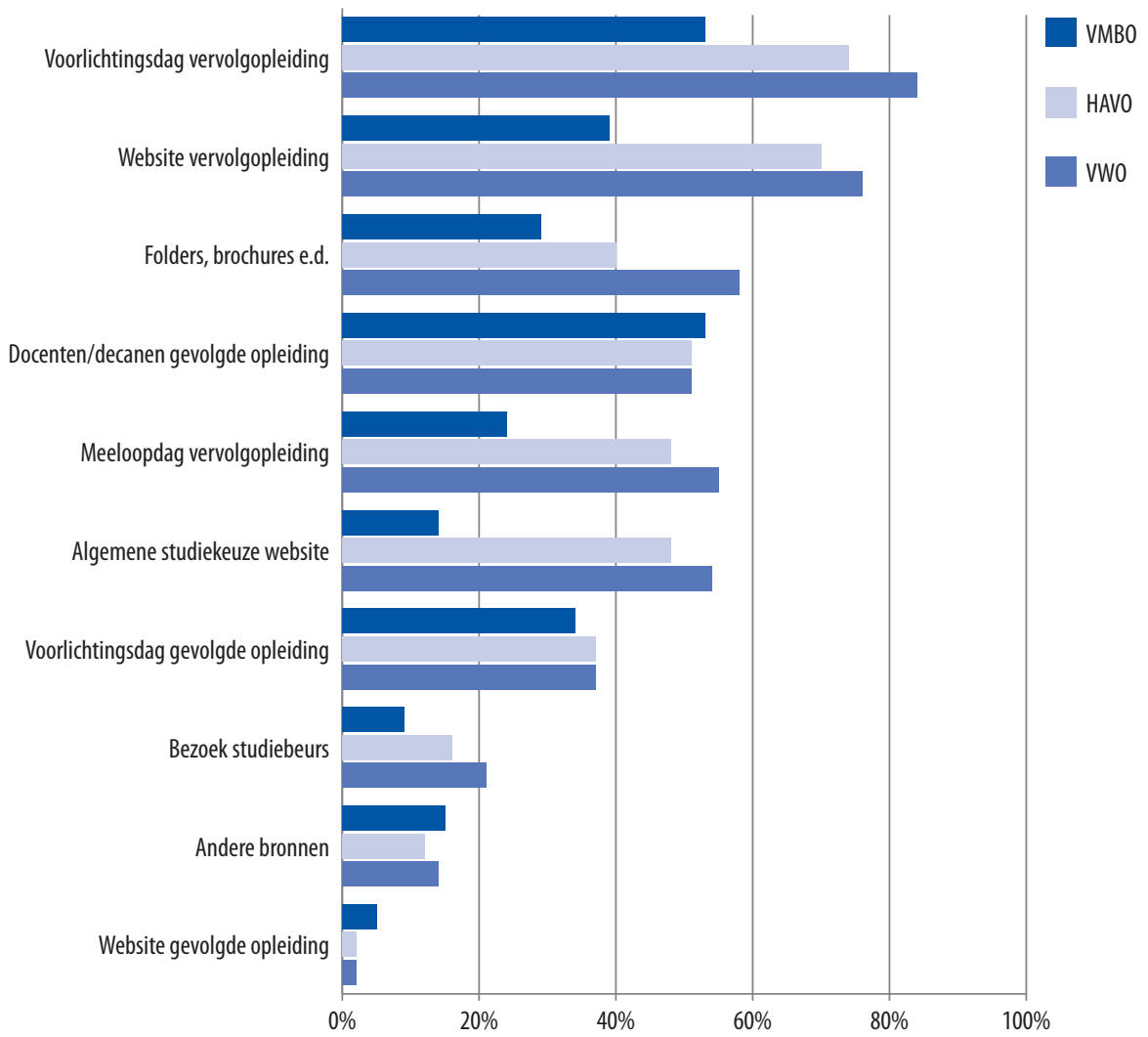

Kijken we niet naar het algemene gebruik, maar naar de vraag welke informatiebron door de respondenten als belangrijkste bij de studieuze wordt gezien (zie tabel I.8) dan komen eveneens relatief grote verschillen tussen de gediplomeerden van het VMBO aan de ene kant en de gediplomeerden van het AVO aan de andere kant naar voren. Voor beide groepen zijn de voorlichtingsdagen gegeven door de vervolgopleiding de meest genoemde belangrijkste bron. Onder de Havisten en VWO-ers volgt op een tweede plaats echter de 'meeloopdagen vervolgopleiding' terwijl dit bij de VMBO'ers met $27 \%$ de 'overige informatiebronnen' zijn. Belangrijke kanttekkening is daarbij dat onder deze categorie ook ouders, familie of vrienden vallen die blijkbaar een belangrijkere bron van informatie zijn onder de VMBO'ers dan onder de AVO'ers. Daarnaast is voor bijna I op de 5 VMBO'ers de belangrijkste bron van informatie de docenten/decanen van het VMBO. Deze groep speelt bij de gediplomeerden van het HAVO en het VWO daarentegen weer een opvallend kleine rol. 
Tabel 1.8

Belangrijkste informatiebron bij studiekeuze (\%)

\begin{tabular}{|l|r|r|r|}
\hline & VMBO & HAVO & VWO \\
\hline Docenten/decanen gevolgde opleiding & 18 & 5 & 4 \\
\hline Voorlichtingsdagen vervolgopleiding & 33 & 37 & 34 \\
\hline Meeloopdagen vervolgopleiding & 13 & 28 & 15 \\
\hline Websites vervolgopleiding & 9 & 13 & 16 \\
\hline Overige informatiebronnen & 27 & 17 & 31
\end{tabular}

In de volgende paragraaf komen we nog een keer terug op de belangrijkste informatiebronnen bij de studiekeuze en analyseren we kort de relatie met het succes in het vervolgonderwijs.

\subsection{Vervolgonderwijs: Succes}

Een van de belangrijkste functies van het onderwijs is het voorbereiden van leerlingen op een eventueel vervolgtraject in het onderwijs. Een goede voorbereiding zal er toe leiden dat leerlingen niet alleen de goede studiekeuze maken maar ook tot een lagere uitval in het vervolgonderwijs. Om inzicht in dit studiesucces te krijgen kijken we naar het percentage dat op moment van enquêtering (ongeveer anderhalf jaar na het behalen van het diploma) de vervolgopleiding alweer heeft verlaten. Omdat het verlaten van een vervolgopleiding niet gelijk hoeft te staan aan het verlaten van het onderwijs maken we daarbij een onderscheid tussen het wisselen van vervolgopleiding en het echt verlaten van het onderwijs. In figuur I.I3 staat het aandeel gediplomeerden dat de vervolgopleiding voortijdig heeft verlaten zonder direct aan een andere opleiding begonnen te zijn (de netto uitval) alsmede het aandeel dat van studie gewisseld is.

In totaal geeft $13 \%$ van de verder lerende schoolverlaters op het enquêtemoment aan gestopt te zijn met de aanvankelijk gekozen vervolgopleiding. Van alle onderwijsniveaus zijn het de Havisten die het vaakst voortijdig stoppen met de vervolgopleiding (26\%). Een meer dan gemiddelde uitval in de vervolgopleiding zien we ook bij de gediplomeerden van het $\mathrm{MBO}-\mathrm{BOL}$ niveau 4 ( $17 \%)$. Doorstromers van de $\mathrm{MBO}$ niveau I opleidingen en het VWO kennen een gemiddelde uitval. Doorstromers van het $\mathrm{HBO}$ en de andere $\mathrm{MBO}$ niveaus doen het beter dan gemiddeld.

Het percentage 'afhakers' vlak na aanvang van de vervolgstudie is in werkelijkheid echter minder problematisch dan het op het eerste gezicht lijkt. Wellicht nog belangrijker dan de totale groep 'afhakers', is het percentage van hen dat ook niet meer aan een andere studie begint. Met andere woorden de netto uitval is wat relevanter dan de bruto uitval. Dit neemt niet weg dat studiewisselaars vaak aanzienlijke studievertraging oplopen en niet alleen persoonlijk extra kosten hebben maar ook op macro niveau voor hogere onderwijskosten zorgen. Toch rijst de vraag: welk deel van de uitvallers zijn studiewisselaars en welk deel heeft daadwerkelijk het onderwijs verlaten? 
Figuur 1.13

Netto uitval en studiewisselaars

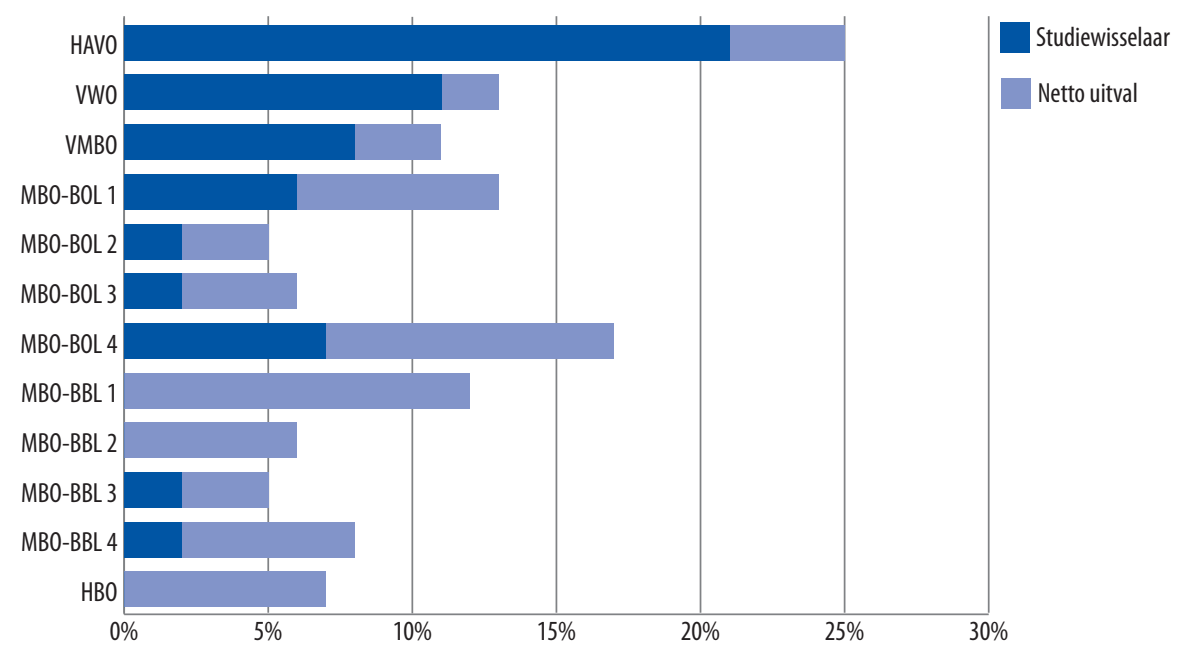

Zie voor de onderliggende cijfers per opleidingssector tabel 13 in de Statistische Bijlage

Van de $\mathbf{3} 3 \%$ doorstromers die voortijdig gestopt zijn met de vervolgopleiding is $9 \%$-punt van studie gewisseld. Deze jongeren blijven dus voor het onderwijs behouden maar lijken in eerste instantie een verkeerde studiekeuze te hebben gemaakt. De overige 4\%-punt bestaat uit netto uitvallers. Vergelijkbare cijfers zien we ook voor de doorstromers van het VMBO ( $8 \%$ studiewisselaars en 3\% netto uitval). Het relatief grote percentage uitvallers onder Havisten bestaat voor het grootse deel uit studiewisselaars (2I\%) en dat geldt nog in sterkere mate voor de gestopte VWO'ers (II\%-punt is van studie gewisseld en slechts $2 \%$-punt definitief gestopt). Hiertegenover staat dat de, weliswaar relatief kleine, groep gediplomeerden van het $\mathrm{MBO}-\mathrm{BBL}$ dat de vervolgopleiding vroegtijdig verlaat het onderwijs dan ook vaak definitief verlaat.

Het lijkt er op dat het enkel bezoeken van algemene informatiewebsites het minst efficiënt is als het gaat om informatiebronnen bij de studiekeuze. Zo hebben uitvallers en studiewisselaars iets minder vaak gebruikt gemaakt van bijvoorbeeld docenten en decanen bij hun studiekeuze en wat vaker van de websites van de vervolgopleidingen. Ook als we naar de groep verder lerende schoolverlaters kijken die de website van de vervolgopleiding, een algemene studiekeuzewebsite of folders en brochures e.d. als hun belangrijkste informatiebron noemen, dan zien we dat in deze groep het aandeel studiewisselaars twee keer zo groot is (20\% versus zo'n IO\%) als onder de groepen die andere informatiebronnen als belangrijkste genoemd hebben. Omdat deze groep echter voor de meest toegankelijke, makkelijke informatiebronnen gekozen heeft kan het zijn dat deze studiekiezers bij voorbaat al wat minder gemotiveerd waren en daardoor vaker van studie gewisseld zijn.

Aan de gediplomeerden van het VMBO, het $\mathrm{MBO}$ en het AVO die op moment van enquêtering alweer met hun vervolgopleiding zijn gestopt is gevraagd wat de reden hier- 
voor was. Tabel I.9 geeft een overzicht van de genoemde redenen en onderscheidt daarbij wederom de groep studiewisselaars van de groep die het onderwijs (ten minste tijdelijk) heeft verlaten (netto uitvallers). Niet verrassend speelt bij 50\% van de studiewisselaars de 'keuze voor een andere opleiding' een belangrijke reden terwijl dit bij de netto uitvallers bij slechts $15 \%$ het geval is. 'Onvoldoende motivatie' is bij de groep netto uitvallers (4I\%) de meest genoemde reden en speelt ook bij de groep studiewisselaars (44\%) een grote rol. Naast deze twee redenen is het vooral een drietal direct aan de opleiding gerelateerde redenen die bij minimaal een op de vijf een belangrijke rol spelen, namelijk 'lessen niet interessant genoeg'( $27 \%$, respectievelijk $35 \%)$, 'organisatie was slecht' (23\%, respectievelijk, I9\%) en 'opleiding te moeilijk, te specialistisch (22\%, respectievelijk $28 \%$ ).

\section{Tabel 1.9}

Redenen voor voortijdig verlaten van vervolgopleiding (\% genoemd, meerdere antwoorden mogelijk)

\begin{tabular}{|l|r|r|}
\hline & Netto uitvallers & Studiewisselaars \\
\hline Keuze voor andere opleiding & 15 & 49 \\
\hline Onvoldoende gemotiveerd & 41 & 44 \\
\hline Lessen niet interessant genoeg & 27 & 35 \\
\hline Organisatie was slecht & 23 & 19 \\
\hline Opleiding te moeilijk, te specialistisch & 22 & 28 \\
\hline Vanwege persoonlijke problemen & 16 & 10 \\
\hline Passend werk aangeboden gekregen & 5 & 1 \\
\hline Reisafstand bezwaarlijk & 4 & 5 \\
\hline Combinatie met thuissituatie te zwaar & 3 & 1 \\
\hline Sfeer op school & 7 & 14 \\
\hline Gepest op school & 2 & 1 \\
\hline Niet veilig op school & 2 & 1 \\
\hline
\end{tabular}

Onder de netto uitvallers zijn degenen die stoppen met de vervolgopleiding en alleen in het bezit zijn van een VMBO of MBO niveau I diploma het meest kwetsbaar. Toch geeft onder deze groep ${ }^{\text {II }}$, die dus niet in het bezit is van een startkwalificatie, nog iets meer dan IO\% van de respondenten als een van de redenen voor het stoppen met de vervolgopleiding aan dat ze passend werk aangeboden hebben gekregen. Ook geeft ongeveer een kwart aan dat ze liever een andere opleiding hadden willen doen terwijl onder de gehele groep uitvallers dit $15 \%$ is. Ze vinden de opleiding minder vaak te moeilijk of te specialistisch dan de groep netto uitvallers als geheel (IO\% versus $22 \%$ in tabel I.9).

II. Behalve dat het in deze groep gaat om respondenten met maximaal een VMBO- of MBO niveau I diploma is er ook geselecteerd op personen die 23 jaar of jonger zijn. 


\section{Box B.2}

Voortijdige Schoolverlaters

In het najaar van 2012 heeft in het kader van het project SchoolverlatersInformatieSsyteem eveneens een enquête plaatsgevonden onder de groep ongediplomeerde voortijdige schoolverlaters. Dit zijn leerlingen die in het schooljaar 2010-2011 zonder diploma hun opleiding in het voortgezet onderwijs (VMBO, HAVO, VWO) of in het MBO hebben verlaten zonder in het bezit te zijn van een startkwalificatie. Voor een uitgebreidere bespreking van de resultaten zie Voortijdige Schoolverlaters 2012 (ROA-F-2013/3)

Aan deze groep vsv'ers is gevraagd wat voor hen de belangrijkste reden voor hun voortijdige uitval is geweest. In figuur B.1 zijn deze belangrijkste redenen weergegeven per opleidingsniveau.

\section{Figuur B.2}

Belangrijkste reden voor voortijdige uitval, per opleidingsniveau

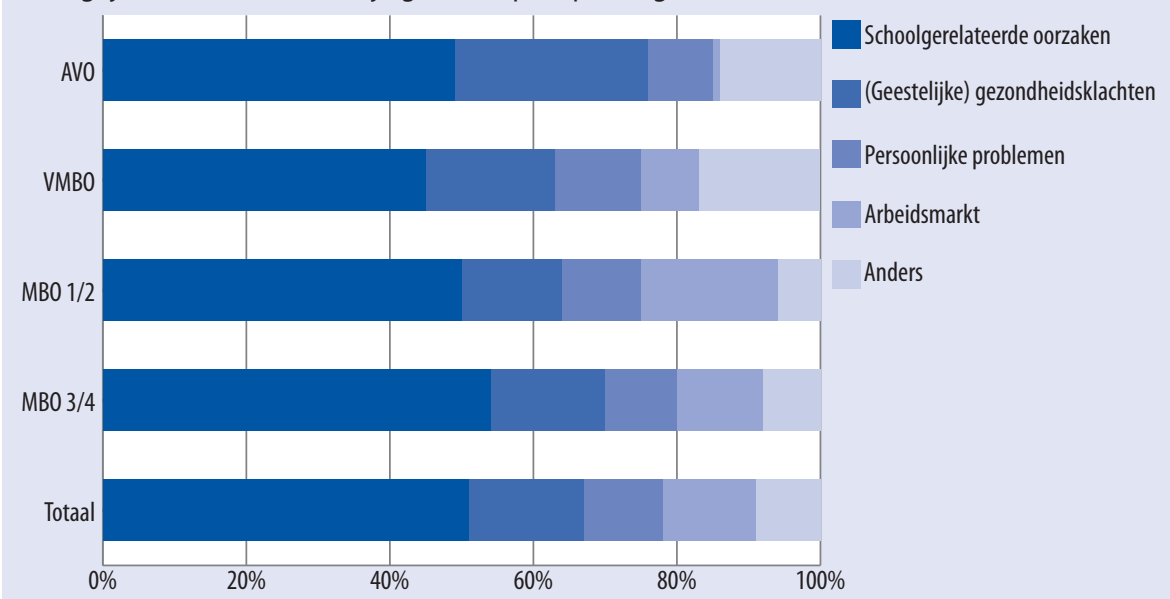

Bron:VSV-Monitor 2012 (ROA)

- Net als in eerdere metingen is 'schoolgerelateerde oorzaken' de vaakst genoemde belangrijkste reden voor de voortijdige uitval. Gaf echter in de meting van 2010 nog $41 \%$ van de respondenten aan te zijn gestopt vanwege schoolgerelateerde oorzaken (45\% in de meting van 2011), in de huidige meting is dit percentage gestegen naar $51 \%$. Deze stijging van ongeveer $5 \%$-punt is terug te zien op alle opleidingsniveaus.

- Kijkend naar het totaal, zien we dat de (geestelijke) gezondheidsklachten op de tweede plaats staan wat betreft de vaakst genoemde belangrijkste redenen voor voortijdige uitval. Met name in het AV0 $(27 \%)$ is het percentage respondenten dat aangeeft te zijn gestopt vanwege deze reden relatief hoog.

- $\quad 0 p$ alle opleidingsniveaus worden persoonlijke problemen door ongeveer een op de tien respondenten als belangrijkste reden genoemd.

- lets meer dan een op de tien respondenten geeft aan dat een arbeidsmarkt gerelateerde reden de belangrijkste reden was voor de voortijdige uitval. Net als voorgaande jaren wordt deze reden met name vaak genoemd door de respondenten van het MBO. 


\subsection{Arbeidsmarkt: Kans op werk ${ }^{12}$}

In het vervolg van dit hoofdstuk gaan we nader in op de intrede van de recent gediplomeerden op de arbiedsmarkt. Hierbij kijken we allereerst naar de kans op werk (paragraaf I.IO). In de volgende paragrafen komen vervolgens onder andere het dienstverband en de carrièremogelijkheden van de gevonden functies aan bod (paragraaf I.II) als ook de aansluiting tussen de gevolgde opleiding en het werk (paragraaf I.I2) en de beloning (paragraaf I.I3). De cijfers in dit hoofdstuk zijn gebaseerd op de schoolverlatersonderzoeken die in 2012 hebben plaatsgevonden. Dit betekent dat de respondenten in de tweede helft van 2012 de vragenlijst hebben ingevuld. Aangezien het gaat om gediplomeerden van het studiejaar 20I0/20II hebben zij die op zoek zijn gegaan naar passend werk ongeveer een jaar eerder, medio 20II, de arbeidsmarkt betreden.

\section{Figuur 1.14}

Economische groei Nederland, 2009-2012 (\% ten opzichte van dezelfde periode van het voorafgaande jaar).

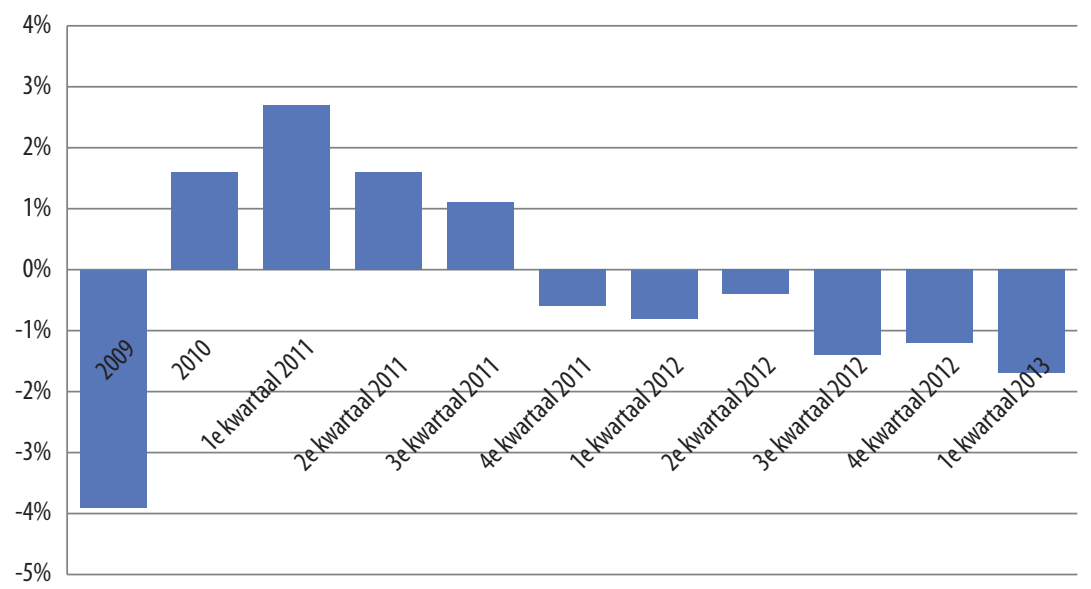

Bron: CBS, Statline

In de afgelopen jaren is er sprake van een economische crisis. Zowel in 20II, op het moment van de arbeidsmarktintrede, als in 2012 is er in Nederland sprake van een afnemende en zelfs negatieve economische groei (zie figuur.I.I4). Het spreekt voor zich dat het met name voor pas afgestudeerde schoolverlaters hierdoor niet alleen lastig is om werk te vinden maar ook lastig is om werk te houden. De gevolgen van een economische crisis gaan verder dan het alleen vinden van werk. Niet alleen is het lastiger om passend werk te vinden, dat wil zeggen werk dat wat niveau en richting betreft aansluit bij het diploma, maar ook de zoekduur zal er negatief door beïnvloed worden. Daarnaast kunnen er verdringingsverschijnselen optreden waardoor degenen met de laagste opleidingsniveaus meer moeite zullen hebben met het vinden van werk. Ook zal de crisis van invloed zijn op de arbeidsvoorwaarden zoals beloning en het aandeel vaste aanstellingen.

I2. De analyses omtrent de arbeidsmarktintrede beperken zich tot de groep gediplomeerden van het $\mathrm{MBO}$ en de afgestudeerden van het HBO. 


\section{Figuur 1.15}

Jeugdwerkloosheid Nederland en omringende landen in 2012 (\%)

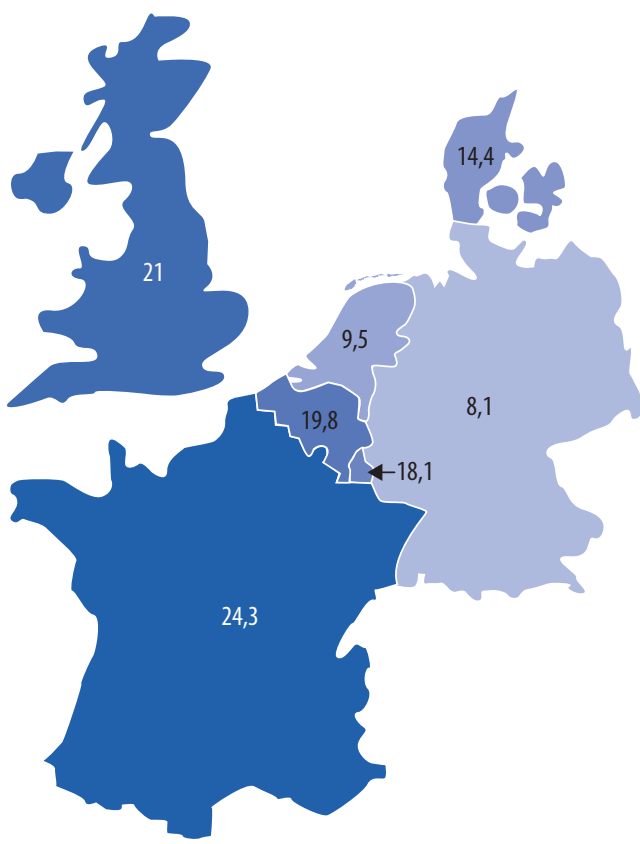
Duitsland
Nederland
Denemarken
Luxemburg
België
Engeland
Frankrijk

Bron: International Labour Organization (ILO)

Een economische crisis beperkt zich niet tot arbeidsmarkteffecten alleen. Ook zal de beslissing die recent afgestudeerden moeten maken met betrekking tot het wel of niet gaan volgen van vervolgonderwijs nog belangrijker worden dan die al was, iets waar ook overheden de afgelopen jaren al op inspelen. Zo is het kabinet onlangs weer gestart met het 'School-Ex programma' om leerlingen zo veel mogelijk te begeleiden bij het maken van een juiste studiekeuze en te voorkomen dat men te snel kiest voor de arbeidmarkt.

De economische crisis beperkt zich niet tot alleen Nederland maar is ook internationaal een groot probleem. Zo was in 2012 de jeugdwerkloosheid ${ }^{13}$ in Nederland weliswaar inmiddels opgelopen tot $9,5 \%$ maar in vergelijking met de meeste van de ons omringende landen nog relatief laag (zie figuur.I.I5). In landen die extra zwaar door de eurocrisis getroffen worden zoals Spanje en Griekenland ligt de jeugdwerkloosheid zelfs boven de $50 \%$. De cijfers in het vervolg van dit hoofdstuk zullen dan ook in het licht van deze economische crisis gezien moeten worden.

I3. De internationale definitie van (jeugd-)werkloosheid wijkt wat af van onze nationale defintie: mensen die tussen de I en de I2 uur werken behoren volgens deze internationale definitie niet tot de werklozen. De leeftijdsgrens is 15 tot 24 jaar. 


\section{Box $\mathrm{B}_{3}$}

Definitie van werkloosheid

In deze rapportage worden werkloosheidscijfers op basis van een tweetal definities gepresenteerd. Figuur 1.15 presenteert werkloosheidscijfers op basis van de internationale afbakening van de werkzame en werkloze beroepsbevolking volgens de richtlijnen van de International Labour Organization (ILO):

- De internationale definitie van de werkzame beroepsbevolking luidt als volgt: Alle personen die gedurende een nader vastgesteld periode (op een of andere manier) betaald werk hadden onafhankelijk van het aantal uren dat zij per week werkzaam waren.

- De internationale definitie van de werkloze beroepsbevolking luidt als volgt: Alle personen die gedurende een nader vastgestelde periode zonder werk waren en tegelijkertijd beschikbaar waren voor werk, onafhankelijk van het aantal uren dat zij beschikbaar zijn.

De cijfers gepresenteerd in de andere tabellen en figuren van deze rapportage volgen de nationale definitie van de werkzame en werkloze beroepsbevolking volgens de richtlijnen van het CBS:

- De nationale definitie van de werkzame beroepsbevolking luidt als volgt: Alle personen die gedurende een nader vastgestelde periode (op een of ander manier) betaald werk voor minimaal 12 uur per week hadden. Scholieren en studenten zijn daarbij uitgezonderd.

- De nationale definitie van de werkloze beroepsbevolking luidt als volgt: Alle personen die gedurende een nader vastgestelde periode zonder werk, dan wel met werk voor minder dan 12 uur per week, waren en tegelijkertijd beschikbaar waren voor werk. Scholieren en studenten zijn daarbij uitgezonderd.

Om te beginnen staan we stil bij de werkloosheid direct na afronden van de opleiding (voorjaar/zomer 20II). We kijken dus niet naar de werkloosheid op het moment van enquêteren maar op het moment van intrede op de arbeidsmarkt. Tabel I.Io presenteert daarbij de intredewerkloosheid, dat wil zeggen de zoekduur tot de eerst baan, in klassen.

Tabel 1.10

Intredewerkloosheid in klassen (\%)

\begin{tabular}{|l|r|r|r|r|r|r|r|r|r|r|}
\hline & BOL 1 & BBL 1 & BOL 2 & BBL 2 & BOL 3 & BBL 3 & BOL 4 & BBL 4 & HBO \\
\hline 0 mnd. & 73 & 89 & 77 & 92 & 79 & 91 & 85 & 97 & 70 \\
\hline $1-3$ mnd. & 9 & 2 & 9 & 5 & 10 & 5 & 7 & 1 & 14 \\
\hline $4-12$ mnd. & 12 & 5 & 12 & 2 & 9 & 3 & 7 & 2 & 12 \\
\hline$>12$ mnd. & 6 & 3 & 2 & 1 & 2 & 1 & 1 & 0 & 4 \\
\hline
\end{tabular}

Zie voor de onderliggende cijfers per opleidingssector tabel 15 in de Statistische Bijlage

De resultaten laten binnen het $\mathrm{MBO}$ direct een duidelijk verschil zien tussen de jongeren die een opleiding in de beroepsopleidende leerweg (BOL) en de jongeren die een opleiding in de beroepsbegeleidende leerweg (BBL) hebben afgerond. Terwijl van de jongeren met een MBO-BOL diploma op zak tussen de $73 \%$ (niveau I) en $85 \%$ (niveau 4 ) geen intredewerkloosheid rapporteren, is dit percentage onder de gediplomeerden van het BBL op alle niveaus aanzienlijk hoger (niveau r: 89\% en niveau 4: 97\%). Met andere woorden, de gediplomeerden van het BBL kennen een aanzienlijk hogere kans om rechtstreeks na 
het behalen van het diploma werk te hebben. ${ }^{14}$ De gediplomeerden van het MBO-BOL niveau I en 2 kennen niet verrassend de meeste moeite om op korte termijn werk te vinden. Van hen is dan ook I8\% (niveau I) dan wel I4\% ( niveau 2) ten minste 4 maanden werkloos voordat zij hun eerste baan vinden. Onder de jongeren die een MBO-BOL opleiding op niveau I hebben afgerond, dat wil zeggen een opleiding zonder startkwalificatie, is daarvan zelfs 6\%-punt langer dan I2 maanden werkloos. Een opvallend resultaat is dat de afgestudeerden van het $\mathrm{HBO}$ vergelijkbare moeite lijken te hebben met het vinden van werk als deze groep die zonder startkwalificatie op de arbeidsmarkt is toegetreden. Het hogere percentage HBO'ers dat tussen de I-3 maanden tussen afstuderen en eerste baan werkloos is geweest kan nog verklaard worden door het feit dat men wat langer heeft moeten zoeken naar geschikt, passend werk. Er mag echter worden verwacht dat dit in mindere mate zal gelden voor de goep HBO'ers die 4 maanden of langer hebben moeten zoeken omdat het op een gegeven moment beter is om niet passend werk (tijdelijk) te aanvaarden dan helemaal geen werk te hebben.

\section{Figuur 1.16}

Intredewerkloosheid > 3 maanden, naar gevolgde opleidingstype

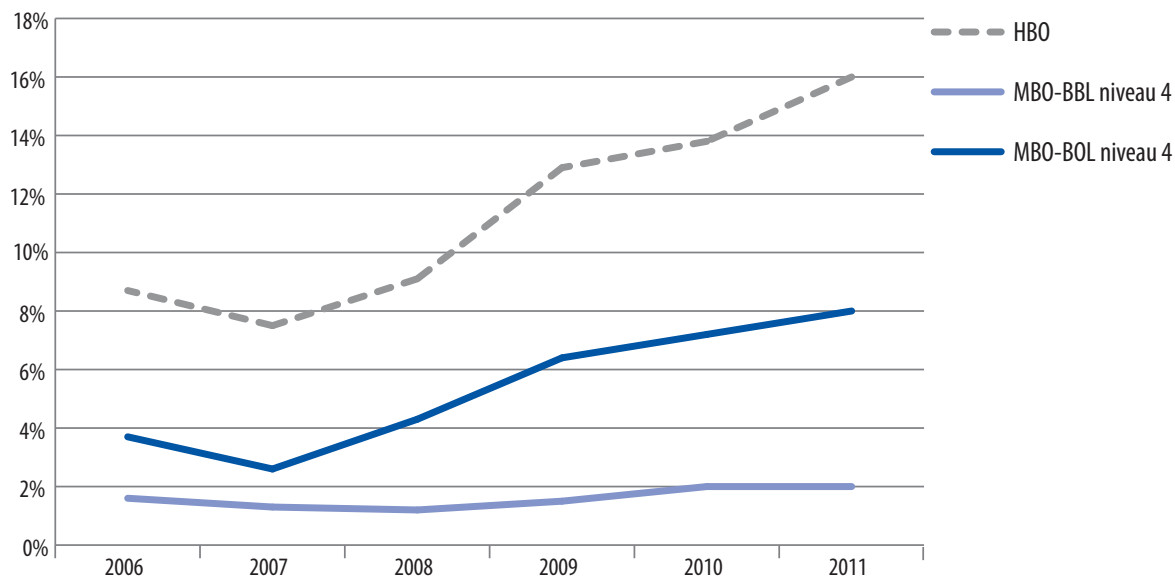

Bron: SIS (ROA), 2007-2012; Toelichting: het jaartal geeft het jaar van afstuderen weer

Dat de duur van de intredewerkloosheid deels sterk beïnvloed is door de conjunctuur laat figuur I.I6 duidelijk zien. Terwijl van de afgestudeerde HBO'ers van het studiejaar 2006 en 2007 gemiddeld zo'n $8 \%$ langer dan 3 maanden werkloos was voordat ze hun eerste baan vonden, steeg dit percentage in 2009 tot zo'n I3\% om, zoals tabel I.IO al liet zien, in 201 (meting 20I2) uit te komen op I6\%. De intredewerkloosheid onder de gediplomeerden van het $\mathrm{MBO}-\mathrm{BOL}$ niveau 4 laat een vergelijkbaar conjunctureel verloop zien, maar dan op een structureel lager niveau terwijl de duur van de intredewerkloosheid onder de gediplomeerden van het MBO-BBL niveau 4 blijkbaar niet beïnvloed is door

I4. Daarnaast geldt voor de gediplomeerden van het MBO-BOL dat het aandeel dat geen intredewerkloosheid kent in meting 2012 aanzienlijk lager ligt dan in meting 2008, dat wil zeggen voorafgaand aan de huidige economische crisis. 
de recente economische crisis. Hierbij dient echter opgemerkt te worden dat het effect van de economische crisis voor de BBL zich op een andere wijze manifesteert. Door de mindere economische bedrijvigheid zal het aantal BBL plaatsen in het bedrijfsleven onder druk komen te staan. Zo is de instroom in de BBL in schooljaar 2009/2010 met een 2.500 gedaald ten opzichte van het jaar er voor.

Voordat we nader stilstaan bij de werkloosheid op enquêtemoment onder de gediplomeerden en afgestudeerden van de verschillende onderwijssectoren laat figuur I.I7 alvast voor een drietal opleidingsniveaus (MBO-BOL, MBO-BBL en $\mathrm{HBO}$ ) de ontwikkeling in de werkloosheid tussen de meetjaren 2008 en 2012 zien. Het verloop van de werkloosheid op enquêtemoment volgt voor de gediplomeerden van het MBO-BOL en het HBO een vergelijkbare trend als de intredewerkloosheid. $\mathrm{Na}$ een relatief lage werkloosheid in $2008^{15}$ zien we een scherpe stijging in de werkloosheid onder de MBO-BOL gediplomeerden in 2009 (van $5.3 \%$ in 2008 naar $9.9 \%$ in 2009). Ook voor de gediplomeerden van het $\mathrm{MBO}-\mathrm{BBL}$ naam de kans op werkloosheid aanzienlijk toe (van $1 \%$ naar $3 \%$ ) en ook de HBO'ers werden getroffen met een stijgende werkloosheid (van 4\% naar 6\%). In 2010 was er een licht economisch herstel dat gepaard ging met een lichte daling in de werkloosheid onder de gediplomeerden van het MBO-BOL en een stabilisatie in de werkloosheid onder de gediplomeerden van het $\mathrm{MBO}-\mathrm{BBL}$ en de afgestudeerden van het $\mathrm{HBO}$. Sinds meting 2OII stijgt de werkloosheid onder de MBO-BOL gediplomeerden en de $\mathrm{HBO}$ afgestudeerden weer terwijl opvallend genoeg de werkloosheid onder de MBO-BBL gediplomeerden, evenals bij de intredewerkloosheid, niet verder lijkt te worden beïnvloed door de economische malaise.

\section{Figuur 1.17}

Werkloosheid op moment van enquête

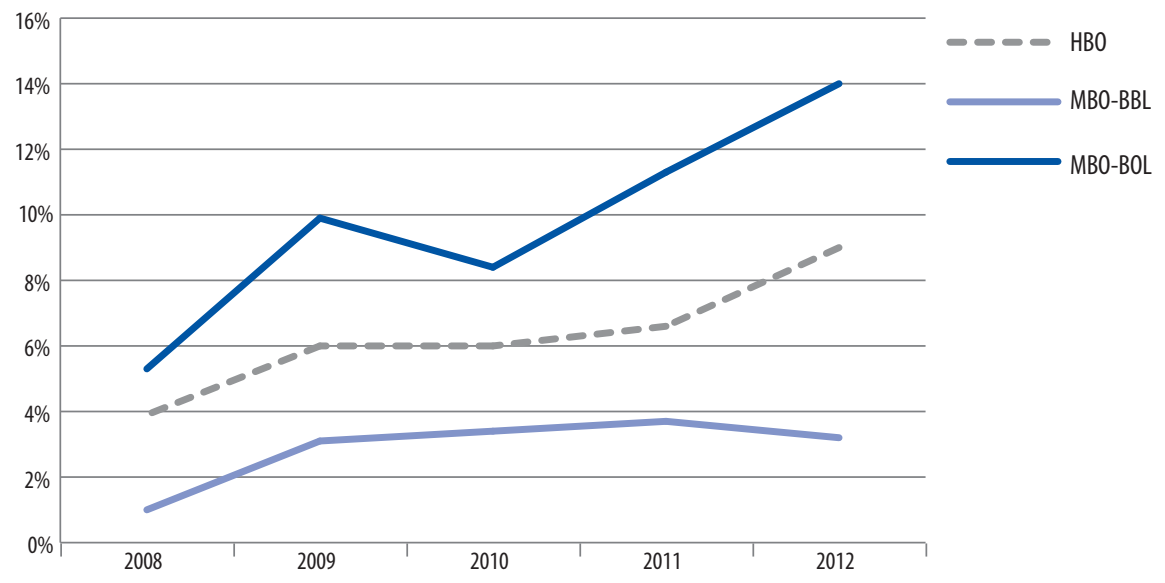

Bron: SIS (ROA), 2008-2012

15. De meting in het najaar van 2008 vond plaats voordat de eerste impact van de recente economische crisis op de Nederlandse arbeidsmarkt duidelijk werd. 


\section{Box B.4}

HBO: Duale en Deeltijd opleidingen

In dit hoofdstuk staan we uitgebreid stil bij de afgestudeerden van voltijd opleidingen van het HBO. Naast voltijd opleidingen biedt het HBO echter ook de mogelijkheid om opleidingen duaal dan wel in deeltijd te volgen. In het studiejaar 2010-2011 studeerden zo'n 12.500 jongeren van een deeltijd/duale opleiding af (ongeveer 10.500 deeltijders). In deze box presenteren we kort een aantal indicatoren omtrent de intrede op de arbeidsmarkt van deze groep jongeren. We doen dit aan de hand van een drietal aspecten van de intrede, namelijk'Voorbereiding,' 'Aansluiting' en 'Succes' en laten daarbij ter vergelijking ook de cijfers afkomstig van het onderzoek onder de gediplomeerden van de voltijd opleidingen nog eens zien.

De resultaten in tabel B.4 laten zien dat:

- De afgestudeerden van deeltijd/duale opleidingen zijn meer tevreden wat de voorbereiding op de arbeidsmarkt betreft. Met name de afgestudeerden van de duale opleidingen vonden hun studie een goede basis voor de arbeidsmarkt.

- De afgestudeerden van deeltijd/ duale opleidingen kennen wat de aansluiting met de richting betreft een betere match en oordelen daarom positiever over de algemene aansluiting tussen opleiding en functie.

- De afgestudeerden van deeltijd/duale opleidingen profiteren ervan dat zij een uitgebreidere werkervaring kennen (onder andere zijn zij al tijdens de opleiding werkzaam) wat zich vertaalt in een duidelijk kleinere kans op werkloosheid en een hogere bruto uurloon. Met name de deeltijd afgestudeerden kennen een hoog uurloon, daarentegen zijn zij wat minder positief over hun carrièremogelijkheden in hun huidige functie

Tabel B.4

\begin{tabular}{l|r|r|r}
\hline & Deeltijd & Duaal & Voltijd \\
\hline Voorbereiding & & & \\
\hline Goede basis om te starten op de arbeidsmarkt & $56 \%$ & $66 \%$ & $49 \%$ \\
\hline Goede basis om competenties en vaardigheden verder te ontwikkelen & $73 \%$ & $75 \%$ & $63 \%$ \\
\hline Aansluiting & & & \\
\hline Voldoende/goede aansluiting & & & \\
\hline Functieniveau past bij opleidingsniveau & $81 \%$ & $83 \%$ & $74 \%$ \\
\hline Functierichting past bij opleidingsrichting & $80 \%$ & $75 \%$ & $77 \%$ \\
\hline Succes & $85 \%$ & $90 \%$ & $78 \%$ \\
\hline Werkloosheid & & & \\
\hline Bruto uurloon (mediaan) & & & \\
\hline (heel) veel carrièremogelijkheden & $4,8 \%$ & $1,9 \%$ & $8,9 \%$ \\
\hline (zeer) tevreden met functie & $€ 18,90$ & $€ 16,40$ & $€ 13,30$ \\
\hline
\end{tabular}

Bron: HBO Monitor 2012

Voordat we nader ingaan op verschillen in de werkloosheid op basis van de gevolgde opleidingssector, kijken we eerst of er regionale verschillen in de werkloosheidscijfers zijn. Hiervoor presenteren we een drietal werkloosheidscijfers per provincie. In eerste instantie (figuur I.I8a) de algemene werkloosheid onder de Nederlandse beroepsbevolking. Daarnaast presenteren we de werkloosheid van recent gediplomeerden van het $\mathrm{MBO}$ (figuur I.I8b) en afgestudeerden van het $\mathrm{HBO}$ (figuur I.I8c). We kijken daarbij naar de woonplaats op het enquêtemoment en niet naar de provincie waar men de opleiding heeft gevolgd. 
Figuur 1.18a t/m 1.18c

Werkloosheid per provincie (\%)
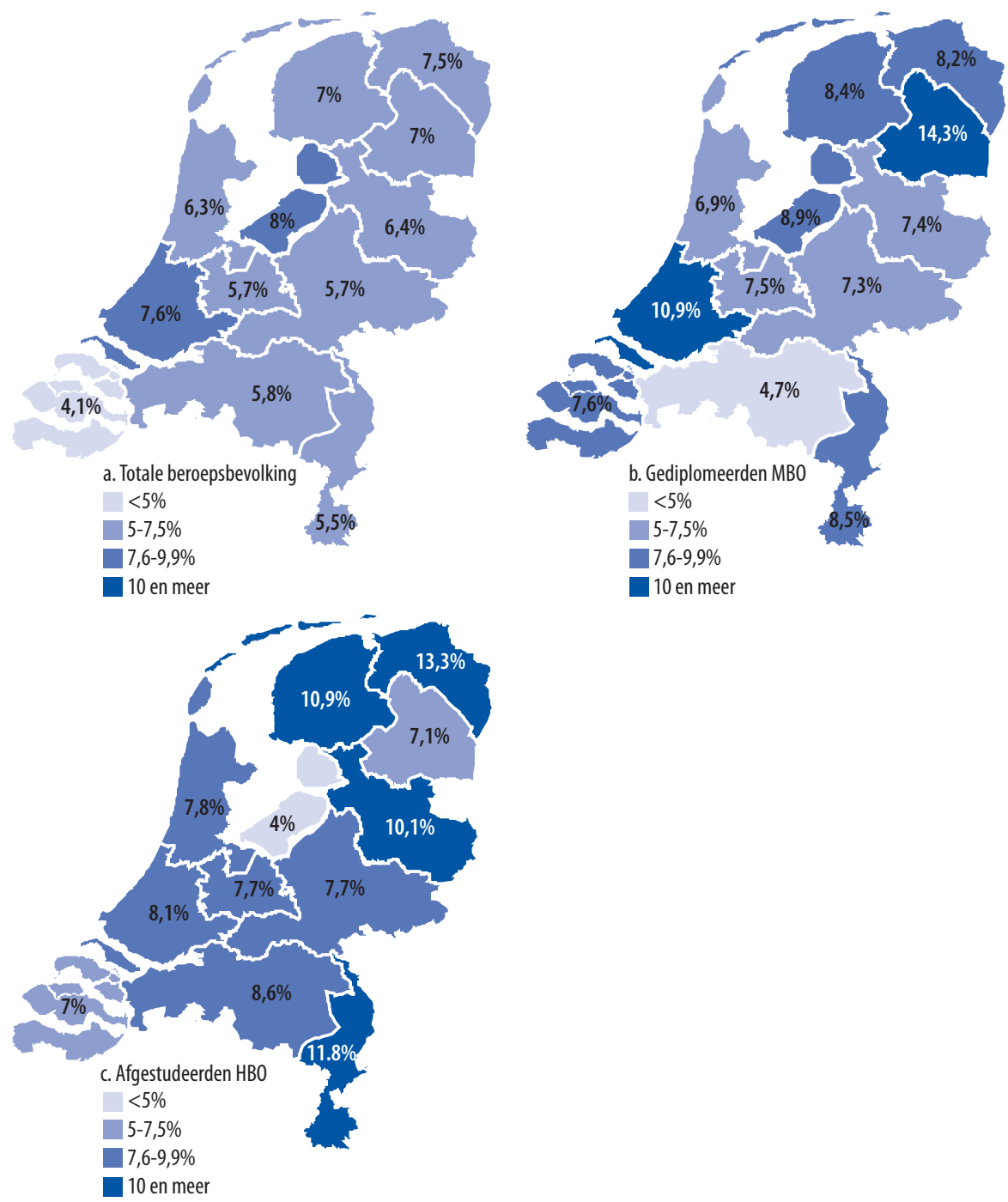

Bron: CBS, SIS (2012)

De werkloosheid onder de recent gediplomeerden en afgestudeerden ligt, niet verrassend, in de meeste provincies hoger dan de werkloosheid onder de totale beroepsbevolking. Uitzondering is de provincie Noord-Brabant waar de werkloosheid onder de recent gediplomeerden van het $\mathrm{MBO}$ net iets lager is dan de algemene werkloosheid. Drenthe kent onder de recent gediplomeerden van het $\mathrm{MBO}$ de hoogste werkloosheid (I4,3\%) terwijl deze provincie het juist goed doet wat de werkloosheid onder de afgestudeerden van het $\mathrm{HBO}$ betreft. De werkloosheid onder de $\mathrm{HBO}$ afgestudeerden is met name hoog in de 
noordelijke provincies en Limburg. Kijken we naar de twee groepen recente schoolverlaters als geheel, kennen de provincies Noord-Brabant, Zeeland, Utrecht en Gelderland de minste problemen.

Figuur I.I7 heeft al de ontwikkelingen in de werkloosheid onder de gediplomeerden van het $\mathrm{MBO}-\mathrm{BOL}$, het $\mathrm{MBO}-\mathrm{BBL}$ en het $\mathrm{HBO}$ in het algemeen geschetst. Tabel I.II laat nu per onderwijsniveau, en zover mogelijk binnen een onderwijsniveau per opleidingssector, in meer detail de werkloosheid onder de recent gediplomeerden en afgestudeerden in het najaar van 2012 zien. Ter vergelijking presenteren we onderaan de tabel ook per opleidingsniveau het gemiddelde werkloosheidspercentage uit meting 20II. Voor de twee opleidingstypes zonder predicaat 'startkwalificatie' (BOL en BBL niveau I) zien we dat het werkloosheidspercentage, ondanks de verdere krimp van de economie in 20I2, licht daalde tegenover het werkloosheidspercentage in 20II. Zeker onder de gediplomeerden van het MBO-BOL niveau I blijft de werkloosheid echter met 30\% buitensporig hoog.

Tabel 1.11

Werkloosheid op enquêtemoment (anderhalf jaar na diploma, \%)

\begin{tabular}{|l|r|r|r|r|r|r|r|r|r|}
\hline & BOL 1 & BOL 2 & BOL 3 & BOL 4 & BBL 1 & BBL 2 & BBL 3 & BBL 4 & HBO \\
\hline Landbouw & - & 21 & 14 & 16 & - & 7 & 2 & - & 11 \\
\hline Techniek & - & 17 & 22 & 6 & - & 2 & 0 & 0 & 8 \\
\hline Economie & - & 18 & 19 & 14 & - & 11 & 7 & 5 & 10 \\
\hline Gezondheidszorg & - & 21 & 3 & 6 & - & 3 & 1 & 0 & 4 \\
\hline Gedrag \& Maatschappij & $X$ & $X$ & 19 & 14 & $X$ & $X$ & 6 & 4 & 9 \\
\hline Taal \& Cultuur & $X$ & $X$ & $X$ & $X$ & $X$ & $X$ & $X$ & $X$ & 12 \\
\hline Onderwijs & $X$ & $X$ & $X$ & $X$ & $X$ & $X$ & $X$ & $X$ & 8 \\
\hline Totaal 2012 & 30 & 19 & 15 & 11 & 5 & 4 & 2 & 2 & 9 \\
\hline Totaal 2011 & 35 & 17 & 10 & 7 & 8 & 5 & 2 & 3 & 7 \\
\hline
\end{tabular}

Bron: SIS (ROA), 2011-2012; - aantal respondenten te klein; X sector komt niet in opleidingstype voor Zie ook tabel 14 in de Statistische Bijlage

Op alle andere MBO-BOL niveaus steeg de werkloosheid gemiddeld tussen $201 \mathrm{I}$ en 20I2: bij gediplomeerden van niveau 2 van $17 \%$ naar $19 \%$, bij de gediplomeerden van niveau 3 van IO\% naar $15 \%$ en bij de gediplomeerden van niveau 4 van $7 \%$ naar 1 I $\%$. Kijken we binnen het MBO-BOL naar de afzonderlijke onderwijssectoren dan zien we aan aantal duidelijke verschillen. De kans op werkloosheid is het laagst onder de gediplomeerden van de sector Gezondheidszorg (niveau 3 en niveau 4) en onder de gediplomeerden van de sector Techniek (niveau 4). Hiertegenover staat dat de gediplomeerden van de sector Gezondheidszorg op niveau 2 met 2I\% een bovengemiddelde kans op werkloosheid kennen en dat dit ook geldt voor de gediplomeerden van de sector Techniek op niveau 3 (22\%). De gediplomeerden van de sectoren Landbouw en Economie kennen op alle niveaus een gemiddeld of zelfs bovengemiddeld werkloosheidspercentage. Dit geldt ook voor jongeren die een opleiding in een van deze twee sectoren in het MBO-BBL dan wel het $\mathrm{HBO}$ hebben gevolgd. De opleidingen van de sector Economie in het MBO-BBL lijkt het hardst getroffen door de 
gevolgen van de economische crisis. Met werkloosheidspercentages van II\% (niveau 2), 7\% (niveau 3) en $5 \%$ (niveau 4) ligt het werkloosheidspercentage van deze opleidingen ruim boven het gemiddelde van het opleidingsniveau in de BBL.

Met uitzondering van de afgestudeerden van gezondheidszorgopleidingen (4\% werkloosheid) ligt de werkloosheid onder afgestudeerde HBO'ers van alle sectoren op minimaal $8 \%$. De hoogste werkloosheid vinden we daarbij onder de afgestudeerden van de sector Taal \& Cultuur (І2\%), Landbouw (II\%) en Economie (Іо\%). Voor alle drie sectoren betekent dit een stijging van minimaal $2 \%$-punt ten opzichte van de meting die in 20 II heeft plaatsgevonden. In de hoofdstukken 2 en 3 wordt nader ingegaan op de structurele verschillen in de werkloosheidspercentages.

\subsection{Arbeidsmarkt: Branches en dienstverband}

In deze paragraaf gaan we in op de branches waar de jongeren werken, hun aanstelling (flexibel, deeltijd) en de aard van hun dienstverband. Tabel I.I2 geeft om te starten een indicatie van de verwante doorstroom van het onderwijs naar de arbeidsmarkt als het gaat om de richting. De tabel laat per onderwijssector zien in welke branches de werkende $\mathrm{MBO}$ en $\mathrm{HBO}$ gediplomeerden op de arbeidsmarkt terecht komen. Vanwege de duidelijkheid zijn in de tabel alleen branches met een aandeel van minstens $5 \%$ van de respondenten opgenomen. Daarnaast worden per onderwijssector cijfers onder de $5 \%$ niet gepresenteerd.

Met $27 \%$ is de sector 'Gezondheids- en welzijnszorg', vergelijkbaar met afgelopen jaar de grootste werkgever onder de recent gediplomeerden en afgestudeerden. De sectoren 'Groot- en detailhandel; reparatie van auto's' (I5\%) en 'Industrie' (II\%) bieden eveneens aan meer dan IO\% van de gediplomeerde uitstroom werk. Kijken we nader naar de individuele onderwijssectoren dan zien we dat de werkgelegenheid zich voor een drietal onderwijssectoren (Onderwijs, Gezondheidszorg en Gedrag \& Maatschappij) toespitst op een tweetal economische sectoren. Werkt van de jongeren die een opleiding in de sector Onderwijs gevolgd hebben inderdaad $85 \%$ in het onderwijs, voor de gediplomeerden van de sectoren Gezondheidszorg en Gedrag \& Maatschappij vinden we rond de 80\% terug in de sector 'Gezondheidszorg en Welzijn'. De andere onderwijssectoren kennen een meer divers arbeidsmarktbeeld als het om de verdeling over de braches gaat. Zo werkt II\% van de jongeren uit de onderwijssector Landbouw in de sector 'Landbouw, Bosbouw, Visserij' maar vindt een aanzienlijk groter percentage werk in de sectoren 'Industrie'(27\%), 'Groot- en detailhandel, reparatie van auto's' ( $17 \%$ ) of de sector 'Verhuur van roerende goederen en overige dienstverlening' ( $15 \%)$. Driekwart van de gediplomeerden en afgestudeerden van de sector techniek vindt werk in een viertal sectoren: 'Industrie' (22\%), 'Bouwnijverheid'(22\%), 'Groot- en detailhandel, reparatie van auto's' ( $17 \%$ ) en 'Vervoer en opslag' ( $15 \%)$. De uitstroom van de onderwijssector 'Economie' kent het grootste aantal economische sectoren waarin minimaal $5 \%$ van de gediplomeerden en afgestudeerden terecht komt. De grootste werkgevers zijn daarbij de sector 'Groot- en detailhandel, reparatie van auto's' (26\%) en de sector 'Logies-, 
maaltijd- en drankverstrekking' (I5\%). Tot slot laat tabel I.I2 zien dat bijna een op de twee afgestudeerden van de sector Kunst, Taal en Cultuur in het 'Onderwijs' dan wel in de branche 'Cultuur, sport en recreatie' werk vindt.

Behalve het al dan niet hebben van een betaalde baan zijn werkzekerheid en de omvang van de werkzaamheden twee belangrijke indicatoren voor het succes van de transitie tussen onderwijs en arbeidsmarkt ${ }^{16}$. De twee kenmerken (flexibele en deeltijd aanstelling) die in tabel I.I3 gepresenteerd worden geven hiervan een indicatie. Onder een flexibele aanstelling verstaan we een aanstelling als uitzendkracht, oproepkracht e.d. of een tijdelijke aanstelling. Van een deeltijdaanstelling is sprake wanneer iemand een aanstelling van 32 uur of minder per week heeft.

Van alle bevraagde gediplomeerden en afgestudeerden heeft bijna 50\% een flexibele dan wel een deeltijd aanstelling. Het percentage jongeren met een flexibele aanstelling is daarmee ten opzichte van de meting in $201 \mathrm{I}$ met $4 \%$-punt gestegen. Tabel I.I3 laat zien dat er nogal verschillen zijn tussen de onderwijsniveaus ten aanzien van het aandeel van betaald werkende schoolverlaters met een flexibele aanstelling. In het MBO is daarbij wederom een duidelijke scheiding tussen de gediplomeerden van het MBO-BOL en de gediplomeerden van het MBO-BBL zichtbaar. In de eerste groep heeft tussen de $58 \%$ (BOL niveau 3) en $79 \%$ (BOL niveau I) een flexibele aanstelling terwijl dit in de tweede groep tussen de $17 \%$ (BBL niveau $\mathrm{I}$ ) en $33 \%$ (BBL niveau 2) is. Ook het percentage werkenden met een deeltijd aanstelling is onder de groep MBO-BOL gediplomeerden aanzienlijk hoger. Tussen de 50\% (niveau 4) en 69\% (niveau I) werkt in deeltijd, terwijl dit onder de gediplomeerden van het MBO-BBL tussen de $36 \%$ (niveau 3 ) en $51 \%$ (niveau 4) is. Zowel werkzekerheid als omvang van het werk ligt onder de afgestudeerden van het $\mathrm{MBO}-\mathrm{BOL}$ daarmee op een duidelijk lager niveau. Kijken we naar de onderliggende cijfers per opleidingssector (zie tabellen 17 en I8 in de statistische bijlage), zien we dat het percentage werkenden van het MBO met een flexibele aanstelling relatief klein is onder de gediplomeerden van de sector Gezondheidszorg zowel afkomstig uit het MBO-BOL als het MBO-BBL. Het laagste percentage met een flexibele aanstelling vinden we overigens onder de gediplomeerden van de sector Techniek op MBO-BBL niveau 4. Van hen werkt slechts $5 \%$ anderhalf jaar na behalen van het diploma met een flexibele aanstelling. Terwijl de gediplomeerden uit de MBO sector Gezondheidszorg relatief goed scoren wat de werkzekerheid betreft, zien we dat ze in de regel het hoogste percentage deeltijd aanstellingen kennen. Van de jongeren die een gezondheidszorgopleiding in het $\mathrm{MBO}$ hebben gevolgd werkt namelijk minimaal $76 \%$ (MBO-BBL niveau 4 ) in deeltijd.

Van de HBO afgestudeerden heeft $58 \%$ een flexibele aanstelling en werkt $38 \%$ in deeltijd. Relatief gezien het best scoren de afgestudeerden van de sector Techniek. Van hen werkt weliswaar ook bijna een op de twee met een flexibele aanstelling maar werkt 90\% in een voltijd dienstverband.

I6. Wat de omvang van de werkzaamheden betreft dient opgemerkt te worden dat aan deeltijd werken in principe ook een preferentie ten grondslag kan liggen. Met andere worden, deeltijd werken is pas een probleem als iemand full time zou willen werken. 


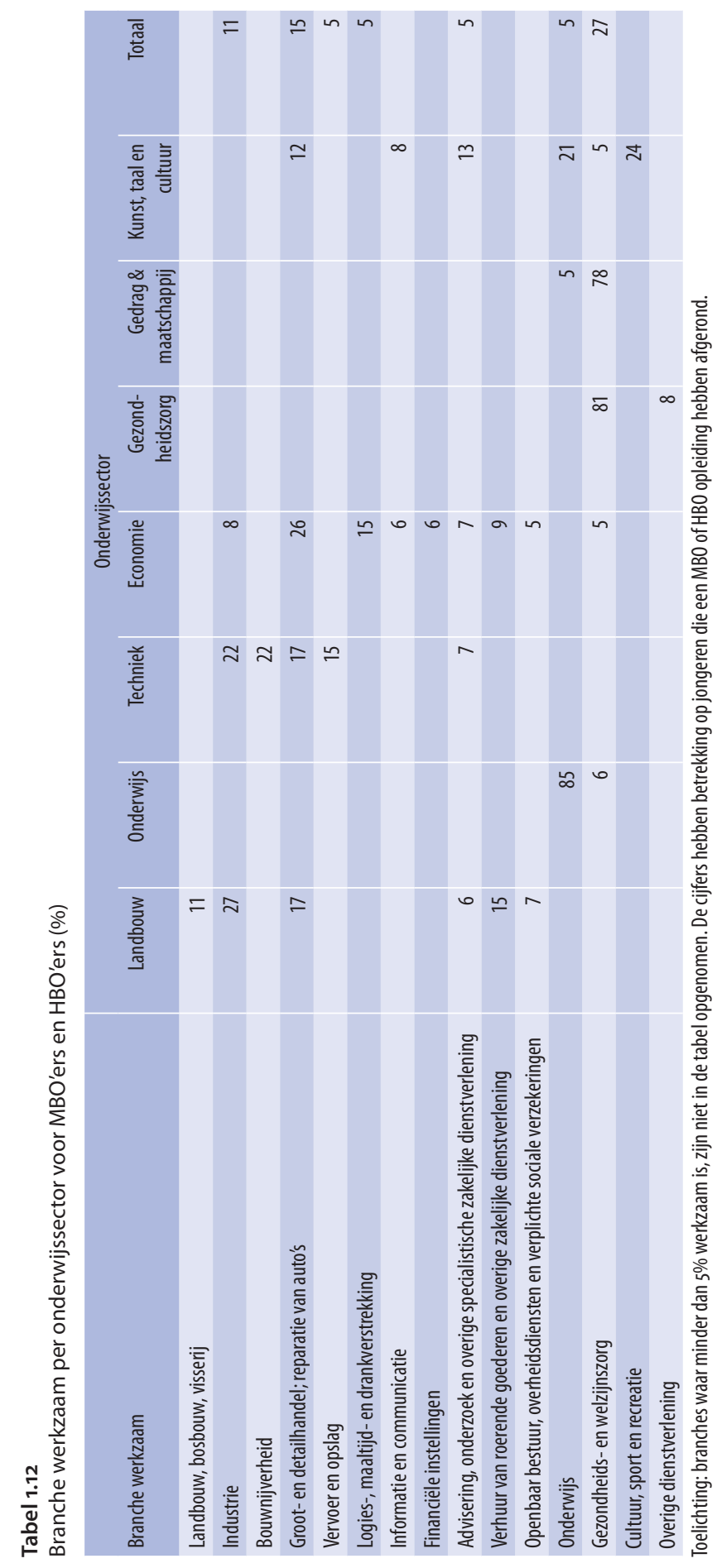


Tabel 1.13

Flexibele aanstelling en deeltijd aanstelling (\%)

\begin{tabular}{|l|r|r|r|r|r|r|r|r|r|r|r|r|}
\hline & BOL 1 & BOL 2 & BOL 3 & BOL 4 & BBL 1 & BBL 2 & BBL 3 & BBL 4 & HBO & Totaal \\
\hline Flexibele aanstelling & 79 & 65 & 58 & 59 & 17 & 33 & 31 & 18 & 58 & 48 \\
\hline Deeltijd aanstelling & 69 & 60 & 63 & 50 & 42 & 36 & 42 & 51 & 38 & 48 \\
\hline
\end{tabular}

Zie voor de onderliggende cijfers per opleidingssector tabellen 17 en 18 in de Statistische Bijlage

Figuur I.I9 presenteert tot slot de ontwikkelingen met betrekking tot deeltijd een flexibele aanstellingen tussen de metingen 2007 en 20I2. We onderscheiden hierbij in het MBO de niveaus I ('geen startkwalificatie') en de niveaus 2-4. Wat het werken in deeltijd betreft zien we voor alle drie onderscheiden groepen een stijgende trend. Was in 2007 nog tussen de $27 \%(\mathrm{HBO})$ en $39 \%$ (MBO 2-4) in deeltijd werkzaam, in de jaren daarna stijgt dit percentage gestaag tot $38 \%$ (respectievelijk $47 \%$ ). Wat het percentage met flexibele aanstelling betreft zien we dat MBO niveau I een uitzonderlijke positie en ontwikkeling kent. Terwijl de twee andere onderscheiden groepen namelijk een stijgende trend kennen (veroorzaakt door de economische crisis) daalt het percentage met een flexibele aanstelling onder de jongeren afkomstig van het MBO niveau I tussen 2007 en 2012 met zo'n $22 \%$-punt. Deze daling wordt veroorzaakt door een sterke daling in het percentage met een flexibele aanstelling onder de jongeren die een MBO-BBL niveau I opleiding hebben afgerond welke de stijging in flexibele aanstellingen onder de jongeren die een MBO-BOL niveau I opleiding hebben afgerond meer dan compenseert.

\section{Figuur 1.19}

Werkenden met een deeltijdaanstelling (a) en werkenden met een flexibele aanstelling (b) 2007-2012

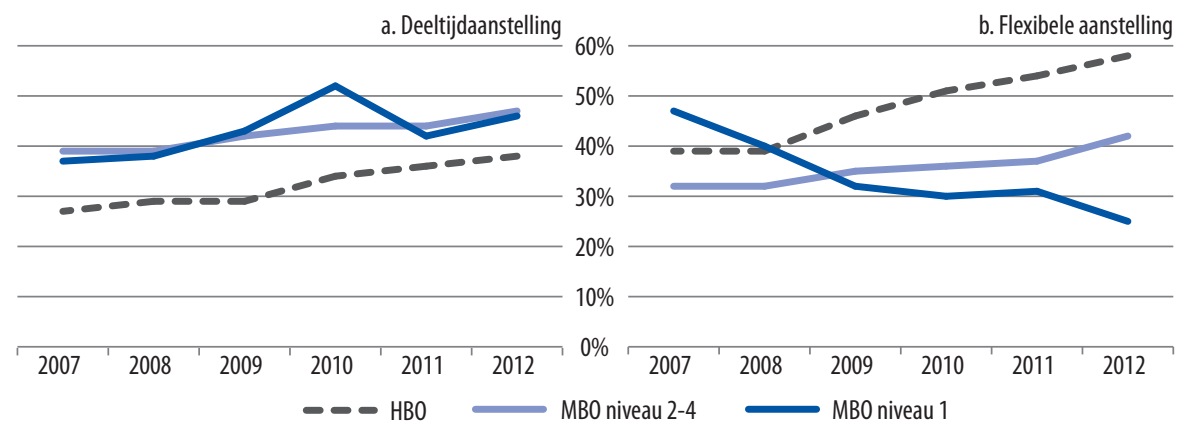

Tot slot van deze paragraaf staan we nog kort stil bij de precieze aard van het dienstverband dat de jongeren op moment van enquêtering hebben. Op basis van de data kunnen er een vijftal types van dienstverbanden onderscheiden worden: a) leer/arbeidsovereenkomst, b) uitzend- of oproepkracht, c) loondienst, d) werkzaam in bedrijf van ouders/ partner en e) eigen bedrijf/freelancer. Slechts I\% van de totale groep werkende gediplomeerden werkt in het bedrijf van de ouders/partner (dit type aanstelling komt relatief vaak voor bij jongeren die een opleiding in de sector Landbouw hebben afgerond) en $3 \%$ is werkzaam als freelancer of in het eigen bedrijf. Wat het werken als ZZP-er/zelfstandige of freelancer betreft kennen de afgestudeerden van de sector Kunst, Taal en Cultuur een 
uitzonderlijke positie. Van hen behoort namelijk 55\% tot deze groep. Deze twee groepen laten we dan ook in figuur 1.20 buiten beschouwing.

Het meest voorkomende dienstverband is zonder twijfel het reguliere werken in loondienst. Met uitzondering van de werkende gediplomeerden van MBO-BOL niveau I werkt op alle onderscheiden niveaus meer dan de helft van de jongeren in loondienst. Van de jongeren afkomstig van het MBO-BOL niveau i kent bijna 40\% een 'leer/arbeidsovereenkomst? Deze vorm van dienstverband komt daarnaast relatief vaak voor onder jongeren van het MBO-BOL niveau 2 ( $19 \%$ ) en bij zo'n $20 \%$ van de MBO-BBL gediplomeerden van niveau 2 en 3 . Het percentage dat werkt als 'uitzend-, oproepkracht' is onder de werkende gediplomeerden van het MBO-BOL niveau 2 het hoogst namelijk $13 \%$. Daarnaast kent ook het MBO-BOL niveau 3 (I2\%) en het $\mathrm{HBO}$ (9\%) een relatief hoog percentage dat werkzaam is als uitzend- dan wel oproepkracht.

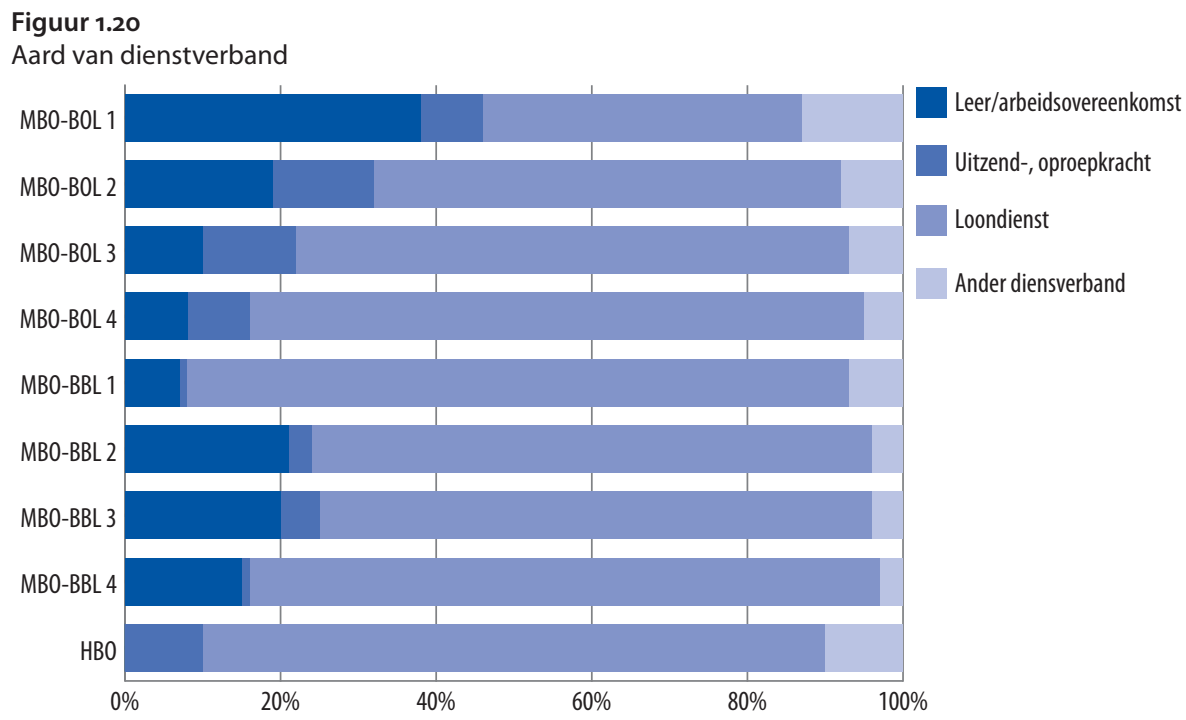

Zie voor de onderliggende cijfers per opleidingssector tabel 19 in de Statistische Bijlage

\subsection{Arbeidsmarkt: Aansluiting tussen werk en opleiding}

De kwaliteit van het gevonden werk wordt voor een belangrijk deel bepaald door de mate waarin men werkt in een functie die zowel wat richting als wat niveau betreft aansluit bij de gevolgde opleiding. Alhoewel opleidingen verschillen als het gaat om de mate waarin men studenten opleidt voor specifieke beroepen (bijvoorbeeld HBO lerarenopleidingen) of voor een wat breder beroepenveld (bijvoorbeeld HBO bedrijfseconomie) zal in het algemeen de aansluiting beter zijn naarmate men werk heeft dat dichter bij de gevolgde studierichting ligt. Er mag met andere woorden aangenomen worden dat de tijdens de 
studie verworven kennis en vaardigheden beter tot zijn recht komen in passende beroepen dan in minder passende beroepen.

Om deze aansluiting in kaart te brengen hebben we de groep werkzame schoolverlaters in een viertal groepen verdeeld waarbij gekeken is of men in de eigen/verwante richting werkt en of men daarnaast op minimaal het eigen opleidingsniveau werkt. Deze groepen zijn:

- werkzaam in een functie die zowel qua niveau als qua richting perfect bij de gevolgde opleiding past (kerndomein)

- werkzaam in een functie die qua niveau bij de opleiding past maar niet qua richting (horizontale mismatch)

- werkzaam in een functie die qua niveau onder het niveau van de opleiding ligt maar die wel qua richting bij de opleiding past (verticale mismatch)

- werkzaam in een functie die zowel qua niveau als qua richting niet bij opleiding past (dubbele mismatch)

Tabel 1.14

Aansluiting huidige functie naar niveau en richting (\%)

\begin{tabular}{|l|r|r|r|r|}
\hline & $\begin{array}{r}\text { Werkzaam in } \\
\text { kerndomein }\end{array}$ & $\begin{array}{r}\text { Horizontale } \\
\text { mismatch }\end{array}$ & $\begin{array}{r}\text { Verticale } \\
\text { mismatch }\end{array}$ & $\begin{array}{r}\text { Dubbele } \\
\text { mismatch }\end{array}$ \\
\hline MB0-B0L 1 & 63 & 21 & 3 & 12 \\
\hline MBO-BOL 2 & 52 & 17 & 10 & 21 \\
\hline MB0-BOL 3 & 60 & 10 & 12 & 18 \\
\hline MBO-BOL 4 & 69 & 11 & 6 & 15 \\
\hline MBO-BBL 1 & & & & 37 \\
\hline MBO-BBL 2 & 27 & 18 & 19 & 17 \\
\hline MBO-BBL 3 & 57 & 11 & 15 & 9 \\
\hline MBO-BBL 4 & 62 & 5 & 24 & 4 \\
\hline HBO & 77 & 5 & 14 & 13 \\
\hline
\end{tabular}

Behalve onder de MBO-BBL niveau I gediplomeerden werkt van alle onderwijstypes minstens de helft in een baan die wat niveau en richting betreft aansluit bij de gevolgde opleiding (zie tabel I.I4). De aanlsuiting is het beste onder de niveau 4 gediplomeerden en de HBO'ers. Zowel bij de BOL als de BBL gediplomeerden werken ongeveer 4 van de Io respondenten in een functie die alleen wat richting, alleen wat niveau of op geen van beide aspecten aansluit bij het behaalde diploma. Bij de BOL is er daarbij iets vaker sprake van een horizontale mismatch, bij de BBL'ers wat vaker van een verticale mismatch. Binnen de MBO-BOL hebben de niveau 2 afgestudeerden relatief het vaakst een niet aansluitende baan gevonden; $21 \%$ heeft een dubbele mismatch dat wil dus zeggen een baan die zowel wat richting als niveau betreft niet aansluit bij de gevolgde opleiding. Binnen de MBO-BBL zijn het de niveau 2 afgestudeerden die in negatieve zin uit de toon vallen, maar liefst $37 \%$ heeft een niet passende functie. Binnen de MBO-BOL zijn het met name de afgestudeerden van de gezondheidszorg opleidingen die goed terechtkomen: maar liefst 
$77 \%$ is werkzaam in het kerndomein. Van de BOL sector Landbouw gediplomeerden komen relatief veel mensen terecht in een functie met een dubbele mismatch te weten $24 \%$. Van de BBL gediplomeerden zijn het wederom de gediplomeerden uit de sector Gezondheidszorg maar ook de gediplomeerden uit de sector Gedrag en Maatschappij die in het kerndomein werken: zo'n acht van de tien werken in het kerndomein. Ook hier doen de landbouwers het relatief minder goed. Onder de afgestudeerden van het HBO zijn het met name de gediplomeerden van de sectoren Techniek en Gezondheidszorg (beide $77 \%$ ) en de HPO afgestudeerden (87\%) die in het kerndomein terecht komen.

Als aanvulling op de meer formele aansluiting naar niveau en richting is respondenten ook gevraagd hoe tevreden ze zelf zijn over de aansluiting tussen hun functie en hun gevolgde opleiding (zie figuur I.2I). In het algemeen zijn de BBL gediplomeerden net iets vaker tevreden over deze aansluiting. Van de BBL niveau 3 en 4 gediplomeeren vindt zelfs $84 \%$ de aansluiting goed of voldoende. De MBO-BOL en de $\mathrm{HBO}$ respondenten zijn wat minder tevreden. Van de BOL niveau 2 en 4 en de $\mathrm{HBO}$ uitstromers vindt zelfs een kwart dat de aansluiting matig of slecht is. Wanneer gekeken wordt naar alleen de mensen die in het kerndomein werken dan blijkt dat het oordeel over de aansluiting de afgelopen jaren heel stabiel is gebleven. Het is duidlijk dat degenen die in het kerndomein werken vaker tevreden zijn over de aansluiting dan de werkenden waarbij sprake is van een mismatch. Voor zowel het $\mathrm{MBO}$ als het $\mathrm{HBO}$ geldt dat wanneer er sprake is van een horizontale mismatch men minder tevreden is over de aansluiting dan wanneer er sprake is van een verticale mismatch. De richting lijkt in deze belangrijker te zijn dan het niveau van de functie.

\section{Figuur 1.21}

Aansluiting tussen opleiding en werk

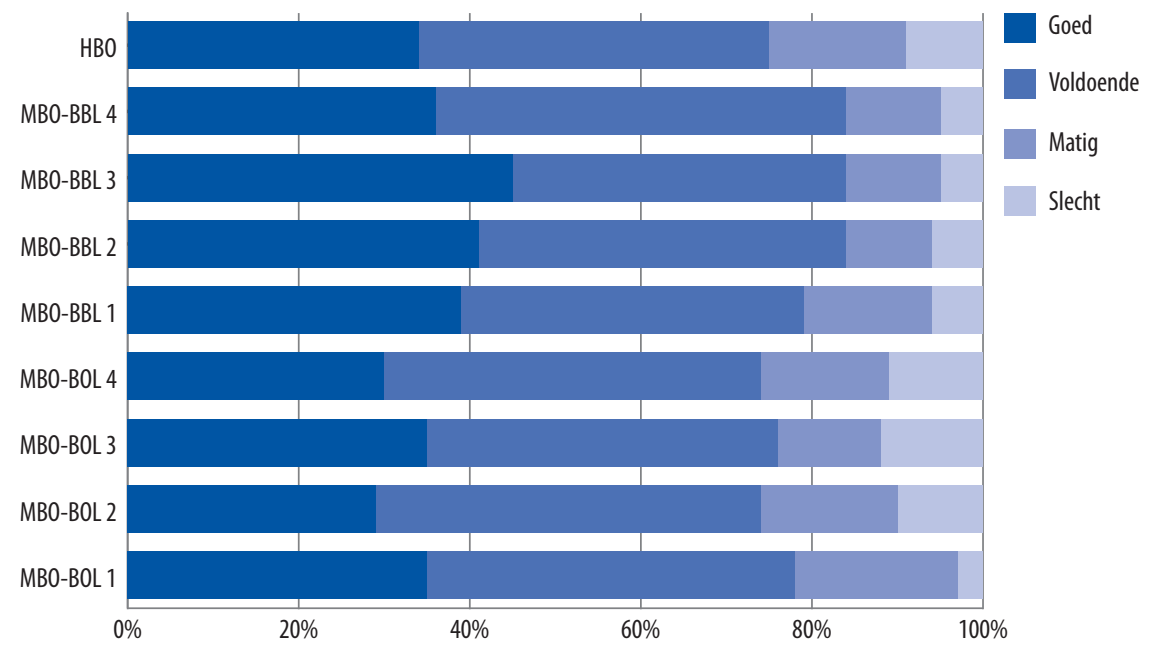

Zie voor de onderliggende cijfers per opleidingssector tabel 22 in de Statistische Bijlage 


\subsection{Arbeidsmarkt: Salaris}

Een belangrijke indicator van het rendement in economische termen van een opleiding op de arbeidsmarkt is zonder twijfel de beloning van de werkende gediplomeerden. Voordat we in tabel I.I5 zowel het gemiddeld bruto maandloon als het gemiddelde bruto uurloon presenteren, laat figuur I.22 eerst de ontwikkelingen tussen 2007 en 2012 zien wat de voor inflatie gecorrigeerde uurlonen betreft. De recente economische crisis heeft niet alleen invloed gehad op de kans op werk maar zeker ook op de ontwikkelingen wat het reële bruto uurloon betreft. Verdienden recent afgestudeerden van het HBO gemiddeld in 2008 nog zo'n I4,70 Euro bruto per uur, in 2012 is dit nog maar 13,30 Euro wat een daling van $9.5 \%$ is. Bij de werkende gediplomeerden van het $\mathrm{MBO}-\mathrm{BOL}$ zet de daling in het uurloon vooral na 2010 in. Tussen meting 2010 en meting 2012 zien we echter ook hier een sterke daling met $8 \%$. Vergelijkbaar met eerdere resultaten in dit hoofdstuk zien we dat de werkenden afkomstig van het MBO-BBL het minst last van de economische crisis hebben. Hun startsalaris blijft relatief constant in de periode 2007 tot en met 2012 en schommelt rond de 12 Euro.

Figuur 1.22

Voor inflatie gecorrigeerde uurlonen, 2007-2012 (€)

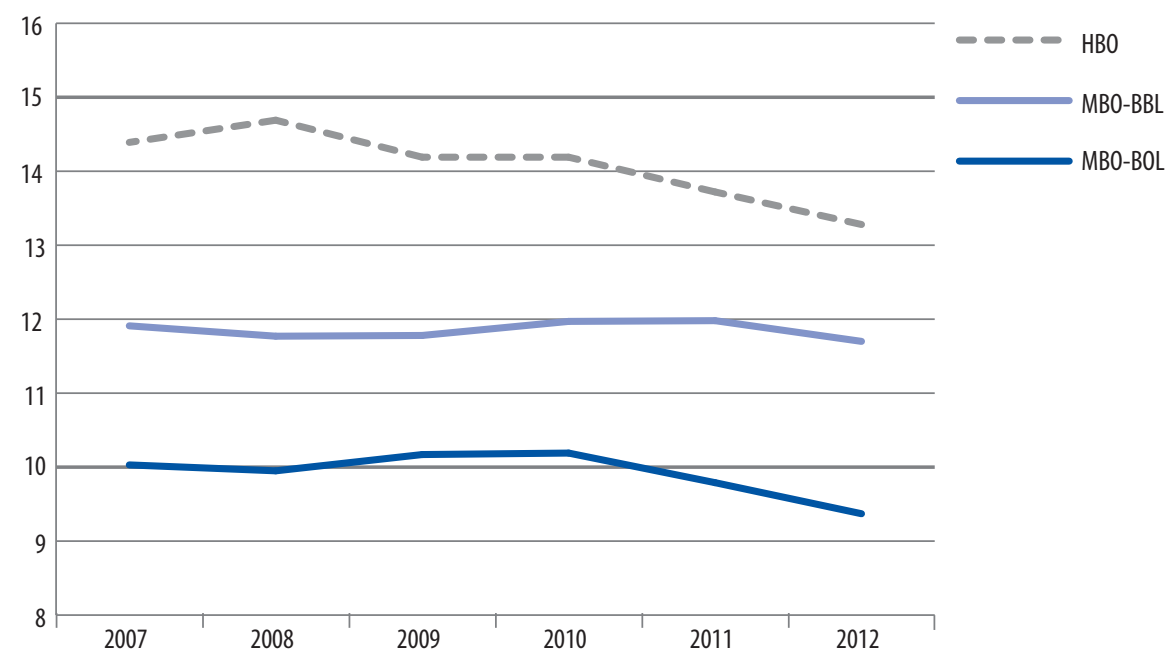

Omdat het gemiddelde bruto maandloon sterk van het aantal werkuren afhankelijk is, laten we in tabel I.I5 ook het gemiddeld aantal uren zien dat de gediplomeerden per week werkzaam zijn.

Met een gemiddeld bruto maandloon van Euro I.940 staan de afgestudeerden van het HBO niet verrassend bovenaan. Op uurloonbasis worden zij echter ingehaald door de gediplomeerden van het MBO-BBL niveau 4, die tegelijkertijd gemiddeld zo'n drie uur per week minder werken. Het hoogste bruto maandsalaris onder de afgestudeerden 
van het $\mathrm{HBO}$ vinden we voor de sector Techniek (Euro 2.345) gevolgd, echter al op aanzienlijke afstand, door de sector Economie (Euro 2.065) en de sectoren Landbouw en Gezondheidszorg (beide kennen een startsalaris van rond de 2.00o Euro). Op basis van het bruto uurloon zijn het de afgestudeerden van de HBO sector Gezondheidszorg die het hoogste startsalaris kennen (Euro 15,IO) gevolgd door de afgestudeerden van de sector Techniek (Euro I4.I5). Zowel op basis van het maandloon (Euro I.280) als op basis van het uurloon (Euro 9,65) verdienen de afgestudeerden van de $\mathrm{HBO}$ sector Taal en Cultuur, gegeven hun opleidingsniveau, relatief slecht.

De gediplomeerden van het MBO-BBL verdienen in de regel op alle niveaus en in alle opleidingssectoren een aanzienlijk hoger salaris dan hun studiecollega's van het MBO-BOL. Zo verdienen jongeren afkomstig van $\mathrm{MBO}-\mathrm{BBL}$ niveau I gemiddeld zo'n Euro I.50o per maand en loopt dit op tot bijna Euro I.90o onder de gediplomeerden van het MBO-BBL niveau 4. Onder de gediplomeerden van het MBO-BOL liggen de startsalarissen tussen Euro 945 en Euro I.380. ${ }^{17}$ Kijken we nader naar de onderliggende onderwijssectoren, is het beeld dat ontstaat relatief eenduidig en vergelijkbaar met het $\mathrm{HBO}$. Bovengemiddelde startsalarissen op basis van het gemiddeld bruto maandloon vinden we vooral voor de jongeren die een opleiding in de sector Techniek hebben gevolgd. Echter, aangezien zij in de regel een hogere gemiddelde werkduur kennen, verliezen zij op basis van het bruto uurloon hun koppositie aan de jongeren afkomstig van opleidingen in de Gezondheidszorg.

Tabel 1.15

Bruto uurloon $(€)$, bruto maandloon $(€)$ en aantal werkzame uren per week

\begin{tabular}{|l|r|r|r|}
\hline & Uurloon & Maandloon & Aantal uren \\
\hline BOL 1 & 7,20 & 945 & 28,1 \\
\hline BOL 2 & 7,85 & 1.020 & 30,4 \\
\hline BOL 3 & 9,20 & 1.175 & 29,8 \\
\hline BOL 4 & 10,05 & 1.380 & 32,1 \\
\hline BBL 1 & & & 32,6 \\
\hline BBL 2 & 10,90 & 1.505 & 34,5 \\
\hline BBL 3 & 10,55 & 1.560 & 33,6 \\
\hline BBL 4 & 12,10 & 1.735 & 32,2 \\
\hline HBO & 13,40 & 1.860 & 35,2 \\
\hline
\end{tabular}

Uurloon afgerond op 5 eurocent, Maandloon afgerond op $€ 5$; Zie voor de onderliggende cijfers per opleidingssector tabellen 18 en 23 in de Statistische Bijlage

17. Eerder onderzoek heeft aangetoond dat het verschil in salaris tussen de afgestudeerden van de twee MBO leerwegen ten minste gedeeltelijk verklaard kan worden door a) persoonlijke kenmerken (leeftijd, geslacht, etniciteit, sociale achtergrond en woonregio), b) gevolgde opleiding (sector, niveau, afstudeercijfer) en c) baankarakteristieken. 


\subsection{Tevredenheid met werk}

Tot nu toe zijn in dit hoofdstuk verschillende aspecten van de arbeidsmarkt en het gevonden werk aan de orde gekomen. Kans op werk, werkzekerheid, type aanstelling, aansluiting tussen opleiding en werk en onder andere het salaris vormen zeker belangrijke onderdelen van de transitie tussen onderwijs en arbeidsmarkt. Misschien echter nog belangrijker is de vraag of de recent gediplomeerden en afgestudeerden tevreden zijn met hun werk. We bespreken deze vraag aan de hand van een tweetal indicatoren, namelijk de algemene tevredenheid en de tevredenheid met de carrièreperspectieven die de functie biedt. De tweede indicator geeft daarbij een beeld van de loopbaanmogelijkheden die de functie biedt, een indicator die zeker voor recent gediplomeerden en afgestudeerden nogal van belang is. Tabel I.I6 laat zien dat op alle niveaus een meerderheid van de bevraagden tevreden is met de functie. Dit geldt (zie hiervoor tabel 24 in de Statistische Bijlage) ook voor alle onderliggende opleidingssectoren. Duidelijk bovengemiddeld tevreden zijn daarbij in de regel de afgestudeerden van de sectoren Techniek en Gezondheidszorg. Een in de regel relatief lage tevredenheid vinden onder de gediplomeerden en afgestudeerden van de sectoren Economie en Gedrag \& Maatschappij.

Wat de carrièreperspectieven betreft zijn de ondervraagden weliswaar kritischer, maar ook hier geldt, met uitzondering van de gediplomeerden van de lagere MBO-BBL niveaus, dat een krappe meerderheid de carrièreperspectieven als goed inschat. Onder de afgestudeerden van het $\mathrm{HBO}$ vinden we een tweetal sectoren (Onderwijs en Gedrag \& Maatschappij) waar minder dan $40 \%$ de carrièreperspectieven als goed aangeeft. ${ }^{18}$

Tabel 1.16

Tevredenheid met huidige functie en carrièreperspectieven (\%)

\begin{tabular}{|l|r|r|r|r|r|r|r|r|r|}
\hline & BOL 1 & BOL 2 & BOL 3 & BOL 4 & BBL 1 & BBL 2 & BBL 3 & BBL 4 & HB0 \\
\hline Tevreden met functie & 56 & 67 & 70 & 70 & 65 & 67 & 72 & 65 & 65 \\
\hline Goede carrièreperspectieven & 53 & 50 & 49 & 52 & 34 & 41 & 54 & 51 & 51 \\
\hline
\end{tabular}

Bron: SIS, 2012. Zie voor de onderliggende cijfers per opleidingssector tabellen 24 en 25 in de Statistische Bijlage

Tot slot laten figuur I.23 (algemene tevredenheid) en figuur I.24 (carrièreperspectieven) zien dat het oordeel van de werkende gediplomeerden en afgestudeerden inderdaad door de recente economische crisis is beïnvloed. Was voorafgaand aan de crisis (meetjaar 2008) nog tussen de $69 \%$ (MBO-BBL en $\mathrm{HBO}$ ) en $7 \mathrm{I} \%$ (MBO-BOL) tevreden met de functie, in de jaren 2009 tot en met $201 \mathrm{I}$ daalt dit percentage aanzienlijk om in 2012 wederom licht te stijgen. Dat de ontwikkelingen in de algemene tevredenheid sterk samenhangt met de carrièreperspectieven in de functie laat figuur I.24 zien. Zeker wat het MBO betreft zien we namelijk dat de algemene trend (stijgende tevredenheid vooraf aan de economische crisis, daling in de daaropvolgende jaren en lichte stijging in 20I2) ook wat de carrièreperspectieven zichtbaar is. Opvallend is echter dat de afgestudeerden van het $\mathrm{HBO}$ al vanaf 2007 een dalende tevredenheid met de carrièreperspectieven meldt.

I8. De vraag omtrent de carrièreperspectieven is niet gevraagd onder de afgestudeerden van de $\mathrm{HBO}$ sector Taal en Cultuur. 
HOOFDSTUK 1

Figuur 1.23

Tevreden met functie 2007-2012
Figuur 1.24

Goede carrièreperspectieven 2007-2012

$80 \%$

$70 \%$

$60 \%$

$50 \%$

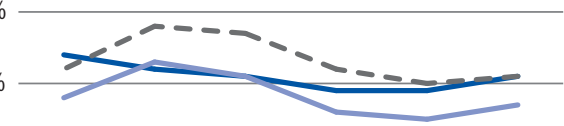




\section{Kwetsbare jongeren op de arbeidsmarkt: lessen van het MBO}

\subsection{Inleiding}

$\mathrm{Na}$ jaren van relatieve stabiliteit is de werkloosheid onder jongeren het afgelopen jaar sterk gestegen, en is zij met maar liefst $15 \%$ in januari 2013 het hoogst in dertig jaar (CBS, 20I3). Vooral jongeren zonder startkwalificatie (gediplomeerden van het VMBO of MBO-niveau I) kennen niet alleen structureel een hoge werkloosheid, maar worden tevens hard geraakt door laagconjunctuur. Dit onderstreept het belang van het halen van een startkwalificatie, en maakt de schoolverlaters zonder startkwalificatie een bijzondere groep, die afzonderlijk in ROA's vsv-factsheet 2012 worden onderzocht.

Maar ook gediplomeerden die het onderwijs verlaten met een startkwalificatie die direct voorbereidt voor arbeidsmarktparticipatie zijn kwetsbaar. Middelbaar opgeleiden hebben het ten opzichte van de hoger opgeleiden relatief moeilijk op de arbeidsmarkt, en ze worden harder geraakt door economische recessies. In dit hoofdstuk gaan we nader in op de gevolgen van de recente economische crisis voor het arbeidsmarktsucces van middelbaar opgeleide gediplomeerden met een startkwalificatie. Het hoofdstuk beoogt te laten zien welke MBO-gediplomeerden in het algemeen het meest kwetsbaar zijn op de arbeidsmarkt, en welke MBO-gediplomeerden kwetsbaarder zijn geworden tijdens de crisis. Daarbij wordt gekeken naar verschillen tussen de drie kwalificerende opleidingsniveaus, alsook tussen de gekozen leerwegen en de opleidingssectoren. Ook wordt een aantal aan persoonskenmerken gerelateerde factoren en enkele aan opleidingskenmerken gerelateerde factoren meegenomen in de analyses. We bezien of en in welke mate MBO'ers in het licht van hun kansen op de arbeidsmarkt kiezen voor alternatieve strategieën. Ook onderzoeken we of en in welke mate persoonlijke kenmerken van schoolverlaters bepalend zijn voor hun kansen op de arbeidsmarkt.

Dit hoofdstuk kent vier inhoudelijke paragrafen. In paragraaf 2.2 beschrijven we hoe de arbeidsmarktkansen van gediplomeerden van verschillende opleidingssectoren zijn veranderd gedurende de crisis. In paragraaf 2.3 onderzoeken we de mate waarin MBO'ers van verschillende niveaus alternatieve arbeidsmarktstrategieën kiezen. We bezien ook of de crisis ertoe heeft geleid dat meer gediplomeerden uit het MBO hun arbeidsmarktentree uitstellen en doorstuderen, en we beschrijven verschillen in doorstudeergedrag naar opleidingsniveau, -richting en leergang. Daarnaast onderzoeken we in deze paragraaf of de jongeren die werk hebben gevonden, een baan hebben aangenomen die niet past bij hun opleidingsniveau en -richting. 
In paragraaf 2.4 zoeken we naar oorzaken van werkloosheid van gediplomeerden uit het $\mathrm{MBO}$ tijdens de crisis. Hier onderzoeken we de invloed van de sociaaleconomische en etnische achtergrond van schoolverlaters op hun arbeidsmarktsucces, alsook de invloed van een aantal kenmerken van opleidingen.

In dit hoofdstuk wordt gebruik gemaakt van de gegevens uit het ROA schoolverlatersinformatiesysteem (SIS) voor de periode 2006-20I2. De gegevens zijn afkomstig uit de jaarlijkse ROA Schoolverlatersonderzoeken.

\subsection{Arbeidsmarktkansen van gekwalificeerde MBO'ers}

We beginnen dit hoofdstuk met een beschrijving van de veranderingen van de kansen op succes op de arbeidsmarkt van gediplomeerde schoolverlaters die het $\mathrm{MBO}$ met een startkwalificatie hebben verlaten. Daarbij belichten we drie aspecten die indicatief zijn voor verminderd arbeidsmarktsucces, te weten:

- Werkloosheid op enquêtemoment (ongeveer anderhalf jaar na behalen van het diploma)

- NEET (Not in Employment, Education, or Training) op enquêtemoment

- Langdurige intredewerkloosheid (langer dan I2 maanden)

We analyseren of en in hoeverre er verschillen bestaan tussen schoolverlaters met verschillende opleidingsrichtingen en leergangen, afkomstig uit verschillende regio's, en met verschillende persoonlijke en sociaaleconomische kenmerken, in de kansen op deze drie indicatoren van verminderd arbeidsmarktsucces. Er vanuit gaande dat jongeren bij hun opleidingskeuze veel minder flexibel waren in de keuze voor het opleidingsniveau dan in de keuze voor de opleidingsrichting of leergang, worden deze analyses telkens binnen de opleidingsniveaus uitgevoerd.

\subsubsection{Kans op werkloosheid}

Wellicht de meest voor de hand liggende indicator van verminderd arbeidsmarktsucces is werkloosheid. In figuur 2.I (opgedeeld in panels a t/m c) zien we per opleidingsniveau de werkloosheidstrend van de verschillende opleidingssectoren en leerwegen. ${ }^{\text {is }}$ Wat ten eerste opvalt in de figuur is dat de werkloosheid voor gediplomeerden van vrijwel alle MBO sectoren en leerwegen is toegenomen in crisis. De sectoren BBL Gezondheidszorg en BBL Techniek vormen hierop een uitzondering; de werkloosheid onder gediplomeerden van deze sectoren is zeer laag en lijkt nauwelijks door de crisis te worden beïnvloed. Voor alle niveaus geldt bovendien dat gediplomeerden met een BOL opleiding een veel hogere werkloosheid kennen dan gediplomeerden van de BBL.

19. Het aantal respondenten in de sectoren BBL Gezondheidszorg niveau 2 en BBL Landbouw niveau 4 is in sommige jaren te klein $(\mathrm{n}<2 \mathrm{O})$, waardoor de resultaten voor deze respondenten niet worden weergegeven. 


\section{Figuur 2.1}

Veranderingen in het werkloosheidspercentage van MBO-gediplomeerden, tussen 2007 en 2012, naar sector en leerweg
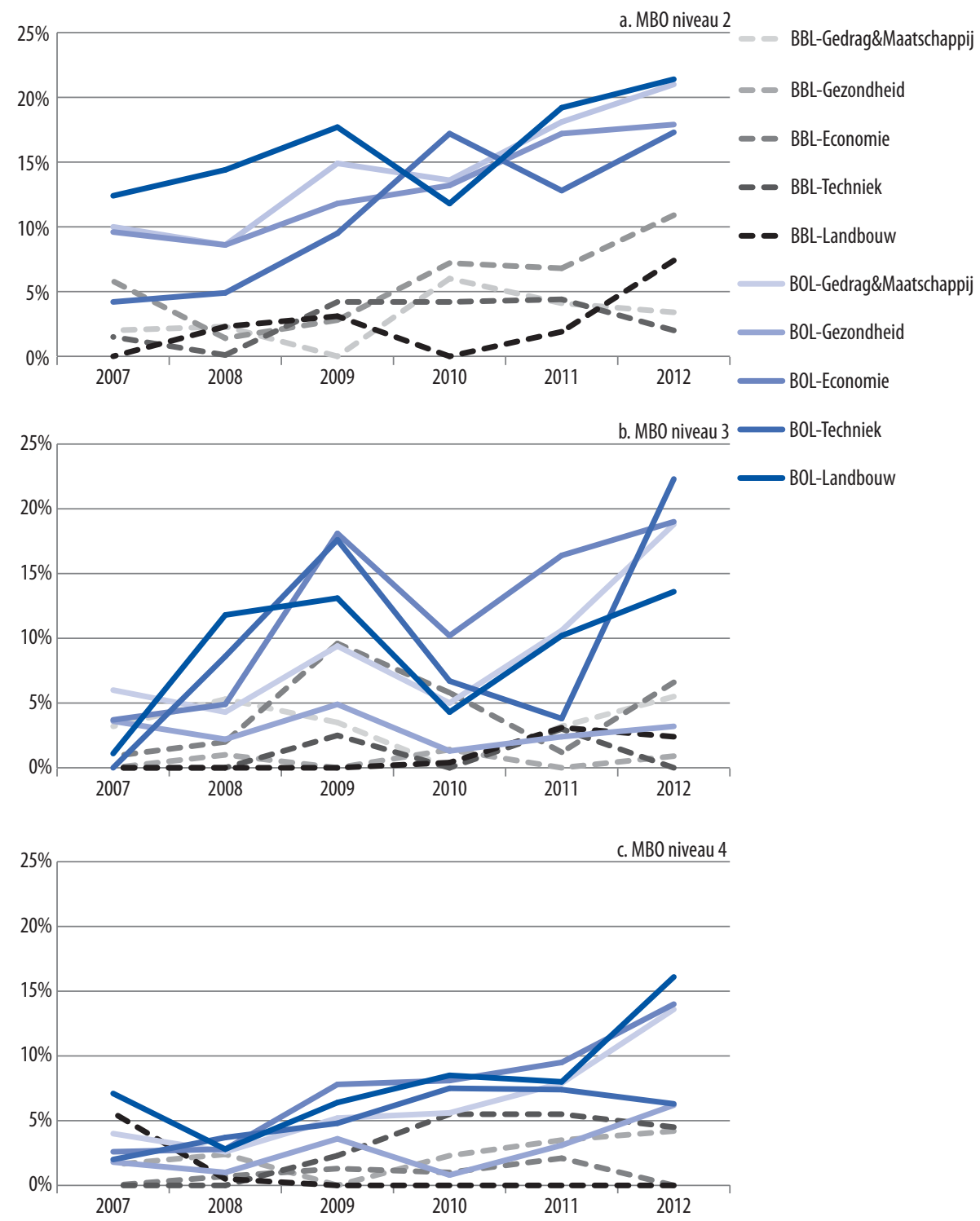

Bron: SIS (ROA), 2007-2012

Binnen het MBO-niveau 2 zien we dat gediplomeerden uit de MBO-BOL al vóór de crisis een kwetsbare groep vormden. Dit is door de crisis versterkt. Een BBL opleiding op 
dit niveau biedt echter nog steeds buitengewoon goede arbeidsmarktkansen, vooral in de sectoren Techniek en Gezondheidszorg.

Was vóór de crisis een opleiding op MBO-BOL niveau 4 niet zo zeer nadelig voor de kansen op werk, sinds de crisis is de werkloosheid onder deze jongeren sterk toegenomen. Onder deze BOL gediplomeerden in de sectoren Landbouw, Economie en Gedrag \& Maatschappij is de werkloosheid tussen $201 \mathrm{I}$ en $20 \mathrm{2} 2$ zelfs nog sneller toegenomen.

Hoewel de gediplomeerden van de BOL opleidingen die de arbeidsmarkt op gingen over het algemeen kleinere kansen hebben op een baan, hebben degenen met een MBO-BOL diploma in de sector Gezondheidszorg op niveau 3 of 4 relatief de grootste kans op een baan. BOL opleidingen in de sector Techniek doen het opvallend slecht op de lagere niveaus.

Tabel 2.I presenteert de resultaten van drie multivariate analyses. Voor de drie MBO-niveaus afzonderlijk wordt de werkloosheidskans van gediplomeerden in verband gebracht met een aantal kenmerken van de gevolgde studie, alsook met enkele persoonlijke achtergrondkenmerken.

Tabel 2.1

Logitanalyse op de kans op werkloosheid van gediplomeerden op de verschillende MBO-niveaus

\begin{tabular}{|c|c|c|c|}
\hline & MBO2 & MBO3 & MB04 \\
\hline \multicolumn{4}{|l|}{ Opleiding } \\
\hline \multicolumn{4}{|l|}{ BBL (ref.) } \\
\hline $\mathrm{BOL}$ & $0,733^{* * *}$ & $1,114^{* * *}$ & $1,129 * * *$ \\
\hline \multicolumn{4}{|l|}{ Economie (ref.) } \\
\hline Gedrag en Maatschappij & n.v.t. & $-0,257$ & $-0,110$ \\
\hline Landbouw & $-0,089$ & $-0,045$ & $0,431^{*}$ \\
\hline Techniek & $-0,104$ & $-0,306$ & 0,037 \\
\hline Zorg & $-0,468^{* * *}$ & $-1,251 * * *$ & $-0,790 * * *$ \\
\hline \multicolumn{4}{|l|}{ Crisiseffect } \\
\hline $\mathrm{Na} 2008$ (2007-2008 is ref.) & $0,750 * * *$ & $0,626 * * *$ & $0,919 * * *$ \\
\hline \multicolumn{4}{|l|}{ Persoonlijke achtergrond } \\
\hline Man (vrouwen zijn ref.) & $-0,465 * * *$ & $-0,428 * * *$ & $-0,368 * * *$ \\
\hline \multicolumn{4}{|l|}{ Autochtonen (ref.) } \\
\hline Niet westerse allochtonen & $0,830 * * *$ & $1,154 * * *$ & $0,573 * * *$ \\
\hline Westerse allochtonen & 0,438 & 0,267 & $0,603 * * *$ \\
\hline Leeftijd (gecentreerd) & $0,019 * * *$ & $0,024^{* * *}$ & $0,049 * * *$ \\
\hline \multicolumn{4}{|l|}{ Westen (ref.) } \\
\hline Noorden & $0,724^{* * *}$ & $0,769 * * *$ & $0,497^{* * *}$ \\
\hline Oosten & 0,105 & 0,109 & 0,116 \\
\hline Zuiden & 0,099 & 0,149 & $-0,047$ \\
\hline Constante & $-4,078 * * *$ & $-4,616^{* * *}$ & $-5,440 * * *$ \\
\hline
\end{tabular}

Noten: ${ }^{*} p<.05{ }^{* *} p<.01{ }^{* * *} p<.001$. Het gecentreerde leeftijdseffect moet worden geïnterpreteerd als effect van een jaar afwijken van de gemiddelde leeftijd

Bron: SIS (ROA), 2007-2012 
Zoals we reeds zagen in figuur 2.I, geldt voor alle niveaus dat gediplomeerden van MBO-BOL een grotere kans op werkloosheid hebben, maar dat gediplomeerden van de opleidingen in de sector Gezondheidszorg (in Niveau 2 alleen de BBL, op niveaus 3 en 4 zowel BOL als BBL) een kleinere kans op werkloosheid hebben. Ook wordt bevestigd dat - ten opzichte van de periode voor de crisis - de kans op werkloosheid sinds 2009 significant is toegenomen voor gediplomeerden van alle $\mathrm{MBO}$-niveaus.

Naast deze aan opleidingskenmerken gerelateerde factoren is het ook mogelijk dat persoonsgerelateerde factoren de kans op werkloosheid beïnvloeden. Uit de tabel is af te leiden dat, gecontroleerd voor opleidingsrichting en -sector, op alle opleidingsniveaus mannen een significant lagere kans op werkloosheid hebben dan vrouwen. Ook hebben niet-westerse allochtonen een hogere kans op werkloosheid dan autochtonen. Op MBO-niveau 4 hebben tevens de westerse allochtonen een hogere kans op werkloosheid. Voor alle opleidingsniveaus geldt dat hoe ouder de gediplomeerde is, hoe hoger diens kans op werkloosheid. De relatie tussen leeftijd en kans op werkloosheid is echter zeer zwak. Tot slot zien we dat de werkloosheid onder de MBO'ers die in het noorden van het land wonen het hoogst is.

Op basis van de voorgaande analyses is een viertal algemene conclusies te trekken:

- De werkloosheid onder MBO'ers is voor alle niveaus sinds de crisis sterk toegenomen.

- De werkloosheidskans van afgestudeerde MBO'ers is lager naarmate het niveau van hun opleiding hoger is.

- De werkloosheidskansen van gediplomeerden uit de BBL zijn over het algemeen lager dan de kansen voor gediplomeerden uit de BOL.

- De kansen op werk verschillen tussen de verschillende opleidingssectoren, waarbij gediplomeerden met een opleiding in de Gezondheidszorg relatief goede kansen hebben.

Het ligt in de lijn der verwachtingen dat de arbeidsmarktkansen daarnaast ook binnen sectoren sterk verschillen. Om werkloosheidskansen per opleidingsrichting te bepalen, zouden we een meer uitgebreide multivariate analyse moeten uitvoeren. Hier lopen we echter tegen zekere databeperkingen aan. De ROA Schoolverlatersonderzoeken bevatten voor een aantal opleidingen te weinig respondenten om een zinnige, te veralgemeniseren conclusie te trekken. Voor veel (met name kleinere) opleidingen ontbreekt het bovendien aan respondenten.

Om toch iets te kunnen zeggen over de mate waarin arbeidsmarktsucces van MBO-gediplomeerden te differentiëren is naar studierichtingen, beschrijven we in tabel 2.2 voor een aantal opleidingen de gemiddelde werkloosheid. De uitkomsten dienen slechts als indicatie van verschillen in werkloosheidskansen tussen opleidingen, en moeten hoegenaamd niet worden geïnterpreteerd als kwaliteitsoordeel over de opleidingen. Opgemerkt moet worden dat gediplomeerden van het leeuwendeel der opleidingen zo niet direct, dan toch erg snel na het behalen van hun diploma, een baan vinden. Merk tevens op dat we alleen de grotere opleidingen bespreken. 
Tabel 2.2

Opleidingen waarvan het verschil in het gemiddelde werkloosheidspercentage voor en na 2009 sterk is toegenomen (\%)

\begin{tabular}{|c|c|c|}
\hline Studierichting & Voor 2009 & 2009 en later \\
\hline \multicolumn{3}{|l|}{ MB02 } \\
\hline BOL Haven en vervoer & 0 & 19 \\
\hline BBL Bedrijfsadministratief & 0 & 18 \\
\hline BOL Energietechniek & 0 & 13 \\
\hline BOL Facilitaire dienstverlening & 3 & 14 \\
\hline BBL Meet- en regeltechniek & 0 & 10 \\
\hline BOL Bouw & 3 & 13 \\
\hline BOL Commercieel & 5 & 14 \\
\hline BOL Installatie-, service- en onderhoudstechniek & 0 & 9 \\
\hline BOL Reclame, presentatie en communicatie & 0 & 8 \\
\hline BOL Motorvoertuigen & 1 & 9 \\
\hline BBL Grond-, water en wegenbouw & 0 & 8 \\
\hline \multicolumn{3}{|l|}{ MB03 } \\
\hline BBL Wegvervoer & 0 & 22 \\
\hline BOL Houtbewerking en woninginrichting & 0 & 17 \\
\hline BBL Secretarieel & 3 & 14 \\
\hline BBL Opslag/magazijn & 0 & 10 \\
\hline BOL Commercieel & 0 & 9 \\
\hline BBL Machinebankwerken/verspanen & 0 & 9 \\
\hline BOL Veehouderij & 0 & 8 \\
\hline BOL Grond-, water- en wegenbouw & 0 & 7 \\
\hline BOL Beveiliging & 0 & 7 \\
\hline BOL Secretarieel & 0 & 11 \\
\hline \multicolumn{3}{|l|}{ MB04 } \\
\hline BBL Secretarieel & 0 & 19 \\
\hline BOL Voedingsmiddelentechnologie & 5 & 17 \\
\hline BBL Specialist Horeca, instellingskeuken en contractcatering & 0 & 9 \\
\hline BOL Maatschappelijke dienstverlening & 0 & 8 \\
\hline BOL Grond-, water- en wegenbouw & 0 & 8 \\
\hline BOL Bloemen- en tuincentrumbranche & 0 & 6 \\
\hline BBL Dierverzorging en veterinaire ondersteuning & 0 & 6 \\
\hline BBL Specialist Verpleging en verzorging & 0 & 6 \\
\hline BOL Specialist Houtbewerking en woninginrichting & 3 & 8 \\
\hline BOL Paardenhouderij en paardensport & 0 & 5 \\
\hline BOL Fotonica & 3 & 8 \\
\hline
\end{tabular}

De in tabel 2.2 gepresenteerde cijfers mogen niet worden geïnterpreteerd als een nationaal representatieve rangordening van opleidingen naar het arbeidsmarktsucces van hun gediplomeerden. Ze zijn bedoeld als exploratie van verschillen in arbeidsmarktkansen binnen sectoren, die met de eerder in dit hoofdstuk uitgevoerde analyses niet aan het licht te brengen zijn. In de tabel wordt voor de drie kwalificerende niveaus in het MBO de gemiddelde werkloosheid per studierichting gepresenteerd. We presenteren voor ieder 
niveau de Io opleidingen waarvan de gemiddelde werkloosheid van gediplomeerden sinds 2009 het sterkst is toegenomen.

Hoewel de resultaten voorzichtig moeten worden geïnterpreteerd, bieden de cijfers in tabel 2.2 een aantal interessante inzichten. De tabel maakt inzichtelijk dat de algemene conclusies zoals hiervoor getrokken, op in ieder geval twee punten nuancering behoeven. De eerste nuancering betreft de differentiatie naar sector. Vooraleerst blijkt dat de gemiddelde werkloosheidskansen inderdaad sterk naar opleidingen zijn gedifferentieerd. Ook de verandering van de gemiddelde kansen op werk verschillen sterk binnen sectoren, en dus tussen opleidingen. De gevolgen van de economische crisis zijn dan ook zeer verschillend voor verschillende opleidingsrichtingen.

Er is geen sprake van een herkenbaar patroon in de mate waarin opleidingen in verschillende bedrijfseconomische sectoren getroffen zijn door de crisis. We vinden voor alle niveaus dat de kansen op werk voor gediplomeerden van opleidingen uit de sector Techniek, Gedrag en Maatschappij, Economie en Landbouw sterk zijn verslechterd door de crisis.

Daarnaast blijkt ook dat het eerder geobserveerde onderscheid tussen gediplomeerden uit BBL en BOL nadere nuancering behoeft. Waar in het algemeen geldt dat schoolverlaters uit de BBL betere arbeidsmarktkansen hebben dan schoolverlaters uit een BOL-opleiding, zijn er ook in de begeleidende leerwegen opleidingen waarvan de gediplomeerden het relatief moeilijk hebben op de arbeidsmarkt.

Een voorbeeld voldoet om het belang van de nadere nuancering te illustreren. Waar in figuur 2.Ic bleek dat MBO-niveau 4 gediplomeerden in de sector Gezondheidszorg en de BBL in algemene zin een lage werkloosheidskans hebben, blijkt uit tabel 2.2 dat de werkloosheidskansen voor gediplomeerden uit de BBL opleiding Specialist Verpleging en Verzorging sterk zijn toegenomen sinds 2009.

\subsubsection{Kans om in en positie als NEET terecht te komen}

Een bijzondere groep schoolverlaters vormen de zogeheten NEETs: Not in Employment, Education or Training. Dit zijn schoolverlaters die niet studeren, geen trainingen volgen, zich niet op de arbeidsmarkt begeven, en zich ook niet op de arbeidsmarkt aanbieden. NEET-jongeren worden doorgaans gekwalificeerd als inactieve jongeren. Deze jongeren zijn later bijzonder kwetsbaar op de arbeidsmarkt, omdat hun re-integratiekansen erg laag liggen (OECD, 20I2). Door de economische crisis neemt het aantal NEETs in de meeste OECD-landen toe (OECD, 2012). De OECD (2012) laat zien dat het aantal NEETs in Nederland lager ligt dan in alle andere Europese landen, maar dat het aantal (net zoals in andere Europese landen) wel toeneemt. In figuur 2.2 wordt het percentage mannelijke MBO-gediplomeerden gepresenteerd dat ongeveer anderhalf jaar na afstuderen in een positie als NEET terecht is gekomen. Uit de figuur blijkt dat het aantal NEETs dat vanaf het $\mathrm{MBO}$ komt, niet trendmatig toe- of afneemt. 


\section{Figuur 2.2}

Mannelijke MBO-gediplomeerde NEETs, voor en tijdens de crisis

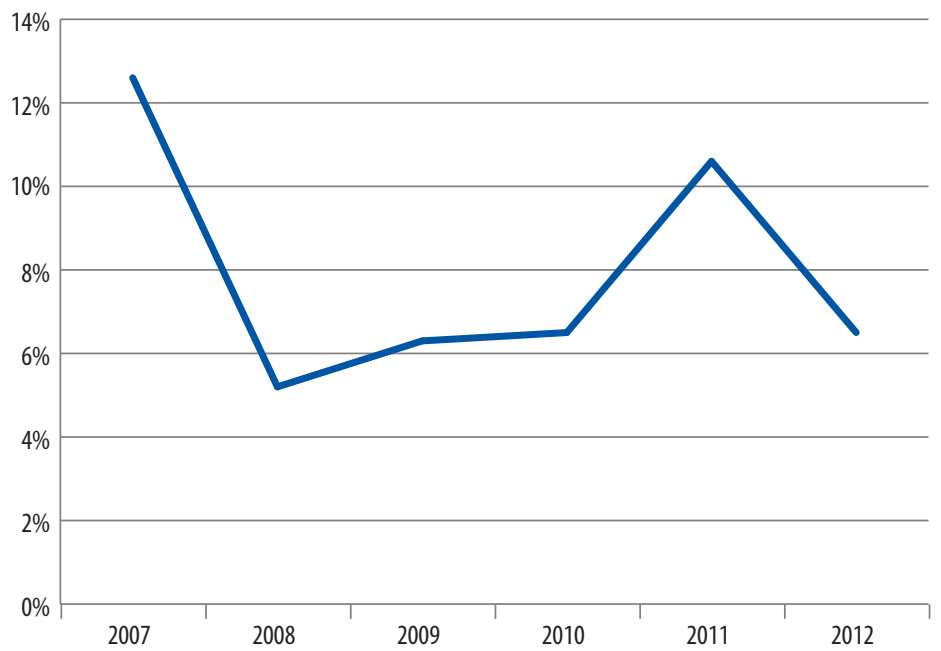

Bron: SIS (ROA), 2007-2012

Wederom wordt de indicator voor verlaagd arbeidsmarktsucces (in dit geval NEET) in drie multivariate analyses gerelateerd aan een aantal kenmerken van de gevolgde studie en persoonlijke achtergrondkenmerken (tabel 2.3).

Gecontroleerd voor periode-effecten, persoonlijke achtergrondkenmerken en overige opleidingskenmerken, hebben gediplomeerden van de BOL op alle niveaus een significant grotere kans om ongeveer anderhalf jaar na het behalen van het diploma in een positie als NEET terecht te komen. De opleidingsrichting heeft geen significante invloed op de kans op een positie als NEET.

Daarnaast zien we dat, hoewel er voor de totale groep MBO-gediplomeerden met een startkwalificatie geen sprake leek te zijn van een trendmatige toe- of afname, dat wel het geval is voor de MBO-gediplomeerden van niveaus 2 en 4 . Zij hebben tijdens de crisis een significant grotere kans om ongeveer anderhalf jaar na afstuderen in een positie als NEET terecht te komen dan voor de crisis.

Kijkend naar de persoon-gerelateerde factoren zien we dat NEET met name een verschijnsel is dat voorkomt in het westen van het land. Op alle niveaus geldt dat (gecontroleerd voor opleidingskenmerken, periode-effecten en overige persoonlijke achtergrondkenmerken) gediplomeerden die in het westen wonen een significant veel hogere kans op een NEET positie hebben dan schoolverlaters in de andere regio's. Verschillen in de sociaaleconomische herkomst van schoolverlaters of de status als immigrant kunnen geen verklaring bieden voor het relatief grote aantal NEETs in het westen van het land; zo laten aanvullende analyses zien. 
Tabel 2.3

Logitanalyse op de kans om NEET te zijn op enquêtemoment, van mannelijke gediplomeerden op de verschillende $\mathrm{MBO}$-niveaus

\begin{tabular}{|c|c|c|c|}
\hline & MBO2 & MBO3 & MBO4 \\
\hline \multicolumn{4}{|l|}{ Opleiding } \\
\hline \multicolumn{4}{|l|}{ BBL (ref.) } \\
\hline BOL & $0,604^{* * *}$ & $0,815^{* * *}$ & $0,512^{* *}$ \\
\hline \multicolumn{4}{|l|}{ Economie (ref.) } \\
\hline Gedrag en Maatschappij & n.v.t. & 0,085 & $-0,046$ \\
\hline Landbouw & 0,038 & $-0,299$ & 0,029 \\
\hline Techniek & 0,047 & $-0,203$ & $-0,039$ \\
\hline Zorg & 0,226 & $-0,131$ & $-0,243$ \\
\hline \multicolumn{4}{|l|}{ Crisiseffect } \\
\hline Na 2008 (2007-2008 is ref.) & $0,216^{*}$ & 0,284 & $0,295^{* *}$ \\
\hline \multicolumn{4}{|l|}{ Persoonlijke achtergrond } \\
\hline \multicolumn{4}{|l|}{ Autochtonen (ref.) } \\
\hline Niet westerse allochtonen & 0,130 & 0,318 & 0,135 \\
\hline Westerse allochtonen & 0,362 & 0,024 & 0,025 \\
\hline Leeftijd (gecentreerd) & $0,031^{* * *}$ & 0,015 & $0,026^{*}$ \\
\hline \multicolumn{4}{|l|}{ Westen (ref.) } \\
\hline Noorden & $-1,126^{* * *}$ & $-1,337^{* * *}$ & $-0,917^{* * *}$ \\
\hline Oosten & $-1,359 * * *$ & $-1,224 * * *$ & $-1,172^{* * *}$ \\
\hline Zuiden & $-1,478^{* * *}$ & $-1,440 * * *$ & $-1,187^{* * *}$ \\
\hline Constante & $-2,320 * * *$ & $-2,683 * * *$ & $-3,004^{* * *}$ \\
\hline
\end{tabular}

Noten: ${ }^{*} p<.05{ }^{* *} p<.01{ }^{* * *} p<.001$. Analyses enkel uitgevoerd op mannelijke gediplomeerden. Het gecentreerde leeftijdseffect moet worden geïnterpreteerd als effect van een jaar afwijken van de gemiddelde leeftijd

Bron: SIS (ROA), 2007-2012

\subsubsection{Kans op langdurige intredewerkloosheid}

Eerder onderzoek (ROA, 2009) heeft laten zien dat er een negatief verband bestaat tussen langdurige intredewerkloosheid en de arbeidsmarktkansen op latere leeftijd. We spreken van langdurige of structurele intredewerkloosheid wanneer iemand na behalen van het diploma meer dan 12 maanden werkzoekend is tot de eerste baan. Figuur 2.3 (a t/m c) laat per MBO-niveau de trend in langdurige intredewerkloosheid zien, uitgesplitst naar leerweg en opleidingssector.

Uit de figuur blijkt dat de langdurige intredewerkloosheid op alle MBO-niveaus voor de meeste opleidingssectoren onder de $5 \%$ blijft. Op MBO-niveau 4 blijft het voor alle opleidingssectoren en leerwegen zelfs onder de $3 \%$. Wel zien we wederom dat de MBO-BOL opleidingen het vergeleken met de BBL opleidingen minder goed doen, en bovendien harder lijken te worden getroffen door de crisis. De langdurige intredewerkloosheid onder de gediplomeerden van $\mathrm{MBO}-\mathrm{BBL}$ opleidingen is op alle niveaus marginaal.

Op MBO-niveau 2 zijn het de gediplomeerden van de MBO-BOL landbouw- en techniekopleidingen die sinds 2010 relatief veel vaker langdurig werkzoekend zijn to hun eerste baan. Gediplomeerden van de MBO-BOL opleidingen in de sector Economie kennen structureel een relatief hoge langdurige intredewerkloosheid. 
Figuur 2.3

Veranderingen in het percentage langdurige intredewerkloosheid van MBO-gediplomeerden, tussen 2007 en 2012, naar sector en leerweg
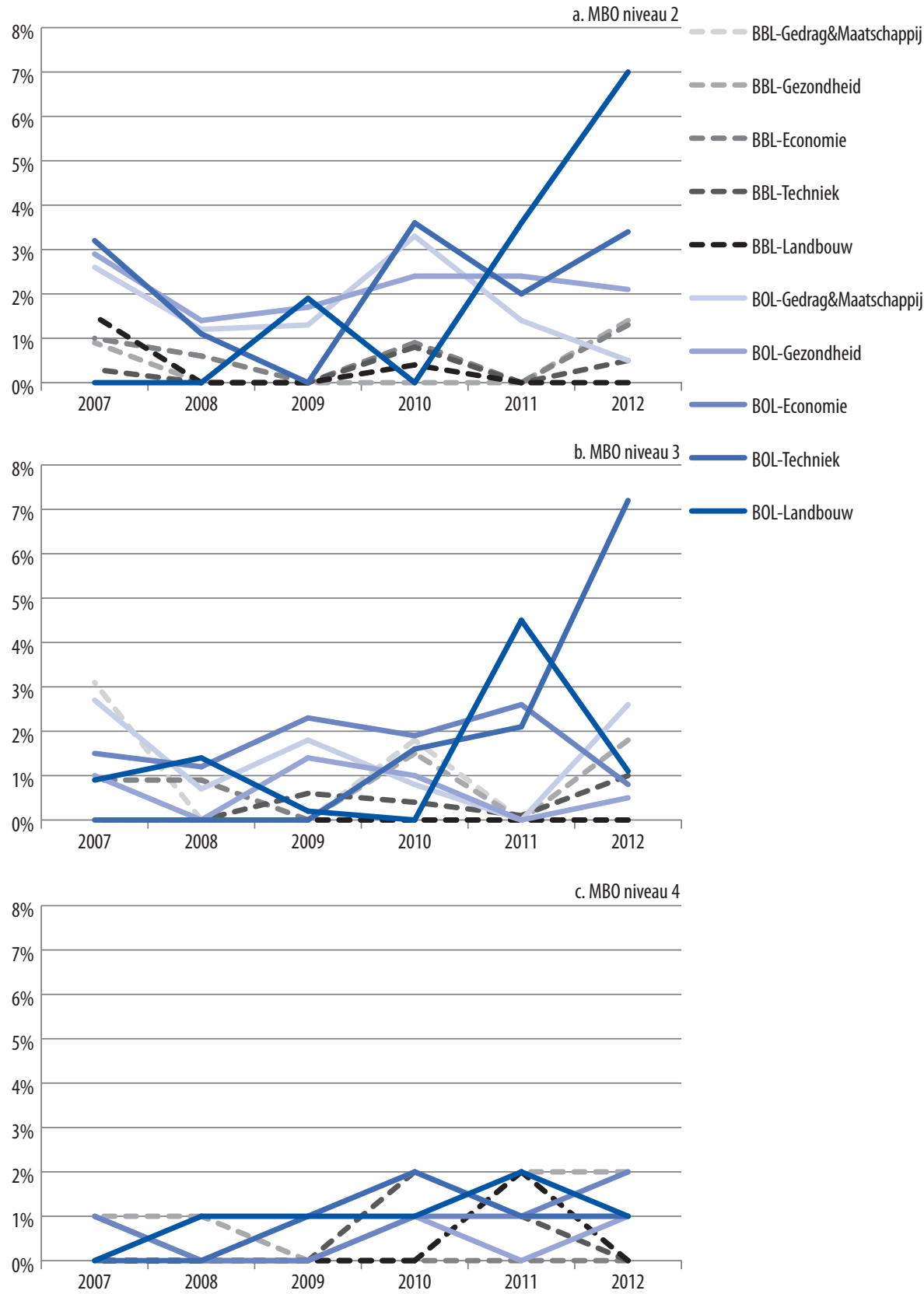

Bron: SIS (ROA), 2007-2012 
Op MBO-niveau 3 zien we dat de MBO-BOL opleidingen in de technische sector relatief hard door de crisis lijken te worden getroffen: in 2012 was ruim $7 \%$ van deze gediplomeerden langdurig werkloos tot de eerste baan.

Hoewel de percentages gediplomeerden van MBO-niveau 4 opleidingen die langdurig werkloos zijn tot hun eerste baan relatief klein is, zien we dat de spreiding van de percentages groter is geworden tijdens de crisis.

Tabel 2.4 presenteert de resultaten van drie multivariate analyses voor de drie MBO-niveaus afzonderlijk. In de tabel zien we bevestigd dat op alle MBO-niveaus langdurige intredewerkloosheid significant vaker voorkomt onder gediplomeerden van MBO-BOL opleidingen, en dat de langdurige intredewerkloosheid in MBO-niveau 4 is toegenomen sinds de crisis. Ook op MBO-niveau 2 is er sprake van een crisiseffect. De gevolgde opleidingsrichting heeft daarentegen geen significant effect op de kans op langdurige intredewerkloosheid, behalve voor de gezondheidszorgopleidingen op MBO-niveau 4: die verkleinen de kans op langdurige intredewerkloosheid.

\section{Tabel 2.4}

Logitanalyse op de kans om >12 maanden na afstuderen geen baan te hebben gevonden, van gediplomeerden op de verschillende MBO-niveaus

\begin{tabular}{|c|c|c|c|}
\hline & MBO2 & MB03 & MBO4 \\
\hline \multicolumn{4}{|l|}{ Opleiding } \\
\hline \multicolumn{4}{|l|}{ BBL (ref.) } \\
\hline $\mathrm{BOL}$ & $1,622 * * *$ & $1,495 * * *$ & $1,734^{* * *}$ \\
\hline \multicolumn{4}{|l|}{ Economie (ref.) } \\
\hline Gedrag en Maatschappij & n.v.t. & 0,087 & 0,081 \\
\hline Landbouw & 0,187 & 0,173 & 0,292 \\
\hline Techniek & 0,133 & 0,160 & $-0,012$ \\
\hline Zorg & $-0,229$ & $-0,441$ & $-0,816^{*}$ \\
\hline \multicolumn{4}{|l|}{ Crisiseffect } \\
\hline Na 2008 (2007-2008 is ref.) & $0,418^{*}$ & 0,331 & $1,363 * * *$ \\
\hline \multicolumn{4}{|l|}{ Persoonlijke achtergrond } \\
\hline Man (vrouwen zijn ref.) & $-0,129$ & 0,314 & $-0,097$ \\
\hline \multicolumn{4}{|l|}{ Autochtonen (ref.) } \\
\hline Niet westerse allochtonen & $0,962 * * *$ & $1,480 * * *$ & $1,049 * * *$ \\
\hline Westerse allochtonen & 0,185 & $1,044^{* *}$ & $1,067^{* * *}$ \\
\hline Leeftijd (gecentreerd) & $0,038 * * *$ & $0,043 * *$ & $0,069 * * *$ \\
\hline \multicolumn{4}{|l|}{ Westen (ref.) } \\
\hline Noorden & $0,634^{*}$ & $0,617^{*}$ & $0,590^{* *}$ \\
\hline Oosten & $-0,055$ & $-0,155$ & $-0,077$ \\
\hline Zuiden & $-0,606$ & $-0,051$ & $-0,335$ \\
\hline Constante & $-6,059 * * *$ & $-6,771 * * *$ & $-7,789^{* * *}$ \\
\hline
\end{tabular}

Noten: ${ }^{*} p<.05{ }^{* *} p<.01{ }^{* * *} p<.001$. Het gecentreerde leeftijdseffect moet worden geïnterpreteerd als effect van een jaar afwijken van de gemiddelde leeftijd

Bron: SIS (ROA), 2007-2012 


\section{Box 2.1}

Nader belicht: de rol van technische studies

Vaak wordt verondersteld dat mensen die een technische opleiding hebben gevolgd het relatief goed doen op de arbeidsmarkt. Uit onze cijfers blijkt dit niet: MBO'ers met een technische opleiding zijn niet minder vaak werkloos dan vergelijkbare gediplomeerden uit een andere sector. Een nadere blik wijst uit dat de werkloosheidskansen voor technisch opgeleid personeel sterk verschillen naar leerweg (zie figuur 2.3). Gediplomeerden uit de sector Techniek uit een BBLopleiding hebben over het algemeen inderdaad een uitstekende uitgangspositie op de arbeidsmarkt. De werkloosheid onder afgestudeerden uit een technische BOL-opleiding is sinds het begin van de crisis zelfs op alle niveaus toegenomen.

In onderstaande figuur is voorts te zien dat afgestudeerden uit alle technische domeinen het door de crisis moeilijker hebben gekregen. De werkloosheid onder afgestudeerden in de Informatie en Communicatietechnologie en technische studies in het domen Media en Vormgeving zijn het hardst door de crisis getroffen.

\section{Figuur 2.4}

Werkloosheidspercentage voor afgestudeerden uit technische domeinen, voor en na 2008

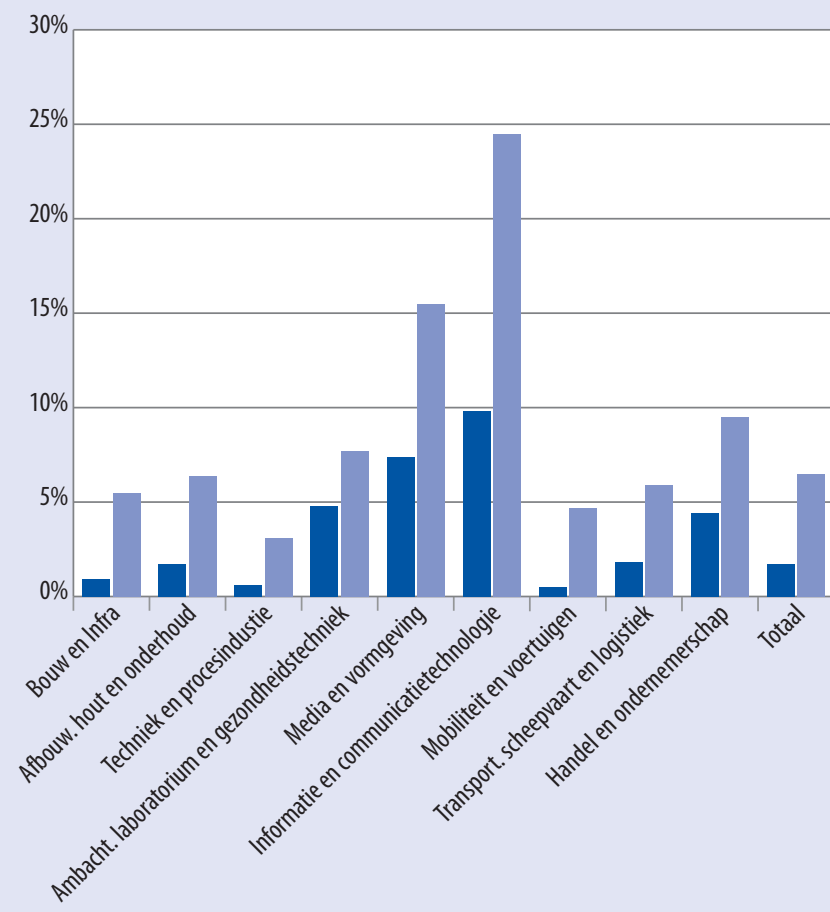

Bron: SIS 2007-2012

Gecontroleerd voor opleidingskenmerken, crisiseffect en persoonlijke achtergrondkenmerken, zien we op alle niveaus dat niet-westerse allochtonen een aanzienlijk grotere kans op langdurige intredewerkloosheid hebben dan autochtonen. Op MBO-niveau 3 en 4 hebben tevens de westerse allochtonen een relatief grote kans op langdurige intredewerkloosheid. 
Het probleem van langdurige intredewerkloosheid speelt met name in het noorden van het land bovengemiddeld sterk. Hoe ouder een gediplomeerde is, hoe groter de kans dat hij/zij na afstuderen langer dan I2 maanden werkzoekend is. Het effect van leeftijd is echter minimaal. Geslacht heeft helemaal geen significant effect op langdurige intredewerkloosheid.

\subsection{Alternatieve strategieën}

Werkloosheid, intredewerkloosheid en NEET vertellen niet het hele verhaal over arbeidsmarktkansen. Wanneer schoolverlaters bij het betreden van de arbeidsmarkt geen baan vinden in het veld waarin ze hebben gestudeerd, kan het zijn dat ze proberen een baan te zoeken in een andere richting. Wanneer ze daarin slagen, is er sprake van een zogeheten horizontale mismatch tussen opleiding en baan. Daarnaast is het mogelijk dat men een baan accepteert onder het gestudeerde niveau. Dit wordt in de onderzoeksliteratuur aangeduid als een zogeheten verticale mismatch. Een ander alternatief is om de transitie naar de arbeidsmarkt uit te stellen en verder te studeren. In deze paragraaf wordt stilgestaan bij de mate waarin $\mathrm{MBO}$-gediplomeerden uit verschillende niveaus, leerwegen en opleidingssectoren zich van dergelijke alternatieve strategieën bedienen.

\subsubsection{Een baan onder het bereikte opleidingsniveau of buiten het gestudeerde veld}

Wanneer mensen werk hebben onder het niveau waarvoor ze zijn opgeleid (verticale mismatch), kan dat leiden tot onbenut potentieel en een grotere doorstroom. Bovendien kan overscholing negatieve externaliteiten hebben voor werknemers lager in de opleidingsstructuur, die de arbeidsmarkt uit kunnen worden gedrukt (Borghans en de Grip, 2000). Wanneer mensen voornamelijk een baan vinden in een ander veld dan dat waarin ze zijn opgeleid (horizontale mismatch), kan dat hun verdere arbeidsmarktkansen negatief beïnvloeden (Wolbers, 2003). Wanneer men een baan binnen de studierichting en op het eigen niveau heeft, spreken we van een baan binnen het kerndomein. In figuur 2.5 is de trend van het aandeel MBO-gediplomeerden weergegeven dat werkzaam is binnen het kerndomein, uitgesplitst naar opleidingsniveau en leerweg.

Uit de figuur blijkt dat het vinden van een baan binnen het kerndomein meer samenhangt met het niveau waarop men is afgestudeerd dan met de leerweg. Bovendien lijkt deze kans nauwelijks te worden beïnvloed door de economische crisis. Anders dan in de eerdere trendfiguren, zien we hier geen duidelijk lagere kansen voor MBO-BOL gediplomeerden ten opzichte van de jongeren met een MBO-BBL diploma. Sterker nog, op $\mathrm{MBO}-$ niveau 3 is de kans dat een gediplomeerde van MBO-BOL binnen het kerndomein aan de slag gaat structureel iets hoger dan voor de MBO-BBL gediplomeerden. 


\section{Figuur 2.5}

Trends in de mate waarin MBO-gediplomeerden werk hebben in het kerndomein (op het bereikte opleidingsniveau en in de gestudeerde richting) tussen 2006 en 2012, naar opleidingsniveau en leerweg

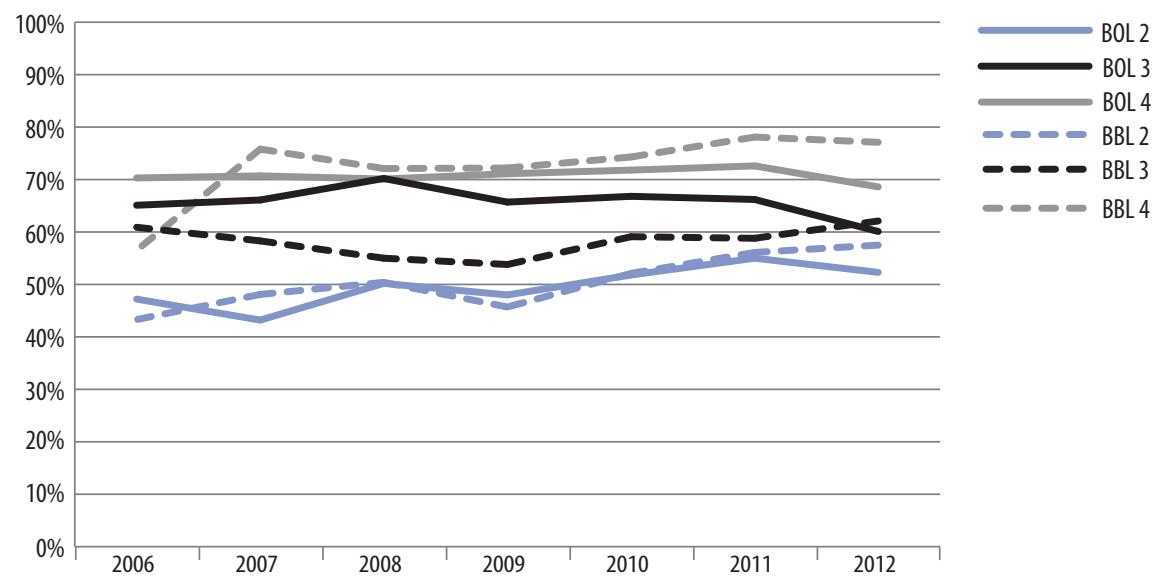

Bron: SIS (ROA), 2006-2012

Uit tabel 2.5 blijkt echter dat deze algemene conclusies nuancering behoeven. Op alle niveaus geldt dat $\mathrm{MBO}-\mathrm{BOL}$ gediplomeerden, vergeleken met vergelijkbare gediplomeerden van het $\mathrm{MBO}-\mathrm{BBL}$, een significant grotere kans hebben op het krijgen van een baan die niet aansluit bij de gevolgde studierichting (een zogeheten horizontale mismatch). Daarentegen hebben gediplomeerden van MBO-BOL niveaus 2 en 3 juist een kleinere kans om onder hun niveau aan de slag te gaan (verticale mismatch).

De kans om een baan te vinden op het juiste niveau is sterk gedifferentieerd naar sector. Gediplomeerden van opleidingen in de zorgsector hebben op vrijwel alle niveaus de grootste kans om een baan op niveau en binnen de eigen studierichting (binnen het kerndomein) te krijgen. Ook gediplomeerden van Gedrag \& Maatschappij-opleidingen hebben een sterk verkleinde kans op een verticale dan wel horizontale mismatch. Met uitzondering van MBO-niveau 3 geldt ook voor de technische opleidingen dat ze zowel de kans op een verticale als een horizontale mismatch verkleinen.

Ten opzichte van de periode voor de crisis, is tijdens de crisis de kans op een horizontale mismatch afgenomen voor gediplomeerden van alle MBO-niveaus. In andere woorden, de $\mathrm{MBO}$-gediplomeerden die zich aanbieden op de arbeidsmarkt, gaan vaker binnen hun eigen studierichting aan de slag. Op MBO-niveau 2 is sinds de crisis tevens de kans op een verticale mismatch verkleind. Wellicht komt dat door de krappe arbeidsmarkt. Waar men voor 2009 nog kon uitwijken naar een baan in een andere dan de gestudeerde richting, is die route door de met de crisis samenhangende krapte op de arbeidsmarkt afgesneden. Een alternatieve verklaring is dat men de transitie van school naar werk in tijden van crisis uit kan stellen en wacht tot men een baan vindt waarvoor men in opgeleid. Een derde mogelijke verklaring is dat werkgevers in tijden van arbeidsmarktkrapte voor de beschikbare banen een grotere keuze hebben uit gekwalificeerde kandidaten met een opleiding in de juiste richting. 
Tabel 2.5

Logitanalyse op de kans dat een baan onder het gestudeerde niveau is, of niet in de sector waarin men gestudeerd heeft, van gediplomeerden op de verschillende MBO-niveaus

\begin{tabular}{|c|c|c|c|}
\hline & $\mathrm{MBO2}$ & MB03 & MB04 \\
\hline \multicolumn{4}{|l|}{ Verticale mismatch } \\
\hline \multicolumn{4}{|l|}{ Opleiding } \\
\hline \multicolumn{4}{|l|}{ BBL (ref.) } \\
\hline BOL & $-0,031$ & $-0,398 * * *$ & $-0,291^{* * *}$ \\
\hline \multicolumn{4}{|l|}{ Economie (ref.) } \\
\hline Gedrag en Maatschappij & n.v.t. & $-1,128^{* * *}$ & $-0,789 * * *$ \\
\hline Landbouw & $-0,177$ & $0,320^{* *}$ & 0,201 \\
\hline Techniek & $-0,277^{* *}$ & $0,446^{* * *}$ & $-0,149^{*}$ \\
\hline Zorg & $-0,888^{* * *}$ & $-0,670^{* * *}$ & $-1,263^{* * *}$ \\
\hline \multicolumn{4}{|l|}{ Crisiseffect } \\
\hline Na 2008 (2007-2008 is ref.) & $-0,135^{*}$ &, 059 & ,111 \\
\hline \multicolumn{4}{|l|}{ Persoonlijke achtergrond } \\
\hline Man (vrouwen zijn ref.) & $-0,155$ &,- 116 & ,086 \\
\hline \multicolumn{4}{|l|}{ Autochtonen (ref.) } \\
\hline Niet westerse allochtonen & $-0,282^{* *}$ &,- 177 &, $251^{*}$ \\
\hline Westerse allochtonen & 0,040 &,- 109 &, $333 * *$ \\
\hline Leeftijd (gecentreerd) & $0,016^{* * *}$ &,- 006 &,$- 018^{* * *}$ \\
\hline \multicolumn{4}{|l|}{ Westen (ref.) } \\
\hline Noorden & $-0,249^{*}$ &,- 039 & 174 \\
\hline Oosten & $-0,076$ &,- 015 &,- 083 \\
\hline Zuiden & $-0,056$ &,- 047 &, 005 \\
\hline Constante & $-0,393 * * *$ &,$- 523^{* * *}$ & $-1,153^{* * *}$ \\
\hline \multicolumn{4}{|l|}{ Horizontale mismatch } \\
\hline \multicolumn{4}{|l|}{ Opleiding } \\
\hline \multicolumn{4}{|l|}{ BBL (ref.) } \\
\hline $\mathrm{BOL}$ & $0,412 * * *$ & $0,298^{* * *}$ & 0,283 *** \\
\hline \multicolumn{4}{|l|}{ Economie (ref.) } \\
\hline Gedrag en Maatschappij & n.v.t. & $-1,140^{* * *}$ & $-1,022^{* * *}$ \\
\hline Landbouw & 0,027 & $-0,055$ & $-0,138$ \\
\hline Techniek & $-0,346 * * *$ & $-0,406^{* * *}$ & $-0,571^{* * *}$ \\
\hline Zorg & $-1,029 * * *$ & $-1,204^{* * *}$ & $-1,465^{* * *}$ \\
\hline \multicolumn{4}{|l|}{ Crisiseffect } \\
\hline Na 2008 (2007-2008 is ref.) & $-0,378^{* * *}$ & $-0,225^{* * *}$ & $-0,099^{*}$ \\
\hline \multicolumn{4}{|l|}{ Persoonlijke achtergrond } \\
\hline Man (vrouwen zijn ref.) & $-0,297^{* * *}$ & $-0,214^{*}$ & $-0,136^{*}$ \\
\hline \multicolumn{4}{|l|}{ Autochtonen (ref.) } \\
\hline Niet westerse allochtonen & $0,217^{*}$ & $0,304^{* *}$ & $0,253^{* *}$ \\
\hline Westerse allochtonen & 0,043 & 0,113 & 0,223 \\
\hline Leeftijd (gecentreerd) & $0,016^{* * *}$ & $-0,007$ & $-0,015^{* *}$ \\
\hline \multicolumn{4}{|l|}{ Westen (ref.) } \\
\hline Noorden & 0,082 & $-0,017$ & 0,060 \\
\hline Oosten & 0,008 & $-0,086$ & $-0,075$ \\
\hline Zuiden & $-0,091$ & 0,002 & 0,002 \\
\hline Constante & $-0,150$ & $-0,614^{* * *}$ & $-0,746^{* * *}$ \\
\hline
\end{tabular}

Noten: ${ }^{*} p<.05{ }^{* *} p<.01{ }^{* * *} p<.001$. Het gecentreerde leeftijdseffect moet worden geïnterpreteerd als effect van een jaar afwijken van de gemiddelde leeftijd

Bron: SIS (ROA), 2007-2012 
Mannen hebben een kleinere kans op een horizontale mismatch dan vrouwen, maar hun kans op een verticale mismatch is niet significant verschillend van de vrouwelijke gediplomeerden. Een effect van leeftijd op de kans op een verticale dan wel horizontale mismatch is enkel significant op niveaus 2 en 4 . Voor de gediplomeerden van MBO-niveau 2 geldt dat hoe ouder de gediplomeerde is, hoe groter de kans op zowel een verticale als een horizontale mismatch. Het tegenovergestelde is het geval voor de gediplomeerden van MBO-niveau 4.

Niet-westerse allochtonen hebben op alle niveaus een grotere kans op een horizontale mismatch dan vergelijkbare autochtone gediplomeerden. Op MBO-niveau 4 hebben ze tevens een grotere kans op een verticale mismatch. Gediplomeerde niet-westerse allochtonen van MBO-niveau 2 opleidingen hebben daarentegen juist een kleinere kans op een verticale mismatch dan vergelijkbare gediplomeerden van hetzelfde opleidingsniveau. Er is geen duidelijke relatie tussen de regio waar de gediplomeerde woonachtig is en de kans op een verticale dan wel horizontale mismatch.

\subsubsection{Doorstuderen}

Een andere alternatieve strategie om werkloosheid te vermijden is om de transitie naar de arbeidsmarkt uit te stellen en door te studeren. Uit tabel 2.6 is af te lezen dat gediplomeerden van $\mathrm{MBO}-\mathrm{BOL}$ opleidingen op alle niveaus er significant vaker voor kiezen door te studeren dan vergelijkbare MBO-BBL gediplomeerden. Merk op dat uit tabellen 2.I en 2.4 bleek dat de (langdurige) werkloosheid onder MBO-BOL gediplomeerden tevens aanzienlijk hoger was dan onder gediplomeerden van MBO-BBL. Dat betekent dat doordat MBO-BOL'ers significant vaker doorleren, zij zich relatief minder vaak aanbieden op de arbeidsmarkt, en dat de MBO-BOL'ers díe zich op de arbeidsmarkt aanbieden, een aanzienlijk kleinere kans op werk hebben dan vergelijkbare MBO-BBL'ers.

De kans op doorstuderen is voor de gediplomeerden van MBO-niveaus 2 en 3 sinds de crisis duidelijk vergroot. Voor gediplomeerden van MBO-niveau 4 is dit echter niet het geval. Wellicht impliceert dat dat deze jongeren niet vaker dan vóór de crisis doorstromen naar HBO-opleidingen.

De kans om door te studeren is sterk gedifferentieerd naar sector. Op alle MBO-niveaus studeren gediplomeerden van landbouwopleidingen minder vaak door na het behalen van hun diploma. Op niveaus 3 en 4 hebben jongeren die een opleiding in de zorgsector hebben afgerond een relatief kleine kans op doorstuderen. Daarentegen hebben de gediplomeerden van gezondheidszorgopleidingen op niveau 2 juist en relatief grote kans op doorleren. Hoewel een diploma van een economische opleiding op MBO-niveau 2 de kans op doorstuderen aanzienlijk verkleint, hebben gediplomeerden van economische opleidingen op de hogere MBO-niveaus juist een relatief grote kans te kiezen voor doorstuderen. 
Op alle niveaus hebben niet-westerse allochtonen een grotere kans om voor doorstuderen te kiezen dan vergelijkbare autochtone gediplomeerden. Daarnaast geldt op alle niveaus dat de oudere gediplomeerden een iets kleinere kans op doorstuderen hebben dan hun wat jongere studiegenoten. Op MBO-niveaus 3 en 4 kiezen mannen er significant vaker dan vrouwen voor om door te studeren. Tot slot zien we dat gediplomeerden van MBO-niveau 2 die in het oosten van het land wonen het vaakst kiezen voor doorleren, terwijl dat onder de MBO-niveau 4 gediplomeerden voor degenen die in het noorden woonachtig zijn geldt.

\section{Tabel 2.6}

Logitanalyse op de kans om door te studeren, van gediplomeerden op de verschillende MBO-niveaus.

\begin{tabular}{|c|c|c|c|}
\hline & MBO2 & MB03 & MB04 \\
\hline \multicolumn{4}{|l|}{ Opleiding } \\
\hline \multicolumn{4}{|l|}{ BBL (ref.) } \\
\hline $\mathrm{BOL}$ & $0,625 * * *$ & $0,693 * * *$ & 0,867 *** \\
\hline \multicolumn{4}{|l|}{ Economie (ref.) } \\
\hline Gedrag en Maatschappij & n.v.t. & $-0,293 * * *$ & $0,233^{* * *}$ \\
\hline Landbouw & 0,098 & $-0,562 * * *$ & $-0,412^{* * *}$ \\
\hline Techniek & $0,471^{* * *}$ & $-0,084$ & $-0,153^{* * *}$ \\
\hline Zorg & $0,482^{* * *}$ & $-0,369 * * *$ & $-0,460 * * *$ \\
\hline \multicolumn{4}{|l|}{ Crisiseffect } \\
\hline Na 2008 (2007-2008 is ref.) & $0,170^{* * *}$ & $0,211 * * *$ & 0,018 \\
\hline \multicolumn{4}{|l|}{ Persoonlijke achtergrond } \\
\hline Man (vrouwen zijn ref.) & $-0,108$ & $0,330 * * *$ & $0,330^{* * *}$ \\
\hline \multicolumn{4}{|l|}{ Autochtonen (ref.) } \\
\hline Niet westerse allochtonen & $0,182^{* *}$ & $0,295 * * *$ & $0,449 * * *$ \\
\hline Westerse allochtonen & $-0,039$ & $-0,015$ & 0,074 \\
\hline Leeftijd (gecentreerd) & $-0,071^{* * *}$ & $-0,058^{* * *}$ & $-0,142^{* * *}$ \\
\hline \multicolumn{4}{|l|}{ Westen (ref.) } \\
\hline Noorden & 0,084 & $-0,077$ & $0,227 * * *$ \\
\hline Oosten & $0,142 *$ & 0,016 & $0,094^{*}$ \\
\hline Zuiden & 0,086 & 0,043 & $0,182^{* * *}$ \\
\hline Constante & $-0,945^{* * *}$ & $-1,176^{* * *}$ & $-0,798 * * *$ \\
\hline
\end{tabular}

Noten: ${ }^{*} p<.05{ }^{* *} p<.01{ }^{* * *} p<.001$. Het gecentreerde leeftijdseffect moet worden geïnterpreteerd als effect van een jaar afwijken van de gemiddelde leeftijd

Bron: SIS (ROA), 2007-2012

\subsection{Verklaringen voor werkloosheid onder MBO'ers na 2008}

In paragraaf 2.2 hebben we laten zien dat de werkloosheid onder MBO-gediplomeerden sterk gedifferentieerd is naar leerweg, opleidingssector en -niveau. Schoolverlaters uit de BOL hebben een grotere kans om werkloos te zijn. Schoolverlaters uit de Sector Gezondheidszorg hebben betere kansen op de arbeidsmarkt dan gediplomeerden uit andere sectoren. Ook is de kans op werkloosheid kleiner onder de gediplomeerden van de hogere niveaus. 
Box 2.2

Lonen schoolprestaties?

In tabel 2.7 worden de verbanden tussen schoolprestaties in het MBO en de arbeidsmarktprestaties van MBO -schoolverlaters nader onderzocht. Een bovengemiddeld hoog eindexamencijfer verkleint de werkloosheidskansen niet. Het vergroot wel de kans dat men werk vindt op het juiste niveau. Mensen die ondergemiddeld presteren, hebben een hogere kans op werkloosheid, alsook een hogere kans om buiten hun studierichting en onder hun niveau te werken. Excellente schoolprestaties lonen dus maar ten dele, terwijl slecht presteren wordt afgestraft.

Tabel 2.7

De arbeidsmarktkansen van excellente presteerders en ondergemiddelde presteerders

\begin{tabular}{l|c|c|c|c}
\hline & Werkloos & $\begin{array}{c}\text { Intredewerkloosheid } \\
>12 \mathrm{mnd}\end{array}$ & Overeducatie & $\begin{array}{c}\text { Horizontale } \\
\text { mismatch }\end{array}$ \\
\hline Gemiddeld eindcijfer & & & & \\
\hline Bovengemiddeld eindcijfer & $-0,088$ & 0,067 & $-0,092^{*}$ & 0,017 \\
\hline Ondergemiddeld eindcijfer & $0,297^{* *}$ & 0,206 & $0,290^{* *}$ & $0,219^{* * *}$ \\
\hline
\end{tabular}

Noten: ${ }^{*} p<.05{ }^{* *} p<.01{ }^{* * *} p<.001$. Logitanalyse op de kans om werkloos te zijn, langer dan 12 maanden intredewerkloos te zijn, te hoog geschoold te zijn voor de baan, een baan vinden buiten de eigen studierichting, en verder te leren, van gediplomeerden op de verschillende MB0-niveaus. De effecten zijn gecontroleerd voor individuele achtergrondkenmerken, voor opleidingsrichtingen en afstudeerniveau. Volledige modellen in Bijlage 1.

Bron: SIS (ROA), 2009- 2012

Hoe kan werkloosheid onder $\mathrm{MBO}$-gediplomeerden worden verklaard? Welke factoren spelen verder een rol, naast de al genoemde opleidingskenmerken? In tabel 2.8 onderzoeken we in een viertal regressiemodellen een aantal verschillende verklaringen. Daarbij moet worden opgemerkt dat we in deze analyse geen volledig beeld beogen te schetsen van alle mogelijke verklaringen van werkloosheid in het $\mathrm{MBO}$, en ook niet trachten vast te stellen wat het relatieve belang van de geboden verklaringen is. Deze analyse beoogt slechts inzichtelijk te maken of en in hoeverre een aantal veelgehoorde theoretische verklaringen van werkloosheid een aantoonbare bijdrage kunnen leveren aan de verklaring van de arbeidsmarktprestaties van de $\mathrm{MBO}$-cohorten die sinds 2008 op de arbeidsmarkt zijn ingestroomd. Daarbij ligt de nadruk op persoonlijke achtergrondkenmerken, zoals schoolprestaties en sociaaleconomische herkomst, alsook op enkele algemene kenmerken van opleidingen.

Er wordt sinds een aantal jaren sterk ingezet op het bevorderen van excellentie in het onderwijs (zie bijvoorbeeld de rapportage over dit onderwerp die Mooij en Fettelaar (20I0) schreven voor de Onderwijsraad). Maar leiden excellente prestaties ook tot betere kansen op de arbeidsmarkt? Uiteraard is een aantal niet aan schoolcijfers te relateren eigenschappen van een werknemer van belang bij het evalueren van diens prestaties, zoals houding, gedrag, aanstuurbaarheid, en ontwikkelingskansen. Maar vooral tijdens het aannameproces vormen cijfers voor werkgevers een signaal over iemands cognitieve capaciteiten, maar ook over niet te observeren eigenschappen als werklust en doorzettingsvermogen. Er is dus aanleiding om een verband tussen cijfers en kansen op werk te veronderstellen. In het eerste model van tabel 2.8 bezien we of, in vergelijking met gemiddelde $\mathrm{MBO}$-gediplomeerden, bovengemiddeld presterende jongeren een betere kans op 
werk hebben, en benedengemiddelde studenten een slechtere. Alleen dat laatste blijkt zo te zijn. Onze gegevens laten zien dat schoolverlaters die het $\mathrm{MBO}$ afsloten met een 8 of hoger, niet minder vaak werkloos zijn. De effecten van bovengemiddeld presteren zijn weliswaar negatief, maar niet statistisch significant. Deze resultaten moeten dan ook met terughoudendheid worden geïnterpreteerd. Wij concluderen dat de analyses geen aanleiding bieden te veronderstellen dat excellente prestaties in het $\mathrm{MBO}$ de kansen op werk vergroten. Wel laten onze analyses zien, dat excellente schoolverlaters die een baan vinden, minder vaak een baan onder hun niveau hebben (zie box 2.2). In die zin betalen excellente resultaten zich dus terug.

De resultaten suggereren wel dat het behalen van een eindexamencijfer onder het gemiddelde samenhangt met een hogere kans op werkloosheid. Aanvullende analyses laten zien dat schoolverlaters met een relatief laag eindcijfer verder een grotere kans hebben om een baan te vinden onder hun niveau, en een grotere kans een baan te hebben in een veld waarvoor ze niet hebben gestudeerd (zie box 2.2). Als we deze resultaten in het licht van de signaaltheorie (Spence, I973) interpreteren, dan kan het zo zijn dat werkgevers relatief lage schoolprestatie opvatten als een signaal van incompetentie.

Een tweede belangrijke verklaring voor prestaties in het onderwijs en op de arbeidsmarkt is gelegen in de invloed van ouderlijke achtergronden. Model 2 in tabel 2.8 laat zien dat MBO-schoolverlaters uit een tweeoudergezin een hogere kans op werk hebben dan mensen uit andere gezinsvormen. Daarnaast blijkt uit veel onderzoek dat mensen uit de lagere sociaaleconomische strata het relatief moeilijk hebben op de arbeidsmarkt (Breen en Johnson, 2005). Een mogelijke verklaring is gelegen in de verschillende maten van sociaal kapitaal die leden van verschillende sociaaleconomische groepen kunnen aanwenden om hun onderwijsprestaties om te zetten in een beloning op de arbeidsmarkt (naar: Lin, 1999). Zo kan worden verondersteld dat hoger opgeleide ouders grotere en voor arbeidsmarktintegratie meer bruikbare sociale netwerken hebben, waarvan hun kinderen kunnen profiteren wanneer ze op zoek gaan naar een hogere baan.

In model 2 zien we, dat deze interpretatie in het geval van MBO'ers na 2008 nuancering behoeft. In vergelijking met schoolverlaters waarvan de vader een middelbare opleiding hebben genoten, zijn de werkloosheidskansen van zowel schoolverlaters met lager opgeleide vaders, als die met hoogopgeleide vaders, hoger. Deze bevinding lijkt in strijd met interpretaties die leunen op aannames over de hierboven aangehaalde arbeidsmarktprestaties-bevorderende persoonlijke eigenschappen van hoger opgeleiden. Vanuit de sociaalkapitaaltheorie geïnterpreteerd, zouden onze bevindingen betekenen dat de sociale netwerken van middelbaar opgeleide vaders meer geschikt zijn voor het vinden van een baan op MBO-niveau dan de netwerken van lager en hoger opgeleide vaders. 
Tabel 2.8

Logitanalyse op de kans om werkloos te zijn, van gediplomeerden uit het MBO

\begin{tabular}{|c|c|c|c|c|}
\hline & Model 1 & Model 2 & Model 3 & Model 4 \\
\hline \multicolumn{5}{|l|}{ Opleiding } \\
\hline \multicolumn{5}{|l|}{ BBL (ref.) } \\
\hline $\mathrm{BOL}$ & $0,838^{* * *}$ & $0,842^{* * *}$ & $0,839 * * *$ & $0,829 * * *$ \\
\hline \multicolumn{5}{|l|}{ MBO2 (ref.) } \\
\hline MBO3 & $-0,419^{* * *}$ & $-0,415^{* * *}$ & $-0,420 * * *$ & $-0,423$ *** \\
\hline MB04 & $-0,808^{* * *}$ & $-0,805^{* * *}$ & $-0,805^{* * *}$ & $-0,809 * * *$ \\
\hline \multicolumn{5}{|l|}{ Economie (ref.) } \\
\hline Gedrag en Maatschappij & $-0,159$ & $-0,154$ & $-0,152$ & $-0,157$ \\
\hline Landbouw & 0,053 & 0,063 & 0,054 & 0,036 \\
\hline Techniek & $-0,054$ & $-0,043$ & $-0,047$ & $-0,057$ \\
\hline Zorg & $-0,745^{* * *}$ & $-0,738^{* * *}$ & $-0,736^{* * *}$ & $-0,732^{* * *}$ \\
\hline \multicolumn{5}{|l|}{ Persoonlijke achtergrond } \\
\hline Man (vrouwen zijn ref.) & $-0,346^{* * *}$ & $-0,344 * * *$ & $-0,351 * * *$ & $-0,347$ *** \\
\hline \multicolumn{5}{|l|}{ Autochtonen (ref.) } \\
\hline Niet westerse allochtonen & $0,806^{* * *}$ & $0,781^{* * *}$ & $0,781^{* * *}$ & $0,777^{* * *}$ \\
\hline Westerse allochtonen & $0,593 * * *$ & $0,582 * * *$ & $0,583 * * *$ & $0,578^{* * *}$ \\
\hline Leeftijd (gecentreerd) & $0,021^{* * *}$ & $0,020 * * *$ & $0,020 * * *$ & $0,020^{* * *}$ \\
\hline \multicolumn{5}{|l|}{ Westen (ref.) } \\
\hline Noorden & $0,615^{* * *}$ & $0,622 * * *$ & $0,615 * * *$ & $0,613 * * *$ \\
\hline Oosten & 0,060 & 0,061 & 0,056 & 0,050 \\
\hline Zuiden & 0,044 & 0,035 & 0,031 & 0,035 \\
\hline \multicolumn{5}{|l|}{ Gemiddeld eindcijfer (ref.) } \\
\hline Bovengemiddeld eindcijfer & $-0,091$ & $-0,088$ & $-0,092$ & $-0,095$ \\
\hline Ondergemiddeld eindcijfer & $0,288^{* *}$ & $0,297^{* *}$ & $0,287^{* *}$ & $0,282 * *$ \\
\hline \multicolumn{5}{|l|}{ Geen twee-oudergezin (ref.) } \\
\hline Twee-oudergezin (eenoudergezin=ref.) & & $-0,176^{*}$ & $-0,181 *$ & $-0,185^{*}$ \\
\hline \multicolumn{5}{|l|}{ Vader middelbaar opgeleid (ref.) } \\
\hline Vader laag opgeleid & & $0,316 * * *$ & $0,316^{* * *}$ & $0,315^{* * *}$ \\
\hline Vader hoog opgeleid & & $0,386^{* * *}$ & $0,386^{* * *}$ & $0,378 * * *$ \\
\hline Opleiding te theoriegericht (niet=ref.) & & & $0,240^{*}$ & 0,131 \\
\hline Opleiding te praktijkgericht (niet=ref.) & & & 0,040 & 0,018 \\
\hline Opleiding te smal (niet=ref.) & & & & $0,507^{* * *}$ \\
\hline Opleiding te breed (niet=ref.) & & & & 0,003 \\
\hline Constante & $-3,403 * * *$ & $-3,471^{* * *}$ & $-3,488 * * *$ & $-3,497^{* * *}$ \\
\hline
\end{tabular}

Noten: ${ }^{*} p<.05{ }^{* *} p<.01{ }^{* * *} p<.001$. Het gecentreerde leeftijdseffect moet worden geïnterpreteerd als effect van een jaar afwijken van de gemiddelde leeftijd

Bron: SIS (ROA), 2007-2012

Ook laat de internationale onderzoeksliteratuur zien dat immigrantenkinderen het vaak minder goed doen op de arbeidsmarkt (zie bijvoorbeeld: Van Tubergen, 2006). In box 2.3 valt te zien dat $\mathrm{MBO}$-schoolverlaters met een immigratieachtergrond een grotere kans hebben op werkloosheid, alsook op een langere intredewerkloosheid, ongeacht of ze een westerse of niet-westerse achtergrond hebben. Maar met name niet-westerse immigran- 
tenkinderen zijn minder vaak te vinden in banen onder hun opleidingsniveau of buiten hun studierichting. Dit suggereert wellicht dat de hogere werkloosheidskansen voor deze groep (deels) verklaard zouden kunnen worden door strategisch gedrag van de schoolverlaters zelf, in de zin dat immigrantenkinderen wellicht minder snel genoegen nemen met een baan onder hun niveau of buiten hun studierichting.

\section{Box 2.3}

Hoe doen immigrantenkinderen het?

De analyses in tabel 2.9 laten zien dat schoolverlaters met een immigrantenachtergrond vaker werkloos zijn en een grotere kans op een langdurige transitie naar de arbeidsmarkt hebben. Maar wanneer niet-westerse immigranten een baan vinden, is de kans groter dat ze een baan vinden op het juiste niveau en in de juiste richting. Daarenboven studeren nietwesterse immigrantenkinderen vaker door dan autochtone schoolverlaters. Dit geldt niet voor immigrantenkinderen met een westerse achtergrond.

Tabel 2.9

De arbeidsmarktkansen van immigrantenkinderen uit het $\mathrm{MBO}$

\begin{tabular}{l|c|c|c|c|c}
\hline & Werkloos & $\begin{array}{c}\text { Intrede- } \\
\text { werkloosheid } \\
>12 \mathrm{mnd}\end{array}$ & Overeducatie & $\begin{array}{c}\text { Horizontale } \\
\text { mismatch }\end{array}$ & Verder leren \\
\hline Niet-westerse allochtonen & $0,781^{* * *}$ & $1,031^{* * *}$ & $-0,262^{* * *}$ & $-0,149^{* *}$ & $0,364^{* * *}$ \\
\hline Westerse allochtonen & $0,582^{* * *}$ & $0,838^{* * *}$ & $-0,101$ & $-0,110$ & 0,008 \\
\hline
\end{tabular}

Noten: ${ }^{*} p<.05{ }^{* *} p<.01{ }^{* * *} p<.001$. Logitanalyse op de kans om werkloos te zijn, langer dan 12 maanden intredewerkloos te zijn, te hoog geschoold te zijn voor de baan, een baan vinden buiten de eigen studierichting, en verder te leren, van gediplomeerden op de verschillende MBO-niveaus. Autochtonen zijn referentie. De effecten zijn gecontroleerd voor individuele achtergrondkenmerken, alsook voor opleidingsrichtingen en afstudeerniveau. Volledige modellen in Bijlage 1.

Bron: SIS (ROA),2009-2012

Modellen 3 en 4 geven enig inzicht in de mate waarin de inhoud van opleidingen een effect hebben op de werkloosheidskansen van schoolverlaters. Hierbij gebruiken we de door de schoolverlaters zelf geformuleerde oordelen over hun opleiding als meting voor de inhoud van die opleidingen. Merk op dat de schoolverlaters dit oordeel post hoc hebben gegeven, en met medeneming van hun oordeel over de mate waarin de door hen gevolgde opleiding nuttig is op de arbeidsmarkt.

In model 3 wordt bezien of en in hoeverre de mate waarin opleidingen te sterk theoriegericht of te sterk praktijkgericht zijn, een invloed hebben op de werkloosheidskansen. Het blijkt dat gediplomeerden van opleidingen waarvan schoolverlaters vinden dat het curriculum te theoriegericht was, een hogere werkloosheid kennen. Daarentegen lijkt de mate waarin schoolverlaters vinden dat hun opleiding te praktijkgericht was, geen effect te hebben op de werkloosheidskansen. We concluderen dat een te grote mate van theoriegerichtheid van $\mathrm{MBO}$-opleidingen de kansen op werk niet bevorderen.

In model 4 wordt gekeken naar de mate waarin schoolverlaters vinden dat het curriculum van de door hen gevolgde opleiding te smal of te breed was. Dit kan worden gezien als 
een indicatie van de mate waarin jongeren specifieke dan wel generieke vaardigheden hebben opgedaan. Het blijkt dat schoolverlaters van opleidingen die te specifiek worden ervaren, gedurende de crisis een grotere kans op werkloosheid hebben. Dit is een opvallende bevinding. In de internationale onderzoeksliteratuur wordt de mate van specificiteit van het beroepsgerichte onderwijs vaak gezien als bevorderend voor de werkgelegenheid onder jongeren (Breen, 2005). Onze bevindingen laten echter zien dat het aanleren van te specifieke vaardigheden de arbeidsmarktkansen verkleint. Een mogelijke interpretatie van deze bevindingen ligt besloten in de overweging dat mensen met te veel specifieke beroepsgerichte vaardigheden minder gemakkelijk in een beroep kunnen instromen waarvoor zij niet zijn opgeleid. In tijden van krapte op de arbeidsmarkt maakt dit hun mogelijkerwijs minder flexibel dan mensen met meer generieke vaardigheden. De bevindingen in box 2.4 lijken deze interpretatie echter deels te logenstraffen. Jongeren die de door hen gevolgde opleiding als te smal kenschetsen, zijn immers vaker werkzaam in functies buiten hun eigen vakgebied dan mensen die de gevolgde opleiding niet als te smal kernmerken. Ze zijn echter ook in sterkere mate werkzaam in functies onder hun niveau.

Merk overigens op dat het negatieve verband tussen het hebben gevolgd van een BOL-opleiding en de kansen op werk ook gecontroleerd voor individuele kenmerken en deze opleidingskenmerken overeind blijft.

\section{Box 2.4}

Wat is de rol van specificiteit?

In tabel 2.10 zien we dat schoolverlaters van opleidingen die te specifieke vaardigheden aanleren, vaker werkloos zijn, en vaker te vinden zijn in banen buiten hun eigen veld en onder hun eigen niveau.

Tabel 2.10

De rol van geleerde vaardigheden in het MBO

\begin{tabular}{l|c|c|c}
\hline & Werkloos & Overeducatie & Horizontale mismatch \\
\hline Opleiding te smal & $0,507^{* * *}$ & $0,274^{* * *}$ & $0,382^{* * *}$ \\
\hline
\end{tabular}

Noten: ${ }^{*} p<.05^{* *} p<.01{ }^{* * *} p<.001$. Logitanalyse op de kans om werkloos te zijn, langer dan 12 maanden intredewerkloos te zijn, te hoog geschoold te zijn voor de baan, een baan vinden buiten de eigen studierichting, en verder te leren, van gediplomeerden op de verschillende MBO-niveaus. Schoolverlaters met middelbaar opgeleide vaders zijn referentie. De effecten zijn gecontroleerd voor individuele achtergrondkenmerken, alsook voor opleidingsrichtingen en afstudeerniveau. Volledige modellen in Bijlage 1.

Bron: SIS (ROA), 2009- 2012

\subsection{Conclusies}

De in dit hoofdstuk gepresenteerde analyses laten zien dat de arbeidsmarktpositie van MBO'ers sinds 2009 sterk is verslechterd. In vergelijking met de periode voorafgaand aan de economische crisis, zijn MBO'ers sinds 2009 vaker werkloos, hebben een langere intredewerkloosheid, hebben een grotere kans als om in een NEET positie buiten de arbeids- 
markt terecht te komen, en passen vaker alternatieve strategieën toe, zoals het aannemen van een baan buiten de eigen studierichting, of een baan onder niveau.

Maar niet alle MBO-schoolverlaters zijn gelijk. Over het algemeen geldt dat de arbeidsmarktkansen van $\mathrm{MBO}$-schoolverlaters beter zijn naarmate hun opleidingsniveau hoger is. Dit is in lijn met eerdere bevindingen (Meng et al., 2009). Daarnaast is er een sterke differentiatie naar leerweg. Schoolverlaters van opleidingen uit de BOL hebben structureel slechtere arbeidsmarktkansen dan gediplomeerden van een BBL-opleding. In vergelijking met vergelijkbare gediplomeerden uit een BBL-opleiding zijn de BOL'ers vaker werkloos, hebben een grotere kans op een langer dan een jaar intredewerkloosheid, nemen vaker een baan onder hun niveau aan, nemen vaker een baan buiten hun studierichting aan, en stellen vaker hun arbeidsmarkttransitie uit. Bovendien hebben ze een grotere kans om al aan het begin van hun loopbaan als NEET buiten de arbeidsmarkt terecht te komen. Tezelfdertijd moet worden opgemerkt dat de arbeidsmarktkansen van schoolverlaters met een opleiding uit de BBL over het algemeen uitstekend zijn, en relatief onaangetast zijn door de economische crisis.

Deze algemene conclusies gelden voor alle MBO-niveaus, en gelden voor bijna alle opleidingssectoren. De door ons gevonden verschillen in arbeidsmarktkansen tussen gediplomeerden uit de opleidingen uit de BOL en BBL zijn aanzienlijk, structureel, en robuust. Verschillen kunnen slechts zeer beperkt worden verklaard door kenmerken van individuen en opleidingsrichtingen. Dat roept vragen op over de mate waarin de BOL-opleidingen MBO'ers goed voorbereiden op de huidige arbeidsmarkt. Ten dele ligt de verklaring waarschijnlijk in het feit dat BBL-opgeleiden na afronding van hun opleiding in feite al werkzaam zijn, waarmee de overgang van school naar werk veel minder groot is. Ten tweede wordt vaak gewezen op de sterkere mate van beroepsspecificiteit van in het BBL aangeleerde vaardigheden. Een derde verklaring voor de geobserveerde verschillen tussen BOL en BBL ligt besloten in de grotere selectiviteit van BBL-opleidingen, waarvan de instroom afhankelijk is van de beschikbaarheid van leerwerkplekken. Deze beschikbaarheid is tijdens de crisis verder afgenomen, waarmee de instroom van leerlingen in BBL-opleidingen nog selectiever is geworden dan voor de crisis.

Het arbeidsmarktsucces van gediplomeerde MBO'ers kan verder worden gedifferentieerd naar de sector waarbinnen de opleiding is gevolgd. Afgestudeerden in de sector Gezondheidszorg doen het over het algemeen goed. Wellicht verrassend lijkt dat niet te gelden voor alle afgestudeerden uit de sector Techniek. Waar technisch geschoolden het over het algemeen goed doen, geven de analyses aanleiding voor de veronderstelling dat de arbeidsmarktkansen van afgestudeerden uit de sector Techniek op de lagere BOL-niveaus sterk verslechterd zijn.

De in dit hoofdstuk gepresenteerde beschrijvende analyses laten zien dat de generalisatie naar sectoren, leerwegen en niveaus verdere nuancering behoeft. Gegevens uit de ROA Schoolverlatersonderzoeken laten zien dat er een sterke differentiatie in de werkloosheidskansen bestaat tussen opleidingen. Verschillende opleidingen worden verschil- 
lend getroffen door de crisis. Uit onze cijfers blijkt bijvoorbeeld dat schoolverlaters in de secretariële sector, alsook in de sector Houtbewerking en Wegvervoer het moeilijk hebben op de arbeidsmarkt. Ook moet worden opgemerkt dat onder de ons geobserveerde opleidingen met de hoogste werkloosheid, ook opleidingen uit de BBL zitten. Dit geldt voor alle niveaus.

Onze analyses geven enkele suggesties voor de mate waarin $\mathrm{MBO}$-opleidingen de arbeidsmarktpositie van hun deelnemers wellicht kunnen verbeteren. Gediplomeerden van opleidingen die met terugwerkende kracht als te specifiek werden betiteld, zijn vaker werkloos. Een te specifiek beroepsgerichte opleiding lijkt in tijden van economische crisis te leiden tot kwetsbaarheid op de arbeidsmarkt. We veronderstellen dat dit vooral geldt voor opleidingsrichtingen in arbeidsmarktsectoren die door de crisis met een krappe arbeidsmarkt te maken hebben. Wanneer opleidingen opleiden voor banen die er niet zijn, moeten gediplomeerden andersoortige banen accepteren. Wellicht dat gediplomeerden van opleidingen met een te specifiek profiel door de specificiteit van hun vaardigheden gehinderd worden in hun zoektocht naar werk buiten de gevolgde opleidingsrichting. Hoewel jongeren die hun opleiding als te smal hebben ervaren, een grotere kans hebben om werk buiten hun sector te accepteren, doen ze dat vaker onder het door hen gestudeerde niveau. We concluderen tentatief dat MBO-opleidingen er in ieder geval goed aan doen ervoor te zorgen dat hun opleidingen naast beroepsspecifieke vaardigheden, ook inzetten op het bijbrengen van generieke vaardigheden om daarmee de flexibiliteit van hun gediplomeerden te vergroten.

Excellentie van opleidingen en deelnemers in het MBO staat sterk in de belangstelling, zowel van wetenschappers als van beleidsmakers. Onze analyses laten zien dat MBO-gediplomeerden hun eigen arbeidsmarktpositie slechts marginaal kunnen verbeteren door excellent te presteren. De werkloosheidskansen van excellent presterende schoolverlaters zijn niet noemenswaardig beter dan die van hun gemiddeld presterende evenknieën. Maar wanneer MBO'ers ondergemiddeld presteren, wordt het gebrek aan prestaties wel afgestraft op de arbeidsmarkt. 


\section{Een succesvolle arbeidsmarktintrede in crisistijd: lessen van het HBO}

\subsection{Inleiding}

Het monitoren van de school-werk transitie is altijd belangrijk, maar wordt extra belangrijk in crisistijd. Veel aandacht gaat hierbij terecht uit naar groepen die extra kwetsbaar zijn, en het vorige hoofdstuk bevat een analyse van dit aspect van kwetsbaarheid bij MBO opleidingen. Het is evenwel belangrijk om niet alleen naar de negatieve kant van de crisis te kijken. Hoewel een economische crisis zoals de huidige gevolgen heeft over de volle breedte van de arbeidsmarkt, wordt niet iedereen even zwaar getroffen. Sommige schoolverlaters blijken zelf relatief goed te gedijen in deze economisch zware tijden. Wellicht kunnen waardevolle lessen worden geleerd door in te zoomen op deze schoolverlaters, met als doel het identificeren van kenmerken van opleidingen en individuen die bijdragen aan de crisisbestendigheid van deze schoolverlaters.

In dit hoofdstuk gaan we op zoek naar crisisbestendige opleidingen en afgestudeerden van het HBO. Hierbij willen we beslist niet de indruk wekken dat crisisbestendigheid uitsluitend een kenmerk is van het hoger onderwijs. In tegendeel, uit de in het vorige hoofdstuk gepresenteerde cijfers komt duidelijk naar voren dat ook een behoorlijk aantal opleidingen op middelbaar niveau zich tamelijk goed overeind hebben weten te houden in deze moeilijke tijden. De keuze om ons in dit hoofdstuk tot het HBO te beperken is vooral op praktische overwegingen gebaseerd. We beschikken over een databestand dat over de volle breedte van het $\mathrm{HBO}$ in sterke mate gestandaardiseerd is in termen van zowel kernindicatoren van arbeidsmarktsucces als mogelijke correlaties met en/of determinanten van dit succes. Ook het feit dat het niveau van de opleidingen in principe gelijk is maakt dat we uit onze analyses conclusies kunnen trekken zonder ons zorgen te hoeven maken over de vraag of de onderliggende data vergelijkbaar zijn. Een vergelijkbare analyse voor het $\mathrm{MBO}$, of een deel daarvan, zou ook zeker mogelijk zijn, maar zou vanwege onvermijdelijke verschillen in de aard van de opleidingen en de gebruikte variabelen, niet direct vergelijkbaar zijn met de $\mathrm{HBO}$-analyses.

Om misverstanden te voorkomen, willen we vooraf benadrukken dat de focus in dit hoofdstuk ligt op relatief succes in crisistijden. Zoals al is opgemerkt, heeft zo'n een zware crisis als waar we nu in zitten gevolgen over de volle breedte van de arbeidsmarkt. Er zijn weinig regelrechte winnaars in crisistijd, en dus wordt succes hier vooral gedefi- 
nieerd in termen van het inperken van schade. We gaan op zoek naar crisisbestendige $\mathrm{HBO}$-opleidingen, die gedurende de huidige crisis min of meer even succesvol zijn als in de jaren daarvoor. Zoals we zullen laten zien, is crisisbestendigheid iets anders dan succes in het algemeen, en één van de belangrijkste aandachtspunten van dit hoofdstuk is de relatie tussen algemeen arbeidsmarktsucces en crisisbestendigheid. ${ }^{20}$

Één mogelijke manier waardoor het werkloosheidspercentage onder afgestudeerden van een bepaalde opleiding kunnen worden ingeperkt, is als die afgestudeerden bereid zijn om een stap terug te nemen in termen van de eisen die worden gesteld aan de kwaliteit van de gevonden baan. Andersom kunnen de gevolgen van de crisis in termen van de kans op werk nog erger gemaakt worden dan ze wellicht hoeven te zijn, als afgestudeerden te stellig vasthouden aan de verwachting dat de eerste baan meteen in alle opzichten voldoet aan hun eisen. We gaan op zoek naar opleidingen waarvan de afgestudeerden wel tot zulke trade-offs bereid zijn gebleken, en opleidingen waar dat niet het geval is. We gaan tevens op zoek naar andere kenmerken van crisisbestendige opleidingen, en naar individuele kenmerken die samenhangen met arbeidsmarktsucces tijdens de huidige crisis.

\subsection{Effecten van de crisis op de arbeidsmarktintrede van HBO'ers}

In deze paragraaf schetsen we de belangrijkste gevolgen van de crisis voor afgestudeerden van het $\mathrm{HBO}$. We laten verschillen zien tussen opleidingssectoren in de ontwikkeling van het werkloosheidspercentage. Vervolgens vergelijken we de trend in de kans op werk met de trend in een aantal andere succesindicatoren, zowel voor het $\mathrm{HBO}$ als geheel als apart per sector. ${ }^{2 \mathrm{I}}$

Figuur 3.I laat zien dat er forse verschillen zijn tussen sectoren in de ontwikkeling van het werkloosheidspercentage vóór en ná het begin van de crisis.

20. Zoals we in figuur 3.6 zullen zien, is er weinig relatie tussen crisisbestendigheid en algemene arbeidsmarktsucces.

2I. De onderscheiden sectoren zijn: Hoger Agrarisch Onderwijs (HAO), Hoger Pedagogisch Onderwijs (HPO), Hoger Technisch Onderwijs (HTO), Hoger Economisch Onderwijs (HEO), Hoger Gezondheidszorg Onderwijs (HGZO), Hoger Sociaal-Agogisch Onderwijs (HSAO) en Hoger Kunstonderwijs (KUO). 


\section{Figuur 3.1}

Werkloosheid naar HBO-sector

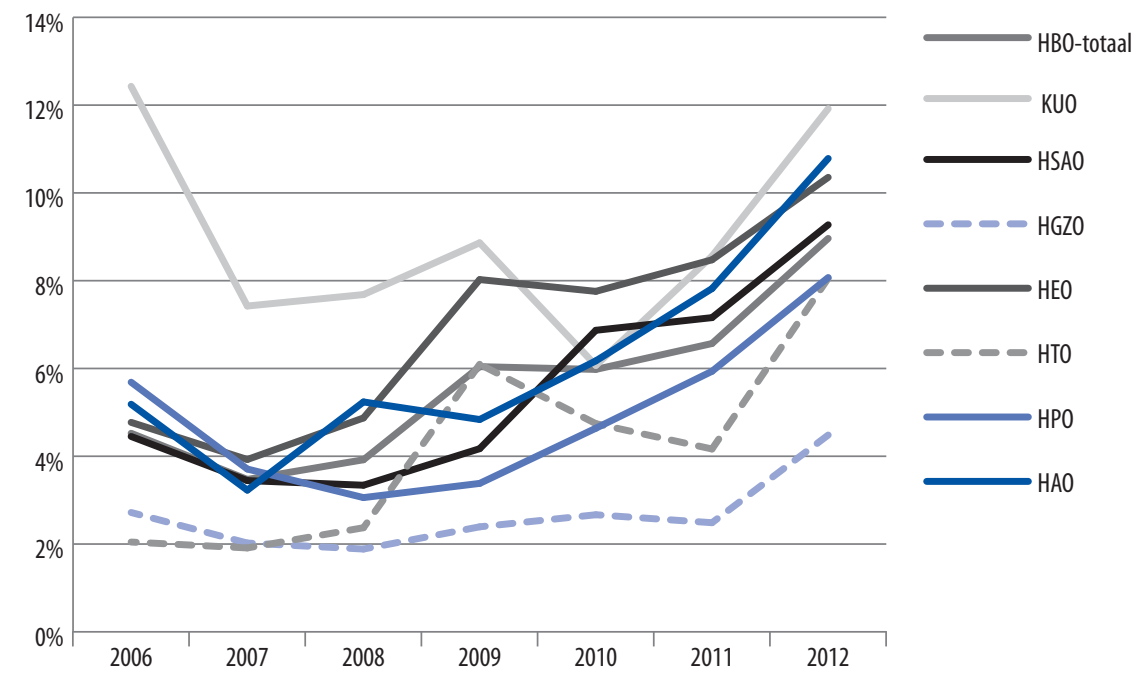

Bron: SIS (ROA), 2006-2012

Alle sectoren hebben in meer of mindere mate te maken gehad met de crisis, maar vooral het HEO, HTO en HSAO lijken zwaar te zijn getroffen. Die sectoren tonen de grootste stijging in de werkloosheid na 2008 (de crisiseffecten zijn alleen vanaf 2009 te merken). Minst zwaar getroffen is de sector HGZO, die alleen in 2012 een noemenswaardige stijging in de werkloosheid laat zien. Ook de sector KUO lijkt het relatief goed te doen, hoewel het absolute niveau van de werkloosheid veel hoger ligt.

Werkloosheid is slechts één indicator van succes in crisistijd. Wellicht is er sprake van een zekere trade-off tussen werkloosheid en baankenmerken. Loonmatiging wordt immers vaak ingezet in economisch mindere tijden om de werkgelegenheid op peil te houden, en ook in andere opzichten is het denkbaar dat sommige werknemers bereid zijn om wat in te leveren om aan het werk te kunnen, bijvoorbeeld door een tijdelijke baan, of een baan onder het eigen niveau en/of buiten de eigen richting te aanvaarden. Figuur 3.2 toont de trend in een viertal 'succesindicatoren' voor het HBO als geheel: de kans op werk (spiegelbeeld van de werkloosheid), de werkzekerheid (kans op een vaste baan), de kans op werk binnen het eigen kerndomein (werk op minimaal HBO niveau waarvoor de eigen of een verwante richting werd vereist), en uurloon. Om de vergelijking te vergemakkelijken, worden de cijfers genormaliseerd, waarbij de waarde in 2008 (net vóór de effecten van de crisis zichtbaar werden) op o is gezet. ${ }^{22}$

22. De indicatoren zijn eerst gestandaardiseerd. Hierdoor zijn de indicatoren, en de verandering hierin van jaar tot jaar, vergelijkbaar gemaakt. Vervolgens is de gemiddelde waarde per indicator in 2008 van de gestandaardiseerde indicatoren afgetrokken van het meerjarige gemiddelde. 
Figuur 3.2

Genormaliseerde trend verschillende succesindicatoren HBO-afgestudeerden $(2008=0)$

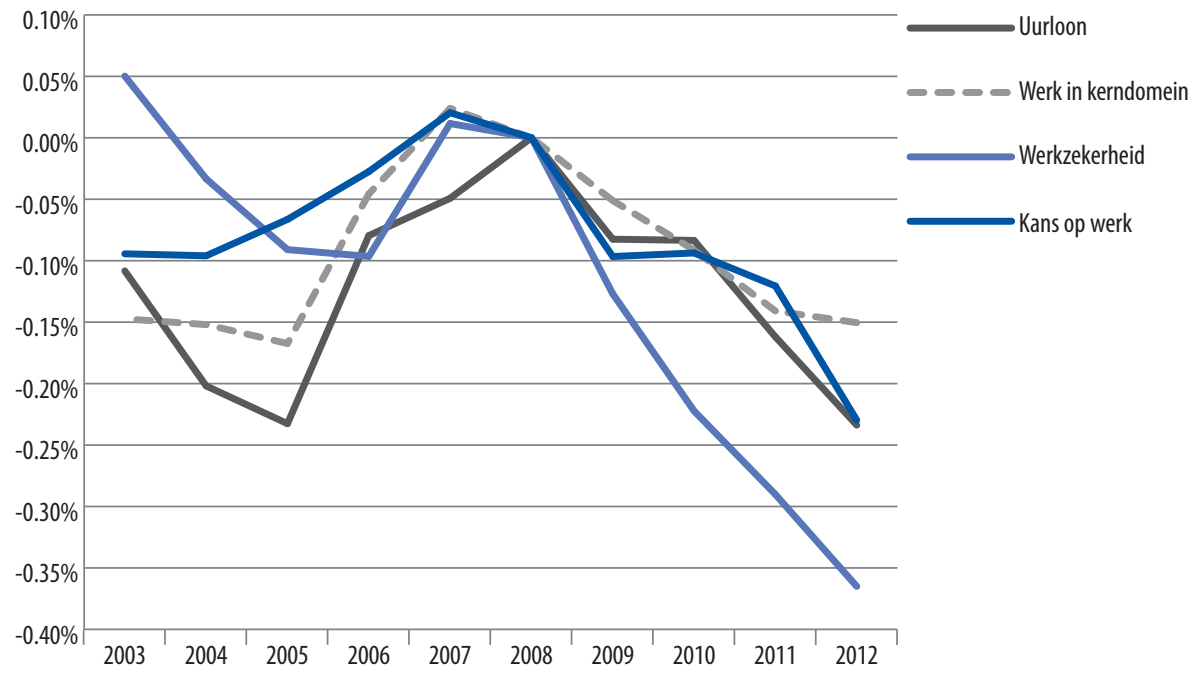

Bron: SIS (ROA), 2003-2012

Om de effecten van de crisis in een ruimere context te plaatsen worden cijfers vanaf 2003 meegenomen. Dit laat zien dat baankenmerken iets vertraagd reageren op de economische omstandigheden. Waar de kans op werk al in 2005 een duidelijke verbetering liet zien ten opzichte van 2004, nam in dezelfde periode de werkzekerheid, de kans op werk binnen het kerndomein, en de beloning nog af. De beloning lijkt ook vertraagd te reageren op het begin van de crisis: waar al in 2008 de kans op werk, werkzekerheid en werk binnen het kerndomein een pas op de plaats namen in anticipatie van de komende crisis, stegen de lonen nog fors.

Vanaf 2009 worden voor alle vier indicatoren de effecten van de crisis erg duidelijk. Dit geldt vooral voor de werkzekerheid, waar de crisis tot een versnelling heeft geleid in een schijnbaar structureel neerwaartse trend.

Wanneer we deze genormaliseerde trends per $\mathrm{HBO}$ sector bekijken (figuur 3.3) zien we een aantal opvallende verschillen. 


\section{Figuur 3.3}

Genormaliseerde trends van verschillende succesindicatoren $\mathrm{HBO}$-afgestudeerden, naar opleidingssector $(2008=0)$
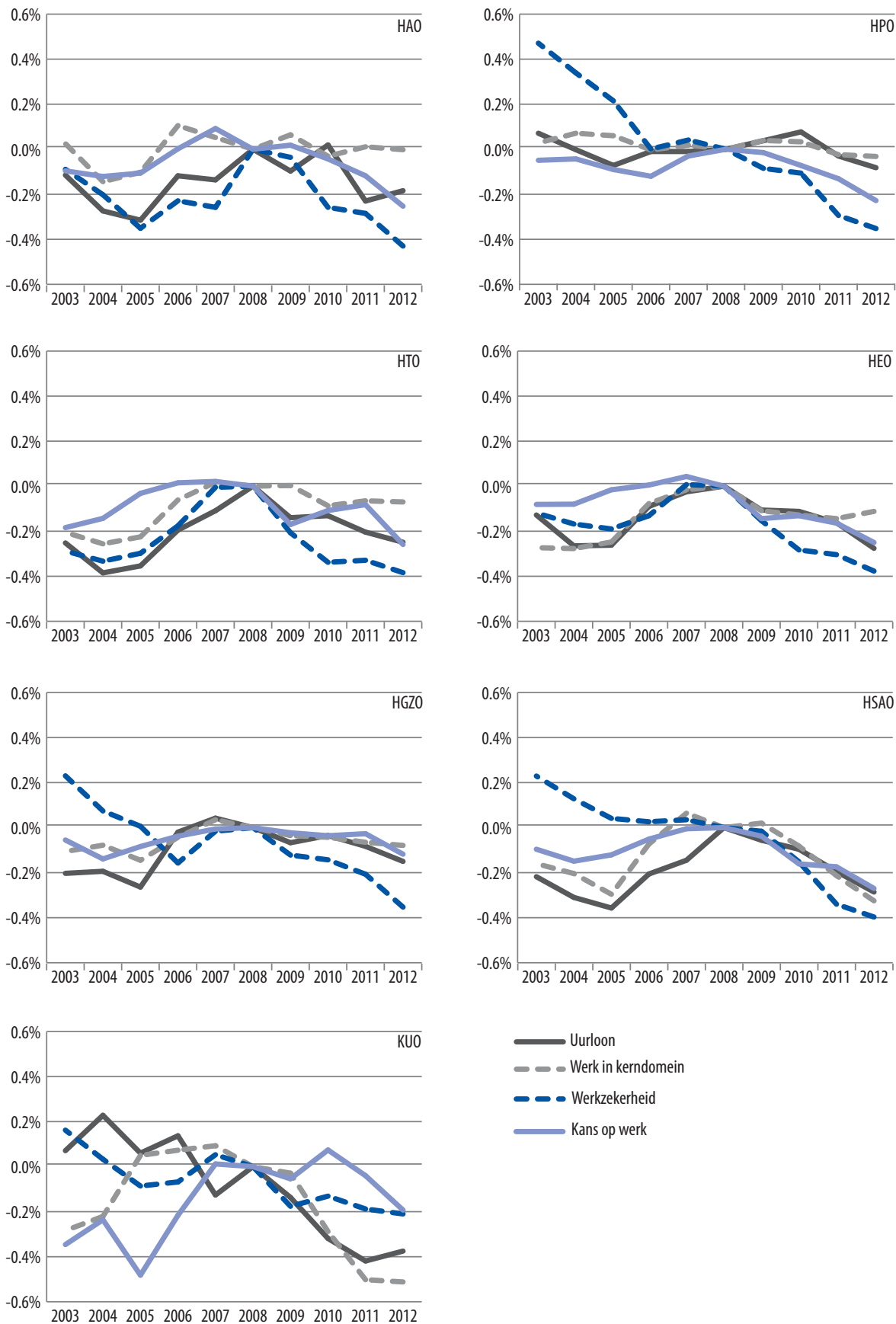

Bron: SIS (ROA), 2003-2012 
Er zijn grote verschillen in de trends, zowel naar indicator als naar sector. Het belangrijkste contrast is tussen sectoren die sterk op de private sector gericht zijn (HAO, HTO en $\mathrm{HEO}$ ), en sectoren die meer de overheidsmarkt bedienen (HPO, HGZO, HSAO en KUO). HTO, HEO en tot op zekere hoogte HAO tonen een min of meer klassiek conjunctureel patroon op alle indicatoren. Bij HPO, HGZO, HSAO en KUO domineert de structureel dalende trend in werkzekerheid de conjuncturele schommelingen, terwijl in de meer marktgerichte sectoren de conjuncturele ontwikkeling de overhand heeft. Alleen bij HSAO en KUO heeft de crisis geleid tot een grote daling in het percentage dat binnen het kerndomein werkzaam is. Bij KUO ligt de belangrijkste conjuncturele gevoeligheid juist bij het aandeel dat werkzaam is binnen het eigen kerndomein, en is de dalende trend in werkzekerheid vergezeld door een vergelijkbare daling in de beloning. Op werkzekerheid na zijn bij HPO en HGZO betrekkelijk weinig effecten van de crisis te zien, terwijl bij HSAO de veranderingen vergelijkbaar zijn met de sectoren die vooral de private sector bedienen.

De effecten van de crisis zijn dus behoorlijk verschillend, afhankelijk van de sector en de gebruikte indicator. De verschillen worden natuurlijk alleen groter wanneer we individuele opleidingen bekijken.

In het vervolg van dit hoofdstuk gaan we op zoek naar de opleidingen die het succesvolst zijn volgens de verschillende indicatoren, naar factoren die bepalende zijn voor dit succes, en naar individuele succesfactoren die een verschillende werking hebben voor afgestudeerden van succesvolle opleidingen dan voor afgestudeerden van opleidingen die minder succesvol zijn.

\subsection{Crisisbestendige opleidingen}

Zoals boven is aangegeven, wordt in dit hoofdstuk het 'succes' van opleidingen gemeten in termen van behoud en/of verbetering van de arbeidsmarktpositie van recente afgestudeerden tijdens de huidige crisis, vergeleken met de arbeidsmarktsituatie van cohorten die in de jaren vóór de crisis de opleiding verlieten. Het gaat hier om succes in termen van crisisbestendigheid. We zijn er van bewust dat dit een heel specifieke definitie is van succes, dat in principe los staat van het begrip succes in het algemeen. Opleidingen die relatief succesvol zijn in crisistijd hoeven niet dezelfde opleidingen te zijn die het in economisch goede tijden goed doen. Het is immers goed mogelijk dat er voor bepaalde opleidingen een weinig spectaculaire maar wel erg stabiele vraag bestaat. Het is zelfs denkbaar dat er sprake is van bodem-effecten, waarbij opleidingen die al in relatief goede tijden slecht presteren, niet veel verder kunnen wegzakken, terwijl opleidingen die het in goede jaren goed presteren verder kunnen vallen. We komen later terug op de relatie tussen crisisbestendigheid en succes in het algemeen.

Een tweede punt waar we in dit hoofdstuk op focussen is het feit dat succes verschillende kanten heeft. Een vergelijking van succes in termen van behoud van werkgelegenheid met 
succes in termen van werkzekerheid, aansluiting met de opleiding en beloning, kan licht werpen op mogelijke trade-offs op de arbeidsmarkt: concessies waartoe afgestudeerden van bepaalde opleidingen bereid zijn om aan het werk te kunnen gaan en blijven.

Tabel 3.I toont de top 5 opleidingen in termen van succes volgens de vier genoemde indicatoren. Zoals gezegd, wordt succes hierbij gemeten als behoud en/of verbetering na het begin van de crisis ten opzichte van de situatie voor de crisis. ${ }^{23} \mathrm{Om}$ toevalligheden als gevolg van kleine aantallen te minimaliseren, worden alleen opleidingen met minimaal IOo ongewogen cases zowel vóór als ná het begin van de crisis in de analyses meegenomen.

Hoewel sommige opleidingen tot de top 5 behoren op meer dan één indicator, zijn er geen opleidingen die tot de top behoren in alle opzichten. Dichtst in de buurt komt de opleiding Educatie en Kennismanagement Groene sector, die tot de top 5 behoort in termen van uurloon, werkzekerheid en kerndomein. Deze opleiding is ook één van de weinige opleidingen die niet achteruit is gegaan in termen van kans op werk (deze is nagenoeg constant gebleven). Deze opleiding is derhalve zonder meer als succesvol in crisistijd te benoemen, en scoort tijdens deze periode ook in absolute opzichte ruim boven gemiddeld op alle indicatoren.

Bij de meeste andere opleidingen is het beeld veel meer gemengd. Zo scoort de opleiding Creatieve Therapie goed in termen van kans op werk, maar behoort het tot de minst succesvolle opleidingen in termen van beloning en werkzekerheid. Andersom doet de opleiding Communicatiesystemen het goed in termen van beloning, maar valt op de allerlaatste plaats in termen van kans op werk en werkzekerheid. Er zijn ook veel andere opleidingen die een vergelijkbaar contrasterend beeld laten zien voor verschillende indicatoren.

We kunnen iets systematischer zien hoe de veranderingen in de verschillende indicatoren zich tot elkaar verhouden, door scatterplots te maken waarin alle opleidingen met minimaal Ioo ongewogen cases worden afgebeeld. Het is hierbij het meest interessant om te zien hoe de ontwikkeling in de kans op werk zich verhoudt tot de ontwikkeling in de drie baankenmerken. Het is immers aannemelijk dat, hoewel men in crisistijd gemiddeld gezien in alle facetten van arbeidsmarktsucces een stap achteruit moet aanvaarden, veel afgestudeerden een afweging zullen moeten maken tussen het verkrijgen van een baan op zich, en de kwaliteit van de eventuele baan die ze aanvaarden.

23. Om preciezer te zijn, gaat het om het verschil in gemiddelde score per opleiding in de meetjaren 2009-2012 in vergelijking met de meetjaren 2006-2008. Om een zuivere vergelijking te garanderen worden hogescholen die op jaarbasis onevenredig vertegenwoordigd zijn vóór of ná het begin van de crisis uit de analyses verwijderd. Hogescholen met een gemiddelde jaarlijkse omvang vóór de crisis van meer dan twee maal de gemiddelde jaarlijkse omvang ná aanvang van de crisis, en hogescholen met een gemiddelde jaarlijkse omvang ná aanvang van de crisis van meer dan twee maal de gemiddelde jaarlijkse omvang vóór de crisis, worden vooraf uit de data verwijderd. 
HOOFDSTUK 3

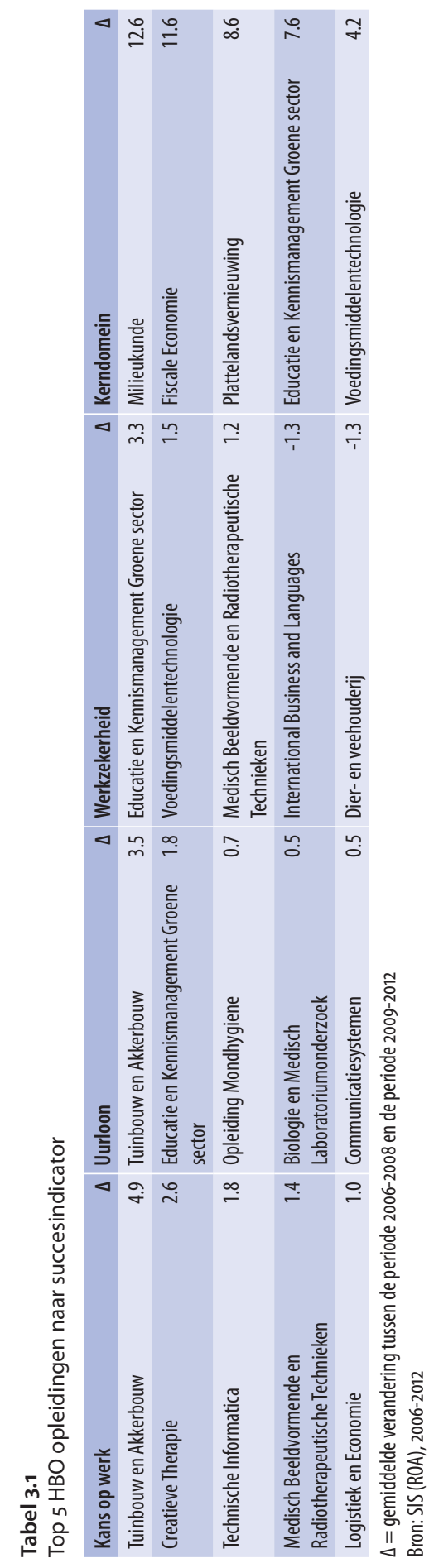


Box 3.1

Verschillen tussen technische opleidingen

Een opvallend resultaat uit tabel 3.1 is het feit dat de opleiding technische informatica een van de meest crisisbestendige opleidingen blijkt te zijn in termen van de kans op werk. We zagen immers al in figuur 3.3 dat de sector HTO, waartoe deze opleiding behoort, over de hele linie behoorlijk veel last heeft gehad van de crisis. Een interessante vraag is dus of dit voor de rest een algemeen kenmerk is van technische opleidingen, of alleen een kenmerk van een beperkt groep opleidingen.

Er is immers een deel van de arbeidsmarkt dat door de sectorHTO wordt bediend, waarvan bekend is dat die bijzonder veel last heeft gehad van de economische crisis. Het gaat om de bouwsector. Doordat de Nederlandse huizenmarkt sinds het begin van de crisis in deslopzit, hebben opleidingen die in sterke mate voor deze sectorheterg moeilijk. Figuur 3.4 toont de ontwikkeling in de tijd van de vier succesindicatoren, apart voor bouwgerelateerde en niet bouwgerelateerde opleidingen van deze sector. ${ }^{24}$

\section{Figuur 3.4}

Genormaliseerde trends van verschillende succesindicatoren HTO-afgestudeerden,bouwgerelateerde versus niet bouwgerelateerde opleidingen $(2008=0)$
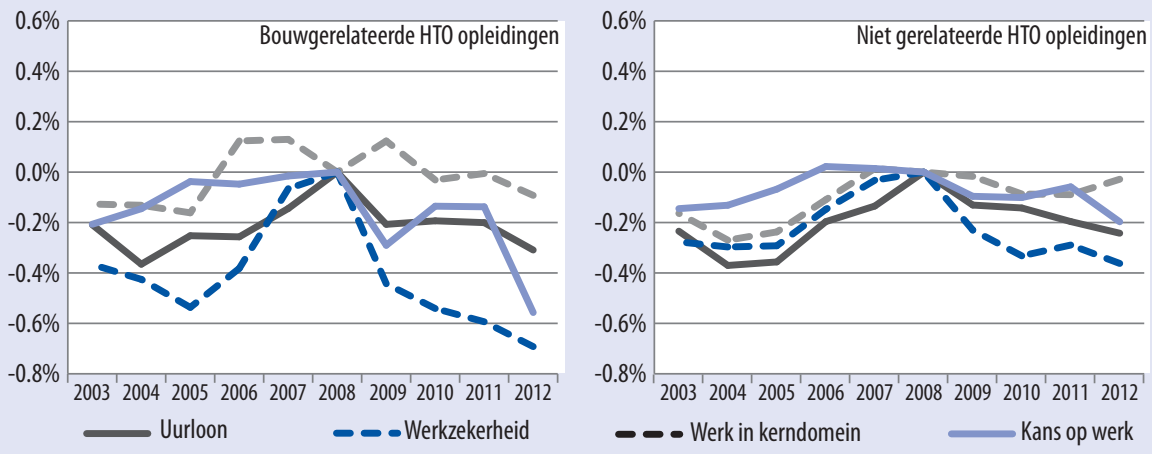

Figuur 3.4 laat zien dat bouwgerelateerde opleidingen inderdaad meer last hebben gehad van de crisis dan niet bouwgerelateerde opleidingen. Alleen de ontwikkeling van de beloning verschilt niet of nauwelijks voor de twee clusters van opleidingen. Vooral in termen van kans op werk en werkzekerheid hebben bouwgerelateerde opleidingen sinds de crisis een veel moeilijker tijd doorgemaakt dan niet bouwgerelateerde opleidingen van dezelfde sector. In termen van werkzekerheid gold ook in het verleden dat bouwgerelateerde opleidingen veel meer last hebben gehad van de conjunctuur. Er is in de periode vóór de huidige crisis echter geen noemenswaardige verschil tussen de clusters in termen van werkzekerheid.

Tenslotte, hoewel de bouwgerelateerde opleidingen duidelijk veel zwaarder door de crisis zijn getroffen, is het niet zo dat de niet bouwgerelateerde technische opleidingen geen last hebben gehad. In tegendeel, in vergelijking met bijvoorbeeld de sectoren $\mathrm{HPO}$ en $\mathrm{HGZO}$, hebben ook deze opleidingen het over de hele linie moeilijk gehad sinds het begin van de crisis.

Figuur 3.5 zet de verandering in de kans op werk af tegen de verandering in de andere drie indicatoren. De figuur laat zien dat de succesdimensies betrekkelijk onafhankelijk

24. Bouwgerelateerde opleidingen zijn opleidingen waarvan in de periode 2006-2008 minimaal $25 \%$ van de afgestudeerden in de bouw werkzaam waren. Het gaat om de opleidingen Bouwkunde, Civiele Techniek, Bouwtechnische Bedrijfskunde, en AOT Techniek. 
van elkaar zijn. Met andere woorden: opleidingen die er goed in zijn geslaagd de kans op werk van hun afgestudeerden te behouden of zelfs licht te verbeteren, zijn doorgaans niet dezelfde opleidingen die erin geslaagd zijn de baankwaliteit te behouden of verbeteren.

\section{Figuur 3.5}

Relatie tussen verandering in kans op werk en verandering in andere succesindicatoren
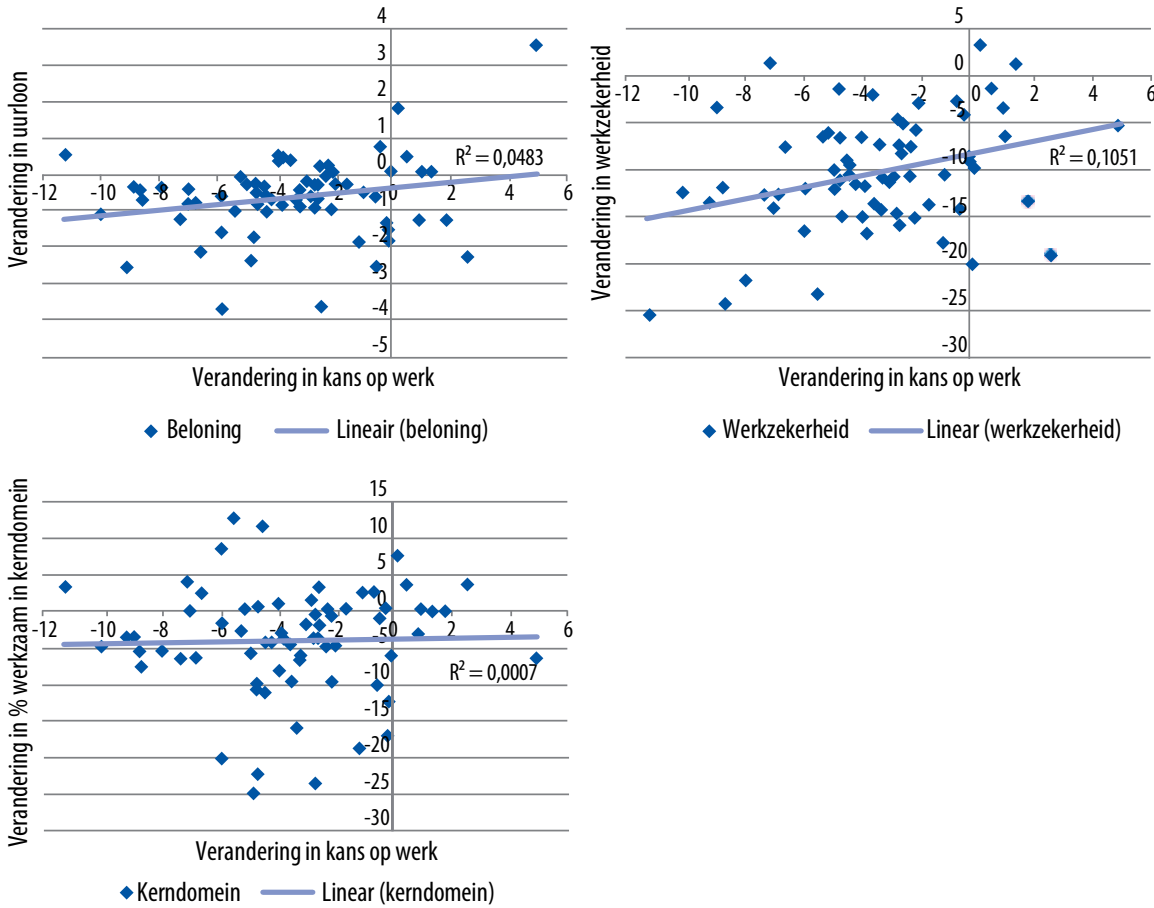

Bron: SIS (ROA), 2006-2012

De relatie is het sterkst in het geval van werkzekerheid: veel opleidingen die relatief gezien succes hebben geboekt op het gebied van werkzekerheid hebben dat vertaald gezien in succes in termen van kans op werk. Ondanks de conceptuele relatie tussen deze twee indicatoren is dit verband allerminst vanzelfsprekend. Er is in recente decennia veel aandacht voor flexibilisering van arbeidsrelaties als middel om doorstroom te bevorderen, en ruimte vrij te maken voor nieuwkomers. Er is echter weinig indicatie van deze cijfers dat afgestudeerden van sommige opleidingen een dergelijke flexibiliteit hebben getoond om hun kans op werk te vergroten. Omdat de relatie tussen de trend in kans op werk en die voor werkzekerheid vrij zwak is, kunnen we niet uitsluiten dat dit incidenteel toch is gebeurd. Er zijn afgestudeerden van enkele opleidingen die hun kans op werk hebben gehandhaafd maar fors ingeleverd hebben in termen van werkzekerheid, en ook afgestudeerden van opleidingen waar het tegenovergestelde het geval is. 
In het geval van beloning en de kans op werk in het kerndomein lijken dergelijke tradeoffs meer waarschijnlijk. Er is nagenoeg geen relatie tussen de ontwikkeling van deze indicatoren en de ontwikkeling in de kans op werk. Er is bij een behoorlijk aantal opleidingen sprake van een trade-off. Enerzijds zijn er relatief veel opleidingen waarbij behoud van kans op werk ten koste is gegaan van de baankwaliteit in termen van deze indicatoren. Anderzijds zijn er ook vrij veel opleidingen waarvan de afgestudeerden een goede baankwaliteit belangrijker lijken te hebben gevonden dan behoud van de kans op werk. Tabel 3.2 laat de opleidingen zien die het sterkste contrast laten zien in de ontwikkeling in de kans op werk in vergelijking met de indicatoren van baankwaliteit.

Tabel 3.2

Trade-offs tussen kans op werk en baankwaliteit

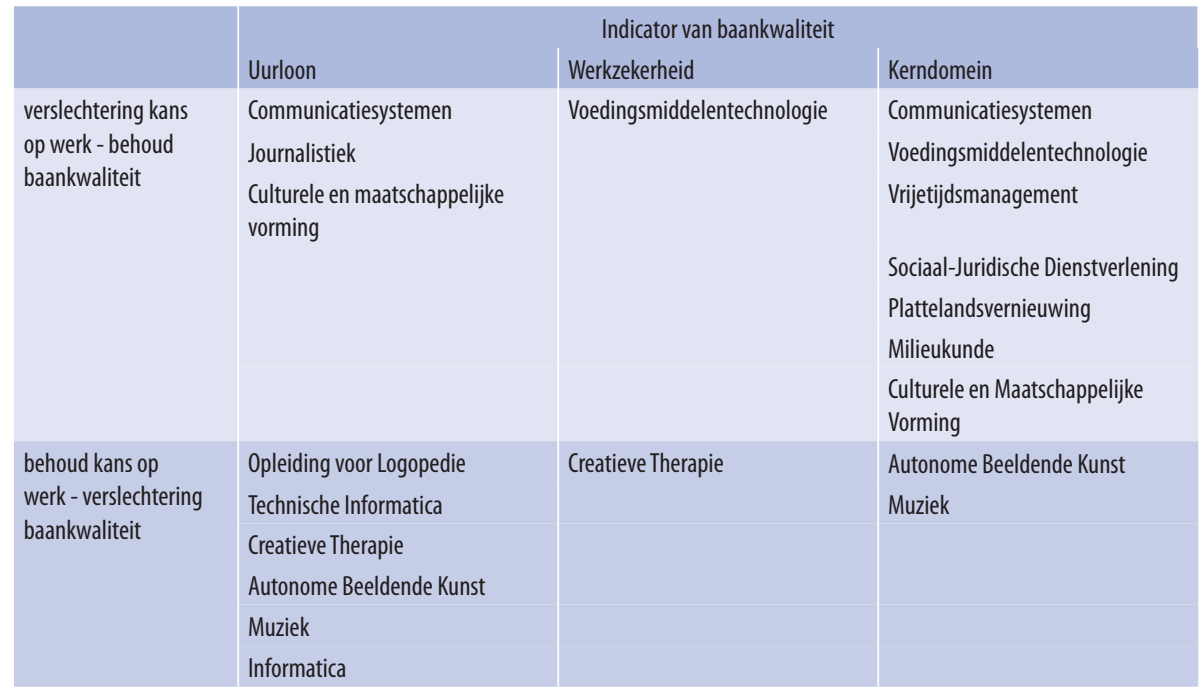

Bron: SIS (ROA), 2006-2012

Afgestudeerden van sommige opleidingen lijken het behoud van baankwaliteit dusdanig belangrijk te hebben gevonden dat ze bereid zijn geweest een verslechtering te accepteren in hun kans op werk. Er lijkt dus een trade-off plaats te vinden, waarbij bepaalde afgestudeerden niet bereid zijn om de eerste de beste baan te accepteren, en in sommige gevallen zelfs liever werkloos blijven dan in een baan te werken met een lagere kwaliteit. Bij de opleidingen Communicatiesystemen en Culturele en Maatschappelijke Vorming wordt na aanvang van de crisis een min of meer gelijk niveau behouden als de jaren daarvoor op uurloon en de kans op werk binnen het eigen kerndomein, maar wordt fors ingeleverd in termen van kans op werk. Bij de opleiding Voedingsmiddelentechnologie wordt een vergelijkbaar offer gebracht ten bate van het behoud van werkzekerheid en de kans op werk binnen het kerndomein. Bij een aantal andere opleidingen wordt behoud van één aspect van baankwaliteit geprefereerd boven behoud van kans op werk. 
Ook in de andere richting zijn er trade-offs te zien. Afgestudeerden van de opleidingen Creatieve Therapie, Autonome Beeldende Kunst, en Muziek hebben elk zich bereid getoond om op twee van de drie baankenmerken een stap achteruit te aanvaarden ter wille van het behoud van hun kans op werk. Afgestudeerden van de opleiding voor Logopedie, Technische Informatica, en Informatica hebben zich bereid getoond een lager gemiddeld loon te aanvaarden om aan extra werk te kunnen komen.

\subsection{Hebben crisisbestendige opleidingen een matige uitgangspositie?}

Zoals boven is opgemerkt wordt in dit hoofdstuk een heel specifieke definitie van 'succes' gehanteerd, dat in principe los staat van de kwestie van hoe succesvol opleidingen zijn in het algemeen. Het gaat hier immers om opleidingen die het relatief goed doen in crisistijd, in vergelijking met hoe ze het daarvoor deden. Dat betekent dat 'niet-succesvolle' opleidingen volgens deze definitie niet per se een slechte algemene arbeidsmarktpositie hebben, alleen dat ze relatief zwaar zijn getroffen door de crisis.

Het is van belang om te weten hoe 'succes' in termen van crisisbestendigheid zich verhoudt tot arbeidsmarktsucces vóór en ná het begin van de crisis. We kunnen vooraf een aantal hypotheses formuleren:

- Het zou kunnen zijn dat de zwaarste klappen tijdens een crisis bij opleidingen vallen die het vóór de crisis erg goed deden. We zouden dit de 'hoge bomen vangen meer wind' hypothese kunnen noemen.

- Het is even goed mogelijk dat het juist de opleidingen zijn die het vóór de crisis al moeilijk hadden, die het extra zwaar te verduren hebben ná het begin van de crisis. We kunnen dit de 'eens moeilijk, altijd moeilijk' hypothese noemen.

- Een derde mogelijkheid is dat het leed min of meer gelijk wordt verdeeld, waardoor een nieuw cluster opleidingen ontstaat, dat zich alleen in crisistijd van de rest onderscheidt. We noemen dit de 'crisistijgers' hypothese. ${ }^{25}$

We kunnen deze hypothese toetsen door de relatie tussen crisisbestendigheid en de situatie op dezelfde indicator vóór en ná aanvang van de crisis te bekijken:

- Wanneer de eerste hypothese geldig is, zouden we verwachten dat vooral opleidingen die vóór de crisis goede resultaten boekten op de arbeidsmarkt achteruit zijn gegaan, terwijl opleidingen die het relatief slecht deden meer crisisbestendig zijn. Dit zou leiden tot een sterk negatieve relatie tussen succes voor de crisis en crisisbestendigheid, dat bepaald wordt door het behoud van een toch tamelijk matige uitgangspositie door veel opleidingen die in het algemeen minder succesvol zijn, terwijl de doorgaans meer succesvolle opleidingen hun voorsprong (deels) kwijtraken. We zouden in dit geval een tamelijk zwakke relatie verwachten tussen

25. Het is in theorie ook mogelijk dat succes in crisistijd vooral een kwestie is van opleidingen die in crisistijd substantieel vooruit zijn gegaan. We gaan er echter voor het gemak van uit dat er betrekkelijk weinig opleidingen zijn waarvoor dit geldt, en dat succes in crisistijd vooral een kwestie is van behoud in plaats van verbetering van de situatie van opleidingen op de arbeidsmarkt. 
crisisbestendigheid en de situatie ná het begin van de crisis, omdat de verschillen tussen de succesvolste en minst succesvolle opleidingen worden verkleind.

- Wanneer de tweede hypothese correct is, zouden we verwachten dat vooral de opleidingen die vóór de crisis slechte resultaten boekten op de arbeidsmarkt achteruit zijn gegaan, terwijl opleidingen die het relatief goed deden meer crisisbestendig zijn. Dit zou leiden tot een sterk positief verband tussen succes voor de crisis en crisisbestendigheid, doordat de succesvolle opleidingen hun voorsprong ten opzichte van de minder succesvolle opleidingen vergrootten. We zouden in dit geval een nog sterkere relatie verwachten tussen crisisbestendigheid en de situatie ná het begin van de crisis, omdat de verschillen tussen de succesvolste en minst succesvolle opleidingen worden vergroot.

- Wanneer de derde hypothese geldig is, zouden we geen sterke relatie verwachten tussen crisisbestendigheid en de situatie vóór de crisis, maar een duidelijk positief verband tussen crisisbestendigheid en de situatie ná aanvang van de crisis.

Figuur 3.6 geeft hiervan een beeld.

Figuur 3.6

Relatie tussen behoud van arbeidsmarktsucces in crisistijd en de situatie vóór en ná aanvang van de crisis
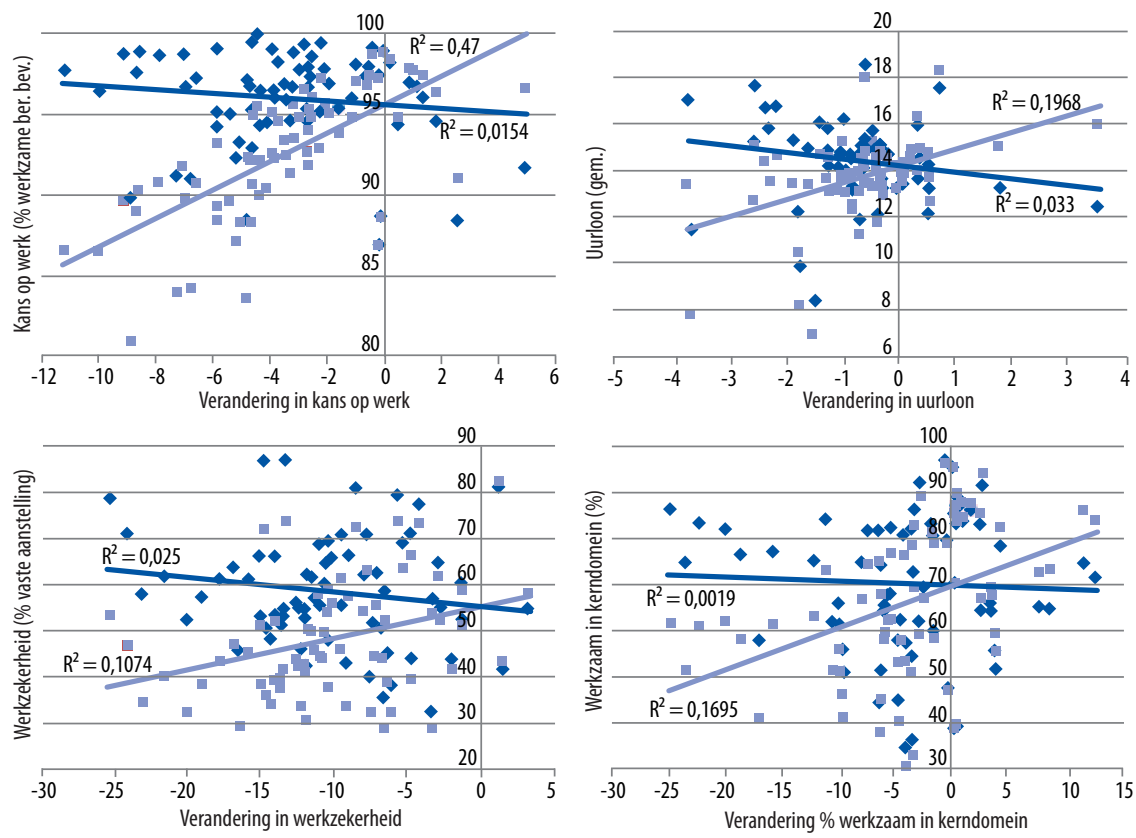

- Situatie vóór ——Lineair (situatie vóór)

- Situatie ná —Lineair (situatie ná)

Bron: SIS (ROA), 2006-2012 
Figuur 3.6 laat zien dat opleidingen die succesvol zijn tijdens een crisis echte 'crisistijgers' zijn: opleidingen die zich in economisch goede tijden niet of nauwelijks van andere opleidingen onderscheidden, maar die tijdens de crisis veel beter in staat zijn gebleken hun arbeidsmarktpositie te behouden. Er is nauwelijks een relatie tussen crisisbestendigheid en succes vóór de crisis. Weliswaar is in alle vier gevallen een licht negatief verband waarneembaar, maar dit is waarschijnlijk eerder een kwestie van plafond- en/of bodemeffecten dan van veel zwaardere klappen bij de opleidingen die voorheen succesvol waren. ${ }^{26}$ Ook het feit dat de spreiding tussen opleidingen groter wordt ná het begin van de crisis lijkt hiervan een bevestiging. Wanneer opleidingen die succesvoller waren vóór de crisis werkelijk harder waren getroffen, zouden we eerder een afname verwachten in de verschillen tussen opleidingen.

In het vervolg wordt aan de hand van een serie multivariate analyses nagegaan welke kenmerken van opleidingen met succes tijdens de crisis samenhangen, en welke kenmerken van individuele afgestudeerden het beste werken in crisistijd of juist in rustiger tijden.

\subsection{Wat maakt een opleiding crisisbestendig?}

In deze paragraaf wordt een aantal regressieanalyses gepresenteerd die als doel hebben om de kenmerken te bepalen van opleidingen die relatief goed uit de crisis zijn gekomen. Zoals we al hebben gezien is deze crisisbestendigheid tamelijk onafhankelijk van succes in het algemeen. Er lijkt geen systematisch verschil te zijn tussen crisisbestendige- en nietcrisisbestendige opleidingen in termen van hoe ze het vóór de crisis deden op dezelfde indicator. Dat betekent dat de in deze paragraaf gepresenteerde analyses dus nadrukkelijk niet bedoeld zijn om factoren die van belang zijn voor algemeen arbeidsmarktsucces bloot te leggen.

De eenheden in deze analyses zijn HBO-opleidingen. De afhankelijke variabelen in deze regressies zijn de bovenstaande succesmaten per opleiding. Voorspellers zijn gemiddelde kenmerken van de opleidingen in de gehele periode 2006-20I2.

Vooraf dient te worden opgemerkt dat het hier niet per se om causale relaties gaat. Hoewel in sommige gevallen een bepaalde mate van causaliteit aannemelijk is, gaat het hier in eerste instantie om het identificeren van kenmerken van opleidingen die met crisisbestendigheid samenhangen. Tabel 3.3 toont de resultaten. ${ }^{27}$

26. Wanneer de hoogste en laagste waarden vóór de crisis worden weggehaald, worden de lijnen nagenoeg horizontaal.

27. De volledige resultaten staan in tabel $\mathrm{B}_{3.3}$ in Bijlage 2. Mensen die doorgestroomd zijn naar een vervolgopleidingen worden buiten beschouwing gelaten. Alleen opleidingen met minstens 20 waarnemingen zowel vóór als ná aanvang van de crisis worden meegenomen. Cases zijn neutraal gewogen naar het aantal waarnemingen per opleiding in de periode 2006-20I2, dat wil zeggen grotere opleiding wegen zwaarder dan kleine opleidingen, maar het totaal aantal opleidingen blijft gelijk ná de weging. Indicatoren die geen significant effecten hadden op minimaal Io\% niveau in tenminste één analyse zijn verwijderd uit het model. 
Wat betreft opleidingssectoren blijkt HGZO over de hele linie tot nu toe goed door de crisis te zijn gekomen. Voor deze sector is alleen het effect op kans op werk in het kerndomein niet significant. HSAO doet het goed in termen van kans op werk en beloning, maar iets slechter dan HEO in termen van kans op werk binnen het kerndomein. HPO doet het iets beter dan HEO in dat opzicht.

De samenstelling van opleidingen in termen van geslacht en etniciteit blijkt ook een relatie te vertonen met crisisbestendigheid. Hoewel in veel opzichten de typische 'mannensectoren' zoals HEO en HTO veel last hebben gehad van de crisis, blijkt dat nadat we voor geslacht hebben gecontroleerd, opleidingen met relatief veel vrouwen juist minder goed door de crisis te zijn gekomen. Alleen het effect op kans op werk in het kerndomein is niet significant. Opleidingen met relatief veel niet-westerse allochtonen hebben een iets minder gunstige ontwikkeling in termen van kans op werk, maar doen het in andere opzichten niet beter of slechter dan opleidingen met weinig allochtonen.

\section{Tabel 3.3}

Resultaten van regressieanalyse, afhankelijke variabele verandering in succesmaat ná aanvang van de crisis ten opzichte van de situatie vóór de crisis

\begin{tabular}{|c|c|c|c|c|}
\hline & Kans op werk & Uurloon & Werkzekerheid & Kerndomein \\
\hline \multicolumn{5}{|l|}{ Opleidingssector (ref. HEO) } \\
\hline \multicolumn{5}{|l|}{ HAO } \\
\hline HPO & & & & + \\
\hline \multicolumn{5}{|l|}{ HTO } \\
\hline$H G Z O$ & +++ & +++ & +++ & \\
\hline HSAO & ++ & +++ & & - \\
\hline \multicolumn{5}{|l|}{ KUO } \\
\hline$\%$ vrouwen & --- & --- & -- & \\
\hline$\%$ niet-westerse allochtonen & - & & & \\
\hline \multicolumn{5}{|l|}{ Balansvragen: } \\
\hline moeilijkheidsgraad & - & - & -- & \\
\hline verhouding theorie-praktijk & --- & & & \\
\hline Selectiviteit & + & ++ & +++ & \\
\hline \multicolumn{5}{|l|}{ Rapportcijfers: } \\
\hline aansluiting actuele ontwikkelingen & & - & -- & \\
\hline Voorbereiding op beroepspraktijk & +++ & +++ & + & \\
\hline Docenten (3 items) & & - & & \\
\hline Stand op succesindicator vóór de crisis & --- & --- & --- & \\
\hline $\begin{array}{ll}\text { Bron: SIS } & \text { (ROA) } 2006-2012 \\
+++/--- & \text { positief/negatief significant op 1\% niveau } \\
++/-- & \text { positief/negatief significant op 5\% niveau } \\
+/- & \text { positief/negatief significant op } 10 \% \text { niveau }\end{array}$ & & & & \\
\hline
\end{tabular}

Opleidingen die als te moeilijk worden ervaren hebben een iets minder gunstige ontwikkeling dan opleiding die als te gemakkelijk worden ervaren. Hierbij dient te worden opgemerkt dat dit het effect is na controle op het gemiddelde oordeel van afgestudeerden 
op onder andere selectiviteit en voorbereiding op beroepspraktijk. Het effect verdwijnt wanneer hiervoor niet wordt gecontroleerd. De interpretatie lijkt te zijn dat na controle voor deze oordelen, die een positief effect hebben op de crisisbestendigheid van opleidingen, opleidingen waarvan veel studenten de stof te moeilijk vinden iets zwaardere klappen kregen tijdens de crisis dan opleidingen waarbij dit niet het geval was.

Opleidingen die als te praktijkgericht worden ervaren komen minder goed door de crisis in termen van kans op werk dan opleidingen die als te theoretisch worden ervaren. Het is belangrijk om hierbij op te merken dat ook dit effect pas significant wordt na controle op andere kenmerken, met name het oordeel over de opleiding in termen van voorbereiding op beroepspraktijk. Opleidingen die als te praktijkgericht worden gezien worden over de hele linie beter beoordeeld in termen van voorbereiding op beroepspraktijk dan opleidingen die als te theoretisch worden beoordeeld. Na controle hiervoor blijkt het effect dus negatief. De interpretatie lijkt te zijn dat voor zover als de praktijkgerichtheid niet bijdraagt aan deze voorbereiding, meer nadruk hierop gepaard gaat met een verminderde crisisbestendigheid.

Zoals gezegd komen selectievere opleidingen beter door de crisis dan minder selectieve opleidingen, evenals opleidingen die goed worden beoordeeld in termen van voorbereiding op beroepspraktijk. Echter, opleidingen die goed worden beoordeeld in termen van aansluiting op ontwikkelingen in het vakgebied doen het iets slechter. Opleidingen waarvan de docenten goed worden beoordeeld maken een iets minder gunstige loonontwikkeling door dan opleidingen waarvan de docenten minder goed worden beoordeeld.

Met uitzondering van kans op werk heeft de situatie op de arbeidsmarkt vóór de crisis een negatief effect op de ontwikkeling ná het begin van de crisis. Zoals boven is opgemerkt is dit waarschijnlijk vooral een kwestie van vloer- en plafondeffecten (vgl. figuur 3.6).

\subsection{Wat is bepalend voor individueel succes in crisistijd?}

$\mathrm{Nu}$ stappen we over op individuele kenmerken die bepalend zijn voor succes. Hierbij staan twee vragen centraal. De eerste is erg eenvoudig: welke kenmerken van individuele afgestudeerden hangen het sterkst samen met arbeidsmarktsucces sinds de crisis is begonnen? De tweede vraag is iets subtieler: zijn deze individuele succeskenmerken anders voor afgestudeerden van crisisbestendige opleidingen dan voor afgestudeerden van opleidingen van opleidingen die zwaarder door de crisis zijn getroffen? Vooral voor de laatste groep afgestudeerden is dit een belangrijke vraag. Deze afgestudeerden zijn door hun gekozen opleiding namelijk erg kwetsbaar in crisistijden. Het is van belang om te weten welke kenmerken deze kwetsbaarheid vergroten, en welke kenmerken hun juist helpen een bevredigend resultaat te boeken op de arbeidsmarkt, ondanks hun opleidingskeuze. 
Het analysedesign is als volgt: een aantal regressieanalyses is gedraaid, met als controlevariabelen sector-dummies, en als voorspellers geselecteerde kenmerken van individuele afgestudeerden: geslacht, leeftijd, etniciteit, vooropleiding, eindcijfer, ervaring tijdens opleiding, scholing, studieregio, werken in een klein versus groot bedrijf. Voor alle voorspellers wordt een interactieterm opgenomen met succesmaat behorend bij de betreffende afhankelijke variabele. ${ }^{28}$ Dit geeft aan of het betreffende kenmerk beter of slechter werkt voor afgestudeerden van opleidingen die over de hele linie succesvol zijn in crisistijd. De analyses hebben betrekking op de jaren 2009-20I2 (na het begin van de crisis dus). Tabel 3.4 vat de belangrijkste effecten samen (zie tabellen $\mathrm{B}_{3} .4 \mathrm{a}-\mathrm{d}$ in bijlage 2 voor de volledige resultaten).

Al bij een eerste blik valt een aantal algemene punten op in tabel 3.4. Om te beginnen zijn er meer hoofdeffecten dan interactie-effecten. Dat neemt niet weg dat er ook vrij veel significante interacties zijn. Deze interacties vallen meestal - maar niet uitsluitend - samen met significante hoofdeffecten. In vrijwel alle gevallen waar zowel hoofdeffect als interactie significant is, gaan de effecten in dezelfde richting, hetgeen betekent dat het vooral om effecten gaat voor afgestudeerden van crisisbestendige opleidingen. Verder blijkt dat de effecten uiteen vallen in effecten die min of meer hetzelfde zijn voor alle vier succesindicatoren, effecten die in verschillende richtingen wijzen voor verschillende succesindicatoren, en effecten die alleen gelden voor één succesindicator.

Als we meer specifiek kijken naar de geschatte effecten, zien we een aantal interessante patronen. Om bij positieve effecten te beginnen, zien we dat de algemeen positieve effecten - significante hoofdeffecten in afwezigheid van interactie-effecten, die dus voor afgestudeerden van crisisbestendige en niet-crisisbestendige opleidingen in gelijke mate gelden - vooral kenmerken zijn waarvan gedacht wordt dat ze met het menselijk kapitaal van afgestudeerden samenhangen. Relevante werkervaring heeft een positief effect op alle indicatoren, bestuurlijke ervaring hangt positief samen met de kans op werk en uurloon, buitenlandse studie-ervaring op kans op werk in eigen kerndomein, gemiddeld eindcijfer op kans op werk en werkzekerheid, na-/bijscholing op uurloon en kans op werk in eigen kerndomein. Het enige algemeen positieve effect dat geen relatie heeft met menselijk kapitaal is het effect van een westers allochtone etniciteit op werkzekerheid.

Een aantal effecten blijkt extra sterk positief te werken voor afgestudeerden van crisisbestendige opleidingen, hetgeen blijkt uit een positief hoofdeffect in combinatie met een positief interactie-effect. Ook hier gaat het vaak om zaken waarvan een relatie met menselijk kapitaal kan worden verondersteld: een effect van leeftijd op uurloon, van buitenlandse stage op werkzekerheid, en van na-/bijscholing op kans op werk.

Andersom zijn er effecten die juist extra sterk positief gelden voor afgestudeerden van niet-crisisbestendige opleidingen, hetgeen blijkt uit een positief hoofdeffect in combi-

28. Om interpretatie van de resultaten te vereenvoudigen, zijn de indicatoren die de verandering in de succesmaten aangeven, vooraf gestandaardiseerd. Dit betekent dat deze maten een gemiddelde waarde van o hebben, en een standaarddeviatie van I. 
natie met een negatieve interactie. Ook hier is de veronderstelde relatie met menselijk kapitaal meestal aanwezig. Het effect van leeftijd op werkzekerheid, van cijfers op uurloon en kans op werk in eigen kerndomein, en van na-/bijscholing op werkzekerheid. Het enige effect zonder duidelijk verband met menselijk kapitaal is het effect van werken in een groot bedrijf op uurloon.

\section{Tabel 3.4}

Resultaten van (logistische) regressieanalyses, afhankelijke variabele kans op werk, uurloon, werkzekerheid, en kans op baan in kerndomein

\begin{tabular}{|c|c|c|c|c|c|c|c|c|}
\hline & \multicolumn{2}{|c|}{ Kans op werk } & \multicolumn{2}{|c|}{ Uurloon } & \multicolumn{2}{|c|}{ Werkzekerheid } & \multicolumn{2}{|c|}{ Kerndomein } \\
\hline & Hoofd & Interactie & Hoofd & Interactie & Hoofd & Interactie & Hoofd & Interactie \\
\hline Geslacht: vrouw & & & --- & & --- & --- & --- & \\
\hline Leeftijd & --- & & +++ & ++ & +++ & - & --- & --- \\
\hline \multicolumn{9}{|l|}{ Etniciteit (ref. autochtoon) } \\
\hline westerse allochtoon & & & & - & +++ & & & - \\
\hline niet-westerse allochtoon & --- & & & & --- & & - & \\
\hline \multicolumn{9}{|c|}{ Hoogst voltooide vooropleiding (ref. VW0) } \\
\hline HAVO & & & & & & & --- & \\
\hline MBO & & & & & & & --- & \\
\hline \multicolumn{9}{|l|}{ anders } \\
\hline Gemiddeld eindcijfer & +++ & & +++ & --- & +++ & & +++ & -- \\
\hline \multicolumn{9}{|l|}{ Ervaring tijdens $\mathrm{HBO}$ opleiding } \\
\hline stage in buitenland & & & & & +++ & +++ & --- & + \\
\hline rel. werkervaring (behalve stage) & +++ & & +++ & & +++ & & +++ & \\
\hline buitenlands studieonderdeel & & & & & & & ++ & \\
\hline bestuurlijke ervaring & + & & ++ & & & +++ & & \\
\hline $\mathrm{Na}-/$ bijscholing gevolgd & +++ & ++ & +++ & & +++ & -- & +++ & \\
\hline \multicolumn{9}{|l|}{ Regio opleiding (ref. west): } \\
\hline noord & & & -- & & --- & +++ & - & \\
\hline oost & & & --- & & --- & +++ & & \\
\hline zuid & & - & --- & & --- & +++ & & \\
\hline \multicolumn{9}{|l|}{ Bedrijfsgrootte } \\
\hline klein & nvt & nvt & & +++ & & -- & & -- \\
\hline groot & nvt & nvt & +++ & - & --- & & --- & \\
\hline Verandering succesindicator na crisis & & nvt & ++ & nvt & & nvt & +++ & nvt \\
\hline
\end{tabular}

Bron: SIS (ROA) 2006-2012

$+++/---$ positief/negatief significant op $1 \%$ niveau

$++/--\quad$ positief/negatief significant op 5\% niveau

+/- $\quad$ positief/negatief significant op $10 \%$ niveau

Anders dan positieve effecten zijn algemeen negatieve effecten meestal geen attributen met een duidelijke relatie met menselijk kapitaal. Het gaat hier juist vooral om persoons-, onderwijs- en bedrijfskenmerken: het effect van geslacht op uurloon en kans op werk in eigen kerndomein, van leeftijd op kans op werk, van niet-westerse allochtoon op alles behalve loon, van vooropleiding op kans op werk in eigen kerndomein, van regio (afstu- 
deren buiten het westen) op uurloon en in veel mindere mate kans op werk in eigen kerndomein, en van het werken in een groot bedrijf op werkzekerheid en kans op werk in eigen kerndomein. ${ }^{29}$

Effecten die extra sterk negatief gelden voor afgestudeerden van crisisbestendige opleidingen zijn het effect van geslacht op werkzekerheid, en van leeftijd op kans op werk in eigen kerndomein. Effecten die juist extra sterk negatief gelden voor afgestudeerden van niet-crisisbestendige opleidingen zijn het effect van buitenlandse stages op kans op werk in eigen kerndomein, en van regio op werkzekerheid.

Naast effecten die als overwegend positief of negatief kunnen worden bestempeld, is er een klein aantal effecten waarvoor er geen significant hoofdeffect bestaat, maar wel een interactie-effect. Wanneer in zulke gevallen het interactie-effect positief is, betekent dat dat het effect positief is voor afgestudeerden van crisisbestendige opleidingen en negatief voor afgestudeerden van niet-crisisbestendige opleidingen. De effecten waarvoor dat geldt zijn dat van bestuurlijke ervaring op werkzekerheid, en van het werken in een klein bedrijf op uurloon.

Effecten die negatief zijn voor afgestudeerden van crisisbestendige opleidingen en positief voor afgestudeerden van niet-crisisbestendige opleidingen zijn dat van westerse allochtoon op uurloon en kans op werk in eigen kerndomein, van het afstuderen in het zuiden op de kans op werk, en van het werken in een klein bedrijf op werkzekerheid en de kans op werk in eigen kerndomein. $\mathrm{Al}$ deze effecten zijn zwak of zelfs zeer zwak.

\subsection{Conclusies}

In dit hoofdstuk zochten we naar kenmerken van crisisbestendige opleidingen en afgestudeerden van het $\mathrm{HBO}$. De focus lag hierbij vooral op relatief succes in crisistijden, dat wil zeggen, een mate van succes dat vergelijkbaar is met wat wordt bereikt door afgestudeerden van dezelfde opleidingen in economisch betere tijden. We keken hierbij niet alleen naar de kans op werk, maar ook naar een aantal indicatoren van baankwaliteit: uurloon, werkzekerheid en de kans op werk binnen het eigen kerndomein.

Er zijn opvallende verschillen tussen $\mathrm{HBO}$ sectoren in de mate waarin en de manier waarop ze door de crisis, en meer in het algemeen door de conjunctuur, worden beïnvloed. Het belangrijkste contrast bevindt zichtussen sectoren die sterk op de private sector gericht zijn (HAO, HTO en HEO), en sectoren die meer de overheidsmarkt bedienen

29. Er dient hierbij te worden opgemerkt dat de negatieve richting van de meeste van deze effecten bepaald wordt door de keuze van referentiecategorie: mannen, autochtonen, het westen, afgestudeerden met een VWO vooropleiding. Alleen leeftijd heeft een inherente richting, en het negatief effect hiervan op kans op werk is bekend. Werkgevers geven vaak de voorkeur aan jongere baankandidaten boven oudere mensen met gelijke kwalificaties, te meer omdat ze vaak gedwongen zouden zijn om de oudere mensen een hoger loon te betalen. 
(HPO, HGZO, HSAO en KUO). HTO, HEO en tot op zekere hoogte HAO tonen een min of meer klassieke conjunctureel patroon op alle succesindicatoren. Bij HPO, $\mathrm{HGZO}, \mathrm{HSAO}$ en KUO wijkt de trend in de indicator werkzekerheid af van die van de overige succesindicatoren, in de zin dat er eerder sprake lijkt te zijn van een langdurig dalende lijn dan van conjuncturele schommelingen. In andere opzichten lijken het HPO en het HGZO betrekkelijk weinig effecten van de crisis te zien, terwijl bij HSAO de veranderingen vergelijkbaar zijn met de sectoren die vooral de private sector bedienen. Bij KUO ligt de belangrijkste conjuncturele gevoeligheid juist bij het aandeel werkzaam binnen het eigen kerndomein, en is de dalende trend in werkzekerheid vergezeld door een vergelijkbare daling in de beloning.

Het lijkt alsofer bij sommige opleidingen sprake is van een trade-offtussen de kans op werk en baankwaliteit. Afgestudeerden van sommige opleidingen, zoals Communicatiesystemen, Culturele en Maatschappelijke Vorming Voedingsmiddelentechnologieën, lijken het behoud van baankwaliteit dusdanig belangrijk te hebben gevonden dat ze bereid zijn geweest een verslechtering te accepteren in hun kans op werk. Afgestudeerden van opleidingen zoals Creatieve Therapie, Autonome Beeldende Kunst, en Muziek daarentegen hebben zich juist bereid getoond om in termen van baankwaliteit een stap terug te aanvaarden ter wille van het behoud van hun kans op werk.

Opleidingen die succesvol zijn tijdens een crisis zijn als echte 'crisistijgers' te bestempelen: opleidingen die zich in economisch goede tijden niet of nauwelijks van andere opleidingen onderscheiden, maar die tijdens de crisis veel beter in staat zijn gebleken hun arbeidsmarktpositie te behouden dan andere opleidingen. Er is nauwelijks een relatie tussen crisisbestendigheid en succes vóór de crisis. Hieruit kunnen we concluderen dat noch de 'hoge bomen', noch de opleidingen die het structureel moeilijker hebben, onevenredig zwaar door de crisis zijn getroffen, en dat er sprake is van 'crisistijgers'.

Wanneer we kijken naar andere kenmerken van crisisbestendige opleidingen vallen een aantal sterke verbanden op. Hoewel in veel opzichten de typische 'mannensectoren' zoals $\mathrm{HEO}$ en HTO veel last hebben gehad van de crisis, blijkt dat nadat we voor geslacht hebben gecontroleerd, opleidingen met relatief veel vrouwen juist minder goed door de crisis te zijn gekomen. Verder blijken opleidingen die door hun afgestudeerden als relatief selectief en/of goed worden beoordeeld in termen van voorbereiding op beroepspraktijk, goed door de crisis te zijn gekomen.

Ten slotte hebben we gekeken naar individuele kenmerken die behulpzaam zijn gebleken voor een succesvolle transitie naar de arbeidsmarkt, of die deze transitie juist bemoeilijken. Opvallend hierbij was het feit dat de meeste positieve effecten kenmerken waren waarvan gedacht wordt dat ze met het menselijk kapitaal van afgestudeerden samenhangen, zoals verschillende soorten ervaring, gemiddeld eindcijfer, en na-/bijscholing. In sommige gevallen leken deze effecten sterker te werken voor afgestudeerden van crisisbestendige opleidingen, terwijl het soms juist afgestudeerden van niet crisisbestendige 
opleidingen waren die hier het meest profijt van hadden, maar over de hele linie leken het meer om algemene effecten te gaan die voor iedereen gunstig uitpakten.

Anders dan positieve effecten zijn algemeen negatieve effecten meestal geen attributen met een duidelijke relatie met menselijk kapitaal. Het gaat hier juist vooral om persoons-, onderwijs- en bedrijfskenmerken: het effect van geslacht, etniciteit, vooropleiding, studieregio, en bedrijfsgrootte.

Strikt gesproken kunnen geen van de hier genoemde effecten als causaal worden beschouwd. Er zijn immers andere factoren - met naam factoren aan de vraagkant van de markt waarvoor niet kom worden gecontroleerd. Desalniettemin lijkt plausibel dat met name de effecten van de verschillende soorten menselijk kapitaal in ieder geval voor een deel als causaal kunnen worden beschouwd. In het geval van kenmerken als geslacht en etniciteit ligt dat anders, en kan zeker worden gediscussieerd over de vraag waar deze effecten aan liggen. In de context van dit rapport kan alleen worden vastgesteld dat vrouwen en allochtonen over de hele linie een moeilijker transitie naar de arbeidsmarkt hebben dan mannen c.q. autochtone. In het geval van studieregio en bedrijfsgrootte is vrijwel zeker dat de effecten zich vooral met aspecten van de vraag naar arbeid te maken hebben. 



\section{Literatuur}

Borghans, L., de Grip, A. (2000), The Overeducated worker?: the economics of skill utilization, Edward Elgar Publishing Limited, UK.

Breen, R. (2005). Explaining Cross-national Variation in Youth Unemployment: Market and Institutional Factors, European Sociological Review 21(2):125-34.

Breen, R. and J.O. Jonsson. (2005). "Inequality of Opportunity in Comparative Perspective: Recent Research on Educational Attainment and Social Mobility”, Annual Review of Sociology, Vol. 31, pp. 223-43.

CBS. (2013). Sterke stijging werkloosheid. Persbericht, donderdag 21 februari 2013 9:30

Meng, C., T. Huijgen en G. Ramaekers (2009), MBO-diploma in tijden van crisis. Doorleren of werk zoeken? Maastricht: ROA.

Ministerie van Onderwijs, Cultuur en Wetenschap (2012), Doorstroomatlas VMBO: De onderwijsloopbanen van vmbo'ers in kaart gebracht.

Mooij, T., \& Fettelaar, D. (2010). Naar excellente scholen, leraren leerlingen en studenten,. Nijmegen, ITS, in opdracht van de onderwijsraad

Lin, N. (1999). Building a Network Theory of Social Capital Connections, 22 (1), 28-51.

OECD (2012). OECD Employment Outlook 2012. Paris: OECD Publishing.

Researchcentrum voor Onderwijs en Arbeidsmarkt (2013). Voortijdige schoolverlaters, ROAF-2013/3, Researchcentrum voor Onderwijs en Arbeidsmarkt, Maastricht.

Spence, M. (1973). Job Market Signaling. Quarterly Journal of Economics, 87(1):355-374.

Van Tubergen, F. (2006). Immigrant Integration: A Cross-National Study. New York: LFB Scholarly Publishing.

Wolbers, M. (2003). Job mismatches and their labor market effects among school-leavers in Europe. European Sociological Review, 19: 249-266. 



\section{Bijlage 1:Tabellen hoofdstuk 2}

Tabel B 2.8

Logitanalyse op arbeidsmarktprestaties van MBO-gediplomeerden, behorende bij tabellen 2.8 en 2.9 van hoofdstuk 2

\begin{tabular}{|c|c|c|c|c|c|}
\hline & werkloos & $\begin{array}{l}\text { intrede- } \\
\text { werkloosheid } \\
>12 \text { mnd }\end{array}$ & overeducatie & $\begin{array}{c}\text { horizontale } \\
\text { mismatch }\end{array}$ & verder leren- \\
\hline \multicolumn{6}{|l|}{ Opleiding } \\
\hline \multicolumn{6}{|l|}{ BBL (ref.) } \\
\hline BOL & $0,842 * * *$ & $1,387^{* * *}$ & $-0,195^{* * *}$ & $0,271^{* * *}$ & $0,725^{* * *}$ \\
\hline \multicolumn{6}{|l|}{ MB02 (ref.) } \\
\hline MBO3 & $-0,415^{* * *}$ & $-0,471^{*}$ & $0,253^{* * *}$ & $-0,255^{* * *}$ & $-0,486 * * *$ \\
\hline MB04 & $-0,805^{* * *}$ & $-0,552^{* * *}$ & $-0,026$ & $-0,139 * *$ & $-0,022$ \\
\hline \multicolumn{6}{|l|}{ Economie (ref.) } \\
\hline Gedrag en Maatschappij & $-0,154$ & 0,091 & $-0,799 * * *$ & $-0,803 * * *$ & $-0,086$ \\
\hline Landbouw & 0,063 & 0,224 & $-0,018$ & $-0,150 * *$ & $-0,306^{* * *}$ \\
\hline Techniek & $-0,043$ & 0,239 & $-0,054$ & $-0,262^{* * *}$ & $-0,052$ \\
\hline Zorg & $-0,738 * * *$ & $-0,405^{*}$ & $-0,805^{* * *}$ & $-1,044^{* * *}$ & $-0,291^{* * *}$ \\
\hline \multicolumn{6}{|l|}{ Persoonlijke achtergrond } \\
\hline Man (vrouwen zijn ref.) & $-0,344^{* * *}$ & $-0,036$ & $-0,051$ & $-0,189 * * *$ & $0,166^{* * *}$ \\
\hline \multicolumn{6}{|l|}{ Autochtonen (ref.) } \\
\hline Niet westerse allochtonen & $0,781^{* * *}$ & $1,031^{* * *}$ & $-0,262 * * *$ & $-0,149 * *$ & $0,364 * * *$ \\
\hline Westerse allochtonen & $0,582 * * *$ & $0,838 * * *$ & $-0,101$ & $-0,110$ & 0,008 \\
\hline Leeftijd (gecentreerd) & $0,020 * * *$ & $0,027 * *$ & 0,003 & 0,003 & $-0,087^{* * *}$ \\
\hline \multicolumn{6}{|l|}{ Westen (ref.) } \\
\hline Noorden & $0,622 * * *$ & $0,681 * * *$ & $-0,007$ & 0,026 & $0,188^{* * *}$ \\
\hline Oosten & 0,061 & $-0,245$ & $-0,004$ & 0,010 & $0,111 * *$ \\
\hline Zuiden & 0,035 & $-0,365$ & $0,136^{* *}$ & 0,078 & $0,115^{* *}$ \\
\hline \multicolumn{6}{|l|}{ Gemiddeld eindcijfer (ref.) } \\
\hline Bovengemiddeld eindcijfer & $-0,088$ & 0,067 & $-0,092^{*}$ & 0,017 & $0,204^{* * *}$ \\
\hline Ondergemiddeld eindcijfer & $0,297 * *$ & 0,206 & $0,290 * *$ & $0,219 * * *$ & 0,076 \\
\hline \multicolumn{6}{|l|}{ Geen twee-oudergezin (ref.) } \\
\hline twee-oudergezin & $-0,176^{*}$ & $-0,408^{* *}$ & $0,172^{* * *}$ & $0,084^{*}$ & $0,243^{* * *}$ \\
\hline \multicolumn{6}{|l|}{ vader middelbaar opgeleid (ref.) } \\
\hline vader laag opgeleid & $0,316^{* * *}$ & $0,476^{* *}$ & 0,023 & $-0,088^{*}$ & $-0,145^{* * *}$ \\
\hline vader hoog opgeleid & $0,386^{* * *}$ & $0,645^{* * *}$ & $-0,149 * *$ & $-0,083$ & $0,111 * *$ \\
\hline Constante & $-3,471^{* * *}$ & $-5,612 * * *$ & $-1,063 * * *$ & $-0,885^{* * *}$ & $-0,744^{* * *}$ \\
\hline
\end{tabular}

Noot: ${ }^{*} p<.05{ }^{* *} p<.01{ }^{* * *} p<.001$

Bron: SIS (ROA), 2009-2012 


\section{Tabel B 2.10}

Logitanalyse op arbeidsmarktprestaties van MBO-gediplomeerden, behorende bij tabel 2.10 van hoofdstuk 2

\begin{tabular}{|c|c|c|c|}
\hline & Werkloos & Overeducatie & Horizontale mismatch \\
\hline \multicolumn{4}{|l|}{ Opleiding } \\
\hline \multicolumn{4}{|l|}{ BBL (ref.) } \\
\hline $\mathrm{BOL}$ & $0,829^{* * *}$ & $-0,202^{* * *}$ & $0,262^{* * *}$ \\
\hline \multicolumn{4}{|l|}{ MBO2 (ref.) } \\
\hline MB03 & $-0,423^{* * *}$ & $0,251^{* * *}$ & $-0,262^{* * *}$ \\
\hline MB04 & $-0,809^{* * *}$ & $-0,025$ & $-0,139 * *$ \\
\hline \multicolumn{4}{|l|}{ Economie (ref.) } \\
\hline Gedrag en Maatschappij & $-0,157$ & $-0,803^{* * *}$ & $-0,810^{* * *}$ \\
\hline Landbouw & 0,036 & $-0,028$ & $-0,166^{* *}$ \\
\hline Techniek & $-0,057$ & $-0,058$ & $-0,272^{* * *}$ \\
\hline Zorg & $-0,732^{* * *}$ & $-0,798^{* * *}$ & $-1,039^{* * *}$ \\
\hline \multicolumn{4}{|l|}{ Persoonlijke achtergrond } \\
\hline Man (vrouwen zijn ref.) & $-0,347^{* * *}$ & $-0,052$ & $-0,191^{* * *}$ \\
\hline \multicolumn{4}{|l|}{ Autochtonen (ref.) } \\
\hline Niet westerse allochtonen & $0,777^{* * *}$ & $-0,269 * * *$ & $-0,162^{* *}$ \\
\hline Westerse allochtonen & $0,578^{* * *}$ & $-0,105$ & $-0,116$ \\
\hline Leeftijd (gecentreerd) & $0,020^{* * *}$ & 0,003 & 0,003 \\
\hline \multicolumn{4}{|l|}{ Westen (ref.) } \\
\hline Noorden & $0,613^{* * *}$ & $-0,012$ & 0,017 \\
\hline Oosten & 0,050 & $-0,009$ & 0,002 \\
\hline Zuiden & 0,035 & $0,136^{* *}$ & 0,078 \\
\hline \multicolumn{4}{|l|}{ Gemiddeld eindcijfer (ref.) } \\
\hline Bovengemiddeld eindcijfer & $-0,095$ & $-0,095^{*}$ & 0,012 \\
\hline Ondergemiddeld eindcijfer & $0,282^{* *}$ & $0,282^{* * *}$ & $0,205^{* * *}$ \\
\hline \multicolumn{4}{|l|}{ Geen twee-oudergezin (ref.) } \\
\hline Twee-ouder gezin & $-0,185^{*}$ & $0,167^{* * *}$ & $0,076^{*}$ \\
\hline \multicolumn{4}{|l|}{ Vader middelbaar opgeleid } \\
\hline Vader laag opgeleid & $0,315^{* * *}$ & 0,023 & $-0,089^{*}$ \\
\hline Vader hoog opgeleid & $0,378^{* * *}$ & $-0,154^{* *}$ & $-0,090$ \\
\hline Opleiding te theoriegericht (niet=ref.) & 0,131 & 0,093 & $0,170^{* *}$ \\
\hline Opleiding te praktijkgericht (niet=ref.) & 0,018 & 0,130 & $0,206^{* *}$ \\
\hline Opleiding te smal (niet=ref.) & $0,507^{* * *}$ & $0,274^{* * *}$ & $0,382^{* * * *}$ \\
\hline Opleiding te breed (niet=ref.) & 0,003 & 0,102 & $-0,110$ \\
\hline Constante & $-3,497^{* * *}$ & $-1,079^{* * *}$ & $-0,911^{* * *}$ \\
\hline
\end{tabular}

Noot: ${ }^{*} p<.05^{* *} p<.01{ }^{* * *} p<.001$

Bron: SIS (ROA), 2009-2012 


\section{Bijlage 2: Tabellen hoofdstuk 3}

\section{Tabel B3.3}

Resultaten van regressieanalyse, afhankelijke variabele verandering in succesmaat ná aanvang van de crisis ten opzichte van de situatie vóór de crisis

\begin{tabular}{|l|l|l|l|l|}
\hline & Kans op werk & Uurloon & Werkzekerheid & Kerndomein \\
\hline Constante & $21.595^{*}$ & 4.105 & $-31.074^{*}$ & -23.589 \\
\hline Opleidingssector (ref. HE0) & & & & \\
\hline HAO & -0.525 & 0.055 & 3.917 & 0.955 \\
\hline HPO & -0.776 & 0.401 & 0.537 & $5.435^{*}$ \\
\hline HTO & -0.726 & 0.127 & -2.556 & 1.271 \\
\hline HGZO & $4.288^{* * *}$ & $1.586^{* * *}$ & $7.797^{* * *}$ & 2.566 \\
\hline HSAO & $1.656^{* *}$ & $0.896^{* * *}$ & 0.134 & $-2.987^{*}$ \\
\hline KUO & -0.729 & -0.452 & -3.961 & -6.741 \\
\hline \% vrouwen & $-0.036^{* * *}$ & $-0.013^{* * *}$ & $-0.061^{* *}$ & -0.031 \\
\hline \% niet-westerse allochtonen & $-0.082^{*}$ & 0.024 & -0.046 & -0.161 \\
\hline Balansvragen: & & & & \\
\hline moeilijkheidsgraad & $-3.952^{*}$ & $-1.526^{*}$ & $-12.887^{* *}$ & 0.812 \\
\hline verhouding theorie-praktijk & $-4.269^{* * *}$ & -0.188 & 2.677 & 2.373 \\
\hline Selectiviteit & $6.839^{*}$ & $3.460^{* *}$ & $29.609^{* * *}$ & 5.837 \\
\hline Rapportcijfers: & & & & -0.084 \\
\hline aansluiting actuele ontwikkelingen & -1.969 & $-0.788^{*}$ & $-8.139^{* *}$ & -3.530 \\
\hline Voorbereiding op beroepspraktijk & $7.109^{* * *}$ & $1.640^{* * *}$ & $5.534^{*}$ & 4.376 \\
\hline Docenten (3 items) & 1.117 & $-0.814^{*}$ & 0.402 & -0.716 \\
\hline Stand op succesindicator vóór de crisis & $-.540^{* * *}$ & $-0.537^{* * *}$ & $-0.150^{* * *}$ & - \\
\hline *** significant op 1\% niveau & & & & \\
\hline ** significant op 5\% niveau & & & & \\
\hline significant op 10\% niveau & & & & \\
\hline
\end{tabular}




\section{Tabel B3.4a}

Resultaten van logistische regressieanalyse, afhankelijke variabele kans op werk

\begin{tabular}{|c|c|c|}
\hline & $\begin{array}{l}\text { Hoofdeffect } \\
\text { B }\end{array}$ & $\begin{array}{c}\text { Interactie met verandering } \\
\text { voor-na begin crisis } \\
\text { B }\end{array}$ \\
\hline \multicolumn{3}{|l|}{ HBO-sector (ref. HEO) } \\
\hline$H A O$ & 0.064 & nvt \\
\hline HPO & $-0.260 * * *$ & nvt \\
\hline HTO & $0.382^{* * *}$ & nvt \\
\hline HGZO & $0.421^{* * *}$ & nvt \\
\hline HSAO & -0.100 & nvt \\
\hline KUO & -0.208 & nvt \\
\hline Geslacht: vrouw & -0.094 & -0.026 \\
\hline Leeftijd & $-0.073 * * *$ & 0.008 \\
\hline \multicolumn{3}{|l|}{ Etniciteit (ref. autochtoon) } \\
\hline westerse allochtoon & -0.066 & 0.076 \\
\hline niet-westerse allochtoon & $-0.825^{* * *}$ & 0.114 \\
\hline \multicolumn{3}{|l|}{ Hoogst voltooide vooropleiding (ref. VW0) } \\
\hline HAVO & -0.089 & -0.018 \\
\hline MBO & 0.127 & -0.021 \\
\hline anders & 0.116 & 0.050 \\
\hline Gemiddeld eindcijfer & $0.252^{* * *}$ & 0.033 \\
\hline \multicolumn{3}{|l|}{ Ervaring tijdens $\mathrm{HBO}$ opleiding } \\
\hline stage in buitenland & -0.046 & 0.033 \\
\hline rel. werkervaring (behalve stage) & $0.188^{* * *}$ & 0.047 \\
\hline buitenlands studieonderdeel & -0.150 & -0.138 \\
\hline bestuurlijke ervaring & $0.137^{*}$ & -0.036 \\
\hline $\mathrm{Na}-/$ bijscholing gevolgd & $0.970^{* * *}$ & $0.122 * *$ \\
\hline \multicolumn{3}{|l|}{ Regio opleiding (ref. west): } \\
\hline noord & -0.132 & -0.014 \\
\hline oost & -0.079 & 0.068 \\
\hline zuid & -0.089 & $-0.135^{*}$ \\
\hline Verandering kans op werk na begin crisis & -0.089 & nvt \\
\hline Constante & $2.463^{* * *}$ & \\
\hline $\begin{array}{l}\text { *** } \text { significant op } 1 \% \text { niveau } \\
\text { ** } \text { significant op } 5 \% \text { niveau } \\
\text { * } \quad \text { significant op } 10 \% \text { niveau }\end{array}$ & & \\
\hline
\end{tabular}


Tabel B3.4b

Resultaten van regressieanalyse, afhankelijke variabele uurloon

\begin{tabular}{|c|c|c|}
\hline & $\begin{array}{l}\text { Hoofdeffect } \\
\text { B }\end{array}$ & $\begin{array}{l}\text { Interactie met verandering } \\
\text { voor-na begin crisis } \\
\text { B }\end{array}$ \\
\hline \multicolumn{3}{|l|}{ HBO-sector (ref. HEO) } \\
\hline HAO & 0.025 & nvt \\
\hline HPO & $0.284^{*}$ & nvt \\
\hline HTO & $0.296^{* *}$ & nvt \\
\hline HGZO & $1.920^{* * *}$ & nvt \\
\hline HSAO & $0.647^{* * *}$ & nvt \\
\hline KUO & $1.672^{* *}$ & nvt \\
\hline Geslacht: vrouw & $-0.975^{* * *}$ & -0.065 \\
\hline Leeftijd & $0.233^{* * *}$ & $0.038^{* *}$ \\
\hline \multicolumn{3}{|l|}{ Etniciteit (ref. autochtoon) } \\
\hline westerse allochtoon & -0.043 & $-0.382^{*}$ \\
\hline niet-westerse allochtoon & -0.079 & 0.072 \\
\hline \multicolumn{3}{|c|}{ Hoogst voltooide vooropleiding (ref. VW0) } \\
\hline HAVO & 0.063 & -0.154 \\
\hline$M B O$ & 0.069 & -0.171 \\
\hline anders & -0.181 & 0.082 \\
\hline Gemiddeld eindcijfer & $0.320^{* * *}$ & $-0.305^{* * *}$ \\
\hline \multicolumn{3}{|l|}{ Ervaring tijdens $\mathrm{HBO}$ opleiding } \\
\hline stage in buitenland & -0.101 & 0.096 \\
\hline rel. werkervaring (behalve stage) & $0.269 * * *$ & -0.104 \\
\hline buitenlands studieonderdeel & 0.044 & -0.271 \\
\hline bestuurlijke ervaring & $0.292 * *$ & -0.017 \\
\hline $\mathrm{Na}-/$ bijscholing gevolgd & $0.768^{* * *}$ & -0.135 \\
\hline \multicolumn{3}{|l|}{ Regio opleiding (ref. west): } \\
\hline noord & $-0.767 * * *$ & -0.183 \\
\hline oost & $-0.408^{* * *}$ & -0.184 \\
\hline zuid & $-0.386 * * *$ & 0.009 \\
\hline \multicolumn{3}{|l|}{ Bedrijfsgrootte } \\
\hline klein & 0.169 & $0.423^{* * *}$ \\
\hline groot & $0.309 * * *$ & $-0.215^{*}$ \\
\hline Verandering uurloon na begin crisis & $1.875^{* *}$ & nvt \\
\hline Constante & $5.404 * * *$ & \\
\hline $\begin{array}{l}\text { *** } \text { significant op } 1 \% \text { niveau } \\
\text { ** } \quad \text { significant op } 5 \% \text { niveau } \\
\text { * } \quad \text { significant op } 10 \% \text { niveau }\end{array}$ & & \\
\hline
\end{tabular}




\section{Tabel B3.4c}

Resultaten van logistische regressieanalyse, afhankelijke variabele werkzekerheid

\begin{tabular}{|c|c|c|}
\hline & $\begin{array}{l}\text { Hoofdeffect } \\
\text { B }\end{array}$ & $\begin{array}{c}\text { Interactie met verandering } \\
\text { voor-na begin crisis } \\
\text { B }\end{array}$ \\
\hline \multicolumn{3}{|l|}{ HBO-sector (ref. HE0) } \\
\hline HAO & $-0.209 * *$ & nvt \\
\hline HPO & $-0.173 * * *$ & nvt \\
\hline HTO & $0.148^{* * *}$ & nvt \\
\hline HGZO & $0.433^{* * *}$ & nvt \\
\hline HSAO & 0.028 & nvt \\
\hline KUO & $0.771^{* * *}$ & nvt \\
\hline Geslacht: vrouw & $-0.400 * * *$ & $-0.141^{* * *}$ \\
\hline Leeftijd & $0.028 * * *$ & $-0.010^{*}$ \\
\hline \multicolumn{3}{|l|}{ Etniciteit (ref. autochtoon) } \\
\hline westerse allochtoon & $0.195^{* * *}$ & 0.006 \\
\hline niet-westerse allochtoon & $-0.179 * * *$ & 0.047 \\
\hline \multicolumn{3}{|l|}{ Hoogst voltooide vooropleiding (ref. VW0) } \\
\hline HAVO & -0.020 & 0.061 \\
\hline MBO & 0.007 & 0.018 \\
\hline anders & -0.109 & 0.022 \\
\hline Gemiddeld eindcijfer & $0.142 * * *$ & 0.031 \\
\hline \multicolumn{3}{|l|}{ Ervaring tijdens $\mathrm{HBO}$ opleiding } \\
\hline stage in buitenland & $0.150 * * *$ & $0.103^{* * *}$ \\
\hline rel. werkervaring (behalve stage) & $0.096^{* * *}$ & 0.031 \\
\hline buitenlands studieonderdeel & 0.053 & -0.039 \\
\hline bestuurlijke ervaring & 0.044 & $0.102^{* * *}$ \\
\hline $\mathrm{Na}$-/bijscholing gevolgd & $0.370^{* * *}$ & $-0.092^{* * *}$ \\
\hline \multicolumn{3}{|l|}{ Regio opleiding (ref. west): } \\
\hline noord & $-0.371^{* * *}$ & $0.168^{* * *}$ \\
\hline oost & $-0.216^{* * *}$ & $0.113^{* * *}$ \\
\hline zuid & $-0.193^{* * *}$ & $0.105^{* * *}$ \\
\hline \multicolumn{3}{|l|}{ Bedrijfsgrootte } \\
\hline klein & 0.058 & $-0.087^{* *}$ \\
\hline groot & $-0.198 * * *$ & 0.025 \\
\hline Verandering werkzekerheid na begin crisis & 0.110 & nvt \\
\hline Constante & $-1.662^{* * *}$ & \\
\hline $\begin{array}{ll}* * * & \text { significant op } 1 \% \text { niveau } \\
* * & \text { significant op } 5 \% \text { niveau } \\
* & \text { significant op } 10 \% \text { niveau }\end{array}$ & & \\
\hline
\end{tabular}


Tabel B3.4d

Resultaten van logistische regressieanalyse, afhankelijke variabele kans op werk in kerndomein

\begin{tabular}{|c|c|c|}
\hline & $\begin{array}{l}\text { Hoofdeffect } \\
\text { B }\end{array}$ & $\begin{array}{l}\text { Interactie met verandering } \\
\text { voor-na begin crisis } \\
\text { B }\end{array}$ \\
\hline \multicolumn{3}{|l|}{ HBO-sector (ref. HEO) } \\
\hline HAO & -0.063 & nvt \\
\hline HPO & $1.549 * * *$ & nvt \\
\hline HTO & $0.840 * * *$ & nvt \\
\hline HGZO & $0.970 * * *$ & nvt \\
\hline HSAO & 0.028 & nvt \\
\hline KUO & $2.034^{* * *}$ & nvt \\
\hline Geslacht: vrouw & $-0.188^{* * *}$ & -0.011 \\
\hline Leeftijd & $-0.019 * * *$ & $-0.019 * * *$ \\
\hline \multicolumn{3}{|l|}{ Etniciteit (ref. autochtoon) } \\
\hline westerse allochtoon & -0.038 & $-0.124^{*}$ \\
\hline niet-westerse allochtoon & $-0.108^{*}$ & -0.063 \\
\hline \multicolumn{3}{|l|}{ Hoogst voltooide vooropleiding (ref. VW0) } \\
\hline HAVO & $-0.160 * * *$ & -0.013 \\
\hline$M B O$ & $-0.126^{* * *}$ & -0.004 \\
\hline anders & -0.013 & 0.059 \\
\hline Gemiddeld eindcijfer & $0.262 * * *$ & $-0.063 * *$ \\
\hline \multicolumn{3}{|l|}{ Ervaring tijdens $\mathrm{HBO}$ opleiding } \\
\hline stage in buitenland & $-0.102^{* * *}$ & $0.087^{*}$ \\
\hline rel. werkervaring (behalve stage) & $0.133^{* * *}$ & -0.007 \\
\hline buitenlands studieonderdeel & $0.111^{* *}$ & -0.097 \\
\hline bestuurlijke ervaring & 0.019 & -0.066 \\
\hline $\mathrm{Na}-/$ bijscholing gevolgd & $0.283 * * *$ & 0.051 \\
\hline \multicolumn{3}{|l|}{ Regio opleiding (ref. west): } \\
\hline noord & $-0.089 *$ & -0.071 \\
\hline oost & 0.028 & -0.015 \\
\hline zuid & 0.037 & -0.028 \\
\hline \multicolumn{3}{|l|}{ Bedrijfsgrootte } \\
\hline klein & -0.051 & $-0.174 * * *$ \\
\hline groot & $-0.140^{* * *}$ & -0.028 \\
\hline Verandering kans op werk in kerndomein na begin crisis & $1.264^{* * *}$ & nvt \\
\hline Constante & $-1.032^{* * *}$ & \\
\hline
\end{tabular}

*** significant op 1\% niveau

* significant op 5\% niveau

* significant op $10 \%$ niveau 



\section{Bijlage 3: Kernindicatoren}

Kernindicatoren 2012

\begin{tabular}{|c|c|c|c|c|c|c|c|c|c|}
\hline Opleidingssector & $\begin{array}{r}\text { aantal } \\
\text { respon- } \\
\text { denten }\end{array}$ & $\begin{array}{r}\text { verder } \\
\text { leren }\end{array}$ & $\begin{array}{r}\text { zelfde } \\
\text { opleiding } \\
\text { opnieuw } \\
\text { kiezen } \\
\%\end{array}$ & $\begin{array}{r}\text { werk- } \\
\text { loosheid }\end{array}$ & $\begin{array}{r}\text { intrede } \\
\text { werk- } \\
\text { loosheid } \\
\text { maanden }\end{array}$ & $\begin{array}{r}\text { flexibele } \\
\text { aanstelling }\end{array}$ & $\begin{array}{r}\text { bruto } \\
\text { uurloon }\end{array}$ & $\begin{array}{r}\text { minimaal } \\
\text { eigen } \\
\text { niveau } \\
\%\end{array}$ & $\begin{array}{r}\text { eigen/ } \\
\text { verwante } \\
\text { richting } \\
\%\end{array}$ \\
\hline HAVO/VWO & 1.149 & 87 & 97 & 27 & $\mathrm{x}$ & 75 & 5,58 & $\mathrm{x}$ & $x$ \\
\hline HAVO & 670 & 87 & 96 & 31 & $x$ & 80 & 4,97 & $\mathrm{x}$ & $\mathrm{x}$ \\
\hline VW0 & 479 & 88 & 98 & 20 & $x$ & 69 & 6,34 & $\mathrm{x}$ & $x$ \\
\hline VMBO & 1.951 & 98 & 87 & 15 & 0,9 & 65 & 4,46 & 82 & 61 \\
\hline Naarleerweg & & & & & & & & & \\
\hline Theoretisch & 699 & 98 & 87 & 24 & 0,7 & 70 & 4,33 & 62 & 38 \\
\hline Gemengd & 305 & 99 & 93 & 12 & 0,5 & 29 & 4,49 & 68 & 41 \\
\hline Kaderberoepsgericht & 551 & 98 & 89 & 15 & 1,2 & 65 & 4,04 & 86 & 70 \\
\hline $\begin{array}{l}\text { Basisberoepsgericht } \\
\text { Naar sector }\end{array}$ & 396 & 97 & 82 & 11 & 1,2 & 70 & 4,87 & 89 & 67 \\
\hline Landbouw & 540 & 98 & 85 & 11 & 0,9 & 60 & 4,98 & 86 & 63 \\
\hline Techniek & 166 & 99 & 88 & 7 & 0,8 & 67 & 5,00 & 94 & 77 \\
\hline Economie & 202 & 96 & 84 & 23 & 1,8 & 51 & 4,00 & 78 & 53 \\
\hline Gezondheidszorg & 261 & 97 & 90 & 11 & 0,8 & 73 & 4,14 & 85 & 60 \\
\hline Intersectoraal & 83 & 98 & 90 & 20 & 1,2 & 54 & 2,81 & 65 & 52 \\
\hline MBO & 5.166 & 43 & 80 & 8 & 0,9 & 40 & 10,73 & 71 & 75 \\
\hline $\mathrm{BOL}$ & 3.805 & 56 & 77 & 14 & 1,2 & 61 & 9,37 & 75 & 71 \\
\hline BOL niveau 1 & 119 & 74 & 80 & 30 & 3,2 & 79 & 7,22 & 81 & 67 \\
\hline BOL niveau 2 & 633 & 59 & 77 & 19 & 1,6 & 65 & 7,83 & 69 & 62 \\
\hline Landbouw & 66 & 66 & 72 & 21 & 2,0 & 82 & 5,70 & 73 & 71 \\
\hline Techniek & 132 & 55 & 83 & 17 & 2,2 & 67 & 8,05 & 67 & 66 \\
\hline Economie & 212 & 53 & 71 & 18 & 1,8 & 59 & 7,78 & 66 & 55 \\
\hline Gezondheidszorg & 223 & 66 & 79 & 21 & 0,9 & 69 & 7,87 & 76 & 66 \\
\hline
\end{tabular}


Kernindicatoren 2012

\begin{tabular}{|c|c|c|c|c|c|c|c|c|c|}
\hline Opleidingssector & $\begin{array}{r}\text { aantal } \\
\text { respon- } \\
\text { denten }\end{array}$ & $\begin{array}{r}\text { verder } \\
\text { leren } \\
\\
\%\end{array}$ & $\begin{array}{r}\text { zelfde } \\
\text { opleiding } \\
\text { opnieuw } \\
\text { kiezen } \\
\%\end{array}$ & $\begin{array}{r}\text { werk- } \\
\text { loosheid }\end{array}$ & $\begin{array}{r}\text { intrede } \\
\text { werk- } \\
\text { loosheid } \\
\text { maanden }\end{array}$ & $\begin{array}{r}\text { flexibele } \\
\text { aanstelling }\end{array}$ & $\begin{array}{r}\text { bruto } \\
\text { uurloon }\end{array}$ & $\begin{array}{r}\text { minimaal } \\
\text { eigen } \\
\text { niveau } \\
\%\end{array}$ & $\begin{array}{r}\text { eigen/ } \\
\text { verwante } \\
\text { richting } \\
\%\end{array}$ \\
\hline BOL niveau 3 & 797 & 45 & 76 & 15 & 1,2 & 58 & 9,21 & 70 & 73 \\
\hline Landbouw & 85 & 37 & 74 & 14 & 0,9 & 57 & 6,03 & 53 & 57 \\
\hline Techniek & 53 & 49 & 77 & 22 & 2,8 & 56 & 9,58 & 62 & 85 \\
\hline Economie & 268 & 55 & 70 & 19 & 1,5 & 62 & 8,60 & 65 & 62 \\
\hline Gezondheidszorg & 200 & 39 & 88 & 3 & 0,3 & 47 & 10,12 & 82 & 87 \\
\hline $\begin{array}{l}\text { Gedrag en } \\
\text { maatschappij }\end{array}$ & 191 & 34 & 73 & 19 & 1,1 & 67 & 9,74 & 72 & 70 \\
\hline BOL niveau 4 & 2.256 & 58 & 77 & 11 & 0,9 & 59 & 10,03 & 80 & 74 \\
\hline Landbouw & 197 & 50 & 73 & 16 & 0,9 & 57 & 9,08 & 72 & 64 \\
\hline Techniek & 467 & 56 & 77 & 6 & 0,8 & 52 & 10,06 & 79 & 73 \\
\hline Economie & 807 & 66 & 76 & 14 & 1,3 & 67 & 9,30 & 73 & 65 \\
\hline Gezondheidszorg & 385 & 43 & 81 & 6 & 0,5 & 54 & 11,13 & 90 & 89 \\
\hline $\begin{array}{l}\text { Gedrag en } \\
\text { maatschappij }\end{array}$ & 400 & 64 & 78 & 14 & 0,9 & 63 & 10,26 & 80 & 77 \\
\hline$B B L$ & 1.361 & 23 & 84 & 3 & 0,5 & 28 & 11,70 & 68 & 78 \\
\hline BBL niveau 1 & 173 & 20 & 83 & 5 & 1,5 & 17 & 10,91 & 44 & 46 \\
\hline BBL niveau 2 & 427 & 29 & 85 & 4 & 0,4 & 33 & 10,56 & 69 & 73 \\
\hline Landbouw & 61 & 32 & 86 & 7 & 0,2 & 28 & 9,51 & 57 & 64 \\
\hline Techniek & 221 & 32 & 87 & 2 & 0,3 & 35 & 10,67 & 67 & 73 \\
\hline Economie & 76 & 23 & 79 & 11 & 0,5 & 32 & 10,04 & 58 & 65 \\
\hline Gezondheidszorg & 69 & 25 & 82 & 3 & 0,5 & 26 & 11,22 & 93 & 84 \\
\hline BBL niveau 3 & 436 & 18 & 84 & 2 & 0,6 & 31 & 12,10 & 67 & 85 \\
\hline Landbouw & 53 & 18 & 80 & 2 & 0,4 & 15 & 12,31 & 52 & 76 \\
\hline Techniek & 105 & 26 & 85 & 0 & 0,7 & 34 & 12,55 & 63 & 86 \\
\hline Economie & 105 & 22 & 78 & 7 & 0,4 & 40 & 9,65 & 66 & 80 \\
\hline Gezondheidszorg & 114 & 7 & 89 & 1 & 0,7 & 24 & 13,28 & 71 & 92 \\
\hline $\begin{array}{l}\text { Gedrag en } \\
\text { maatschappij }\end{array}$ & 59 & 10 & 81 & 6 & 0,5 & 18 & 13,18 & 88 & 87 \\
\hline
\end{tabular}


Kernindicatoren 2012

\begin{tabular}{|c|c|c|c|c|c|c|c|c|c|}
\hline Opleidingssector & $\begin{array}{r}\text { aantal } \\
\text { respon- } \\
\text { denten }\end{array}$ & $\begin{array}{r}\text { verder } \\
\text { leren }\end{array}$ & $\begin{array}{r}\text { zelfde } \\
\text { opleiding } \\
\text { opnieuw } \\
\text { kiezen } \\
\%\end{array}$ & $\begin{array}{r}\text { werk- } \\
\text { loosheid }\end{array}$ & $\begin{array}{r}\text { intrede } \\
\text { werk- } \\
\text { loosheid } \\
\text { maanden }\end{array}$ & $\begin{array}{r}\text { flexibele } \\
\text { aanstelling }\end{array}$ & $\begin{array}{r}\text { bruto } \\
\text { uurloon }\end{array}$ & $\begin{array}{r}\text { minimaal } \\
\text { eigen } \\
\text { niveau } \\
\%\end{array}$ & $\begin{array}{r}\text { eigen/ } \\
\text { verwante } \\
\text { richting } \\
\%\end{array}$ \\
\hline BBL niveau 4 & 325 & 19 & 86 & 2 & 0,2 & 18 & 13,40 & 83 & 90 \\
\hline Landbouw & 16 & - & - & - & - & - & - & - & - \\
\hline Techniek & 61 & 27 & 92 & 0 & 0,0 & 5 & 14,17 & 77 & 92 \\
\hline Economie & 82 & 26 & 82 & 5 & 0,1 & 24 & 11,57 & 69 & 87 \\
\hline Gezondheidszorg & 113 & 11 & 86 & 0 & 0,1 & 18 & 14,58 & 95 & 94 \\
\hline $\begin{array}{l}\text { Gedrag en } \\
\text { maatschappij }\end{array}$ & 53 & 14 & 82 & 4 & 0,9 & 27 & 13,67 & 88 & 88 \\
\hline HBO & 15.313 & 31 & 79 & 9 & 1,7 & 58 & 13,28 & 77 & 78 \\
\hline Landbouw & 496 & 27 & 74 & 11 & 2,0 & 61 & 13,16 & 72 & 72 \\
\hline Onderwijs & 1.740 & 30 & 86 & 8 & 1,7 & 65 & 13,60 & 90 & 92 \\
\hline Techniek & 2.543 & 28 & 85 & 8 & 1,5 & 49 & 14,13 & 87 & 85 \\
\hline Economie & 5.840 & 36 & 73 & 10 & 1,9 & 58 & 12,99 & 77 & 66 \\
\hline Gezondheidszorg & 1.689 & 25 & 86 & 4 & 0,8 & 51 & 15,10 & 80 & 91 \\
\hline $\begin{array}{l}\text { Gedrag en } \\
\text { maatschappij }\end{array}$ & 1.921 & 25 & 76 & 9 & 2,3 & 66 & 13,15 & 52 & 83 \\
\hline Taal en cultuur & 1.084 & 26 & 85 & 12 & 1,6 & 64 & 9,65 & 64 & 63 \\
\hline Totaal & 23.579 & 64 & 85 & 10 & 1,1 & 48 & 10,56 & 72 & 74 \\
\hline
\end{tabular}

Bron: ROA (SIS)

- = te weinig waarnemingen; $x=$ vraag niet opgenomen 
Kernindicatoren 2001-2012

\begin{tabular}{|c|c|c|c|c|c|c|c|c|c|c|c|c|c|}
\hline \multicolumn{14}{|c|}{ Verder leren } \\
\hline & & 2001 & 2002 & 2003 & 2004 & 2005 & 2006 & 2007 & 2008 & 2009 & 2010 & 2011 & 2012 \\
\hline AVO & $\%$ & 95 & 86 & 90 & 91 & 87 & 88 & 88 & 90 & 89 & 87 & 90 & 87 \\
\hline VMBO & $\%$ & 91 & 86 & 87 & 88 & 85 & 87 & 89 & 92 & 95 & 96 & 97 & 98 \\
\hline BOL 1 & $\%$ & 51 & 36 & 53 & 38 & 34 & 45 & 23 & 53 & 51 & 67 & 56 & 74 \\
\hline BOL 2 & $\%$ & 52 & 45 & 52 & 49 & 36 & 63 & 32 & 60 & 59 & 58 & 60 & 59 \\
\hline BOL 3 & $\%$ & 32 & 30 & 33 & 33 & 26 & 40 & 27 & 43 & 43 & 48 & 44 & 45 \\
\hline BOL 4 & $\%$ & 49 & 51 & 52 & 56 & 55 & 56 & 55 & 57 & 55 & 57 & 59 & 58 \\
\hline BBL 1 & $\%$ & - & - & - & - & - & - & 10 & 30 & 25 & 29 & 20 & 20 \\
\hline BBL 2 & $\%$ & - & - & - & - & - & - & 19 & 35 & 33 & 34 & 34 & 29 \\
\hline BBL 3 & $\%$ & - & - & - & - & - & - & 13 & 24 & 21 & 25 & 25 & 18 \\
\hline BBL 4 & $\%$ & - & - & - & - & - & - & 15 & 17 & 18 & 24 & 16 & 19 \\
\hline HBO & $\%$ & 26 & 27 & 33 & 32 & 32 & 32 & 35 & 36 & 36 & 36 & 33 & 31 \\
\hline wo & $\%$ & 27 & 27 & 29 & 31 & 30 & 30 & 32 & 35 & 31 & $X$ & $X$ & $X$ \\
\hline
\end{tabular}

$\%$ schoolverlaters dat direct is doorgestroomd naar een vervolgopleiding.

\begin{tabular}{|l|r|r|r|r|r|r|r|r|r|r|r|r|r|}
\hline Werkloosheid & 2001 & 2002 & 2003 & 2004 & 2005 & 2006 & 2007 & 2008 & 2009 & 2010 & 2011 & 2012 \\
\hline AV0 & $\%$ & 0 & 7 & 16 & 17 & 19 & 10 & 19 & 15 & 16 & 15 & 9 & 27 \\
\hline VMB0 & $\%$ & 8 & 4 & 9 & 6 & 12 & 6 & 6 & 9 & 6 & 8 & 12 & 15 \\
\hline BOL 1 & $\%$ & 11 & 23 & 20 & 31 & 30 & 22 & 10 & 16 & 30 & 25 & 35 & 30 \\
\hline BOL 2 & $\%$ & 7 & 5 & 15 & 23 & 17 & 11 & 8 & 8 & 12 & 14 & 17 & 19 \\
\hline BOL 3 & $\%$ & 1 & 4 & 5 & 13 & 9 & 7 & 4 & 5 & 11 & 5 & 10 & 15 \\
\hline BOL 4 & $\%$ & 2 & 4 & 4 & 10 & 7 & 6 & 3 & 3 & 6 & 6 & 7 & 11 \\
\hline BBL 1 & $\%$ & - & - & - & - & - & - & 5 & 1 & 9 & 7 & 8 & 5 \\
\hline BBL 2 & $\%$ & - & - & - & - & - & - & 3 & 1 & 3 & 5 & 5 & 4 \\
\hline BBL3 & $\%$ & - & - & - & - & - & - & 0 & 1 & 3 & 2 & 2 & 2 \\
\hline BBL 4 & $\%$ & - & - & - & - & - & - & 2 & 1 & 1 & 2 & 3 & 2 \\
\hline HBO & $\%$ & 3 & 4 & 6 & 6 & 5 & 5 & 3 & 4 & 6 & 6 & 7 & 9 \\
\hline W0 & $\%$ & 3 & 3 & 5 & 5 & 4 & 4 & 3 & 4 & 5 & $X$ & $X$ & $X$ \\
\end{tabular}

\begin{tabular}{|c|c|c|c|c|c|c|c|c|c|c|c|c|c|}
\hline \multicolumn{14}{|c|}{ Flexibele aanstelling } \\
\hline & & 2001 & 2002 & 2003 & 2004 & 2005 & 2006 & 2007 & 2008 & 2009 & 2010 & 2011 & 2012 \\
\hline AVO & $\%$ & 25 & 47 & 40 & 37 & 53 & 63 & 65 & 59 & 42 & 52 & 66 & 75 \\
\hline VMBO & $\%$ & 19 & 27 & 32 & 44 & 54 & 48 & 56 & 63 & 63 & 60 & 65 & 65 \\
\hline BOL 1 & $\%$ & 23 & 46 & 25 & 48 & 47 & 74 & 72 & 56 & 61 & 63 & 72 & 79 \\
\hline BOL 2 & $\%$ & 21 & 26 & 35 & 47 & 46 & 51 & 46 & 54 & 54 & 53 & 62 & 65 \\
\hline BOL 3 & $\%$ & 12 & 20 & 28 & 38 & 43 & 49 & 44 & 43 & 43 & 49 & 54 & 58 \\
\hline BOL 4 & $\%$ & 14 & 22 & 31 & 40 & 43 & 42 & 40 & 36 & 44 & 50 & 49 & 59 \\
\hline BBL 1 & $\%$ & - & - & - & - & - & - & 16 & 29 & 20 & 20 & 21 & 17 \\
\hline BBL 2 & $\%$ & - & - & - & - & - & - & 27 & 30 & 30 & 35 & 31 & 33 \\
\hline BBL 3 & $\%$ & - & - & - & - & - & - & 18 & 19 & 25 & 21 & 24 & 31 \\
\hline BBL 4 & $\%$ & - & - & - & - & - & - & 14 & 13 & 13 & 15 & 17 & 18 \\
\hline HBO & $\%$ & 12 & 13 & 37 & 41 & 44 & 44 & 39 & 38 & 46 & 51 & 54 & 58 \\
\hline wo & $\%$ & 9 & 11 & 50 & 52 & 52 & 51 & 46 & 50 & - & $x$ & $x$ & $X$ \\
\hline
\end{tabular}

Een flexibele aanstelling betreft een aanstelling als uitzendkracht, oproepkracht e.d. of een aanstelling in tijdelijke dienst. 
Kernindicatoren 2001-2012

\begin{tabular}{|l|r|r|r|r|r|r|r|r|r|r|r|r|r|}
\hline Bruto uurloon & & 2001 & 2002 & 2003 & 2004 & 2005 & 2006 & 2007 & 2008 & 2009 & 2010 & 2011 & 2012 \\
\hline AV0 & $€$ & 6.86 & 6.48 & 6.15 & 6.33 & 6.02 & 6.09 & 6.40 & 6.88 & 6.96 & 6.05 & 5.94 & 5.58 \\
\hline VMB0 & $€$ & 4.44 & 4.66 & 4.68 & 4.54 & 4.76 & 4.91 & 4.85 & 4.85 & 4.83 & 4.68 & 4.48 & 4.46 \\
\hline BOL 1 & $€$ & 6.51 & 7.06 & 5.64 & 6.41 & 6.69 & 5.55 & 7.85 & 6.48 & 6.57 & 5.96 & 6.72 & 7.22 \\
\hline BOL 2 & $€$ & 7.20 & 6.74 & 6.54 & 6.88 & 6.94 & 6.86 & 7.60 & 7.69 & 7.85 & 8.02 & 7.89 & 7.83 \\
\hline BOL 3 & $€$ & 7.81 & 7.87 & 8.24 & 7.97 & 7.99 & 8.64 & 9.45 & 9.33 & 10.04 & 9.77 & 9.57 & 9.21 \\
\hline BOL 4 & $€$ & 8.91 & 8.44 & 8.52 & 8.68 & 8.75 & 9.45 & 10.10 & 10.19 & 10.36 & 10.64 & 10.35 & 10.03 \\
\hline BBL 1 & $€$ & - & - & - & - & - & - & 9.00 & 9.25 & 9.28 & 9.10 & 10.13 & 10.91 \\
\hline BBL2 & $€$ & - & - & - & - & - & - & 9.80 & 9.90 & 10.12 & 10.30 & 10.50 & 10.56 \\
\hline BBL 3 & $€$ & - & - & - & - & - & - & 11.40 & 11.68 & 11.72 & 11.95 & 12.12 & 12.10 \\
\hline BBL 4 & $€$ & - & - & - & - & - & - & 12.65 & 12.81 & 13.13 & 13.70 & 13.72 & 13.40 \\
\hline HBO & $€$ & 11.59 & 11.90 & 12.05 & 11.70 & 11.74 & 12.68 & 13.10 & 13.79 & 13.36 & 13.53 & 13.38 & 13.28 \\
\hline W0 & $€$ & 13.29 & 13.83 & 14.06 & 14.14 & 14.39 & 14.76 & 15.60 & 15.84 & 15.76 & $X$ & $X$ & $X$ \\
\hline
\end{tabular}

Het bruto uurloon heeft betrekking op de hoofdfunctie, en is inclusief toeslagen maar exclusief inkomen uit overwerk.

\begin{tabular}{|l|r|r|r|r|r|r|r|r|r|r|r|r|r|}
\multicolumn{6}{|c|}{ Minimaal eigen niveau } \\
\hline AV0 & $\%$ & 2001 & 2002 & 2003 & 2004 & 2005 & 2006 & 2007 & 2008 & 2009 & 2010 & 2011 & 2012 \\
\hline VMB0 & $\%$ & - & - & - & - & - & - & - & - & - & - & - & - \\
\hline BOL 1 & $\%$ & 79 & 84 & 87 & 87 & 87 & 87 & 60 & 88 & 86 & 92 & 76 & 82 \\
\hline BOL 2 & $\%$ & 30 & 32 & 52 & 44 & 29 & 68 & 60 & 59 & 57 & 79 & 74 & 81 \\
\hline BOL 3 & $\%$ & 49 & 64 & 68 & 63 & 61 & 63 & 64 & 73 & 68 & 74 & 71 & 69 \\
\hline BOL 4 & $\%$ & 64 & 65 & 75 & 65 & 64 & 77 & 79 & 84 & 76 & 77 & 76 & 70 \\
\hline BBL 1 & $\%$ & 73 & 71 & 70 & 76 & 79 & 83 & 84 & 86 & 85 & 87 & 82 & 80 \\
\hline BBL 2 & $\%$ & - & - & - & - & - & - & 46 & 51 & 51 & 44 & 40 & 44 \\
\hline BBL 3 & $\%$ & - & - & - & - & - & - & 64 & 71 & 62 & 69 & 65 & 69 \\
\hline BBL 4 & $\%$ & - & - & - & - & - & - & 87 & 82 & 82 & 84 & 87 & 83 \\
\hline HBO & $\%$ & 79 & 77 & 76 & 75 & 77 & 82 & 85 & 84 & 82 & 80 & 78 & 77 \\
\hline W0 & $\%$ & 66 & 66 & 64 & 63 & 61 & 65 & 64 & 67 & 67 & X & X & X \\
\hline
\end{tabular}

Het minimaal eigen niveau betreft het opleidingsniveau dat door de werkgever voor deze functie minimaal vereist is.

\begin{tabular}{|l|r|r|r|r|r|r|r|r|r|r|r|r|r|}
\hline \multicolumn{2}{|l|}{ Eigen/verwante richting } & 2001 & 2002 & 2003 & 2004 & 2005 & 2006 & 2007 & 2008 & 2009 & 2010 & 2011 & 2012 \\
\hline AV0 & $\%$ & - & - & - & - & - & - & - & - & - & - & - & - \\
\hline VMB0 & $\%$ & 53 & 62 & 62 & 64 & 58 & 62 & 48 & 57 & 51 & 65 & 63 & 61 \\
\hline BOL 1 & $\%$ & 37 & 46 & 38 & 56 & 49 & 51 & 37 & 53 & 54 & 77 & 59 & 67 \\
\hline BOL 2 & $\%$ & 57 & 62 & 58 & 64 & 53 & 57 & 50 & 56 & 58 & 59 & 61 & 62 \\
\hline BOL 3 & $\%$ & 76 & 71 & 78 & 70 & 67 & 74 & 73 & 76 & 76 & 78 & 75 & 73 \\
\hline BOL 4 & $\%$ & 70 & 73 & 70 & 69 & 72 & 77 & 76 & 74 & 76 & 76 & 80 & 74 \\
\hline BBL 1 & $\%$ & - & - & - & - & - & - & 52 & 52 & 41 & 51 & 58 & 46 \\
\hline BBL 2 & $\%$ & - & - & - & - & - & - & 65 & 62 & 61 & 64 & 74 & 73 \\
\hline BBL3 & $\%$ & - & - & - & - & - & - & 79 & 77 & 78 & 79 & 84 & 85 \\
\hline BBL 4 & $\%$ & - & - & - & - & - & - & 84 & 81 & 83 & 83 & 87 & 90 \\
\hline HBO & $\%$ & 76 & 78 & 79 & 78 & 76 & 80 & 82 & 82 & 80 & 79 & 78 & 78 \\
\hline W0 & $\%$ & 71 & 73 & 71 & 72 & 70 & 74 & 74 & 71 & 73 & $X$ & $X$ & X \\
\hline
\end{tabular}

De eigen/verwante richting betreft de opleidingsrichting dat door de werkgever voor deze functie minimaal vereist is. 
Kernindicatoren 2001-2012

Zelfde opleiding opnieuw kiezen

\begin{tabular}{|c|c|c|c|c|c|c|c|c|c|c|c|c|c|}
\hline & & 2001 & 2002 & 2003 & 2004 & 2005 & 2006 & 2007 & 2008 & 2009 & 2010 & 2011 & 2012 \\
\hline AVO & $\%$ & 81 & - & - & - & - & - & 96 & 97 & 96 & 95 & 97 & 97 \\
\hline VMBO & $\%$ & 80 & 76 & 86 & 84 & 85 & 88 & 84 & 81 & 82 & 84 & 88 & 87 \\
\hline BOL 1 & $\%$ & 69 & 68 & 55 & 60 & 63 & 66 & 61 & 67 & 68 & 72 & 75 & 80 \\
\hline BOL 2 & $\%$ & 63 & 64 & 73 & 62 & 60 & 67 & 64 & 69 & 73 & 75 & 74 & 77 \\
\hline BOL 3 & $\%$ & 77 & 72 & 79 & 76 & 71 & 74 & 75 & 76 & 77 & 79 & 76 & 76 \\
\hline BOL 4 & $\%$ & 79 & 78 & 82 & 77 & 78 & 77 & 80 & 78 & 79 & 79 & 79 & 77 \\
\hline BBL 1 & $\%$ & - & - & - & - & - & - & 61 & 64 & 87 & 75 & 78 & 83 \\
\hline BBL 2 & $\%$ & - & - & - & - & - & - & 74 & 77 & 84 & 81 & 82 & 85 \\
\hline BBL 3 & $\%$ & - & - & - & - & - & - & 81 & 84 & 83 & 85 & 88 & 84 \\
\hline BBL 4 & $\%$ & - & - & - & - & - & - & 80 & 82 & 84 & 83 & 85 & 86 \\
\hline HBO & $\%$ & 77 & 76 & 81 & 78 & 78 & 78 & 80 & 78 & 78 & 79 & 79 & 79 \\
\hline W0 & $\%$ & 80 & 80 & 83 & 81 & 81 & 82 & 83 & 83 & 86 & $X$ & $X$ & $X$ \\
\hline
\end{tabular}

$\%$ schoolverlaters dat achteraf bezien dezelfde opleiding opnieuw zal kiezen.

- niet gevraagd

* te weinig waarnemingen

$X$ voor 2010, 2011 en 2012 niet beschikbaar 
Statistische Bijlage

Tabellen naar opleidingssector 
Op de website Kerncijfers Schoolverlatersonderzoeken (www.roa.unimaas.nl/kerncijfers.htm) zijn landelijke statistieken te vinden over gediplomeerde schoolverlaters van het initiele onderwijs in Nederland. De cijfers zijn gebaseerd op de schoolverlatersonderzoeken van het ROA en hebben betrekking op de gediplomeerden van het AVO, $\mathrm{VMBO}, \mathrm{MBO}$ en het $\mathrm{HO}$. De kerncijfers die gepresenteerd worden geven een inzicht in de gevolgde studie, het vervolgonderwijs en de intrede van de schoolverlaters op de arbeidsmarkt.

De website is te raadplegen vanuit twee invalshoeken: naar onderwijsindeling en naar kernindicator. De invalshoek naar onderwijs laat alle kerncijfers voor een bepaalde onderwijsindeling zien. Hierbij kan gekozen worden voor onderwijsniveaus, onderwijssectoren en individuele opleidingen. Daarnaast is er de mogelijkheid om een keuze te maken voor voltijd, deeltijd of duale opleidingsvarianten. De invalshoek naar indicator laat voor alle onderwijsniveaus, - sectoren dan wel opleidingen de informatie over één gekozen indicator zien. Zowel in het menu als in de overzichtstabellen zijn de kernindicatoren naar een vijftal categorieën ingedeeld:

- algemene achtergrondkenmerken

- gevolgde opleiding

- oordeel over de gevolgde opleiding

- kenmerken vervolgonderwijs

- arbeidsmarktindicatoren en baankenmerken

De cijfers worden telkens weergegeven voor de laatste vijf meetjaren en worden jaarlijks geupdate rond de tijd dat het landelijk rapport 'Schoolverlaters tussen Onderwijs en Arbeidsmarkt' uitkomt. 


\section{Inhoud}

\section{Algemeen}

I Aantallen en respons

2 De uitstroom van schoolverlaters verbijzonderd naar geslacht, etniciteit en gemiddelde leeftijd op moment van enquête

\section{Oordeel over gevolgde opleiding}

$4 \quad$ Oordeel van gediplomeerde schoolverlaters: breedte en diepgang van gevolgde opleiding

$5 \quad$ Oordeel van gediplomeerde schoolverlaters: basis te starten op de arbeidsmarkt en basis om kennis en vaardigheden verder te ontwikkelen

6 Oordeel van gediplomeerde schoolverlaters: moeilijkheidsgraad van gevolgde opleiding

$7 \quad$ Oordeel van gediplomeerde schoolverlaters: strenge beoordeling van studenten

8 Oordeel van gediplomeerde schoolverlaters: uitdagend niveau

9 Oordeel van gediplomeerde schoolverlaters: pittige tentamens/opdrachten

IO Oordeel van gediplomeerde schoolverlaters: toetsen op inzicht

\section{Vervolgonderwijs}

II Doorstroom en type vervolgonderwijs

I2 Oordeel van schoolverlaters over de aansluiting van de afgelopen opleiding met de vervolgopleiding

I3 Uitvallers en studiewisselaars

\section{Arbeidsmarkt}

\section{I4 Werkloosheid}

I5 Werkloosheid tot eerste baan

I8 Percentage werkende schoolverlaters met een deeltijdaanstelling en wekelijkse arbeidsduur 
23 Beloning van werkende schoolverlaters

24 Tevredenheid met huidige functie

25 Percentage werkende schoolverlaters waarvan huidige functie goede carriereperspectieven biedt

26 Benutting van kennis en vaardigheden schieten tekort

Tevredenheid achteraf

28 Opleiding achteraf opnieuw kiezen 
Tabel 1

Aantallen en respons

\begin{tabular}{|c|c|c|c|c|}
\hline & benaderde aantallen & responspercentage & ongewogen aantallen & gewogen aantallen \\
\hline HAVO/VWO & 2.995 & 38 & 1.149 & 75.143 \\
\hline HAVO & 1.850 & 36 & 670 & 42.467 \\
\hline vwo & 1.145 & 42 & 479 & 32.676 \\
\hline VMBO & 7.264 & 27 & 1.951 & 88.734 \\
\hline \multicolumn{5}{|l|}{ Naar leerweg } \\
\hline Theoretisch & 2.405 & 29 & 699 & 36.909 \\
\hline Gemengd & 831 & 37 & 305 & 8.352 \\
\hline Kaderberoepsgericht & 2.133 & 26 & 551 & 24.511 \\
\hline Basisberoepsgericht & 1.886 & 21 & 396 & 18.963 \\
\hline \multicolumn{5}{|l|}{ Naar sector } \\
\hline Landbouw & 1.979 & 27 & 540 & 7.401 \\
\hline Techniek & 814 & 20 & 166 & 12.629 \\
\hline Economie & 835 & 24 & 202 & 12.669 \\
\hline Gezondheidszorg & 873 & 30 & 261 & 14.084 \\
\hline Intersectoraal & 358 & 23 & 83 & 5.042 \\
\hline MBO & 23.836 & 22 & 5.166 & 154.500 \\
\hline BOL & 16.464 & 23 & 3.805 & 91.667 \\
\hline BOL niveau 1 & 696 & 17 & 119 & 4.096 \\
\hline Landbouw & 28 & 18 & 5 & 92 \\
\hline Techniek & 85 & 16 & 14 & 527 \\
\hline Economie & 511 & 17 & 87 & 3.003 \\
\hline Gezondheidszorg & 72 & 18 & 13 & 473 \\
\hline BOL niveau 2 & 3.422 & 19 & 633 & 19.584 \\
\hline Landbouw & 282 & 24 & 66 & 984 \\
\hline Techniek & 806 & 17 & 132 & 4.813 \\
\hline Economie & 1.162 & 18 & 212 & 6.448 \\
\hline Gezondheidszorg & 1.172 & 19 & 223 & 7.339 \\
\hline BOL niveau 3 & 3.447 & 23 & 797 & 19.803 \\
\hline Landbouw & 360 & 24 & 85 & 1.249 \\
\hline Techniek & 295 & 18 & 53 & 1.605 \\
\hline Economie & 1.406 & 19 & 268 & 8.477 \\
\hline Gezondheidszorg & 679 & 29 & 200 & 4.165 \\
\hline Gedrag en maatschappij & 707 & 27 & 191 & 4.307 \\
\hline
\end{tabular}




\section{Tabel 1}

Aantallen en respons

\begin{tabular}{|c|c|c|c|c|}
\hline & benaderde aantallen & responspercentage & ongewogen aantallen & gewogen aantallen \\
\hline BOL niveau 4 & 8.899 & 25 & 2.256 & 48.183 \\
\hline Landbouw & 702 & 28 & 197 & 2.570 \\
\hline Techniek & 1.857 & 25 & 467 & 10.885 \\
\hline Economie & 3.583 & 23 & 807 & 17.951 \\
\hline Gezondheidszorg & 1.308 & 29 & 385 & 7.966 \\
\hline Gedrag en maatschappij & 1.449 & 28 & 400 & 8.812 \\
\hline BBL & 7.372 & 19 & 1.361 & 62.833 \\
\hline BBL niveau 1 & 1.039 & 17 & 173 & 7.076 \\
\hline Landbouw & 418 & 22 & 89 & 1.874 \\
\hline Techniek & 327 & 13 & 40 & 2.778 \\
\hline Economie & 266 & 17 & 44 & 2.423 \\
\hline BBL niveau 2 & 2.576 & 17 & 427 & 22.929 \\
\hline Landbouw & 390 & 16 & 61 & 1.661 \\
\hline Techniek & 1.391 & 16 & 221 & 13.999 \\
\hline Economie & 482 & 16 & 76 & 4.306 \\
\hline Gezondheidszorg & 313 & 22 & 69 & 2.962 \\
\hline BBL niveau 3 & 2.411 & 18 & 436 & 21.060 \\
\hline Landbouw & 282 & 19 & 53 & 1.151 \\
\hline Techniek & 824 & 13 & 105 & 8.017 \\
\hline Economie & 594 & 18 & 105 & 5.022 \\
\hline Gezondheidszorg & 488 & 23 & 114 & 4.883 \\
\hline Gedrag en maatschappij & 223 & 26 & 59 & 1.986 \\
\hline BBL niveau 4 & 1.346 & 24 & 325 & 11.769 \\
\hline Landbouw & 56 & 29 & 16 & 334 \\
\hline Techniek & 263 & 24 & 61 & 2.387 \\
\hline Economie & 455 & 18 & 82 & 3.731 \\
\hline Gezondheidszorg & 366 & 31 & 113 & 3.394 \\
\hline Gedrag en maatschappij & 206 & 26 & 53 & 1.922 \\
\hline
\end{tabular}


Tabel 1

Aantallen en respons

\begin{tabular}{|l|r|r|r|r|}
\hline & benaderde aantallen & responspercentage & ongewogen aantallen & gewogen aantallen \\
\hline HBO & & & & \\
\hline Landbouw & 41.418 & 38 & 15.313 & 49.090 \\
\hline Onderwijs & 1.211 & 42 & 496 & 1.259 \\
Techniek & 4.504 & 40 & 1.740 & 6.097 \\
Economie & 6.465 & 41 & 2.543 & 7.801 \\
Gezondheidszorg & 16.564 & 36 & 5.840 & 18.503 \\
Gedrag en maatschappij & 3.965 & 44 & 1.689 & 5.510 \\
\hline Taal en cultuur & 4.723 & 42 & 1.921 & 5.999 \\
& 3.986 & 30 & 1.084 & 3.921 \\
\hline Totaal & & & & 367.467 \\
\hline
\end{tabular}

Bron: ROA (SIS) 


\section{Tabel 2}

De uitstroom van schoolverlaters verbijzonderd naar geslacht, etniciteit en gemiddelde leeftijd op moment van enquête

\begin{tabular}{|c|c|c|c|c|c|}
\hline Opleidingssector & $\begin{array}{r}\text { vrouw } \\
\%\end{array}$ & $\begin{array}{l}\text { westerse allochtoon } \\
\qquad \%\end{array}$ & $\begin{array}{r}\text { niet-westerse } \\
\text { allochtoon } \\
\%\end{array}$ & $\begin{array}{r}\text { autochtoon } \\
\%\end{array}$ & $\begin{array}{c}\text { leeftijd } \\
\text { gem. }\end{array}$ \\
\hline HAVO/VWO & 53 & 5 & 7 & 87 & 18,9 \\
\hline HAVO & 52 & 5 & 8 & 87 & 18,6 \\
\hline vwo & 54 & 5 & 7 & 88 & 19,1 \\
\hline VMBO & 48 & 5 & 12 & 84 & 17,5 \\
\hline \multicolumn{6}{|l|}{ Naar leerweg } \\
\hline Theoretisch & 49 & 5 & 9 & 85 & 17,4 \\
\hline Gemengd & 51 & 4 & 5 & 91 & 17,4 \\
\hline Kaderberoepsgericht & 48 & 4 & 13 & 83 & 17,6 \\
\hline Basisberoepsgericht & 43 & 4 & 17 & 79 & 17,6 \\
\hline \multicolumn{6}{|l|}{ Naar sector } \\
\hline Landbouw & 53 & 4 & 2 & 95 & 17,5 \\
\hline Techniek & 2 & 1 & 8 & 91 & 17,6 \\
\hline Economie & 44 & 7 & 26 & 68 & 17,5 \\
\hline Gezondheidszorg & 89 & 5 & 12 & 84 & 17,5 \\
\hline Intersectoraal & 37 & 5 & 16 & 79 & 18,0 \\
\hline MBO & 49 & 5 & 12 & 83 & 26,5 \\
\hline $\mathrm{BOL}$ & 56 & 5 & 15 & 80 & 22,0 \\
\hline BOL niveau 1 & 47 & 5 & 45 & 50 & 22,9 \\
\hline BOL niveau 2 & 56 & 5 & 24 & 71 & 21,7 \\
\hline Landbouw & 55 & 6 & 1 & 92 & 20,0 \\
\hline Techniek & 12 & 6 & 27 & 68 & 22,5 \\
\hline Economie & 52 & 5 & 25 & 69 & 20,9 \\
\hline Gezondheidszorg & 88 & 4 & 25 & 71 & 22,1 \\
\hline BOL niveau 3 & 60 & 4 & 12 & 84 & 22,2 \\
\hline Landbouw & 57 & 1 & 4 & 95 & 21,1 \\
\hline Techniek & 16 & 1 & 15 & 84 & 23,6 \\
\hline Economie & 40 & 4 & 19 & 77 & 21,2 \\
\hline Gezondheidszorg & 84 & 6 & 4 & 90 & 23,0 \\
\hline Gedrag en maatschappij & 94 & 4 & 9 & 88 & 23,2 \\
\hline
\end{tabular}


Tabel 2

De uitstroom van schoolverlaters verbijzonderd naar geslacht, etniciteit en gemiddelde leeftijd op moment van enquête

\begin{tabular}{|c|c|c|c|c|c|}
\hline Opleidingssector & $\begin{array}{r}\text { vrouw } \\
\%\end{array}$ & $\begin{array}{l}\text { westerse allochtoon } \\
\%\end{array}$ & $\begin{array}{r}\text { niet-westerse } \\
\text { allochtoon } \\
\%\end{array}$ & $\begin{array}{r}\text { autochtoon } \\
\%\end{array}$ & $\begin{array}{r}\text { leeftijd } \\
\text { gem. }\end{array}$ \\
\hline BOL niveau 4 & 55 & 4 & 10 & 85 & 22,0 \\
\hline Landbouw & 61 & 1 & 0 & 99 & 21,6 \\
\hline Techniek & 28 & 4 & 6 & 90 & 22,4 \\
\hline Economie & 46 & 6 & 17 & 76 & 21,6 \\
\hline Gezondheidszorg & 76 & 5 & 6 & 89 & 22,4 \\
\hline Gedrag en maatschappij & 85 & 2 & 8 & 90 & 22,3 \\
\hline BBL & 38 & 6 & 7 & 87 & 33,0 \\
\hline BBL niveau 1 & 28 & 6 & 16 & 78 & 40,0 \\
\hline BBL niveau 2 & 28 & 8 & 7 & 85 & 32,9 \\
\hline Landbouw & 25 & 7 & 5 & 89 & 32,8 \\
\hline Techniek & 7 & 8 & 6 & 86 & 32,4 \\
\hline Economie & 57 & 7 & 4 & 88 & 31,5 \\
\hline Gezondheidszorg & 91 & 6 & 16 & 78 & 37,3 \\
\hline BBL niveau 3 & 44 & 5 & 6 & 88 & 30,6 \\
\hline Landbouw & 23 & 0 & 4 & 96 & 33,6 \\
\hline Techniek & 3 & 3 & 8 & 89 & 26,7 \\
\hline Economie & 47 & 7 & 5 & 88 & 27,2 \\
\hline Gezondheidszorg & 95 & 9 & 6 & 85 & 37,0 \\
\hline Gedrag en maatschappij & 87 & 3 & 5 & 92 & 37,2 \\
\hline BBL niveau 4 & 52 & 4 & 4 & 92 & 33,4 \\
\hline Landbouw & - & - & - & - & - \\
\hline Techniek & 10 & 2 & 5 & 94 & 32,1 \\
\hline Economie & 44 & 5 & 3 & 91 & 31,7 \\
\hline Gezondheidszorg & 84 & 3 & 5 & 93 & 33,7 \\
\hline Gedrag en maatschappij & 68 & 6 & 4 & 90 & 37,6 \\
\hline
\end{tabular}




\section{Tabel 2}

De uitstroom van schoolverlaters verbijzonderd naar geslacht, etniciteit en gemiddelde leeftijd op moment van enquête

\begin{tabular}{|c|c|c|c|c|c|}
\hline Opleidingssector & $\begin{array}{r}\text { vrouw } \\
\%\end{array}$ & $\begin{array}{l}\text { westerse allochtoon } \\
\qquad \%\end{array}$ & $\begin{array}{r}\text { niet-westerse } \\
\text { allochtoon } \\
\%\end{array}$ & $\begin{array}{r}\text { autochtoon } \\
\%\end{array}$ & $\begin{array}{r}\text { leeftijd } \\
\text { gem. }\end{array}$ \\
\hline HBO & 58 & 9 & 7 & 84 & 25,0 \\
\hline Landbouw & 46 & 5 & 2 & 93 & 24,8 \\
\hline Onderwijs & 76 & 4 & 3 & 93 & 25,5 \\
\hline Techniek & 16 & 6 & 6 & 88 & 24,7 \\
\hline Economie & 52 & 10 & 10 & 79 & 24,7 \\
\hline Gezondheidszorg & 82 & 9 & 4 & 87 & 24,8 \\
\hline Gedrag en maatschappij & 89 & 6 & 8 & 86 & 24,7 \\
\hline Taal en cultuur & 59 & 22 & 6 & 72 & 26,4 \\
\hline Totaal & 50 & 6 & 10 & 84 & 22,6 \\
\hline
\end{tabular}

\section{Toelichting}

Het betreft de leeftijd per onderzoeksdatum ongeveer anderhalf jaar na schoolverlaten. 
Tabel 3

Situatie op moment van enquête

\begin{tabular}{|c|c|c|c|c|}
\hline Opleidingssector & $\begin{array}{r}\text { studie } \\
\%\end{array}$ & $\begin{array}{r}\text { combinatie werken- } \\
\text { leren } \\
\%\end{array}$ & $\begin{array}{r}\text { betaald werk } \\
\qquad \%\end{array}$ & $\begin{array}{r}\text { anders } \\
\%\end{array}$ \\
\hline HAVO/VWO & 82 & 12 & 4 & 3 \\
\hline HAVO & 79 & 13 & 5 & 3 \\
\hline VW0 & 85 & 10 & 2 & 3 \\
\hline VMBO & 68 & 26 & 3 & 4 \\
\hline \multicolumn{5}{|l|}{ Naar leerweg } \\
\hline Theoretisch & 77 & 16 & 2 & 4 \\
\hline Gemengd & 73 & 20 & 4 & 3 \\
\hline Kaderberoepsgericht & 64 & 30 & 3 & 4 \\
\hline Basisberoepsgericht & 53 & 41 & 4 & 2 \\
\hline \multicolumn{5}{|l|}{ Naar sector } \\
\hline Landbouw & 62 & 32 & 4 & 3 \\
\hline Techniek & 47 & 43 & 6 & 4 \\
\hline Economie & 63 & 31 & 2 & 4 \\
\hline Gezondheidszorg & 68 & 26 & 4 & 2 \\
\hline Intersectoraal & 71 & 25 & 1 & 3 \\
\hline MBO & 26 & 17 & 50 & 7 \\
\hline BOL & 42 & 14 & 36 & 8 \\
\hline BOL niveau 1 & 49 & 29 & 8 & 14 \\
\hline BOL niveau 2 & 43 & 19 & 30 & 9 \\
\hline Landbouw & 41 & 19 & 28 & 12 \\
\hline Techniek & 36 & 28 & 28 & 9 \\
\hline Economie & 38 & 18 & 34 & 9 \\
\hline Gezondheidszorg & 51 & 14 & 27 & 8 \\
\hline BOL niveau 3 & 32 & 13 & 45 & 9 \\
\hline Landbouw & 25 & 19 & 48 & 8 \\
\hline Techniek & 36 & 21 & 28 & 15 \\
\hline Economie & 42 & 13 & 35 & 9 \\
\hline Gezondheidszorg & 25 & 14 & 53 & 7 \\
\hline Gedrag en maatschappij & 17 & 9 & 63 & 11 \\
\hline BOL niveau 4 & 45 & 11 & 38 & 6 \\
\hline Landbouw & 40 & 8 & 44 & 8 \\
\hline Techniek & 45 & 11 & 39 & 5 \\
\hline Economie & 50 & 11 & 32 & 7 \\
\hline Gezondheidszorg & 32 & 11 & 53 & 4 \\
\hline Gedrag en maatschappij & 47 & 15 & 33 & 5 \\
\hline
\end{tabular}




\section{Tabel 3}

Situatie op moment van enquête

\begin{tabular}{|c|c|c|c|c|}
\hline Opleidingssector & $\begin{array}{r}\text { studie } \\
\\
\%\end{array}$ & $\begin{array}{r}\text { combinatie werken- } \\
\text { leren } \\
\%\end{array}$ & $\begin{array}{r}\text { betaald werk } \\
\%\end{array}$ & $\begin{array}{r}\text { anders } \\
\%\end{array}$ \\
\hline BBL & 2 & 21 & 71 & 6 \\
\hline BBL niveau 1 & 1 & 24 & 69 & 7 \\
\hline BBL niveau 2 & 1 & 27 & 65 & 7 \\
\hline Landbouw & 4 & 21 & 66 & 9 \\
\hline Techniek & 1 & 32 & 64 & 3 \\
\hline Economie & 0 & 17 & 65 & 18 \\
\hline Gezondheidszorg & 1 & 25 & 69 & 5 \\
\hline BBL niveau 3 & 3 & 16 & 77 & 5 \\
\hline Landbouw & 4 & 13 & 81 & 2 \\
\hline Techniek & 3 & 21 & 76 & 0 \\
\hline Economie & 5 & 13 & 71 & 11 \\
\hline Gezondheidszorg & 0 & 12 & 83 & 5 \\
\hline Gedrag en maatschappij & 0 & 11 & 79 & 10 \\
\hline BBL niveau 4 & 4 & 16 & 75 & 6 \\
\hline Landbouw & - & - & - & \\
\hline Techniek & 4 & 18 & 72 & 7 \\
\hline Economie & 6 & 17 & 69 & 8 \\
\hline Gezondheidszorg & 1 & 16 & 81 & 2 \\
\hline Gedrag en maatschappij & 4 & 12 & 73 & 11 \\
\hline $\mathrm{HBO}$ & 15 & $x$ & 73 & 12 \\
\hline Landbouw & 19 & $x$ & 71 & 10 \\
\hline Onderwijs & 7 & $x$ & 81 & 12 \\
\hline Techniek & 19 & $x$ & 72 & 9 \\
\hline Economie & 21 & $x$ & 67 & 12 \\
\hline Gezondheidszorg & 6 & $x$ & 81 & 12 \\
\hline Gedrag en maatschappij & 11 & $x$ & 76 & 13 \\
\hline Taal en cultuur & 8 & $x$ & 71 & 21 \\
\hline Totaal & 46 & 16 & 32 & 6 \\
\hline
\end{tabular}

- te weinig waarnemingen

$\mathrm{x}=$ antwoordcategorie niet opgenomen

Bron: ROA (SIS) 
Tabel 4

Oordeel van gediplomeerde schoolverlaters: breedte en diepgang van gevolgde opleiding

\begin{tabular}{|c|c|c|c|}
\hline & $\begin{array}{r}\text { Bree } \\
\text { te smal } \\
\%\end{array}$ & $\begin{array}{r}\text { te breed } \\
\%\end{array}$ & $\begin{array}{r}\text { Diepgang } \\
\text { te weinig diepgang } \\
\%\end{array}$ \\
\hline HAVO/VWO & 3 & 7 & 8 \\
\hline HAVO & 3 & 6 & 8 \\
\hline vwo & 2 & 9 & 8 \\
\hline VMBO & 8 & 8 & 9 \\
\hline \multicolumn{4}{|l|}{ Naar leerweg } \\
\hline Theoretisch & 8 & 7 & 11 \\
\hline Gemengd & 5 & 10 & 10 \\
\hline Kaderberoepsgericht & 7 & 8 & 6 \\
\hline Basisberoepsgericht & 10 & 8 & 9 \\
\hline \multicolumn{4}{|l|}{ Naar sector } \\
\hline Landbouw & 8 & 8 & 8 \\
\hline Techniek & 12 & 6 & 11 \\
\hline Economie & 6 & 9 & 6 \\
\hline Gezondheidszorg & 5 & 9 & 7 \\
\hline Intersectoraal & 8 & 10 & 4 \\
\hline MBO & 9 & 9 & 15 \\
\hline BOL & 9 & 9 & 18 \\
\hline BOL niveau 1 & 8 & 8 & 8 \\
\hline BOL niveau 2 & 9 & 9 & 12 \\
\hline Landbouw & 10 & 12 & 12 \\
\hline Techniek & 10 & 6 & 15 \\
\hline Economie & 7 & 10 & 11 \\
\hline Gezondheidszorg & 10 & 10 & 11 \\
\hline BOL niveau 3 & 11 & 8 & 17 \\
\hline Landbouw & 16 & 7 & 23 \\
\hline Techniek & 7 & 16 & 16 \\
\hline Economie & 10 & 7 & 14 \\
\hline Gezondheidszorg & 7 & 9 & 15 \\
\hline Gedrag en maatschappij & 16 & 7 & 23 \\
\hline BOL niveau 4 & 9 & 10 & 21 \\
\hline Landbouw & 10 & 9 & 20 \\
\hline Techniek & 9 & 10 & 22 \\
\hline Economie & 10 & 9 & 19 \\
\hline Gezondheidszorg & 6 & 12 & 17 \\
\hline Gedrag en maatschappij & 9 & 11 & 29 \\
\hline
\end{tabular}


Tabel 4

Oordeel van gediplomeerde schoolverlaters: breedte en diepgang van gevolgde opleiding

\begin{tabular}{|c|c|c|c|}
\hline & $\begin{array}{r}\text { Bree } \\
\text { te smal } \\
\%\end{array}$ & $\begin{array}{r}\text { te breed } \\
\%\end{array}$ & $\begin{array}{r}\text { Diepgang } \\
\text { te weinig diepgang } \\
\%\end{array}$ \\
\hline BBL & 9 & 9 & 12 \\
\hline BBL niveau 1 & 11 & 13 & 9 \\
\hline BBL niveau 2 & 9 & 8 & 10 \\
\hline Landbouw & 7 & 13 & 7 \\
\hline Techniek & 9 & 8 & 11 \\
\hline Economie & 10 & 1 & 10 \\
\hline Gezondheidszorg & 6 & 9 & 7 \\
\hline BBL niveau 3 & 8 & 8 & 13 \\
\hline Landbouw & 18 & 2 & 23 \\
\hline Techniek & 4 & 5 & 5 \\
\hline Economie & 17 & 5 & 18 \\
\hline Gezondheidszorg & 4 & 15 & 14 \\
\hline Gedrag en maatschappij & 7 & 5 & 20 \\
\hline BBL niveau 4 & 7 & 11 & 13 \\
\hline Landbouw & - & - & - \\
\hline Techniek & 7 & 7 & 6 \\
\hline Economie & 5 & 11 & 9 \\
\hline Gezondheidszorg & 10 & 16 & 22 \\
\hline Gedrag en maatschappij & 8 & 8 & 11 \\
\hline HBO & 4 & 22 & 18 \\
\hline Landbouw & 2 & 29 & 19 \\
\hline Onderwijs & 9 & 7 & 18 \\
\hline Techniek & 3 & 21 & 16 \\
\hline Economie & 2 & 28 & 19 \\
\hline Gezondheidszorg & 6 & 15 & 17 \\
\hline Gedrag en maatschappij & 4 & 23 & 18 \\
\hline Totaal & 7 & 10 & 13 \\
\hline
\end{tabular}

- te weinig waarnemingen

Bron: ROA (SIS)

\section{Toelichting}

Vragen in de enquête:

Wat is uw oordeel over uw gevolgde opleiding met betrekking tot de breedte van de opleiding ( 1 'te weinig'tot $7^{\prime}$ te veel'). Vermeld is percentage van antwoordcategorie 1 en 2 (te smal) en antwoordcategorie 6 en 7 (te breed).

Wat is uw oordeel over uw gevolgde opleiding met betrekking tot de diepgang van de opleiding ( 1 'te weinig' tot 7 'te veel'). Vermeld is percentage van antwoordcategorie 1 en 2 (te weinig). 
Tabel 5

Oordeel van gediplomeerde schoolverlaters: basis om te starten op de arbeidsmarkt en basis om kennis en vaardigheden verder te ontwikkelen

\begin{tabular}{|c|c|c|}
\hline & $\begin{array}{r}\text { verder ontwikkelen } \\
\%\end{array}$ & $\begin{array}{r}\text { starten op arbeidsmarkt } \\
\%\end{array}$ \\
\hline VMBO & 55 & 25 \\
\hline \multicolumn{3}{|l|}{ Naar leerweg } \\
\hline Theoretisch & 57 & 22 \\
\hline Gemengd & 64 & 24 \\
\hline Kaderberoepsgericht & 52 & 25 \\
\hline Basisberoepsgericht & 52 & 31 \\
\hline \multicolumn{3}{|l|}{ Naar sector } \\
\hline Landbouw & 49 & 24 \\
\hline Techniek & 53 & 31 \\
\hline Economie & 55 & 28 \\
\hline Gezondheidszorg & 55 & 26 \\
\hline Intersectoraal & 58 & 23 \\
\hline MBO & 57 & 45 \\
\hline $\mathrm{BOL}$ & 55 & 41 \\
\hline BOL niveau 1 & 45 & 35 \\
\hline BOL niveau 2 & 57 & 40 \\
\hline Landbouw & 49 & 22 \\
\hline Techniek & 54 & 41 \\
\hline Economie & 53 & 43 \\
\hline Gezondheidszorg & 64 & 40 \\
\hline BOL niveau 3 & 55 & 46 \\
\hline Landbouw & 43 & 31 \\
\hline Techniek & 64 & 51 \\
\hline Economie & 52 & 41 \\
\hline Gezondheidszorg & 66 & 63 \\
\hline Gedrag en maatschappij & 51 & 42 \\
\hline BOL niveau 4 & 55 & 40 \\
\hline Landbouw & 58 & 42 \\
\hline Techniek & 60 & 46 \\
\hline Economie & 52 & 35 \\
\hline Gezondheidszorg & 60 & 50 \\
\hline Gedrag en maatschappij & 52 & 33 \\
\hline
\end{tabular}




\section{Tabel 5}

Oordeel van gediplomeerde schoolverlaters: basis om te starten op de arbeidsmarkt en basis om kennis en vaardigheden verder te ontwikkelen

\begin{tabular}{|c|c|c|}
\hline & $\begin{array}{r}\text { verder ontwikkelen } \\
\%\end{array}$ & $\begin{array}{r}\text { starten op arbeidsmarkt } \\
\%\end{array}$ \\
\hline$B B L$ & 59 & 51 \\
\hline BBL niveau 1 & 40 & 30 \\
\hline BBL niveau 2 & 54 & 45 \\
\hline Landbouw & 69 & 50 \\
\hline Techniek & 53 & 47 \\
\hline Economie & 39 & 28 \\
\hline Gezondheidszorg & 69 & 56 \\
\hline BBL niveau 3 & 64 & 56 \\
\hline Landbouw & 59 & 41 \\
\hline Techniek & 66 & 53 \\
\hline Economie & 57 & 47 \\
\hline Gezondheidszorg & 72 & 76 \\
\hline Gedrag en maatschappij & 64 & 52 \\
\hline BBL niveau 4 & 70 & 61 \\
\hline Landbouw & - & - \\
\hline Techniek & 70 & 51 \\
\hline Economie & 59 & 55 \\
\hline Gezondheidszorg & 79 & 76 \\
\hline Gedrag en maatschappij & 74 & 59 \\
\hline HBO & 63 & 48 \\
\hline Landbouw & 66 & 53 \\
\hline Onderwijs & 57 & 51 \\
\hline Techniek & 67 & 60 \\
\hline Economie & 63 & 48 \\
\hline Gezondheidszorg & 68 & 56 \\
\hline Gedrag en maatschappij & 57 & 38 \\
\hline Taal en cultuur & 68 & 26 \\
\hline Totaal & 57 & 39 \\
\hline
\end{tabular}

- te weinig waarnemingen

Bron: ROA (SIS)

\section{Toelichting}

In welke mate biedt uw gevolgde opleiding een goede basis om kennis en vaardigheden verder te ontwikkelen ( 1 'helemaal niet' tot 5 'in sterkte mate'). Vermeld is het percentage van antwoordcategorie 4 en 5 .

Vraag in de enquête:

In welke mate biedt uw gevolgde opleiding een goede basis om te starten op de arbeidsmarkt ( 1 'helemaal niet' tot 5 ' in sterke mate'). Vermeld is het percentage van antwoordcategorie 4 en 5. 
Tabel 6

Oordeel van gediplomeerde schoolverlaters: moeilijkheidsgraaf van opleiding

\begin{tabular}{|c|c|c|}
\hline & $\begin{array}{r}\text { te makkelijk } \\
\%\end{array}$ & $\begin{array}{r}\text { te moeilijk } \\
\%\end{array}$ \\
\hline HAVO/VWO & 10 & 5 \\
\hline HAVO & 8 & 5 \\
\hline VW0 & 12 & 5 \\
\hline VMBO & 14 & 5 \\
\hline \multicolumn{3}{|l|}{ Naar leerweg } \\
\hline Theoretisch & 19 & 5 \\
\hline Gemengd & 12 & 5 \\
\hline Kaderberoepsgericht & 11 & 6 \\
\hline Basisberoepsgericht & 12 & 6 \\
\hline \multicolumn{3}{|l|}{ Naar sector } \\
\hline Landbouw & 14 & 4 \\
\hline Techniek & 10 & 9 \\
\hline Economie & 16 & 6 \\
\hline Gezondheidszorg & 7 & 4 \\
\hline Intersectoraal & 11 & 4 \\
\hline MBO & 20 & 6 \\
\hline BOL & 23 & 5 \\
\hline BOL niveau 1 & 13 & 11 \\
\hline BOL niveau 2 & 16 & 9 \\
\hline Landbouw & 21 & 2 \\
\hline Techniek & 20 & 12 \\
\hline Economie & 16 & 8 \\
\hline Gezondheidszorg & 12 & 10 \\
\hline BOL niveau 3 & 17 & 6 \\
\hline Landbouw & 10 & 8 \\
\hline Techniek & 15 & 3 \\
\hline Economie & 22 & 6 \\
\hline Gezondheidszorg & 11 & 8 \\
\hline Gedrag en maatschappij & 18 & 4 \\
\hline BOL niveau 4 & 28 & 4 \\
\hline Landbouw & 26 & 4 \\
\hline Techniek & 30 & 4 \\
\hline Economie & 29 & 3 \\
\hline Gezondheidszorg & 23 & 4 \\
\hline Gedrag en maatschappij & 31 & 3 \\
\hline
\end{tabular}


Tabel 6

Oordeel van gediplomeerde schoolverlaters: moeilijkheidsgraaf van opleiding

\begin{tabular}{|c|c|c|}
\hline & $\begin{array}{r}\text { te makkelijk } \\
\%\end{array}$ & $\begin{array}{r}\text { te moeilijk } \\
\%\end{array}$ \\
\hline BBL & 16 & 7 \\
\hline BBL niveau 1 & 15 & 8 \\
\hline BBL niveau 2 & 16 & 6 \\
\hline Landbouw & 13 & 13 \\
\hline Techniek & 16 & 7 \\
\hline Economie & 18 & 3 \\
\hline Gezondheidszorg & 14 & 5 \\
\hline BBL niveau 3 & 14 & 8 \\
\hline Landbouw & 20 & 2 \\
\hline Techniek & 9 & 9 \\
\hline Economie & 20 & 5 \\
\hline Gezondheidszorg & 12 & 8 \\
\hline Gedrag en maatschappij & 20 & 12 \\
\hline BBL niveau 4 & 19 & 4 \\
\hline Landbouw & - & - \\
\hline Techniek & 14 & 5 \\
\hline Economie & 24 & 3 \\
\hline Gezondheidszorg & 22 & 7 \\
\hline Gedrag en maatschappij & 8 & \\
\hline HBO & 15 & 3 \\
\hline Landbouw & 12 & 4 \\
\hline Onderwijs & 18 & 3 \\
\hline Techniek & 13 & 5 \\
\hline Economie & 16 & 3 \\
\hline Gezondheidszorg & 10 & 5 \\
\hline Gedrag en maatschappij & 15 & 2 \\
\hline Totaal & 16 & 5 \\
\hline
\end{tabular}

- te weinig waarnemingen

Bron: ROA (SIS)

\section{Toelichting}

Vraag in de enquête:

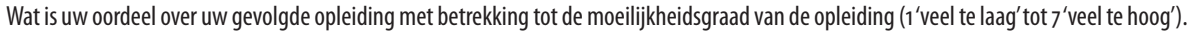
Vermeld is het percentage van antwoordcategorie 1 en 2 (te makkelijk) en 6 en 7 (te moeilijk). 
Tabel 7

Oordeel van gediplomeerde schoolverlaters: docenten streng in beoordeling studenten

\begin{tabular}{|c|c|c|}
\hline & $\begin{array}{r}\text { (helemaal) mee eens } \\
\%\end{array}$ & $\begin{array}{r}\text { (helemaal) mee oneens } \\
\%\end{array}$ \\
\hline HAVO/VWO & 30 & 26 \\
\hline HAVO & 31 & 27 \\
\hline VW0 & 30 & 26 \\
\hline VMBO & 23 & 29 \\
\hline \multicolumn{3}{|l|}{ Naar leerweg } \\
\hline Theoretisch & 21 & 29 \\
\hline Gemengd & 30 & 26 \\
\hline Kaderberoepsgericht & 22 & 32 \\
\hline Basisberoepsgericht & 27 & 25 \\
\hline \multicolumn{3}{|l|}{ Naar sector } \\
\hline Landbouw & 25 & 29 \\
\hline Techniek & 27 & 24 \\
\hline Economie & 21 & 35 \\
\hline Gezondheidszorg & 30 & 28 \\
\hline Intersectoraal & 20 & 29 \\
\hline MBO & 21 & 41 \\
\hline $\mathrm{BOL}$ & 22 & 41 \\
\hline BOL niveau 1 & 26 & 30 \\
\hline BOL niveau 2 & 26 & 34 \\
\hline Landbouw & 15 & 35 \\
\hline Techniek & 27 & 37 \\
\hline Economie & 27 & 36 \\
\hline Gezondheidszorg & 26 & 29 \\
\hline BOL niveau 3 & 24 & 36 \\
\hline Landbouw & 14 & 35 \\
\hline Techniek & 25 & 32 \\
\hline Economie & 23 & 39 \\
\hline Gezondheidszorg & 30 & 30 \\
\hline Gedrag en maatschappij & 22 & 39 \\
\hline BOL niveau 4 & 19 & 46 \\
\hline Landbouw & 16 & 50 \\
\hline Techniek & 23 & 45 \\
\hline Economie & 19 & 44 \\
\hline Gezondheidszorg & 18 & 46 \\
\hline Gedrag en maatschappij & 15 & 50 \\
\hline
\end{tabular}




\section{Tabel 7}

Oordeel van gediplomeerde schoolverlaters: docenten streng in beoordeling studenten

\begin{tabular}{|c|c|c|}
\hline & $\begin{array}{r}\text { (helemaal) mee eens } \\
\%\end{array}$ & $\begin{array}{r}\text { (helemaal) mee oneens } \\
\%\end{array}$ \\
\hline BBL & 21 & 41 \\
\hline BBL niveau 1 & 22 & 45 \\
\hline BBL niveau 2 & 21 & 41 \\
\hline Landbouw & 18 & 35 \\
\hline Techniek & 20 & 42 \\
\hline Economie & 22 & 37 \\
\hline Gezondheidszorg & 23 & 47 \\
\hline BBL niveau 3 & 19 & 40 \\
\hline Landbouw & 19 & 44 \\
\hline Techniek & 18 & 36 \\
\hline Economie & 23 & 42 \\
\hline Gezondheidszorg & 20 & 42 \\
\hline Gedrag en maatschappij & 18 & 40 \\
\hline BBL niveau 4 & 24 & 38 \\
\hline Landbouw & - & - \\
\hline Techniek & 15 & 43 \\
\hline Economie & 26 & 42 \\
\hline Gezondheidszorg & 25 & 39 \\
\hline Gedrag en maatschappij & 28 & 25 \\
\hline $\mathrm{HBO}$ & 26 & 34 \\
\hline Landbouw & 29 & 34 \\
\hline Onderwijs & 27 & 33 \\
\hline Techniek & 25 & 36 \\
\hline Economie & 26 & 34 \\
\hline Gezondheidszorg & 32 & 28 \\
\hline Gedrag en maatschappij & 23 & 37 \\
\hline Totaal & 24 & 34 \\
\hline
\end{tabular}

- te weinig waarnemingen

Bron: ROA (SIS)

\section{Toelichting}

Vraag in de enquête:

De docenten waren streng in de beoordeling van cursisten ( 1 'helemaal mee oneens' tot 5 'helemaal mee eens'). Vermeld is het percentage van antwoordcategorie 4 en 5 (helemaal mee eens) en 1 en 2 (helemaal mee oneens). 
Tabel 8

Oordeel van gediplomeerde schoolverlaters: uitdagend niveau

\begin{tabular}{|c|c|c|}
\hline & $\begin{array}{r}\text { (helemaal) mee eens } \\
\%\end{array}$ & $\begin{array}{r}\text { (helemaal) mee oneens } \\
\%\end{array}$ \\
\hline HAVO/VWO & 43 & 27 \\
\hline HAVO & 43 & 27 \\
\hline vwo & 44 & 27 \\
\hline VMBO & 33 & 32 \\
\hline \multicolumn{3}{|l|}{ Naar leerweg } \\
\hline Theoretisch & 29 & 37 \\
\hline Gemengd & 35 & 30 \\
\hline Kaderberoepsgericht & 35 & 27 \\
\hline Basisberoepsgericht & 38 & 30 \\
\hline \multicolumn{3}{|l|}{ Naar sector } \\
\hline Landbouw & 32 & 34 \\
\hline Techniek & 41 & 28 \\
\hline Economie & 33 & 28 \\
\hline Gezondheidszorg & 40 & 27 \\
\hline Intersectoraal & 32 & 29 \\
\hline MBO & 34 & 35 \\
\hline BOL & 31 & 38 \\
\hline BOL niveau 1 & 36 & 19 \\
\hline BOL niveau 2 & 34 & 33 \\
\hline Landbouw & 29 & 32 \\
\hline Techniek & 37 & 31 \\
\hline Economie & 34 & 37 \\
\hline Gezondheidszorg & 33 & 31 \\
\hline BOL niveau 3 & 32 & 37 \\
\hline Landbouw & 24 & 38 \\
\hline Techniek & 39 & 29 \\
\hline Economie & 31 & 42 \\
\hline Gezondheidszorg & 36 & 31 \\
\hline Gedrag en maatschappij & 31 & 38 \\
\hline BOL niveau 4 & 28 & 42 \\
\hline Landbouw & 33 & 38 \\
\hline Techniek & 31 & 40 \\
\hline Economie & 26 & 43 \\
\hline Gezondheidszorg & 32 & 34 \\
\hline Gedrag en maatschappij & 22 & 49 \\
\hline
\end{tabular}




\section{Tabel 8}

Oordeel van gediplomeerde schoolverlaters: uitdagend niveau

\begin{tabular}{|c|c|c|}
\hline & $\begin{array}{r}\text { (helemaal) mee eens } \\
\%\end{array}$ & $\begin{array}{r}\text { (helemaal) mee oneens } \\
\%\end{array}$ \\
\hline BBL & 38 & 30 \\
\hline BBL niveau 1 & 40 & 24 \\
\hline BBL niveau 2 & 39 & 31 \\
\hline Landbouw & 50 & 18 \\
\hline Techniek & 36 & 34 \\
\hline Economie & 34 & 34 \\
\hline Gezondheidszorg & 48 & 22 \\
\hline BBL niveau 3 & 38 & 30 \\
\hline Landbouw & 33 & 34 \\
\hline Techniek & 46 & 19 \\
\hline Economie & 32 & 36 \\
\hline Gezondheidszorg & 38 & 31 \\
\hline Gedrag en maatschappij & 27 & 46 \\
\hline BBL niveau 4 & 38 & 31 \\
\hline Landbouw & - & - \\
\hline Techniek & 55 & 23 \\
\hline Economie & 37 & 32 \\
\hline Gezondheidszorg & 30 & 41 \\
\hline Gedrag en maatschappij & 36 & 20 \\
\hline HBO & 41 & 28 \\
\hline Landbouw & 46 & 24 \\
\hline Onderwijs & 36 & 33 \\
\hline Techniek & 46 & 24 \\
\hline Economie & 38 & 30 \\
\hline Gezondheidszorg & 52 & 19 \\
\hline Gedrag en maatschappij & 38 & 30 \\
\hline Totaal & 37 & 32 \\
\hline
\end{tabular}

- te weinig waarnemingen

Bron: ROA (SIS)

\section{Toelichting}

Vraag in de enquête:

De opleiding was uitdagend met betrekking tot niveau ( 1 'helemaal mee oneens' tot 5 'helemaal mee eens'). Vermeld is het percentage van antwoordcategorie 4 en 5 (helemaal mee eens) en 1 en 2 (helemaal mee oneens). 
Tabel 9

Oordeel van gediplomeerde schoolverlaters: pittige examens/opdrachten

\begin{tabular}{|c|c|c|}
\hline & $\begin{array}{r}\text { (helemaal) mee eens } \\
\%\end{array}$ & $\begin{array}{r}\text { (helemaal) mee oneens } \\
\%\end{array}$ \\
\hline HAVO/VWO & 38 & 27 \\
\hline HAVO & 41 & 26 \\
\hline vwo & 35 & 28 \\
\hline VMBO & 32 & 28 \\
\hline \multicolumn{3}{|l|}{ Naar leerweg } \\
\hline Theoretisch & 30 & 31 \\
\hline Gemengd & 38 & 23 \\
\hline Kaderberoepsgericht & 33 & 23 \\
\hline Basisberoepsgericht & 31 & 30 \\
\hline \multicolumn{3}{|l|}{ Naar sector } \\
\hline Landbouw & 32 & 26 \\
\hline Techniek & 35 & 21 \\
\hline Economie & 30 & 31 \\
\hline Gezondheidszorg & 39 & 22 \\
\hline Intersectoraal & 20 & 32 \\
\hline MBO & 29 & 34 \\
\hline BOL & 27 & 37 \\
\hline BOL niveau 1 & 33 & 28 \\
\hline BOL niveau 2 & 30 & 30 \\
\hline Landbouw & 15 & 34 \\
\hline Techniek & 28 & 32 \\
\hline Economie & 33 & 30 \\
\hline Gezondheidszorg & 31 & 30 \\
\hline BOL niveau 3 & 29 & 32 \\
\hline Landbouw & 25 & 33 \\
\hline Techniek & 22 & 35 \\
\hline Economie & 26 & 37 \\
\hline Gezondheidszorg & 35 & 24 \\
\hline Gedrag en maatschappij & 33 & 30 \\
\hline B0L niveau 4 & 24 & 42 \\
\hline Landbouw & 19 & 38 \\
\hline Techniek & 25 & 42 \\
\hline Economie & 24 & 43 \\
\hline Gezondheidszorg & 27 & 34 \\
\hline Gedrag en maatschappij & 21 & 48 \\
\hline
\end{tabular}




\section{Tabel 9}

Oordeel van gediplomeerde schoolverlaters: pittige examens/opdrachten

\begin{tabular}{|c|c|c|}
\hline & $\begin{array}{r}\text { (helemaal) mee eens } \\
\%\end{array}$ & $\begin{array}{r}\text { (helemaal) mee oneens } \\
\%\end{array}$ \\
\hline BBL & 33 & 29 \\
\hline BBL niveau 1 & 37 & 31 \\
\hline BBL niveau 2 & 30 & 30 \\
\hline Landbouw & 40 & 25 \\
\hline Techniek & 28 & 33 \\
\hline Economie & 27 & 23 \\
\hline Gezondheidszorg & 40 & 28 \\
\hline BBL niveau 3 & 38 & 27 \\
\hline Landbouw & 36 & 36 \\
\hline Techniek & 45 & 22 \\
\hline Economie & 38 & 22 \\
\hline Gezondheidszorg & 35 & 34 \\
\hline Gedrag en maatschappij & 20 & 34 \\
\hline BBL niveau 4 & 29 & 30 \\
\hline Landbouw & - & - \\
\hline Techniek & 32 & 25 \\
\hline Economie & 27 & 35 \\
\hline Gezondheidszorg & 30 & 32 \\
\hline Gedrag en maatschappij & 26 & 21 \\
\hline HBO & 27 & 33 \\
\hline Landbouw & 27 & 33 \\
\hline Onderwijs & 26 & 37 \\
\hline Techniek & 28 & 30 \\
\hline Economie & 25 & 34 \\
\hline Gezondheidszorg & 37 & 25 \\
\hline Gedrag en maatschappij & 22 & 37 \\
\hline Totaal & 32 & 31 \\
\hline
\end{tabular}

- te weinig waarnemingen

Bron: ROA (SIS)

\section{Toelichting}

Vraag in de enquête:

De examens/opdrachten waren over het algemeen zeer pittig ( 1 'helemaal mee oneens' tot 5 'helemaal mee eens'). Vermeld is het percentage van antwoordcategorie 4 en 5 (helemaal mee eens) en 1 en 2 (helemaal mee oneens). 
Tabel 10

Oordeel van gediplomeerde schoolverlaters: toetsen op inzicht

\begin{tabular}{|c|c|c|}
\hline & $\begin{array}{r}\text { (helemaal) mee eens } \\
\%\end{array}$ & $\begin{array}{r}\text { (helemaal) mee oneens } \\
\%\end{array}$ \\
\hline HAVO/VWO & 52 & 19 \\
\hline HAVO & 53 & 17 \\
\hline vwo & 52 & 20 \\
\hline VMBO & 47 & 17 \\
\hline \multicolumn{3}{|l|}{ Naar leerweg } \\
\hline Theoretisch & 47 & 18 \\
\hline Gemengd & 52 & 20 \\
\hline Kaderberoepsgericht & 48 & 14 \\
\hline Basisberoepsgericht & 43 & 20 \\
\hline \multicolumn{3}{|l|}{ Naar sector } \\
\hline Landbouw & 46 & 16 \\
\hline Techniek & 48 & 15 \\
\hline Economie & 49 & 12 \\
\hline Gezondheidszorg & 51 & 21 \\
\hline Intersectoraal & 29 & 26 \\
\hline MBO & 40 & 25 \\
\hline BOL & 37 & 29 \\
\hline BOL niveau 1 & 43 & 18 \\
\hline BOL niveau 2 & 41 & 26 \\
\hline Landbouw & 33 & 28 \\
\hline Techniek & 42 & 24 \\
\hline Economie & 41 & 27 \\
\hline Gezondheidszorg & 42 & 26 \\
\hline BOL niveau 3 & 38 & 30 \\
\hline Landbouw & 30 & 26 \\
\hline Techniek & 49 & 22 \\
\hline Economie & 34 & 34 \\
\hline Gezondheidszorg & 47 & 24 \\
\hline Gedrag en maatschappij & 37 & 31 \\
\hline BOL niveau 4 & 35 & 30 \\
\hline Landbouw & 34 & 31 \\
\hline Techniek & 37 & 29 \\
\hline Economie & 36 & 28 \\
\hline Gezondheidszorg & 39 & 29 \\
\hline Gedrag en maatschappij & 28 & 38 \\
\hline
\end{tabular}




\section{Tabel 10}

Oordeel van gediplomeerde schoolverlaters: toetsen op inzicht

\begin{tabular}{|c|c|c|}
\hline & $\begin{array}{r}\text { (helemaal) mee eens } \\
\%\end{array}$ & $\begin{array}{r}\text { (helemaal) mee oneens } \\
\%\end{array}$ \\
\hline BBL & 45 & 20 \\
\hline BBL niveau 1 & 48 & 13 \\
\hline BBL niveau 2 & 46 & 21 \\
\hline Landbouw & 65 & 15 \\
\hline Techniek & 41 & 23 \\
\hline Economie & 38 & 22 \\
\hline Gezondheidszorg & 64 & 15 \\
\hline BBL niveau 3 & 43 & 20 \\
\hline Landbouw & 44 & 22 \\
\hline Techniek & 45 & 15 \\
\hline Economie & 40 & 22 \\
\hline Gezondheidszorg & 47 & 21 \\
\hline Gedrag en maatschappij & 33 & 30 \\
\hline BBL niveau 4 & 46 & 20 \\
\hline Landbouw & - & - \\
\hline Techniek & 47 & 18 \\
\hline Economie & 52 & 12 \\
\hline Gezondheidszorg & 33 & 34 \\
\hline Gedrag en maatschappij & 53 & 14 \\
\hline $\mathrm{HBO}$ & 42 & 22 \\
\hline Landbouw & 47 & 20 \\
\hline Onderwijs & 38 & 24 \\
\hline Techniek & 46 & 19 \\
\hline Economie & 41 & 22 \\
\hline Gezondheidszorg & 46 & 22 \\
\hline Gedrag en maatschappij & 38 & 26 \\
\hline Totaal & 45 & 22 \\
\hline
\end{tabular}

- te weinig waarnemingen

Bron: ROA (SIS)

\section{Toelichting}

Vraag in de enquête:

In de opleiding werd voldoende getoetst op inzicht ( 1 'helemaal mee oneens' tot 5 'helemaal mee eens'). Vermeld is het percentage van antwoordcategorie 4 en 5 (helemaal mee eens) en 1 en 2 (helemaal mee oneens). 
Tabel 11

Doorstroom en type vervolgonderwijs

\begin{tabular}{|c|c|c|c|c|c|c|c|c|c|}
\hline & $\begin{array}{r}\text { Vervolg- } \\
\text { opleiding } \\
\text { gevolgd } \\
\%\end{array}$ & $\begin{array}{r}\text { HAVO/ } \\
\text { VWO } \\
\%\end{array}$ & $\begin{array}{r}\text { BOL } \\
\text { niv. } \\
1 / 2 \\
\%\end{array}$ & $\begin{array}{r}\text { BOL } \\
\text { niv. } \\
3 / 4 \\
\%\end{array}$ & $\begin{array}{c}\text { BBL } \\
\text { niv. } \\
1 / 2 \\
\%\end{array}$ & \begin{tabular}{r|r|} 
BBL & \\
niv. & \\
$3 / 4$ & \\
$\%$ &
\end{tabular} & $\%$ & WO & anders \\
\hline HAVO/VWO & 87 & 0 & 0 & 2 & 0 & 0 & 52 & 32 & 1 \\
\hline HAVO & 87 & 0 & 0 & 3 & 0 & 0 & 81 & 0 & 1 \\
\hline VW0 & 88 & 0 & 0 & 0 & 0 & 0 & 13 & 73 & 1 \\
\hline VMBO & 98 & 8 & 16 & 57 & 8 & 5 & 0 & 0 & 1 \\
\hline \multicolumn{10}{|l|}{ Naar leerweg } \\
\hline Theoretisch & 98 & 17 & 1 & 71 & 2 & 4 & 0 & 0 & 1 \\
\hline Gemengd & 99 & 7 & 2 & 76 & 4 & 7 & 1 & 0 & 1 \\
\hline Kaderberoepsgericht & 98 & 0 & 9 & 68 & 10 & 7 & 0 & 0 & 1 \\
\hline Basisberoepsgericht & 97 & 0 & 61 & 7 & 21 & 4 & 0 & 0 & 1 \\
\hline \multicolumn{10}{|l|}{ Naar sector } \\
\hline Landbouw & 98 & 1 & 32 & 46 & 9 & 7 & 0 & 0 & 1 \\
\hline Techniek & 99 & 1 & 22 & 31 & 32 & 10 & 0 & 0 & 2 \\
\hline Economie & 96 & 2 & 28 & 52 & 7 & 3 & 0 & 0 & 0 \\
\hline Gezondheidszorg & 97 & 0 & 28 & 56 & 6 & 5 & 0 & 0 & 0 \\
\hline Intersectoraal & 98 & 3 & 27 & 49 & 7 & 5 & 0 & 0 & 0 \\
\hline MBO & 43 & 0 & 2 & 11 & 2 & 8 & 21 & 0 & 1 \\
\hline $\mathrm{BOL}$ & 56 & 0 & 3 & 16 & 1 & 4 & 30 & 0 & 1 \\
\hline BOL niveau 1 & 74 & 1 & 43 & 9 & 13 & 2 & 0 & 0 & 2 \\
\hline BOL niveau 2 & 59 & 0 & 4 & 41 & 2 & 11 & 1 & 0 & 0 \\
\hline Landbouw & 66 & 0 & 0 & 43 & 1 & 17 & 2 & 0 & 1 \\
\hline Techniek & 55 & 0 & 4 & 28 & 4 & 17 & 0 & 0 & 0 \\
\hline Economie & 53 & 0 & 4 & 38 & 1 & 7 & 2 & 0 & 1 \\
\hline Gezondheidszorg & 66 & 0 & 3 & 52 & 1 & 9 & 0 & 0 & 0 \\
\hline BOL niveau 3 & 45 & 0 & 0 & 24 & 1 & 5 & 14 & 0 & 1 \\
\hline Landbouw & 37 & 0 & 2 & 25 & 2 & 4 & 2 & 0 & 3 \\
\hline Techniek & 49 & 0 & 0 & 28 & 2 & 7 & 9 & 0 & 2 \\
\hline Economie & 55 & 0 & 0 & 25 & 0 & 4 & 23 & 0 & 1 \\
\hline Gezondheidszorg & 39 & 0 & 0 & 21 & 1 & 9 & 6 & 0 & 1 \\
\hline Gedrag en maatschappij & 34 & 0 & 0 & 22 & 0 & 4 & 8 & 0 & 1 \\
\hline BOL niveau 4 & 58 & 0 & 0 & 3 & 0 & 2 & 52 & 0 & 1 \\
\hline Landbouw & 50 & 0 & 0 & 7 & 0 & 3 & 38 & 0 & 0 \\
\hline Techniek & 56 & 0 & 0 & 2 & 0 & 1 & 51 & 0 & 1 \\
\hline Economie & 66 & 0 & 0 & 4 & 0 & 2 & 58 & 0 & 1 \\
\hline Gezondheidszorg & 43 & 0 & 0 & 2 & 0 & 1 & 38 & 0 & 1 \\
\hline Gedrag en maatschappij & 64 & 0 & 0 & 3 & 0 & 2 & 57 & 0 & 1 \\
\hline
\end{tabular}


Tabel 11

Doorstroom en type vervolgonderwijs

\begin{tabular}{|c|c|c|c|c|c|c|c|c|c|}
\hline & $\begin{array}{r}\text { Vervolg- } \\
\text { opleiding } \\
\text { gevolgd } \\
\%\end{array}$ & $\begin{array}{r}\text { HAV0/ } \\
\text { VWO } \\
\%\end{array}$ & $\begin{array}{r}\text { BOL } \\
\text { niv. } \\
1 / 2 \\
\%\end{array}$ & $\begin{array}{r}\text { BOL } \\
\text { niv. } \\
3 / 4 \\
\%\end{array}$ & $\begin{array}{r}\text { BBL } \\
\text { niv. } \\
1 / 2 \\
\%\end{array}$ & $\begin{array}{r}\text { BBL } \\
\text { niv. } \\
3 / 4 \\
\%\end{array}$ & HBO & $\begin{array}{l}\text { W0 } \\
\text { \% }\end{array}$ & anders \\
\hline BBL & 23 & 0 & 1 & 3 & 3 & 16 & 3 & 0 & 1 \\
\hline BBL niveau 1 & 20 & 0 & 2 & 2 & 7 & 5 & 0 & 0 & 1 \\
\hline BBL niveau 2 & 29 & 0 & 0 & 2 & 3 & 22 & 1 & 0 & 0 \\
\hline Landbouw & 32 & 0 & 2 & 3 & 2 & 23 & 0 & 0 & 0 \\
\hline Techniek & 32 & 0 & 0 & 2 & 3 & 24 & 0 & 0 & 0 \\
\hline Economie & 23 & 0 & 1 & 2 & 2 & 14 & 2 & 0 & 0 \\
\hline Gezondheidszorg & 25 & 0 & 0 & 0 & 0 & 0 & 0 & 0 & 0 \\
\hline BBL niveau 3 & 18 & 0 & 0 & 3 & 2 & 15 & 2 & 0 & 1 \\
\hline Landbouw & 18 & 0 & 0 & 0 & 0 & 0 & 0 & 0 & 0 \\
\hline Techniek & 26 & 0 & 0 & 4 & 1 & 16 & 2 & 0 & 1 \\
\hline Economie & 22 & 0 & 0 & 3 & 3 & 13 & 2 & 0 & 0 \\
\hline Gezondheidszorg & 7 & 0 & 0 & 0 & 0 & 0 & 0 & 0 & 0 \\
\hline Gedrag en maatschappij & 10 & 0 & 0 & 0 & 0 & 0 & 0 & 0 & 0 \\
\hline BBL niveau 4 & 19 & 0 & 0 & 2 & 0 & 9 & 13 & 0 & 1 \\
\hline Landbouw & - & - & - & - & - & - & - & - & - \\
\hline Techniek & 27 & 0 & 0 & 4 & 0 & 7 & 12 & 0 & 4 \\
\hline Economie & 26 & 0 & 0 & 2 & 0 & 11 & 13 & 0 & 0 \\
\hline Gezondheidszorg & 11 & 0 & 0 & 0 & 0 & 0 & 0 & 0 & 0 \\
\hline Gedrag en maatschappij & 14 & 0 & 0 & 0 & 0 & 0 & 0 & 0 & 0 \\
\hline HBO & 31 & 0 & 0 & 0 & 0 & 0 & 6 & 17 & 6 \\
\hline Landbouw & 27 & 0 & 0 & 1 & 0 & 0 & 6 & 16 & 5 \\
\hline Onderwijs & 30 & 0 & 0 & 0 & 0 & 0 & 12 & 8 & 9 \\
\hline Techniek & 28 & 0 & 0 & 0 & 0 & 0 & 4 & 20 & 3 \\
\hline Economie & 36 & 0 & 0 & 0 & 0 & 0 & 4 & 26 & 6 \\
\hline Gezondheidszorg & 25 & 0 & 0 & 0 & 0 & 0 & 7 & 10 & 8 \\
\hline Gedrag en maatschappij & 25 & 0 & 0 & 1 & 0 & 0 & 7 & 12 & 5 \\
\hline Taal en cultuur & 26 & 0 & 0 & 0 & 0 & 0 & 14 & 5 & 3 \\
\hline Totaal & 64 & 2 & 5 & 19 & 3 & 5 & 20 & 9 & 2 \\
\hline
\end{tabular}

- = te weinig waarnemingen

Bron: ROA (SIS) 


\section{Tabel 12}

Oordeel van schoolverlaters over de aansluiting van de afgesloten opleiding met de vervolgopleiding

\begin{tabular}{|c|c|c|c|c|}
\hline Opleidingssector & $\begin{array}{r}\text { goed } \\
\%\end{array}$ & $\begin{array}{r}\text { redelijk } \\
\%\end{array}$ & $\begin{array}{r}\text { matig } \\
\%\end{array}$ & $\begin{array}{r}\text { slecht } \\
\%\end{array}$ \\
\hline HAVO/VWO & 38 & 40 & 17 & 5 \\
\hline HAVO & 30 & 42 & 21 & 7 \\
\hline VW0 & 48 & 38 & 11 & 3 \\
\hline VMBO & 35 & 41 & 17 & 6 \\
\hline \multicolumn{5}{|l|}{ Naar leerweg } \\
\hline Theoretisch & 35 & 39 & 19 & 7 \\
\hline Gemengd & 39 & 41 & 16 & 4 \\
\hline Kaderberoepsgericht & 34 & 45 & 15 & 6 \\
\hline Basisberoepsgericht & 37 & 40 & 17 & 6 \\
\hline \multicolumn{5}{|l|}{ Naar sector } \\
\hline Landbouw & 34 & 41 & 17 & 8 \\
\hline Techniek & 36 & 42 & 16 & 6 \\
\hline Economie & 38 & 43 & 14 & 4 \\
\hline Gezondheidszorg & 35 & 43 & 16 & 7 \\
\hline Intersectoraal & 33 & 47 & 14 & 5 \\
\hline MBO & 36 & 35 & 19 & 11 \\
\hline $\mathrm{BOL}$ & 32 & 36 & 20 & 12 \\
\hline BOL niveau 1 & 51 & 33 & 10 & 6 \\
\hline BOL niveau 2 & 43 & 38 & 13 & 7 \\
\hline Landbouw & 43 & 38 & 14 & 5 \\
\hline Techniek & 38 & 45 & 11 & 7 \\
\hline Economie & 40 & 36 & 15 & 8 \\
\hline Gezondheidszorg & 47 & 36 & 12 & 5 \\
\hline BOL niveau 3 & 41 & 32 & 16 & 11 \\
\hline Landbouw & 44 & 23 & 14 & 19 \\
\hline Techniek & 44 & 39 & 17 & 0 \\
\hline Economie & 32 & 36 & 20 & 13 \\
\hline Gezondheidszorg & 49 & 30 & 10 & 11 \\
\hline Gedrag en maatschappij & 60 & 25 & 9 & 6 \\
\hline BOL niveau 4 & 23 & 37 & 25 & 15 \\
\hline Landbouw & 21 & 37 & 23 & 18 \\
\hline Techniek & 17 & 38 & 25 & 21 \\
\hline Economie & 27 & 33 & 28 & 13 \\
\hline Gezondheidszorg & 26 & 45 & 20 & 8 \\
\hline Gedrag en maatschappij & 19 & 38 & 25 & 17 \\
\hline
\end{tabular}




\section{Tabel 12}

Oordeel van schoolverlaters over de aansluiting van de afgesloten opleiding met de vervolgopleiding

\begin{tabular}{|c|c|c|c|c|}
\hline Opleidingssector & $\begin{array}{r}\text { goed } \\
\%\end{array}$ & $\begin{array}{r}\text { redelijk } \\
\%\end{array}$ & $\begin{array}{r}\text { matig } \\
\%\end{array}$ & $\begin{array}{r}\text { slecht } \\
\%\end{array}$ \\
\hline BBL & 51 & 30 & 13 & 6 \\
\hline BBL niveau 1 & 49 & 35 & 13 & 3 \\
\hline BBL niveau 2 & 60 & 26 & 10 & 4 \\
\hline BBL niveau 3 & 48 & 32 & 13 & 7 \\
\hline BBL niveau 4 & 30 & 33 & 23 & 14 \\
\hline HBO & 36 & 37 & 18 & 9 \\
\hline Landbouw & 40 & 36 & 13 & 11 \\
\hline Onderwijs & 46 & 37 & 13 & 5 \\
\hline Techniek & 32 & 36 & 19 & 13 \\
\hline Economie & 34 & 37 & 20 & 10 \\
\hline Gezondheidszorg & 45 & 35 & 14 & 6 \\
\hline Gedrag en maatschappij & 32 & 37 & 21 & 10 \\
\hline Totaal & 36 & 39 & 17 & 7 \\
\hline
\end{tabular}

Bron: ROA (SIS) 
Tabel 13

Uitvallers en studiewisselaars

\begin{tabular}{|c|c|c|}
\hline & $\begin{array}{r}\text { Vervolgopleiding voortijdig } \\
\text { verlaten } \\
\%\end{array}$ & $\begin{array}{r}\text { Studiewisselaar } \\
\%\end{array}$ \\
\hline HAVO/VWO & 20 & 17 \\
\hline HAVO & 26 & 21 \\
\hline vwo & 13 & 11 \\
\hline VMBO & 11 & 8 \\
\hline \multicolumn{3}{|l|}{ Naar leerweg } \\
\hline Theoretisch & 10 & 8 \\
\hline Gemengd & 13 & 11 \\
\hline Kaderberoepsgericht & 13 & 10 \\
\hline Basisberoepsgericht & 7 & 5 \\
\hline \multicolumn{3}{|l|}{ Naar sector } \\
\hline Landbouw & 8 & 7 \\
\hline Techniek & 9 & 6 \\
\hline Economie & 13 & 11 \\
\hline Gezondheidszorg & 10 & 8 \\
\hline Intersectoraal & 15 & 12 \\
\hline MBO & 11 & 4 \\
\hline BOL & 12 & 5 \\
\hline B0L niveau 1 & 13 & 6 \\
\hline BOL niveau 2 & 5 & 2 \\
\hline Landbouw & 9 & 0 \\
\hline Techniek & 2 & 2 \\
\hline Economie & 9 & 3 \\
\hline Gezondheidszorg & 5 & 1 \\
\hline BOL niveau 3 & 6 & 2 \\
\hline Landbouw & 3 & 0 \\
\hline Techniek & 0 & 0 \\
\hline Economie & 5 & 1 \\
\hline Gezondheidszorg & 11 & 3 \\
\hline Gedrag en maatschappij & 7 & 1 \\
\hline BOL niveau 4 & 17 & 7 \\
\hline Landbouw & 12 & 5 \\
\hline Techniek & 17 & 9 \\
\hline Economie & 18 & 6 \\
\hline Gezondheidszorg & 15 & 4 \\
\hline Gedrag en maatschappij & 16 & 7 \\
\hline
\end{tabular}




\section{Tabel 13}

Uitvallers en studiewisselaars

\begin{tabular}{|c|c|c|}
\hline & $\begin{array}{r}\text { Vervolgopleiding voortijdig } \\
\text { verlaten } \\
\%\end{array}$ & $\begin{array}{r}\text { Studiewisselaar } \\
\%\end{array}$ \\
\hline $\mathrm{BBL}$ & 6 & 1 \\
\hline BBL niveau 1 & 12 & 0 \\
\hline BBL niveau 2 & 6 & 0 \\
\hline BBL niveau 3 & 5 & 2 \\
\hline BBL niveau 4 & 8 & 2 \\
\hline HBO & 7 & 0 \\
\hline Landbouw & 4 & 0 \\
\hline Onderwijs & 3 & 0 \\
\hline Techniek & 8 & 0 \\
\hline Economie & 7 & 0 \\
\hline Gezondheidszorg & 4 & 0 \\
\hline Gedrag en maatschappij & 11 & 1 \\
\hline Taal en cultuur & 7 & 0 \\
\hline Totaal & 13 & 9 \\
\hline
\end{tabular}

Bron: ROA (SIS) 
Tabel 14

Werkloosheid

\begin{tabular}{|c|c|c|}
\hline & $\begin{array}{r}\text { aanbieden op arbeidsmarkt } \\
\%\end{array}$ & $\begin{array}{r}\text { werkloosheid } \\
\%\end{array}$ \\
\hline HAVO/VWO & 10 & 27 \\
\hline HAVO & 11 & 31 \\
\hline vwo & 9 & 20 \\
\hline VMBO & 24 & 15 \\
\hline \multicolumn{3}{|l|}{ Naar leerweg } \\
\hline Theoretisch & 13 & 24 \\
\hline Gemengd & 18 & 12 \\
\hline Kaderberoepsgericht & 30 & 15 \\
\hline Basisberoepsgericht & 39 & 11 \\
\hline \multicolumn{3}{|l|}{ Naar sector } \\
\hline Landbouw & 25 & 11 \\
\hline Techniek & 51 & 7 \\
\hline Economie & 27 & 23 \\
\hline Gezondheidszorg & 24 & 11 \\
\hline Intersectoraal & 25 & 20 \\
\hline MBO & 74 & 8 \\
\hline BOL & 56 & 14 \\
\hline BOL niveau 1 & 47 & 30 \\
\hline BOL niveau 2 & 53 & 19 \\
\hline Landbouw & 53 & 21 \\
\hline Techniek & 64 & 17 \\
\hline Economie & 55 & 18 \\
\hline Gezondheidszorg & 43 & 21 \\
\hline BOL niveau 3 & 65 & 15 \\
\hline Landbouw & 71 & 14 \\
\hline Techniek & 65 & 22 \\
\hline Economie & 54 & 19 \\
\hline Gezondheidszorg & 72 & 3 \\
\hline Gedrag en maatschappij & 76 & 19 \\
\hline BOL niveau 4 & 55 & 11 \\
\hline Landbouw & 56 & 16 \\
\hline Techniek & 56 & 6 \\
\hline Economie & 49 & 14 \\
\hline Gezondheidszorg & 70 & 6 \\
\hline Gedrag en maatschappij & 53 & 14 \\
\hline
\end{tabular}




\section{Tabel 14}

Werkloosheid

\begin{tabular}{|c|c|c|}
\hline & $\begin{array}{r}\text { aanbieden op arbeidsmarkt } \\
\%\end{array}$ & $\begin{array}{r}\text { werkloosheid } \\
\%\end{array}$ \\
\hline BBL & 96 & 3 \\
\hline BBL niveau 1 & 96 & 5 \\
\hline BBL niveau 2 & 97 & 4 \\
\hline Landbouw & 95 & 7 \\
\hline Techniek & 99 & 2 \\
\hline Economie & 92 & 11 \\
\hline Gezondheidszorg & 97 & 3 \\
\hline BBL niveau 3 & 96 & 2 \\
\hline Landbouw & 96 & 2 \\
\hline Techniek & 96 & 0 \\
\hline Economie & 94 & 7 \\
\hline Gezondheidszorg & 99 & 1 \\
\hline Gedrag en maatschappij & 95 & 6 \\
\hline BBL niveau 4 & 97 & 2 \\
\hline Landbouw & - & - \\
\hline Techniek & 96 & 0 \\
\hline Economie & 95 & 5 \\
\hline Gezondheidszorg & 99 & 0 \\
\hline Gedrag en maatschappij & 96 & 4 \\
\hline HBO & 84 & 9 \\
\hline Landbouw & 82 & 11 \\
\hline Onderwijs & 91 & 8 \\
\hline Techniek & 81 & 8 \\
\hline Economie & 79 & 10 \\
\hline Gezondheidszorg & 92 & 4 \\
\hline Gedrag en maatschappij & 88 & 9 \\
\hline Taal en cultuur & 90 & 12 \\
\hline Totaal & 52 & 10 \\
\hline
\end{tabular}

- te weinig waarnemingen

Bron: ROA (SIS)

\section{Toelichting}

Het werkloosheidspercentage heeft betrekking op de werkloze beroepsbevolking: schoolverlaters zonder werk (of met werk van minder dan 12 uur per week) die op zoek zijn naar betaald werk. Daarbij is tevens als voorwaarde gesteld dat de maatschappelijke positie niet scholier of student is. 
Tabel 15

Werkloosheid tot eerste baan

\begin{tabular}{|c|c|c|c|c|c|c|}
\hline Opleidingssector & $\begin{array}{r}0 \text { mnd. } \\
\%\end{array}$ & $\begin{array}{r}1-3 \text { mnd. } \\
\%\end{array}$ & $\begin{array}{r}4-6 \text { mnd. } \\
\%\end{array}$ & $\begin{array}{r}7-12 \text { mnd. } \\
\%\end{array}$ & $\begin{array}{r}>=13 \text { mnd. } \\
\%\end{array}$ & maanden \\
\hline VMBO & 86 & 6 & 3 & 3 & 2 & 0,9 \\
\hline \multicolumn{7}{|l|}{ Naar leerweg } \\
\hline Theoretisch & 88 & 6 & 3 & 2 & 1 & 0,7 \\
\hline Gemengd & 91 & 6 & 0 & 1 & 1 & 0,5 \\
\hline Kaderberoepsgericht & 84 & 6 & 3 & 3 & 4 & 1,2 \\
\hline Basisberoepsgericht & 82 & 7 & 5 & 4 & 2 & 1,2 \\
\hline \multicolumn{7}{|l|}{ Naar sector } \\
\hline Landbouw & 89 & 5 & 2 & 3 & 1 & 0,9 \\
\hline Techniek & 85 & 7 & 4 & 4 & 0 & 0,8 \\
\hline Economie & 75 & 10 & 5 & 4 & 6 & 1,8 \\
\hline Gezondheidszorg & 87 & 5 & 4 & 2 & 2 & 0,8 \\
\hline Intersectoraal & 88 & 3 & 1 & 1 & 6 & 1,2 \\
\hline MBO & 86 & 6 & 3 & 3 & 1 & 0,9 \\
\hline $\mathrm{BOL}$ & 82 & 8 & 4 & 4 & 2 & 1,2 \\
\hline BOL niveau 1 & 73 & 9 & 3 & 9 & 6 & 3,2 \\
\hline BOL niveau 2 & 77 & 9 & 6 & 6 & 2 & 1,6 \\
\hline Landbouw & 79 & 7 & 3 & 3 & 7 & 2,0 \\
\hline Techniek & 69 & 13 & 6 & 9 & 3 & 2,2 \\
\hline Economie & 75 & 9 & 8 & 6 & 2 & 1,8 \\
\hline Gezondheidszorg & 84 & 7 & 4 & 5 & 0 & 0,9 \\
\hline BOL niveau 3 & 79 & 10 & 5 & 4 & 2 & 1,2 \\
\hline Landbouw & 80 & 13 & 2 & 3 & 1 & 0,9 \\
\hline Techniek & 73 & 3 & 9 & 7 & 7 & 2,8 \\
\hline Economie & 71 & 15 & 7 & 6 & 1 & 1,5 \\
\hline Gezondheidszorg & 95 & 3 & 1 & 1 & 1 & 0,3 \\
\hline Gedrag en maatschappij & 81 & 11 & 5 & 1 & 3 & 1,1 \\
\hline BOL niveau 4 & 85 & 7 & 4 & 3 & 1 & 0,9 \\
\hline Landbouw & 83 & 9 & 2 & 5 & 1 & 0,9 \\
\hline Techniek & 85 & 7 & 3 & 3 & 1 & 0,8 \\
\hline Economie & 83 & 7 & 4 & 4 & 2 & 1,3 \\
\hline Gezondheidszorg & 91 & 4 & 4 & 1 & 0 & 0,5 \\
\hline Gedrag en maatschappij & 84 & 7 & 6 & 2 & 1 & 0,9 \\
\hline
\end{tabular}




\section{Tabel 15}

Werkloosheid tot eerste baan

\begin{tabular}{|c|c|c|c|c|c|c|}
\hline Opleidingssector & $\begin{array}{r}0 \text { mnd. } \\
\%\end{array}$ & $\begin{array}{r}1-3 \text { mnd. } \\
\%\end{array}$ & $\begin{array}{r}4-6 \mathrm{mnd} . \\
\%\end{array}$ & $\begin{array}{r}7-12 \text { mnd. } \\
\%\end{array}$ & $\begin{array}{r}>=13 \text { mnd. } \\
\%\end{array}$ & maanden \\
\hline BBL & 92 & 4 & 2 & 1 & 1 & 0,5 \\
\hline BBL niveau 1 & 89 & 2 & 1 & 4 & 3 & 1,5 \\
\hline BBL niveau 2 & 92 & 5 & 1 & 0 & 1 & 0,4 \\
\hline Landbouw & 95 & 4 & 2 & 0 & 0 & 0,2 \\
\hline Techniek & 92 & 6 & 1 & 0 & 0 & 0,3 \\
\hline Economie & 89 & 7 & 3 & 0 & 1 & 0,5 \\
\hline Gezondheidszorg & 96 & 1 & 0 & 1 & 1 & 0,5 \\
\hline BBL niveau 3 & 91 & 5 & 2 & 1 & 1 & 0,6 \\
\hline Landbouw & 93 & 3 & 2 & 2 & 0 & 0,4 \\
\hline Techniek & 91 & 7 & 1 & 0 & 1 & 0,7 \\
\hline Economie & 88 & 6 & 5 & 1 & 0 & 0,4 \\
\hline Gezondheidszorg & 96 & 1 & 2 & 0 & 2 & 0,7 \\
\hline Gedrag en maatschappij & 90 & 5 & 3 & 2 & 0 & 0,5 \\
\hline BBL niveau 4 & 97 & 1 & 1 & 1 & 0 & 0,2 \\
\hline Landbouw & - & - & - & - & - & - \\
\hline Techniek & 100 & 0 & 0 & 0 & 0 & 0,0 \\
\hline Economie & 97 & 1 & 2 & 0 & 0 & 0,1 \\
\hline Gezondheidszorg & 99 & 0 & 0 & 1 & 0 & 0,1 \\
\hline Gedrag en maatschappij & 89 & 4 & 2 & 4 & 2 & 0,9 \\
\hline HBO & 70 & 14 & 8 & 4 & 4 & 1,7 \\
\hline Landbouw & 68 & 13 & 8 & 5 & 5 & 2,0 \\
\hline Onderwijs & 72 & 14 & 7 & 3 & 4 & 1,7 \\
\hline Techniek & 73 & 13 & 6 & 4 & 3 & 1,5 \\
\hline Economie & 66 & 16 & 9 & 5 & 4 & 1,9 \\
\hline Gezondheidszorg & 81 & 12 & 4 & 2 & 2 & 0,8 \\
\hline Gedrag en maatschappij & 64 & 15 & 9 & 6 & 6 & 2,3 \\
\hline Taal en cultuur & 71 & 12 & 10 & 6 & 1 & 1,6 \\
\hline Totaal & 83 & 8 & 4 & 3 & 2 & 1,1 \\
\hline
\end{tabular}

- = te weinig waarnemingen

Bron: ROA (SIS) 
Tabel 16

Werkzaam in klein-, midden-, grootbedrijf

\begin{tabular}{|c|c|c|c|}
\hline Opleidingssector & $\begin{array}{r}1-9 \text { personen } \\
\%\end{array}$ & $\begin{array}{r}10-99 \text { personen } \\
\%\end{array}$ & $\begin{array}{r}>=100 \text { personen } \\
\%\end{array}$ \\
\hline VMBO & 25 & 42 & 33 \\
\hline \multicolumn{4}{|l|}{ Naar leerweg } \\
\hline Theoretisch & 32 & 30 & 38 \\
\hline Gemengd & 30 & 42 & 28 \\
\hline Kaderberoepsgericht & 22 & 51 & 27 \\
\hline Basisberoepsgericht & 25 & 40 & 35 \\
\hline \multicolumn{4}{|l|}{ Naar sector } \\
\hline Landbouw & 29 & 45 & 25 \\
\hline Techniek & 32 & 51 & 18 \\
\hline Economie & 22 & 48 & 29 \\
\hline Gezondheidszorg & 13 & 29 & 58 \\
\hline Intersectoraal & 1 & 47 & 52 \\
\hline MBO & 16 & 27 & 56 \\
\hline BOL & 20 & 29 & 51 \\
\hline BOL niveau 1 & 15 & 31 & 54 \\
\hline BOL niveau 2 & 25 & 27 & 48 \\
\hline Landbouw & 36 & 50 & 14 \\
\hline Techniek & 37 & 26 & 38 \\
\hline Economie & 16 & 30 & 55 \\
\hline Gezondheidszorg & 22 & 22 & 56 \\
\hline BOL niveau 3 & 21 & 29 & 50 \\
\hline Landbouw & 48 & 20 & 31 \\
\hline Techniek & 29 & 38 & 33 \\
\hline Economie & 24 & 36 & 40 \\
\hline Gezondheidszorg & 18 & 20 & 62 \\
\hline Gedrag en maatschappij & 10 & 29 & 60 \\
\hline B0L niveau 4 & 17 & 30 & 53 \\
\hline Landbouw & 38 & 33 & 29 \\
\hline Techniek & 18 & 38 & 43 \\
\hline Economie & 18 & 33 & 48 \\
\hline Gezondheidszorg & 16 & 24 & 60 \\
\hline Gedrag en maatschappij & 8 & 20 & 71 \\
\hline
\end{tabular}




\section{Tabel 16}

Werkzaam in klein-, midden-, grootbedrijf

\begin{tabular}{|c|c|c|c|}
\hline Opleidingssector & $\begin{array}{r}1-9 \text { personen } \\
\%\end{array}$ & $\begin{array}{r}10-99 \text { personen } \\
\%\end{array}$ & $\begin{array}{r}>=100 \text { personen } \\
\%\end{array}$ \\
\hline BBL & 14 & 26 & 60 \\
\hline BBL niveau 1 & 9 & 25 & 66 \\
\hline BBL niveau 2 & 17 & 27 & 57 \\
\hline Landbouw & 21 & 33 & 46 \\
\hline Techniek & 18 & 26 & 56 \\
\hline Economie & 15 & 29 & 56 \\
\hline Gezondheidszorg & 11 & 23 & 66 \\
\hline BBL niveau 3 & 16 & 29 & 55 \\
\hline Landbouw & 34 & 22 & 44 \\
\hline Techniek & 23 & 39 & 38 \\
\hline Economie & 12 & 39 & 50 \\
\hline Gezondheidszorg & 7 & 11 & 82 \\
\hline Gedrag en maatschappij & 8 & 17 & 75 \\
\hline BBL niveau 4 & 9 & 19 & 72 \\
\hline Landbouw & - & - & - \\
\hline Techniek & 17 & 25 & 58 \\
\hline Economie & 11 & 33 & 55 \\
\hline Gezondheidszorg & 5 & 5 & 89 \\
\hline Gedrag en maatschappij & & 9 & 91 \\
\hline HBO & 16 & 28 & 55 \\
\hline Landbouw & 21 & 29 & 50 \\
\hline Onderwijs & 6 & 47 & 47 \\
\hline Techniek & 12 & 30 & 57 \\
\hline Economie & 11 & 28 & 61 \\
\hline Gezondheidszorg & 26 & 22 & 51 \\
\hline Gedrag en maatschappij & 6 & 22 & 72 \\
\hline Taal en cultuur & 64 & 15 & 21 \\
\hline Totaal & 17 & 29 & 54 \\
\hline
\end{tabular}

- = te weinig waarnemingen

Bron: ROA (SIS) 


\section{Tabel 17}

Percentage werkende schoolverlaters met een flexibele aanstelling

\begin{tabular}{|c|c|}
\hline Opleidingssector & $\%$ \\
\hline HAVO/VWO & 75 \\
\hline HAVO & 80 \\
\hline Vw0 & 69 \\
\hline VMBO & 65 \\
\hline \multicolumn{2}{|l|}{ Naarleerweg } \\
\hline Theoretisch & 70 \\
\hline Gemengd & 29 \\
\hline Kaderberoepsgericht & 65 \\
\hline Basisberoepsgericht & 70 \\
\hline \multicolumn{2}{|l|}{ Naar sector } \\
\hline Landbouw & 60 \\
\hline Techniek & 67 \\
\hline Economie & 51 \\
\hline Gezondheidszorg & 73 \\
\hline Intersectoraal & 54 \\
\hline MBO & 40 \\
\hline BOL & 61 \\
\hline BOL niveau 1 & 79 \\
\hline BOL niveau 2 & 65 \\
\hline Landbouw & 82 \\
\hline Techniek & 67 \\
\hline Economie & 59 \\
\hline Gezondheidszorg & 69 \\
\hline BOL niveau 3 & 58 \\
\hline Landbouw & 57 \\
\hline Techniek & 56 \\
\hline Economie & 62 \\
\hline Gezondheidszorg & 47 \\
\hline Gedrag en maatschappij & 67 \\
\hline BOL niveau 4 & 59 \\
\hline Landbouw & 57 \\
\hline Techniek & 52 \\
\hline Economie & 67 \\
\hline Gezondheidszorg & 54 \\
\hline Gedrag en maatschappij & 63 \\
\hline
\end{tabular}




\section{Tabel 17}

Percentage werkende schoolverlaters met een flexibele aanstelling

\begin{tabular}{|c|c|}
\hline Opleidingssector & $\%$ \\
\hline BBL & 28 \\
\hline BBL niveau 1 & 17 \\
\hline BBL niveau 2 & 33 \\
\hline Landbouw & 28 \\
\hline Techniek & 35 \\
\hline Economie & 32 \\
\hline Gezondheidszorg & 26 \\
\hline BBL niveau 3 & 31 \\
\hline Landbouw & 15 \\
\hline Techniek & 34 \\
\hline Economie & 40 \\
\hline Gezondheidszorg & 24 \\
\hline Gedrag en maatschappij & 18 \\
\hline BBL niveau 4 & 18 \\
\hline Landbouw & - \\
\hline Techniek & 5 \\
\hline Economie & 24 \\
\hline Gezondheidszorg & 18 \\
\hline Gedrag en maatschappij & 27 \\
\hline HBO & 58 \\
\hline Landbouw & 61 \\
\hline Onderwijs & 65 \\
\hline Techniek & 49 \\
\hline Economie & 58 \\
\hline Gezondheidszorg & 51 \\
\hline Gedrag en maatschappij & 66 \\
\hline Taal en cultuur & 64 \\
\hline Totaal & 48 \\
\hline
\end{tabular}

- = te weinig waarnemingen

Bron: ROA (SIS)

\section{Toelichting}

Een flexibele aanstelling betreft een aanstelling als uitzendkracht, oproepkracht e.d. of een aanstelling in tijdelijke dienst. 
Tabel 18

Wekelijkse arbeidsduur van werkende schoolverlaters

\begin{tabular}{|c|c|c|}
\hline Opleidingssector & $\begin{array}{r}\text { deeltijdaanstelling } \\
\%\end{array}$ & $\begin{array}{l}\text { wekelijkse } \\
\text { arbeidsduur uren }\end{array}$ \\
\hline HAVO/VWO & 76 & 24,2 \\
\hline HAVO & 70 & 27,4 \\
\hline vwo & 84 & 20,2 \\
\hline VMBO & 70 & 28,0 \\
\hline \multicolumn{3}{|l|}{ Naarleerweg } \\
\hline Theoretisch & 79 & 23,4 \\
\hline Gemengd & 70 & 28,6 \\
\hline Kaderberoepsgericht & 69 & 28,3 \\
\hline Basisberoepsgericht & 66 & 29,8 \\
\hline \multicolumn{3}{|l|}{ Naar sector } \\
\hline Landbouw & 75 & 28,3 \\
\hline Techniek & 45 & 34,7 \\
\hline Economie & 91 & 23,2 \\
\hline Gezondheidszorg & 87 & 23,6 \\
\hline Intersectoraal & 79 & 25,7 \\
\hline MBO & 47 & 32,6 \\
\hline BOL & 55 & 31,1 \\
\hline BOL niveau 1 & 69 & 28,1 \\
\hline BOL niveau 2 & 60 & 30,4 \\
\hline Landbouw & 68 & 31,4 \\
\hline Techniek & 35 & 35,4 \\
\hline Economie & 57 & 30,0 \\
\hline Gezondheidszorg & 90 & 25,3 \\
\hline BOL niveau 3 & 63 & 29,8 \\
\hline Landbouw & 57 & 31,3 \\
\hline Techniek & 19 & 37,2 \\
\hline Economie & 50 & 31,9 \\
\hline Gezondheidszorg & 81 & 27,6 \\
\hline Gedrag en maatschappij & 82 & 26,3 \\
\hline BOL niveau 4 & 50 & 32,1 \\
\hline Landbouw & 42 & 32,9 \\
\hline Techniek & 25 & 36,3 \\
\hline Economie & 42 & 33,2 \\
\hline Gezondheidszorg & 66 & 29,7 \\
\hline Gedrag en maatschappij & 80 & 26,7 \\
\hline
\end{tabular}




\section{Tabel 18}

Wekelijkse arbeidsduur van werkende schoolverlaters

\begin{tabular}{|c|c|c|}
\hline Opleidingssector & $\begin{array}{r}\text { deeltijdaanstelling } \\
\%\end{array}$ & $\begin{array}{l}\text { wekelijkse } \\
\text { arbeidsduur uren }\end{array}$ \\
\hline BBL & 41 & 33,6 \\
\hline BBL niveau 1 & 42 & 32,6 \\
\hline BBL niveau 2 & 36 & 34,5 \\
\hline Landbouw & 34 & 35,1 \\
\hline Techniek & 19 & 37,1 \\
\hline Economie & 63 & 30,2 \\
\hline Gezondheidszorg & 80 & 27,5 \\
\hline BBL niveau 3 & 42 & 33,6 \\
\hline Landbouw & 11 & 37,1 \\
\hline Techniek & 4 & 38,9 \\
\hline Economie & 40 & 34,1 \\
\hline Gezondheidszorg & 92 & 27,2 \\
\hline Gedrag en maatschappij & 81 & 25,8 \\
\hline BBL niveau 4 & 51 & 32,2 \\
\hline Landbouw & - & - \\
\hline Techniek & 9 & 37,7 \\
\hline Economie & 49 & 32,9 \\
\hline Gezondheidszorg & 76 & 29,3 \\
\hline Gedrag en maatschappij & 72 & 28,8 \\
\hline HBO & 38 & 35,2 \\
\hline Landbouw & 26 & 37,4 \\
\hline Onderwijs & 55 & 32,1 \\
\hline Techniek & 10 & 39,0 \\
\hline Economie & 19 & 37,4 \\
\hline Gezondheidszorg & 61 & 32,3 \\
\hline Gedrag en maatschappij & 73 & 30,4 \\
\hline Taal en cultuur & 57 & 35,6 \\
\hline Totaal & 48 & 32,5 \\
\hline
\end{tabular}

- = te weinig waarnemingen

Bron: ROA (SIS)

\section{Toelichting}

De arbeidsduur betreft zowel het aantal uren in de hoofdfunctie als het aantal uren in eventuele nevenfuncties (HBO). Een deeltijdaanstelling is een aanstelling met minder dan 33 arbeidsuren per week. 
Tabel 19

Aard van het dienstverband van werkende schoolverlaters

\begin{tabular}{|c|c|c|c|c|c|}
\hline Opleidingssector & $\begin{array}{r}\text { leer/werk- } \\
\text { overeenkomst } \\
\%\end{array}$ & $\begin{array}{r}\text { uitzend-, } \\
\text { oproepkracht } \\
\%\end{array}$ & $\begin{array}{r}\text { loondienst } \\
\text { werkgever } \\
\%\end{array}$ & $\begin{array}{r}\text { bedrijf ouders/ } \\
\text { partner } \\
\%\end{array}$ & $\begin{array}{r}\text { eigen bedrijf/ } \\
\text { free-lance } \\
\%\end{array}$ \\
\hline HAVO/VWO & 15 & 17 & 56 & 0 & 10 \\
\hline HAVO & 23 & 10 & 57 & 0 & 10 \\
\hline VWo & 4 & 26 & 54 & 0 & 10 \\
\hline VMBO & 59 & 4 & 28 & 1 & 1 \\
\hline \multicolumn{6}{|l|}{ Naar leerweg } \\
\hline Theoretisch & 40 & 11 & 41 & 2 & 3 \\
\hline Gemengd & 50 & 1 & 46 & 0 & 0 \\
\hline Kaderberoepsgericht & 58 & 2 & 29 & 0 & 0 \\
\hline Basisberoepsgericht & 69 & 2 & 19 & 2 & 0 \\
\hline \multicolumn{6}{|l|}{ Naar sector } \\
\hline Landbouw & 58 & 3 & 29 & 1 & 0 \\
\hline Techniek & 81 & 0 & 15 & 3 & 0 \\
\hline Economie & 50 & 0 & 34 & 0 & 0 \\
\hline Gezondheidszorg & 46 & 8 & 31 & 0 & 0 \\
\hline Intersectoraal & 40 & 0 & 49 & 0 & 0 \\
\hline MBO & 16 & 6 & 74 & 1 & 2 \\
\hline BOL & 11 & 10 & 72 & 1 & 3 \\
\hline BOL niveau 1 & 39 & 8 & 41 & 3 & 0 \\
\hline BOL niveau 2 & 19 & 13 & 60 & 1 & 3 \\
\hline Landbouw & 27 & 9 & 55 & 4 & 0 \\
\hline Techniek & 30 & 11 & 42 & 2 & 9 \\
\hline Economie & 10 & 17 & 71 & 0 & 2 \\
\hline Gezondheidszorg & 17 & 9 & 67 & 0 & 0 \\
\hline BOL niveau 3 & 10 & 12 & 71 & 1 & 3 \\
\hline Landbouw & 6 & 15 & 76 & 0 & 4 \\
\hline Techniek & 26 & 12 & 52 & 0 & 10 \\
\hline Economie & 9 & 15 & 70 & 3 & 1 \\
\hline Gezondheidszorg & 12 & 6 & 72 & 2 & 4 \\
\hline Gedrag en maatschappij & 4 & 13 & 79 & 0 & 2 \\
\hline BOL niveau 4 & 8 & 8 & 79 & 0 & 3 \\
\hline Landbouw & 7 & 7 & 82 & 1 & 3 \\
\hline Techniek & 7 & 9 & 75 & 1 & 5 \\
\hline Economie & 8 & 10 & 78 & 1 & 2 \\
\hline Gezondheidszorg & 6 & 4 & 85 & 0 & 1 \\
\hline Gedrag en maatschappij & 8 & 9 & 77 & 0 & 2 \\
\hline
\end{tabular}




\section{Tabel 19}

Aard van het dienstverband van werkende schoolverlaters

\begin{tabular}{|c|c|c|c|c|c|}
\hline Opleidingssector & $\begin{array}{r}\text { leer/werk- } \\
\text { overeenkomst } \\
\%\end{array}$ & $\begin{array}{r}\text { uitzend-, } \\
\text { oproepkracht } \\
\%\end{array}$ & $\begin{array}{r}\text { loondienst } \\
\text { werkgever } \\
\%\end{array}$ & $\begin{array}{r}\text { bedrijf ouders/ } \\
\text { partner } \\
\%\end{array}$ & $\begin{array}{r}\text { eigen bedriif/ } \\
\text { free-lance } \\
\%\end{array}$ \\
\hline BBL & 19 & 3 & 75 & 0 & 1 \\
\hline BBL niveau 1 & 7 & 1 & 85 & 1 & 0 \\
\hline BBL niveau 2 & 21 & 3 & 72 & 0 & 0 \\
\hline Landbouw & 8 & 2 & 90 & 0 & 0 \\
\hline Techniek & 24 & 4 & 70 & 0 & 0 \\
\hline Economie & 14 & 2 & 76 & 0 & 0 \\
\hline Gezondheidszorg & 26 & 0 & 69 & 0 & 2 \\
\hline BBL niveau 3 & 21 & 5 & 71 & 0 & 2 \\
\hline Landbouw & 16 & 0 & 79 & 0 & 2 \\
\hline Techniek & 24 & 7 & 64 & 1 & 3 \\
\hline Economie & 14 & 9 & 73 & 0 & 0 \\
\hline Gezondheidszorg & 26 & 0 & 72 & 0 & 1 \\
\hline Gedrag en maatschappij & 12 & 0 & 84 & 0 & 4 \\
\hline BBL niveau 4 & 15 & 1 & 81 & 1 & 0 \\
\hline Landbouw & - & - & - & - & - \\
\hline Techniek & 2 & 0 & 93 & 2 & 1 \\
\hline Economie & 19 & 0 & 77 & 2 & 0 \\
\hline Gezondheidszorg & 20 & 0 & 77 & 0 & 0 \\
\hline Gedrag en maatschappij & 18 & 2 & 80 & 0 & 0 \\
\hline HBO & 0 & 10 & 80 & 0 & 8 \\
\hline Landbouw & 0 & 10 & 78 & 2 & 7 \\
\hline Onderwijs & 0 & 20 & 75 & 0 & 2 \\
\hline Techniek & 0 & 6 & 87 & 0 & 5 \\
\hline Economie & 0 & 10 & 84 & 1 & 3 \\
\hline Gezondheidszorg & 0 & 3 & 89 & 0 & 7 \\
\hline Gedrag en maatschappij & 0 & 13 & 83 & 0 & 2 \\
\hline Taal en cultuur & 0 & 4 & 37 & 0 & 55 \\
\hline Totaal & 16 & 7 & 70 & 1 & 3 \\
\hline
\end{tabular}

- = te weinig waarnemingen

Bron: ROA (SIS) 
Tabel 20

Vereist opleidingsniveau voor de huidige functie volgens de werkgever

\begin{tabular}{|c|c|c|c|}
\hline Opleidingssector & $\begin{array}{r}\text { lager } \\
\%\end{array}$ & $\begin{array}{r}\text { zelfde } \\
\%\end{array}$ & $\begin{array}{r}\text { hoger } \\
\%\end{array}$ \\
\hline VMBO & 18 & 32 & 50 \\
\hline \multicolumn{4}{|l|}{ Naar leerweg } \\
\hline Theoretisch & 38 & 25 & 37 \\
\hline Gemengd & 32 & 12 & 56 \\
\hline Kaderberoepsgericht & 14 & 36 & 50 \\
\hline Basisberoepsgericht & 11 & 35 & 54 \\
\hline \multicolumn{4}{|l|}{ Naar sector } \\
\hline Landbouw & 15 & 23 & 63 \\
\hline Techniek & 6 & 41 & 53 \\
\hline Economie & 22 & 25 & 53 \\
\hline Gezondheidszorg & 15 & 38 & 47 \\
\hline Intersectoraal & 35 & 13 & 52 \\
\hline MBO & 29 & 63 & 8 \\
\hline $\mathrm{BOL}$ & 25 & 67 & 8 \\
\hline BOL niveau 1 & 19 & 64 & 17 \\
\hline BOL niveau 2 & 31 & 48 & 21 \\
\hline Landbouw & 27 & 32 & 41 \\
\hline Techniek & 33 & 46 & 21 \\
\hline Economie & 34 & 46 & 20 \\
\hline Gezondheidszorg & 24 & 56 & 20 \\
\hline BOL niveau 3 & 30 & 68 & 2 \\
\hline Landbouw & 47 & 53 & \\
\hline Techniek & 38 & 62 & \\
\hline Economie & 35 & 59 & 6 \\
\hline Gezondheidszorg & 18 & 82 & \\
\hline Gedrag en maatschappij & 28 & 72 & \\
\hline BOL niveau 4 & 21 & 74 & 6 \\
\hline Landbouw & 28 & 69 & 3 \\
\hline Techniek & 21 & 73 & 6 \\
\hline Economie & 27 & 64 & 9 \\
\hline Gezondheidszorg & 10 & 89 & 1 \\
\hline Gedrag en maatschappij & 20 & 75 & 5 \\
\hline
\end{tabular}




\section{Tabel 20}

Vereist opleidingsniveau voor de huidige functie volgens de werkgever

\begin{tabular}{|c|c|c|c|}
\hline Opleidingssector & $\begin{array}{r}\text { lager } \\
\%\end{array}$ & $\begin{array}{r}\text { zelfde } \\
\%\end{array}$ & $\begin{array}{r}\text { hoger } \\
\%\end{array}$ \\
\hline BBL & 31 & 60 & 8 \\
\hline BBL niveau 1 & 56 & 36 & 8 \\
\hline BBL niveau 2 & 31 & 49 & 20 \\
\hline Landbouw & 43 & 43 & 14 \\
\hline Techniek & 33 & 48 & 19 \\
\hline Economie & 42 & 46 & 12 \\
\hline Gezondheidszorg & 6 & 60 & 33 \\
\hline BBL niveau 3 & 33 & 67 & \\
\hline Landbouw & 48 & 52 & \\
\hline Techniek & 37 & 63 & \\
\hline Economie & 34 & 66 & \\
\hline Gezondheidszorg & 29 & 71 & \\
\hline Gedrag en maatschappij & 12 & 88 & \\
\hline BBL niveau 4 & 17 & 80 & 3 \\
\hline Landbouw & - & - & - \\
\hline Techniek & 23 & 77 & \\
\hline Economie & 31 & 64 & 5 \\
\hline Gezondheidszorg & 5 & 94 & 1 \\
\hline Gedrag en maatschappij & 12 & 83 & 5 \\
\hline HBO & 24 & 75 & 2 \\
\hline Landbouw & 28 & 71 & 1 \\
\hline Onderwijs & 10 & 89 & 1 \\
\hline Techniek & 14 & 85 & 2 \\
\hline Economie & 23 & 74 & 3 \\
\hline Gezondheidszorg & 19 & 80 & 0 \\
\hline Gedrag en maatschappij & 49 & 51 & 1 \\
\hline Taal en cultuur & 37 & 61 & 3 \\
\hline Totaal & 28 & 61 & 11 \\
\hline
\end{tabular}

- te weinig waarnemingen

Bron: ROA (SIS)

\section{Toelichting}

Vraag in de enquête:

Welk opleidingsniveau werd door uw werkgever voor deze functie minimaal vereist? 


\section{Tabel 21}

Vereiste opleidingsrichting voor de huidige functie volgens de werkgever

\begin{tabular}{|c|c|c|}
\hline Opleidingssector & $\begin{array}{r}\text { eigen/verwante } \\
\text { richting } \\
\%\end{array}$ & $\begin{array}{r}\text { geen/andere } \\
\text { richting } \\
\%\end{array}$ \\
\hline VMBO & 61 & 39 \\
\hline \multicolumn{3}{|l|}{ Naar leerweg } \\
\hline Theoretisch & 38 & 62 \\
\hline Gemengd & 41 & 59 \\
\hline Kaderberoepsgericht & 70 & 30 \\
\hline Basisberoepsgericht & 67 & 33 \\
\hline \multicolumn{3}{|l|}{ Naar sector } \\
\hline Landbouw & 63 & 37 \\
\hline Techniek & 77 & 23 \\
\hline Economie & 53 & 47 \\
\hline Gezondheidszorg & 60 & 40 \\
\hline Intersectoraal & 52 & 48 \\
\hline MBO & 75 & 25 \\
\hline $\mathrm{BOL}$ & 71 & 29 \\
\hline BOL niveau 1 & 67 & 33 \\
\hline BOL niveau 2 & 62 & 38 \\
\hline Landbouw & 71 & 29 \\
\hline Techniek & 66 & 34 \\
\hline Economie & 55 & 45 \\
\hline Gezondheidszorg & 66 & 34 \\
\hline BOL niveau 3 & 73 & 27 \\
\hline Landbouw & 57 & 43 \\
\hline Techniek & 85 & 15 \\
\hline Economie & 62 & 38 \\
\hline Gezondheidszorg & 87 & 13 \\
\hline Gedrag en maatschappij & 70 & 30 \\
\hline BOL niveau 4 & 74 & 26 \\
\hline Landbouw & 64 & 36 \\
\hline Techniek & 73 & 27 \\
\hline Economie & 65 & 35 \\
\hline Gezondheidszorg & 89 & 11 \\
\hline Gedrag en maatschappij & 77 & 23 \\
\hline
\end{tabular}




\section{Tabel 21}

Vereiste opleidingsrichting voor de huidige functie volgens de werkgever

\begin{tabular}{|c|c|c|}
\hline Opleidingssector & $\begin{array}{r}\text { eigen/verwante } \\
\text { richting } \\
\%\end{array}$ & $\begin{array}{r}\text { geen/andere } \\
\text { richting } \\
\%\end{array}$ \\
\hline $\mathrm{BBL}$ & 78 & 22 \\
\hline BBL niveau 1 & 46 & 54 \\
\hline BBL niveau 2 & 73 & 27 \\
\hline Landbouw & 64 & 36 \\
\hline Techniek & 73 & 27 \\
\hline Economie & 65 & 35 \\
\hline Gezondheidszorg & 84 & 16 \\
\hline BBL niveau 3 & 85 & 15 \\
\hline Landbouw & 76 & 24 \\
\hline Techniek & 86 & 14 \\
\hline Economie & 80 & 20 \\
\hline Gezondheidszorg & 92 & 8 \\
\hline Gedrag en maatschappij & 87 & 13 \\
\hline BBL niveau 4 & 90 & 10 \\
\hline Landbouw & - & - \\
\hline Techniek & 92 & 8 \\
\hline Economie & 87 & 13 \\
\hline Gezondheidszorg & 94 & 6 \\
\hline Gedrag en maatschappij & 88 & 12 \\
\hline HBO & 78 & 22 \\
\hline Landbouw & 72 & 28 \\
\hline Onderwijs & 92 & 8 \\
\hline Techniek & 85 & 15 \\
\hline Economie & 66 & 34 \\
\hline Gezondheidszorg & 91 & 9 \\
\hline Gedrag en maatschappij & 83 & 17 \\
\hline Taal en cultuur & 63 & 37 \\
\hline Totaal & 74 & 26 \\
\hline
\end{tabular}

- te weinig waarnemingen

Bron: ROA (SIS)

\section{Toelichting}

Vraag in de enquête:

Welke opleidingsrichting werd door uw werkgever voor deze functie vereist? 
Tabel 22

Oordeel van de werkende schoolverlaters over de aansluiting tussen de afgesloten opleiding en de huidige functie

\begin{tabular}{|c|c|c|c|c|}
\hline Opleidingssector & $\begin{array}{r}\text { goed } \\
\%\end{array}$ & $\begin{array}{r}\text { voldoende } \\
\%\end{array}$ & $\begin{array}{r}\text { matig } \\
\%\end{array}$ & $\begin{array}{r}\text { slecht } \\
\%\end{array}$ \\
\hline VMBO & 26 & 49 & 18 & 7 \\
\hline \multicolumn{5}{|l|}{ Naar leerweg } \\
\hline Theoretisch & 18 & 44 & 19 & 19 \\
\hline Gemengd & 22 & 48 & 23 & 7 \\
\hline Kaderberoepsgericht & 28 & 50 & 17 & 5 \\
\hline Basisberoepsgericht & 28 & 50 & 18 & 4 \\
\hline \multicolumn{5}{|l|}{ Naar sector } \\
\hline Landbouw & 34 & 41 & 19 & 7 \\
\hline Techniek & 24 & 52 & 21 & 3 \\
\hline Economie & 37 & 50 & 9 & 4 \\
\hline Gezondheidszorg & 27 & 51 & 17 & 6 \\
\hline Intersectoraal & 13 & 44 & 30 & 13 \\
\hline MBO & 37 & 43 & 13 & 8 \\
\hline $\mathrm{BOL}$ & 31 & 44 & 15 & 11 \\
\hline BOL niveau 1 & 35 & 43 & 19 & 3 \\
\hline BOL niveau 2 & 29 & 45 & 15 & 10 \\
\hline Landbouw & 23 & 59 & 9 & 9 \\
\hline Techniek & 23 & 45 & 20 & 11 \\
\hline Economie & 33 & 43 & 14 & 10 \\
\hline Gezondheidszorg & 33 & 46 & 13 & 8 \\
\hline BOL niveau 3 & 35 & 42 & 12 & 12 \\
\hline Landbouw & 33 & 32 & 15 & 20 \\
\hline Techniek & 43 & 31 & 16 & 10 \\
\hline Economie & 25 & 47 & 16 & 12 \\
\hline Gezondheidszorg & 44 & 43 & 7 & 5 \\
\hline Gedrag en maatschappij & 34 & 39 & 10 & 17 \\
\hline BOL niveau 4 & 30 & 44 & 15 & 11 \\
\hline Landbouw & 32 & 35 & 13 & 19 \\
\hline Techniek & 27 & 44 & 17 & 12 \\
\hline Economie & 29 & 45 & 13 & 13 \\
\hline Gezondheidszorg & 36 & 43 & 15 & 5 \\
\hline Gedrag en maatschappij & 26 & 44 & 20 & 11 \\
\hline
\end{tabular}




\section{Tabel 22}

Oordeel van de werkende schoolverlaters over de aansluiting tussen de afgesloten opleiding en de huidige functie

\begin{tabular}{|c|c|c|c|c|}
\hline Opleidingssector & $\begin{array}{r}\text { goed } \\
\%\end{array}$ & $\begin{array}{r}\text { voldoende } \\
\%\end{array}$ & $\begin{array}{r}\text { matig } \\
\%\end{array}$ & $\begin{array}{r}\text { slecht } \\
\%\end{array}$ \\
\hline BBL & 41 & 42 & 11 & 5 \\
\hline BBL niveau 1 & 40 & 40 & 15 & 6 \\
\hline BBL niveau 2 & 41 & 43 & 10 & 6 \\
\hline Landbouw & 31 & 50 & 15 & 4 \\
\hline Techniek & 39 & 43 & 12 & 5 \\
\hline Economie & 32 & 47 & 5 & 16 \\
\hline Gezondheidszorg & 63 & 32 & 3 & 2 \\
\hline BBL niveau 3 & 45 & 39 & 12 & 5 \\
\hline Landbouw & 38 & 45 & 12 & 6 \\
\hline Techniek & 37 & 44 & 12 & 7 \\
\hline Economie & 45 & 37 & 13 & 5 \\
\hline Gezondheidszorg & 58 & 33 & 8 & 1 \\
\hline Gedrag en maatschappij & 43 & 35 & 18 & 4 \\
\hline BBL niveau 4 & 36 & 48 & 11 & 5 \\
\hline Landbouw & - & - & - & - \\
\hline Techniek & 32 & 47 & 10 & 10 \\
\hline Economie & 43 & 47 & 6 & 4 \\
\hline Gezondheidszorg & 33 & 47 & 16 & 4 \\
\hline Gedrag en maatschappij & 37 & 49 & 14 & \\
\hline HBO & 34 & 41 & 17 & 9 \\
\hline Landbouw & 26 & 41 & 19 & 14 \\
\hline Onderwijs & 49 & 36 & 9 & 6 \\
\hline Techniek & 32 & 45 & 16 & 6 \\
\hline Economie & 26 & 43 & 20 & 11 \\
\hline Gezondheidszorg & 45 & 40 & 12 & 3 \\
\hline Gedrag en maatschappij & 28 & 40 & 21 & 10 \\
\hline Taal en cultuur & 36 & 30 & 16 & 18 \\
\hline Totaal & 35 & 43 & 14 & 8 \\
\hline
\end{tabular}

- = te weinig waarnemingen

Bron: ROA (SIS)

\section{Toelichting}

Vraag in de enquête:

Hoe vindt u de aansluiting tussen uw [... . opleiding en uw huidige functie? 
Tabel 23

Beloning van werkende schoolverlaters

\begin{tabular}{|c|c|c|}
\hline Opleidingssector & $\begin{array}{r}\text { gemiddeld } \\
\text { bruto maandloon } \\
€\end{array}$ & $\begin{array}{r}\text { gemiddeld } \\
\text { bruto uurloon } \\
€\end{array}$ \\
\hline HAVO/VWO & 552 & 5,58 \\
\hline HAVO & 603 & 4,97 \\
\hline VW0 & 487 & 6,34 \\
\hline VMBO & 549 & 4,46 \\
\hline \multicolumn{3}{|l|}{ Naar leerweg } \\
\hline Theoretisch & 406 & 4,33 \\
\hline Gemengd & 578 & 4,49 \\
\hline Kaderberoepsgericht & 514 & 4,04 \\
\hline Basisberoepsgericht & 646 & 4,87 \\
\hline \multicolumn{3}{|l|}{ Naar sector } \\
\hline Landbouw & 636 & 4,98 \\
\hline Techniek & 757 & 5,00 \\
\hline Economie & 408 & 4,00 \\
\hline Gezondheidszorg & 424 & 4,14 \\
\hline Intersectoraal & 331 & 2,81 \\
\hline MBO & 1.500 & 10,73 \\
\hline BOL & 1.253 & 9,37 \\
\hline BOL niveau 1 & 943 & 7,22 \\
\hline BOL niveau 2 & 1.022 & 7,83 \\
\hline Landbouw & 822 & 5,70 \\
\hline Techniek & 1.233 & 8,05 \\
\hline Economie & 1.002 & 7,78 \\
\hline Gezondheidszorg & 825 & 7,87 \\
\hline BOL niveau 3 & 1.173 & 9,21 \\
\hline Landbouw & 813 & 6,03 \\
\hline Techniek & 1.606 & 9,58 \\
\hline Economie & 1.175 & 8,60 \\
\hline Gezondheidszorg & 1.203 & 10,12 \\
\hline Gedrag en maatschappij & 1.094 & 9,74 \\
\hline BOL niveau 4 & 1.378 & 10,03 \\
\hline Landbouw & 1.265 & 9,08 \\
\hline Techniek & 1.552 & 10,06 \\
\hline Economie & 1.321 & 9,30 \\
\hline Gezondheidszorg & 1.436 & 11,13 \\
\hline Gedrag en maatschappij & 1.193 & 10,26 \\
\hline
\end{tabular}


Tabel 23

Beloning van werkende schoolverlaters

\begin{tabular}{|c|c|c|}
\hline Opleidingssector & $\begin{array}{r}\text { gemiddeld } \\
\text { bruto maandloon } \\
€\end{array}$ & $\begin{array}{r}\text { gemiddeld } \\
\text { bruto uurloon } \\
€\end{array}$ \\
\hline$B B L$ & 1.676 & 11,70 \\
\hline BBL niveau 1 & 1.504 & 10,91 \\
\hline BBL niveau 2 & 1.558 & 10,56 \\
\hline Landbouw & 1.463 & 9,51 \\
\hline Techniek & 1.695 & 10,67 \\
\hline Economie & 1.273 & 10,04 \\
\hline Gezondheidszorg & 1.282 & 11,22 \\
\hline BBL niveau 3 & 1.734 & 12,10 \\
\hline Landbouw & 2.025 & 12,31 \\
\hline Techniek & 2.078 & 12,55 \\
\hline Economie & 1.426 & 9,65 \\
\hline Gezondheidszorg & 1.556 & 13,28 \\
\hline Gedrag en maatschappij & 1.462 & 13,18 \\
\hline BBL niveau 4 & 1.862 & 13,40 \\
\hline Landbouw & - & - \\
\hline Techniek & 2.261 & 14,17 \\
\hline Economie & 1.608 & 11,57 \\
\hline Gezondheidszorg & 1.859 & 14,58 \\
\hline Gedrag en maatschappij & 1.748 & 13,67 \\
\hline HBO & 1.941 & 13,28 \\
\hline Landbouw & 1.996 & 13,16 \\
\hline Onderwijs & 1.784 & 13,60 \\
\hline Techniek & 2.346 & 14,13 \\
\hline Economie & 2.064 & 12,99 \\
\hline Gezondheidszorg & 1.998 & 15,10 \\
\hline Gedrag en maatschappij & 1.638 & 13,15 \\
\hline Taal en cultuur & 1.280 & 9,65 \\
\hline Totaal & 1.484 & 10,56 \\
\hline
\end{tabular}

- = te weinig waarnemingen

Bron: ROA (SIS)

\section{Toelichting}

Dit betreft het bruto inkomen in de hoofdfunctie. Dit is inclusief toeslagen maar exclusief inkomen uit overwerk. Er is hier niet gecorrigeerd voor verschillen in leeftijd van de schoolverlaters. 
Tabel 24

Tevredenheid met huidige functie

\begin{tabular}{|c|c|}
\hline Opleidingssector & $\%$ \\
\hline VMBO & 76 \\
\hline \multicolumn{2}{|l|}{ Naar leerweg } \\
\hline Theoretisch & 86 \\
\hline Gemengd & 90 \\
\hline Kaderberoepsgericht & 74 \\
\hline Basisberoepsgericht & 70 \\
\hline \multicolumn{2}{|l|}{ Naar sector } \\
\hline Landbouw & 89 \\
\hline Techniek & 68 \\
\hline Economie & 62 \\
\hline Gezondheidszorg & 93 \\
\hline Intersectoraal & 68 \\
\hline MBO & 69 \\
\hline BOL & 69 \\
\hline BOL niveau 1 & 56 \\
\hline BOL niveau 2 & 67 \\
\hline Landbouw & 81 \\
\hline Techniek & 60 \\
\hline Economie & 64 \\
\hline Gezondheidszorg & 76 \\
\hline BOL niveau 3 & 70 \\
\hline Landbouw & 51 \\
\hline Techniek & 72 \\
\hline Economie & 67 \\
\hline Gezondheidszorg & 76 \\
\hline Gedrag en maatschappij & 69 \\
\hline BOL niveau 4 & 70 \\
\hline Landbouw & 71 \\
\hline Techniek & 72 \\
\hline Economie & 67 \\
\hline Gezondheidszorg & 76 \\
\hline Gedrag en maatschappij & 66 \\
\hline
\end{tabular}




\section{Tabel 24}

Tevredenheid met huidige functie

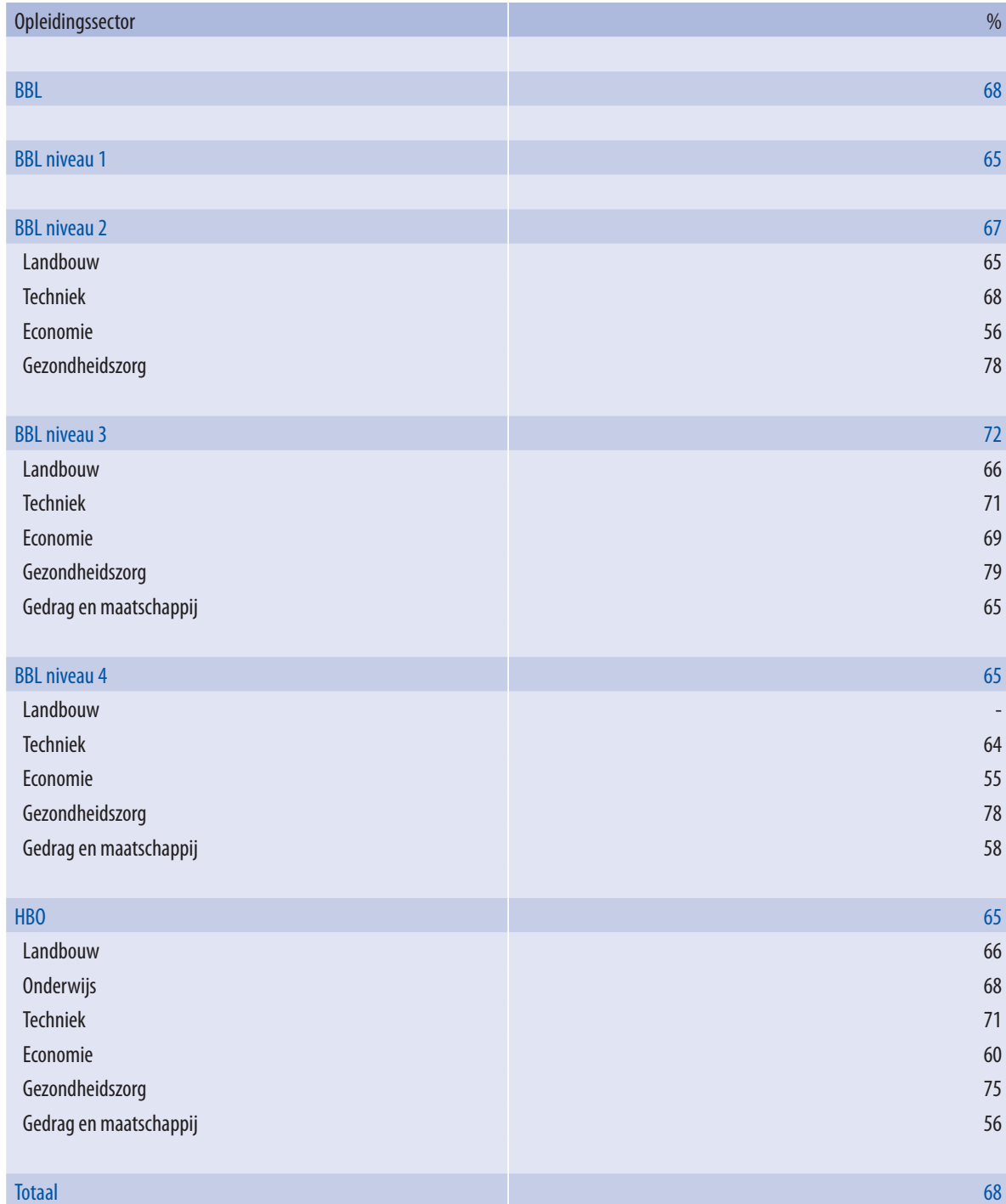

- = te weinig waarnemingen

Bron: ROA (SIS)

\section{Toelichting}

Vraag in de enquête:

Hoe tevreden bent u met uw huidige functie ( 1 'zeer ontevreden' tot en met 5 'zeer tevreden'). Vermeld is het percentage van antwoordcategorie 4 en 5 . 
Tabel 25

Percentage werkende schoolverlaters waarvan huidige functie goede carrièreperspectieven biedt

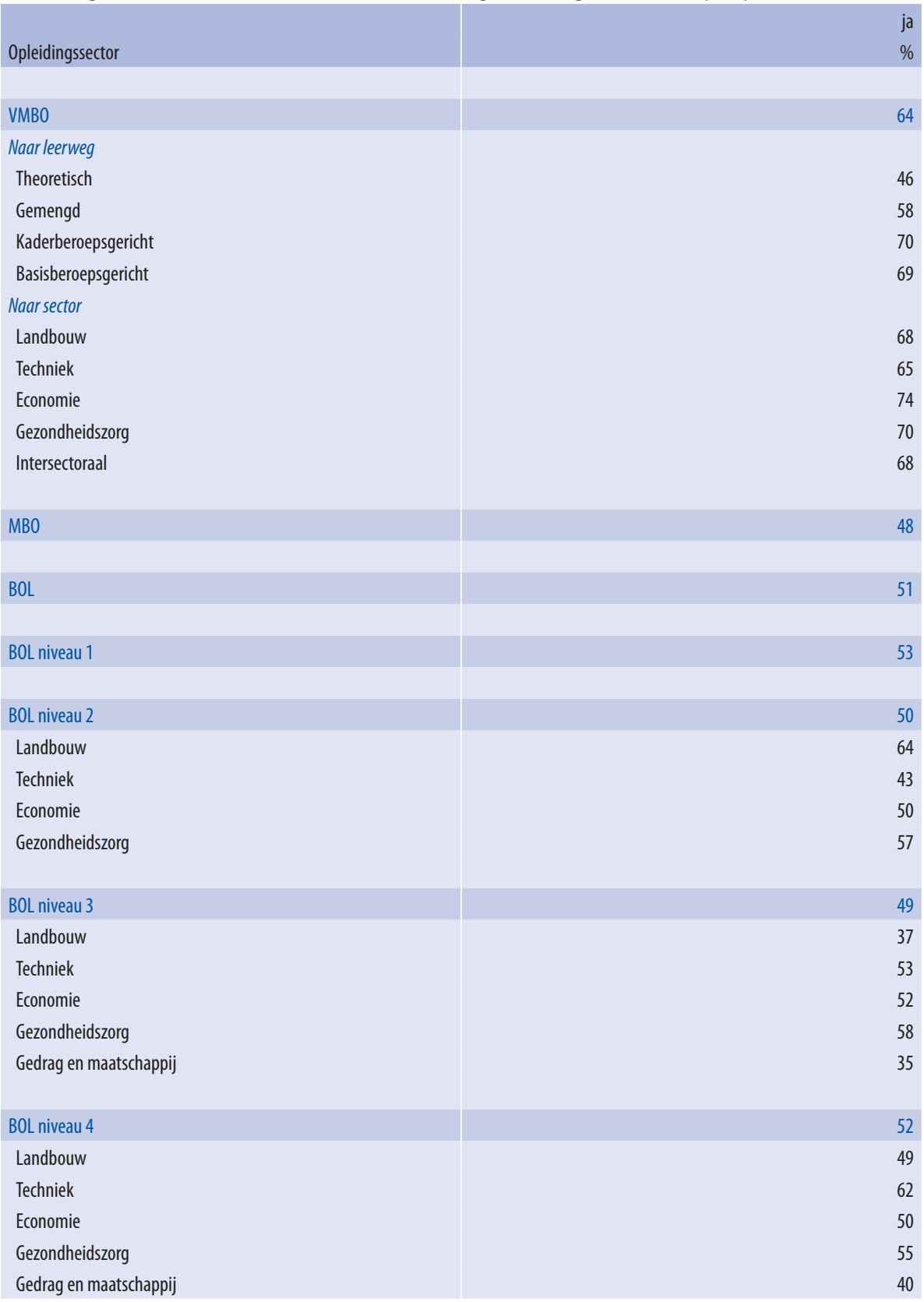




\section{Tabel 25}

Percentage werkende schoolverlaters waarvan huidige functie goede carrièreperspectieven biedt

$\begin{array}{ll} & \text { ja } \\ \text { Opleidingssector } & \%\end{array}$

BBL

BBL niveau 1

BBL niveau 2

Landbouw

Techniek

Economie

Gezondheidszorg

BBL niveau 3

Landbouw

Techniek

Economie

Gezondheidszorg

Gedrag en maatschappij

BBL niveau 4

Landbouw

Techniek

Economie

Gedrag en maatschappij

HBO

Landbouw

Techniek

Economie

Gezondheidszorg

Totaal

- = te weinig waarnemingen

Bron: ROA (SIS)

\section{Toelichting}

Vraag in de enquête:

Biedt uw functie goede carrièremogelijkheden? (1'nauwelijks' tot en met 5 'heel veel'). Vermeld is het percentage van antwoordcategorie 4 en 5. 
Tabel 26

Benutting van kennis en vaardigheden en kennis en vaardigheden schieten tekort volgens oordeel werkende schoolverlaters

\begin{tabular}{|c|c|c|}
\hline Opleidingssector & $\begin{array}{r}\text { Benutting kennis en vaardigheden } \\
\text { ja } \\
\%\end{array}$ & $\begin{array}{r}\text { Kennis en vaardigheden schieten tekort } \\
\text { ja } \\
\%\end{array}$ \\
\hline VMBO & 60 & 13 \\
\hline \multicolumn{3}{|l|}{ Naar leerweg } \\
\hline Theoretisch & 46 & 3 \\
\hline Gemengd & 72 & 5 \\
\hline Kaderberoepsgericht & 68 & 16 \\
\hline Basisberoepsgericht & 58 & 17 \\
\hline \multicolumn{3}{|l|}{ Naar sector } \\
\hline Landbouw & 61 & 7 \\
\hline Techniek & 70 & 24 \\
\hline Economie & 63 & 7 \\
\hline Gezondheidszorg & 54 & 9 \\
\hline Intersectoraal & 53 & 12 \\
\hline MBO & 63 & 10 \\
\hline BOL & 62 & 12 \\
\hline B0L niveau 1 & 53 & 19 \\
\hline BOL niveau 2 & 60 & 16 \\
\hline Landbouw & 45 & 14 \\
\hline Techniek & 49 & 11 \\
\hline Economie & 62 & 19 \\
\hline Gezondheidszorg & 75 & 18 \\
\hline BOL niveau 3 & 61 & 12 \\
\hline Landbouw & 55 & 10 \\
\hline Techniek & 62 & 13 \\
\hline Economie & 55 & 9 \\
\hline Gezondheidszorg & 74 & 14 \\
\hline Gedrag en maatschappij & 57 & 14 \\
\hline BOL niveau 4 & 63 & 11 \\
\hline Landbouw & 65 & 16 \\
\hline Techniek & 57 & 8 \\
\hline Economie & 55 & 13 \\
\hline Gezondheidszorg & 77 & 13 \\
\hline Gedrag en maatschappij & 64 & 7 \\
\hline
\end{tabular}




\section{Tabel 26}

Benutting van kennis en vaardigheden en kennis en vaardigheden schieten tekort volgens oordeel werkende schoolverlaters

\begin{tabular}{|c|c|c|}
\hline Opleidingssector & $\begin{array}{r}\text { Benutting kennis en vaardigheden } \\
\mathrm{ja} \\
\%\end{array}$ & $\begin{array}{r}\text { Kennis en vaardigheden schieten tekort } \\
\text { ja } \\
\%\end{array}$ \\
\hline BBL & 65 & 8 \\
\hline BBL niveau 1 & 55 & 14 \\
\hline BBL niveau 2 & 60 & 7 \\
\hline Landbouw & 55 & 9 \\
\hline Techniek & 63 & 7 \\
\hline Economie & 36 & 2 \\
\hline Gezondheidszorg & 82 & 17 \\
\hline BBL niveau 3 & 68 & 7 \\
\hline Landbouw & 65 & 9 \\
\hline Techniek & 63 & 6 \\
\hline Economie & 59 & 6 \\
\hline Gezondheidszorg & 82 & 9 \\
\hline Gedrag en maatschappij & 74 & 9 \\
\hline BBL niveau 4 & 71 & 9 \\
\hline Landbouw & - & - \\
\hline Techniek & 62 & 7 \\
\hline Economie & 74 & 9 \\
\hline Gezondheidszorg & 76 & 11 \\
\hline Gedrag en maatschappij & 70 & 2 \\
\hline HBO & 62 & 6 \\
\hline Landbouw & 57 & 4 \\
\hline Onderwijs & 79 & 7 \\
\hline Techniek & 64 & 6 \\
\hline Economie & 52 & 6 \\
\hline Gezondheidszorg & 77 & 7 \\
\hline Gedrag en maatschappij & 53 & 7 \\
\hline Totaal & 63 & 9 \\
\hline
\end{tabular}

- te weinig waarnemingen

Bron: ROA (SIS)

\section{Toelichting}

Vragen in de enquête:

In welke mate worden in uw huidige functie uw kennis en vaardigheden benut ( 1 'helemaal niet' tot en met 5 'in sterke mate'). Vermeld is het percentage van antwoordcategorie 4 en 5.

In welke mate schieten uw kennis en vaardigheden tekort voor uw huidige functie ( 1 'helemaal niet' tot en met 5 'in sterke mate')? Vermeld is het percentage van antwoordcategorie 4 en 5. 


\section{Tabel 27}

Percentage werkende schoolverlaters dat op zoek is naar een andere baan

\begin{tabular}{|c|c|}
\hline Opleidingssector & $\%$ \\
\hline HAVO/VWO & 4 \\
\hline HAVO & 7 \\
\hline VMBO & 10 \\
\hline Naarleerweg & \\
\hline Theoretisch & 18 \\
\hline Gemengd & 12 \\
\hline Kaderberoepsgericht & 5 \\
\hline Basisberoepsgericht & 9 \\
\hline Naar sector & \\
\hline Landbouw & 10 \\
\hline Techniek & 9 \\
\hline Economie & 0 \\
\hline Gezondheidszorg & 9 \\
\hline Intersectoraal & 11 \\
\hline MBO & 12 \\
\hline BOL & 17 \\
\hline BOL niveau 1 & 11 \\
\hline BOL niveau 2 & 16 \\
\hline Techniek & 11 \\
\hline Economie & 22 \\
\hline Gezondheidszorg & 14 \\
\hline BOL niveau 3 & 19 \\
\hline Landbouw & 13 \\
\hline Techniek & 15 \\
\hline Economie & 24 \\
\hline Gezondheidszorg & 9 \\
\hline Gedrag en maatschappij & 27 \\
\hline BOL niveau 4 & 16 \\
\hline Landbouw & 20 \\
\hline Techniek & 14 \\
\hline Economie & 16 \\
\hline Gezondheidszorg & 15 \\
\hline Gedrag en maatschappij & 22 \\
\hline
\end{tabular}




\section{Tabel 27}

Percentage werkende schoolverlaters dat op zoek is naar een andere baan

\begin{tabular}{|c|c|}
\hline Opleidingssector & $\%$ \\
\hline BBL & 10 \\
\hline BBL niveau 1 & 11 \\
\hline BBL niveau 2 & 10 \\
\hline Landbouw & 4 \\
\hline Techniek & 9 \\
\hline Economie & 14 \\
\hline Gezondheidszorg & 7 \\
\hline BBL niveau 3 & 8 \\
\hline Landbouw & 11 \\
\hline Techniek & 8 \\
\hline Economie & 9 \\
\hline Gezondheidszorg & 7 \\
\hline Gedrag en maatschappij & 12 \\
\hline BBL niveau 4 & 11 \\
\hline Landbouw & - \\
\hline Techniek & 12 \\
\hline Economie & 11 \\
\hline Gezondheidszorg & 10 \\
\hline Gedrag en maatschappij & 16 \\
\hline HBO & 26 \\
\hline Landbouw & 24 \\
\hline Onderwijs & 26 \\
\hline Techniek & 14 \\
\hline Economie & 26 \\
\hline Gezondheidszorg & 16 \\
\hline Gedrag en maatschappij & 35 \\
\hline Taal en cultuur & 52 \\
\hline Totaal & 15 \\
\hline
\end{tabular}

- = te weinig waarnemingen

Bron: ROA (SIS) 


\section{Tabel 28}

Opleiding achteraf opnieuw kiezen

\begin{tabular}{|c|c|c|}
\hline Opleidingssector & zelfde opleiding \% & andere opleiding \% \\
\hline HAVO/VWO & 97 & 3 \\
\hline HAVO & 96 & 4 \\
\hline VWO & 98 & 2 \\
\hline VMBO & 87 & 13 \\
\hline \multicolumn{3}{|l|}{ Naar leerweg } \\
\hline Theoretisch & 87 & 13 \\
\hline Gemengd & 93 & 7 \\
\hline Kaderberoepsgericht & 89 & 11 \\
\hline Basisberoepsgericht & 82 & 18 \\
\hline \multicolumn{3}{|l|}{ Naar sector } \\
\hline Landbouw & 85 & 15 \\
\hline Techniek & 88 & 12 \\
\hline Economie & 84 & 16 \\
\hline Gezondheidszorg & 90 & 10 \\
\hline Intersectoraal & 90 & 10 \\
\hline MBO & 80 & 20 \\
\hline BOL & 77 & 23 \\
\hline BOL niveau 1 & 80 & 20 \\
\hline BOL niveau 2 & 77 & 23 \\
\hline Landbouw & 72 & 28 \\
\hline Techniek & 83 & 17 \\
\hline Economie & 71 & 29 \\
\hline Gezondheidszorg & 79 & 21 \\
\hline BOL niveau 3 & 76 & 24 \\
\hline Landbouw & 74 & 26 \\
\hline Techniek & 77 & 23 \\
\hline Economie & 70 & 30 \\
\hline Gezondheidszorg & 88 & 12 \\
\hline Gedrag en maatschappij & 73 & 27 \\
\hline BOL niveau 4 & 77 & 23 \\
\hline Landbouw & 73 & 27 \\
\hline Techniek & 77 & 23 \\
\hline Economie & 76 & 24 \\
\hline Gezondheidszorg & 81 & 19 \\
\hline Gedrag en maatschappij & 78 & 22 \\
\hline
\end{tabular}




\section{Tabel 28}

Opleiding achteraf opnieuw kiezen

\begin{tabular}{|c|c|c|}
\hline Opleidingssector & zelfde opleiding \% & andere opleiding \% \\
\hline BBL & 84 & 16 \\
\hline BBL niveau 1 & 83 & 17 \\
\hline BBL niveau 2 & 85 & 15 \\
\hline Landbouw & 86 & 14 \\
\hline Techniek & 87 & 13 \\
\hline Economie & 79 & 21 \\
\hline Gezondheidszorg & 82 & 18 \\
\hline BBL niveau 3 & 84 & 16 \\
\hline Landbouw & 80 & 20 \\
\hline Techniek & 85 & 15 \\
\hline Economie & 78 & 22 \\
\hline Gezondheidszorg & 89 & 11 \\
\hline Gedrag en maatschappij & 81 & 19 \\
\hline BBL niveau 4 & 86 & 14 \\
\hline Landbouw & - & - \\
\hline Techniek & 92 & 8 \\
\hline Economie & 82 & 18 \\
\hline Gezondheidszorg & 86 & 14 \\
\hline Gedrag en maatschappij & 82 & 18 \\
\hline HBO & 79 & 21 \\
\hline Landbouw & 74 & 26 \\
\hline Onderwijs & 86 & 14 \\
\hline Techniek & 85 & 15 \\
\hline Economie & 73 & 27 \\
\hline Gezondheidszorg & 86 & 14 \\
\hline Gedrag en maatschappij & 76 & 24 \\
\hline Taal en cultuur & 85 & 15 \\
\hline Totaal & 85 & 15 \\
\hline
\end{tabular}

- te weinig waarnemingen

Bron: ROA (SIS) 